\title{
Systematics of the Neotropical fish subfamily Glandulocaudinae (Teleostei: Characiformes: Characidae)
}

\author{
Naércio A. Menezes ${ }^{1}$ and Stanley H. Weitzman²
}

The systematics of the Glandulocaudinae is reviewed in detail and justification for the recognition of the group as a subfamily is discussed. The subfamily Glandulocaudinae consists of three genera: Lophiobrycon with one species plesiomorphic in some anatomical features but some others exclusively derived relative to the species in the other genera; Glandulocauda with two species intermediate in phylogenetic derivation; and Mimagoniates with seven species (one new), all more phylogenetically derived concerning their pheromone producing caudal-fin organs and with other anatomical characters presumably more derived than in the species of the other genera. Glandulocauda melanogenys Eigenmann, 1911, is considered a junior synonym of Hyphessobrycon melanopleurus Ellis, 1911. A replacement name, Glandulocauda caerulea Menezes \& Weitzman, is proposed for G. melanopleura Eigenmann, 1911. Gland cells found in the caudal-fin organs of all species are histologically indistinguishable from club cells and probably secrete a pheromone during courtship. The club cells are associated with somewhat modified to highly derived caudal scales forming a pheromone pumping organ in the more derived genera and species. This subfamily is distributed in freshwaters of eastern and southern Brazil, Paraguay, and northeastern Uruguay.

A sistemática de Glandulocaudinae é revista e a justificativa para o reconhecimento do grupo como subfamília discutida. A subfamília Glandulocaudinae consiste de três gêneros: Lophiobrycon, com uma espécie plesiomórfica com relação a alguns caracteres anatômicos, mas outros derivados e exclusivos em relação às espécies dos outros dois gêneros; Glandulocauda, com duas espécies intermediárias quanto à condição dos caracteres derivados; e Mimagoniates, com sete espécies (uma nova), todas filogeneticamente mais avançadas quanto às características dos órgãos da nadadeira caudal produtores de feromônio e outras características anatômicas presumivelmente mais derivadas do que nas espécies dos outros gêneros. Glandulocauda melanogenys Eigenmann, 1911, é considerado sinônimo junior de Hyphessobrycon melanopleurus Ellis, 1911. O nome Glandulocauda caerulea Menezes \& Weitzman, é proposto em substiutição para G. melanopleura Eigenmann, 1911. Células glandulares encontradas nos órgãos da caudal são histologicamente indistinguíveis de "células club" e provavelmente secretam algum tipo de feromônio durante a corte. As "células club” são associadas a escamas da caudal pouco ou inteiramente modificadas e fazendo parte dos órgãos bombeadores de feromônio nas espécies e gêneros mais derivados. Esta subfamília distribui-se em ambientes de água doce do leste e sul do Brasil, no Paraguai e nordeste do Uruguai.

Key words: South America, Lophiobrycon, Glandulocauda, Mimagoniates, Taxonomy, Biogeography.

\section{Introduction}

The species of the Glandulocaudinae are distributed in parts of eastern and southern Brazil, Paraguay, and northeastern Uruguay. They are all attractively colored, relatively small fishes, usually about $28-60 \mathrm{~mm}$ in standard length as adults. None qualify as miniatures as defined by Weitzman \& Vari (1988: 450), even though some species begin maturation at the relatively small size of about $24 \mathrm{~mm}$ in standard length. Some of the ten species of the subfamily are apparently adapted to narrowly restricted habitats, and limited in distribution by ecology. Some species may be threatened with extinction and one may already be extinct due to relatively recent habitat alterations, primarily deforestation, by man. We comment on these problems in the species accounts and summarize them in a general section on conservation and ecology of the species of the subfamily.

The subfamily Glandulocaudinae Eigenmann (1914) as recognized by Weitzman \& Menezes (1998: 171) and Weitzman (2003: 222) was discussed by Weitzman et al. (2005: 332-333)

\footnotetext{
${ }^{1}$ Museu de Zoologia, Universidade de São Paulo, Caixa Postal 42494, 04218-970 São Paulo, SP, Brazil. naercio@usp.br 2Smithsonian Institution, Division of Fishes, MRC 159, PO Box 37012 Washington DC, 20013-7102, USA. weitzmans@si.edu
} 
and split into two inseminating characid subfamilies, the Glandulocaudinae and Stevardiinae Gill (1858). The reasons for Weitzman et al. (2005) decision were based on new evidence for a somewhat different phylogenetic arrangement related to the recognition of inseminating and noninseminating Clade A characids of Malabarba \& Weitzman (2003). In part Weitzman et al. (2005) utilized the very different comparative developmental and mature male caudal-fin organ gross anatomies that separate the Glandulocaudinae and Stevardiinae as initially outlined in a discussion and key to the species of the then recognized tribe Glandulocaudini (Menezes \& Weitzman, 1990: 380-387). Weitzman et al. (2005: 344) also noted that the glandular cells of the male caudal organs of these two subfamilies are entirely different. In the Glandulocaudinae they are histologically indistinguishable from club cells (alarm substance cells) whereas they and consist of modified mucous cells in the Stevardiinae. From this it appears that the Glandulocaudinae and Stevardiinae may have evolved independently from inseminating Clade A characids that lack male caudal organs. Here we further outline the differences in the derived caudal organs of these two Clade A characid subfamilies. Mirande (2009) based exclusively on the analysis of osteological characters introduced all the members of clade A characids including the Glandulocaudinae as subgroups of a large subfamily named Stevardiinae. Since he did not use in his analysis insemination, histological structures of caudal organs and of gonads we think the classification he proposed is not consistent with all the morphological evidences currently available for the characid groups involved and is not herein accepted.

The subfamily Glandulocaudinae (= the Glandulocaudini of Menezes \& Weitzman, 1990) consists of three genera, Lophiobrycon Castro et al. (2003: 13) with one species, Glandulocauda Eigenmann (1911b: 168) with two species, and Mimagoniates Regan (1907: 402) with seven species. Lophiobrycon weitzmani Castro, Ribeiro, Benine \& Melo (2003) was assigned by its authors as a basal species related to all others within the Glandulocaudini of the former Glandulocaudinae.

The Glandulocaudinae of this study was diagnosed by Weitzman \& Menezes (1998: 183) as a tribe, Glandulocaudini. All species of the Glandulocaudinae have various forms of a male caudal-fin organ that apparently secretes one or more pheromones during courtship. In the more basal species in Lophiobrycon and Glandulocauda this organ consists of beaded lines of glandular tissue consisting of club cells at the surface of the skin arranged along parts of the middle and some of the ventral caudal-fin rays. In the species, of Mimagoniates, in the most distal branches of the phylogeny the glandular tissue, along the modified fin rays forms part of a pumping organ consisting of modified caudal-fin rays and modified caudal-fin scales derived from the dorsal caudal-fin lobe. Presumably this organ in association with tail beating propels pheromones towards the females' head during courtship. See Nelson (1964a, 1964b, 1964c) for detailed observations and discussions of courtship in the
Glandulocaudinae and Stevardiinae.

Many previous authors dealing with systematics of the Glandulocaudinae had to face many difficulties not only related to the poor preservation of type-specimens, but also to non-availability in collections of mature male specimens active at time of preservation. Thus few phylogenetically informative information is available. Here we provide phylogenetic data about the subfamily in an attempt to explain our nomenclatural decisions based on our hypothesis of the phylogeny of these fishes.

The phylogeny presented here is mostly based on an analysis of primary and especially secondary sexual characters of the males and recent collections were necessary to address many of the phylogenetic issues. When utilizing primary and secondary sexual characters of glandulocaudine fishes for phylogenetic studies, it is absolutely necessary to examine fully sexually active mature males because the males of the more distally located species in the cladogram have their caudal organ and its accompanying osteological structures in a less complex state during earlier stages of maturation and sexual maturity. These stages in these species are similar to those of fully adult males of more basal species, a serious source of confusion regarding identification and employment of these features for phylogenetic study. The only way to recognize that males of a given population sample have fully adult secondary sexual characteristics is to examine males with fully active testes. Even then, it appears that some males acquire active testes before the caudal organ reaches full development.

\section{Material and Methods}

Counts and measurements follow Fink \& Weitzman (1974: 1-2) and Menezes \& Weitzman (1990: 382-383). For counts recorded in the descriptions, the range is given first followed in parentheses by counts of the holotype, the mean, and total number of specimens counted. Total vertebral counts include the four vertebrae of the Weberian apparatus complex. The terminal "half centrum" hypural bones and associated vertebral elements, usually designated as PU1+U1, but not necessarily consisting only of those elements were counted as one vertebral element. Vertebral counts were taken from radiographs and from cleared alizarin red and alcian blue stained preparations. These preparations are called "cleared and stained" in the text or abbreviated c\&s in lists of specimens.

All measurements other than standard length (SL) are expressed as percentage of SL except for subunits of the head that are recorded as percentage of head length. When using the t-test to estimate significance of mean differences between males and females a difference was considered significant when $\mathrm{p} \leq 0.05$. In the key, statistical parameters such as ranges and means are for all of the specimens of a species in which the character was examined. In statistical tests for comparisons of species, the data were limited to samples from a particular locality or from adjacent localities unless otherwise stated. Data were, in designated instances, taken from all available specimens from which a given character 
could be recorded. In statistical tests for intra-specific comparisons and for the presentation of statistical parameters of more restricted population samples, the data were limited to samples from a particular locality or to adjacent localities that were geographically and hydrologically so close to each other (for example all from the same relatively small stream basin) that we assumed the specimens could be considered to be from one genetically continuous population sample.

We have been selective in our examination of samples in species with a wide geographic distributions represented in our samples by many lots from a variety of relatively isolated geographic locations. Such widely distributed species may require future studies in order to measure variation and differences among geographically separated populations.

Basic descriptive statistics and statistical tests of null hypotheses of character similarities, scatter plots and their regression lines and the lines representing were computed using SigmaPlot 9.0 (2004), and SigmaStat 3.1 for Windows (2004), Systat Software, Inc. and are described in Weitzman \& Malabarba (1999).

Graphs or tables presenting the mean, standard deviation or the $95 \%$ confidence intervals, standardly presented in systematic research, often poorly represent the structure of nonparametric data sets and thus may be misleading. To better reflect the structure of non-normal data sets we use comparative box plots of meristic data. We suggest that graphs comparing such plots are useful for identifying clines of data from a series of isolated populations that are geographically arranged in a linear fashion, for example see our treatment of the series of geographically adjacent populations of Mimagoniates microlepis. Comparative graphs of nonparametric meristic data sets, represented by Tukey box plots of ranked data, were prepared from combined population samples of each species, and for M. microlepis, for certain geographically isolated population samples. These graphs comparatively display ranked data sets as Tukey box plots laid on their sides so that geographical and/or other information could be included. The methods are explained in Weitzman \& Malabarba (1999).

The entire population sample for each morphometric character is shown on the linear plots to show the growth curves for characters that are either sexually dimorphic or differ among the species of Mimagoniates. Tests of differences in morphometric features between the sexes of a given species were done using regression analyses only on members of both sexes that had a comparable range of standard lengths. Regression lines, should not be constructed as predictors of body shape beyond the data in the relevant plots. Regression statistics are based on the linear regression model. In regression analyses a series of diagnostic estimates of parameters were routinely run to determine the suitability of the data for the linear regression model.

The synonymies are not meant to be complete. We have attempted exhaustive citations only to the ichthyological literature, except for catalogs of genera. We have included the catalogs of Travassos (1951a, 1951b, 1952), and Eschmeyer (1990) who in turn cite other earlier catalogs of genera. We cite only historically important aquarium references and those that have bearing on nomenclature.

Comments on phylogeny are based on the concepts of phylogenetic systematics of Hennig (1966) as reviewed and discussed by Wiley (1981). Maddison et al. (1984) are followed for outgroup considerations. Biogeographic principles follow Humphries \& Parenti (1986).

Polarity hypotheses for characters and recognition of transformation series were based on the phylogenetic tree derived from the parsimony analysis. This analysis produced a phylogeny in which most of the secondary sexual apomorphies are arranged on the tree in order of increasing anatomical complexity and represent various apparently correlated transformation series extending up the subfamily tree to the most complex states in the most distal species in the cladogram. Information regarding tree formation used PAUP 3.1.1, Swofford (1993).

With respect to the condition branched versus unbranched of the anterior pelvic-fin ray we feel that in spite of the very small specimens of some species included in the clade encompassing Glandulocauda and Mimagoniates not having the branched condition of the adults does not alter the unique nature of this feature at the level of the phylogeny of the Glandulocaudinae. For this reason character state was not coded as polymorphic.

When necessary our occasional use of generic names for various stevardiine subgroups is inevitably partly subjective and based on a conservative use of the available names within the limitations imposed on the process by stevardiine phylogenetic relationships discussed by Weitzman \& Menezes (1998) and Weitzman et al. (2005). All photographs of fishes are from preserved specimens unless otherwise noted.

The following abbreviations are used for institutions and collections. AMNH - American Museum of Natural History, New York; ANSP - Academy of Natural Sciences of Philadelphia; BMNH - The Natural History Museum, London; FMNH - Field Museum of Natural History, Chicago; FUA - Fundação Universidade do Amazonas, Manaus; FURG - Fundação Universidade de Rio Grande, Rio Grande; LIRP - Laboratório de Ictiologia, Faculdade de Filosofia, Ciências e Letras de Ribeirão Preto, Universidade de São Paulo, Ribeirão Preto; MAPA - Museu Anchieta, Porto Alegre; MCP - Museu de Ciências e Tecnologia da Pontifícia Universidade Católica do Rio Grande do Sul, Porto Alegre; MNRJ - Museu Nacional, Rio de Janeiro; MZUSP - Museu de Zoologia da Universidade de São Paulo, São Paulo; NMW - Naturhistorisches Museum Wien; UFPB - Universidade Federal da Paraíba, João Pessoa; UFRGS - Universidade Federal do Rio Grande do Sul, Porto Alegre; UFRRJ - Universidade Federal Rural do Rio de Janeiro, Rio de Janeiro; UFSC - Universidade Federal de São Carlos, São Carlos; UMMZ - University of Michigan Museum of Zoology, Ann Arbor; USNM - National Museum of Natural History, Smithsonian Institution, Washington D.C. Other abbreviations are as follows: HL - Head Length; km - kilometers; LL - lateral line; HL - Head Length; mm - millimeters; SL standard length; spm(s) - specimen(s). 


\section{Results}

As briefly discussed by Weitzman et al. (2005: 345) the Glandulocaudinae defined in this paper corresponds to the Glandulocaudini of Menezes \& Weitzman (1990) and may have evolved independently of the Stevardiinae from a Knoduslike ancestor based on their different morphology. Both subfamilies belong to Clade A characids.

Weitzman et al. (2005) reported that the four proposed glandulocaudine synapomorphies listed by Weitzman \& Menezes (1998) are also present in some, but not all members of the genus Knodus Eigenmann. Knodus is similar to and placed in the synonymy of Bryconamericus Eigenmann by some authors (see discussion in Lima et al., 2004), consisting of Clade A characids without a caudal gland, but with a series of scales extended onto the caudal fin. A slight modification of the cladogram hypothesizing relationships within Clade A characids (Weitzman et al., 2005, fig. 11) is shown in Fig. 1. It indicates that Glandulocaudinae falls within the group of inseminating Clade A characids.

\section{Glandulocaudine Phylogeny}

A preliminary cladogram showing relationships within the Glandulocaudinae was published in Menezes et al. (2008). Analysis and polarization of the characters in all glandulocaudine genera and species as well as outgroups discussed below reveals a slightly different picture with respect to sister-group relationships of Mimagoniates species (compare fig. 2 of Menezes et al., 2008 with Fig. 2 herein included). The analysis was based on 14 characters and ten species of the three glandulocaudine genera. The matrix is presented in Table 1. The multistate characters were run ordered. A single tree with 19 steps was obtained. Since our primary purpose is just to show the relationships among the genera and species of the Glandulocaudinae, we chose as outgroups the genera considered to be non-inseminating Clade A characids, other inseminating Clade A characids and the Stevardiinae. We presume that insemination is a derived feature within Clade A characids and those that do not possess insemination do not share the synapomorphies

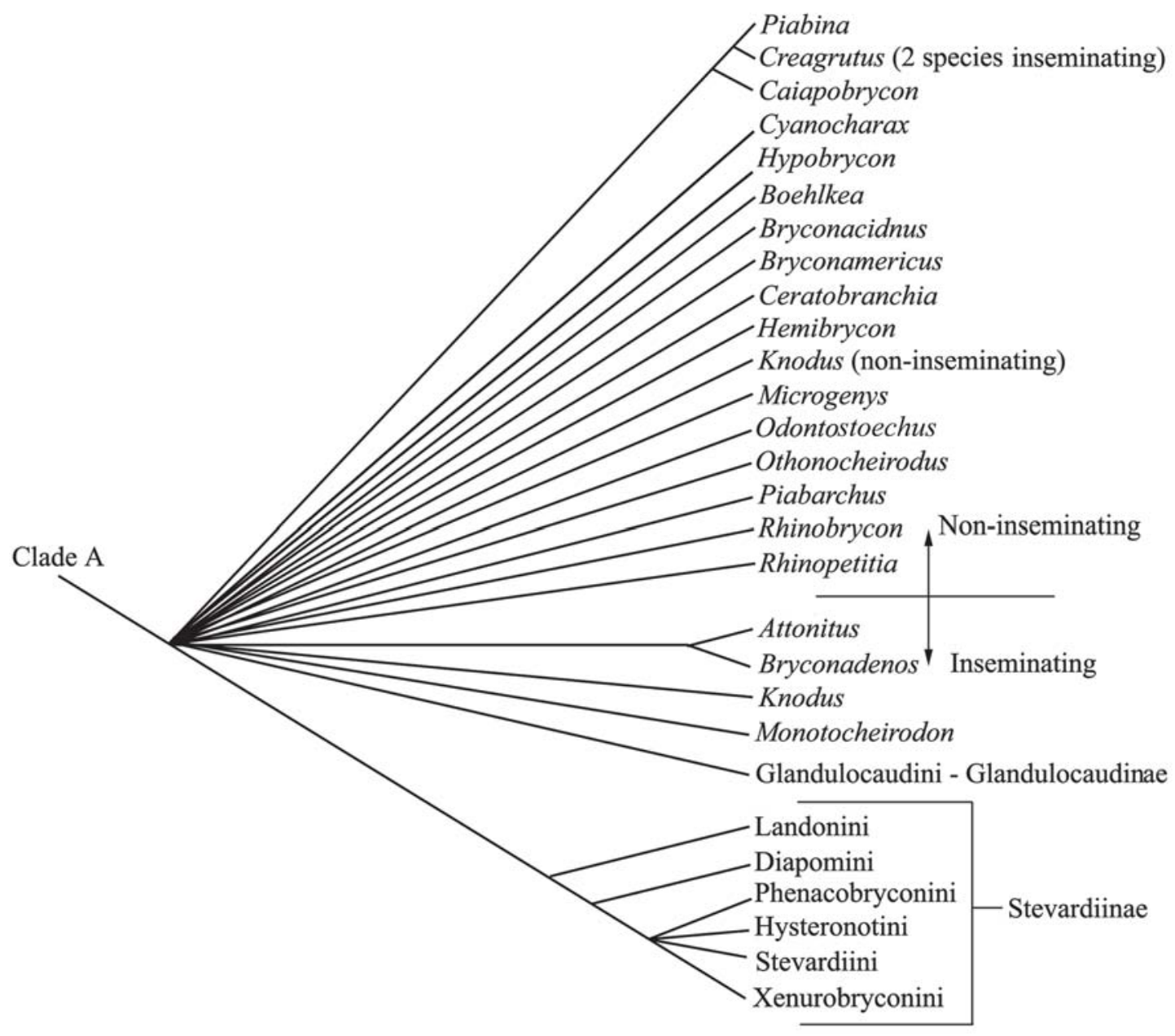

Fig. 1. Cladogram depicting hypothesized relationships among Clade A characids as modified here from Malabarba \& Weitzman (2003) with indication of non-inseminating and inseminating groups. 


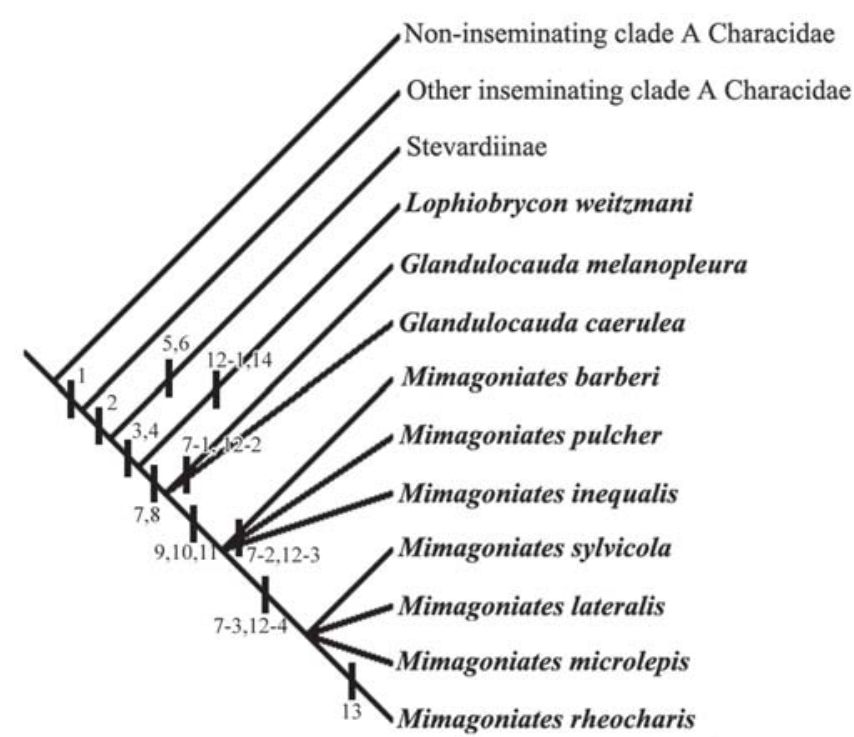

Fig. 2. Cladogram of the most parsimonious hypothesis showing the relationships of the genera and species of the Glandulocaudinae.

Table 1. Character state matrix for the glandulocaudine species and outgroups and characters described in "Glandulocaudine Phylogeny".

\begin{tabular}{|c|c|c|c|c|c|c|c|c|c|c|c|c|c|c|}
\hline Taxa/characters & 01 & & & & 05 & 06 & 07 & 08 & 09 & 10 & 11 & 12 & 13 & 14 \\
\hline $\begin{array}{l}\text { Non inseminating } \\
\text { Clade A characids }\end{array}$ & 0 & 0 & 0 & 0 & 0 & 0 & 0 & 0 & 0 & 0 & 0 & 0 & 0 & 0 \\
\hline $\begin{array}{l}\text { Other inseminating } \\
\text { Clade A characids }\end{array}$ & 1 & 0 & 0 & 0 & 0 & 0 & 0 & 0 & 0 & 0 & 0 & 0 & 0 & 0 \\
\hline Stevardiinae & 1 & 1 & 0 & 0 & 1 & 1 & 0 & 0 & 0 & 0 & 0 & 0 & 0 & 0 \\
\hline Lophiobrycon weitzmani & 1 & 1 & 1 & 1 & 0 & 0 & 0 & 0 & 0 & 0 & 0 & 1 & 0 & 1 \\
\hline Glandulocauda melanopleura & 1 & 1 & 1 & 1 & 0 & 0 & 1 & 1 & 0 & 0 & 0 & 2 & 0 & 0 \\
\hline Glandulocauda caerulea & 1 & 1 & 1 & 1 & 0 & 0 & 1 & 1 & 0 & 0 & 0 & 2 & 0 & 0 \\
\hline Mimagoniates inequalis & 1 & 1 & 1 & 1 & 0 & 0 & 2 & 1 & 1 & 1 & 1 & 3 & 0 & 0 \\
\hline Mimagoniates barberi & 1 & 1 & 1 & 1 & 0 & 0 & 2 & 1 & 1 & 1 & 1 & 3 & 0 & 0 \\
\hline Mimagoniates pulcher & 1 & 1 & 1 & 1 & 0 & 0 & 2 & 1 & 1 & 1 & 1 & 3 & 0 & 0 \\
\hline Mimagoniates sylvicola & 1 & 1 & 1 & 1 & 0 & 0 & 3 & 1 & 1 & 1 & 1 & 4 & 0 & 0 \\
\hline Mimagoniates lateralis & 1 & 1 & 1 & 1 & 0 & 0 & 3 & 1 & 1 & 1 & 1 & 4 & 0 & 0 \\
\hline Mimagoniates rheocharis & 1 & 1 & 1 & 1 & 0 & 0 & 3 & 1 & 1 & 1 & 1 & 4 & 1 & 0 \\
\hline Mimagonaites microlepis & 1 & & 1 & 1 & 0 & 0 & 3 & 1 & 1 & 1 & 1 & 4 & 0 & 0 \\
\hline
\end{tabular}

diagnosing the Glandulocaudinae which are considered unique for characiform fishes. The relationships within the Stevardiinae were not further analyzed since they are not pertinent to this study.

\section{Character descriptions and analysis}

Although it appears in the Glandulocaudinae that peramorphosis played an important role in the evolution of the caudal pheromone organ, paedomorphosis has also occurred in the evolution of some characters found in this subfamily. At least one other secondary sexual apomorphy, number of anal-fin hooks per fin ray, is quantitatively reduced, but those hooks that remain are terminally augmented in size in transition from the most basal species to the most distally located species in the cladogram. The distributional extent of the glandular tissue on the tail fin appears somewhat reduced in the number of fin rays bearing glandular cells in the more distal members of Mimagoniates. However, it is not at all clear that this is associated with a reduction in the total amount of glandular tissue which, although it becomes more narrowly distributed around the orifice of the glandular pump organ, may not be reduced in amount. In both cases these changes correlate with and are part of the overall increasing complexity of the other secondary sexual characters of the males of the distal species of Mimagoniates. Polarities for these and other characters are based on out group comparisons accomplished in the analysis, but in some particular instances developmental terminal additions recorded from maturing males have been used to further understand polarities of characters. The polarities of reductive characters were hypothesized using the same kind of criteria, mostly from outgroup information, as for all non-reductive characters. For the most part the reductive features correlate with other non-reductive transformation in hypothesizing phylogeny. In our studies parsimony ordered the result and the total number of transformation series showing innovative states in sexual maturation always outnumbered the number of transformation series hypothesized to be reductive. As in the Stevardiinae, in the Glandulocaudinae rarely are peramorphic and paedomorphic transformations among taxa clearly divorced from each other. They usually represent a complex interrelated series of character transformations from relatively plesiomorphic states to more derived states. Such mixtures can easily be seen in the Xenurobryconini studied by Weitzman \& Fink (1985) and Weitzman et al. (1994). Other studies of fish phylogeny have shown the number of reductive (paedomorphic) versus innovative (peramorphic) character changes to be roughly equal (Mabee, 1987), and sometimes paedomorphic are apparently more numerous (Schaefer et al., 1989). We follow the reasoning of Weitzman \& Fink (1985: 8-9) and Stiassny (1992) in the subjective process of recognition and use of synapomorphies that are parts of complex structures.

In character descriptions below Clade A outgroups refer to the taxa included in characid Clade A of Malabarba \& Weitzman (2003). Character descriptions refer comparatively to figures of each species presented along the text in this sequence: Lophiobrycon weitzmani, Figs. 3-10; Glandulocauda melanopleura, Figs. 11-19; Glandulocauda caerulea, Figs. 20-28; Mimagoniates inequalis, Figs. 29-35; Mimagoniates barberi, Figs. 36-44; Mimagoniates pulcher, Figs. 45-51; Mimagoniates lateralis, Figs. 52-62; Mimagoniates sylvicola, Figs. 63-69; Mimagoniates rheocharis, Figs. 70-76; Mimagoniates microlepis, Figs.77-95.

\section{Insemination: (0) absent; (1) present.}

Malabarba, Weitzman \& Burns in Malabarba (1998) established the Compsurini for an inseminating subgroup of the Cheirodontinae. Evidence presented in Malabarba (1998) indicated that this is embedded within the Cheirodontinae 
and that insemination in the Compsurini arose independently from this phenomenon in both inseminating Clade A and nonClade A characids. Weitzman et al. (2005) noted that the nonClade A characid genera Brittanichthys Géry and Hollandichthys Eigenmann are inseminating. Rachoviscus Myers with two species from black acid waters was discovered to be inseminating by Rodrigo Quevedo and by Robert Javonillo (pers. comm.), (males of R. graciliceps, USNM 28814 and USNM 355625, elongate sperm and a female of $R$. crassiceps, USNM 220756, elongate sperm cells within its ovary). Zarske \& Géry (2006) maintained the traditional hypothesis that Hollandichthys is related to Pseudochalceus Kner, but Pseudochalceus is not inseminating according to John Burns and Robert Javonillo (pers. comm.).

2. Glandular tissue of granular appearance in caudal organ of mature males (Figs. 5, 14, 23, 31, 37): (0) absent; (1) present.

Presence of glandular tissue in the caudal organ is an unique feature of the Glandulocaudinae and the Stevardiinae.

3. Modified, hypertrophied terminal caudal peduncle squamation extending onto caudal fin from ventral region of dorsal caudal-fin lobe (Figs. 15, 24, 32, 38, 58, 67, 75 and 85): (0) absent; (1) present.

In Lophiobrycon a slight enlargement of some of the terminal scales of the dorsal caudal lobe probably represents a plesiomorphic state of the modified scales of the upper caudal lobe observed in other glandulocaudins. In the Glandulocaudinae and Stevardiinae these hypertrophied scales may be circular or elongated and include the posterior scales of the midlateral row of body scales that would cover the lateral line if complete. These scales are mostly free from the fin rays, with their dorsal, posterior and ventral borders free, except in Lophiobrycon. Species in the Glandulocaudinae hypothesized to have the most derived condition have hypertrophied scales that form a tabular flat structure anteriorly imbricated with the scales of the upper half of the caudal peduncle. Anteriorly on their internal surfaces the scales that form this flat cluster are attached to the fin-ray membrane between principal caudal-fin rays 9-10. This flap of skin extends posteriorly along about one -quarter to one-half of the length of the flat medial surface of the tabular squamation.

Clade A outgroups lack modified, hypertrophied terminal caudal peduncle squamation and in the stevardiines the modified, hypertrophied terminal caudal peduncle squamation are derived from the ventral rather than the dorsal caudal-fin lobe (see character 6). Several other characid genera have caudal peduncle squamation extending onto the dorsal and/ or the ventral caudal-fin lobes; however, in these taxa the scales are not hypertrophied and diminish in size posteriorly on the fin. More significantly, they are not associated with derived glandular tissue. Other characids lack a free posterior or posteroventral border of caudal scales and the scales do enclose a dermal pouch.

4. Caudal gland cells consisting of modified club cells: (0) absent; (1) present.

Many and perhaps all stevardiines have secretory cells derived from mucous cells. Clade A outgroups have no caudal gland cells.

5. Caudal gland cells consisting of modified mucous cells: (0) absent; (1) present.

All Glandulocaudinae have secretory cells derived from club cells (see character 4). Clade A outgroups lack caudal gland cells.

6. Modified, hypertrophied terminal caudal peduncle squamation derived from ventral caudal-fin lobe (see illustrations in Weitzman \& Menezes, 1998).

The males of most stevardiine tribes have hypertrophied caudal-fin squamation that appears modified from the scales of the ventral caudal-fin lobe and excludes the lateral-line series of scales. In the Xenurobryconini the caudal pump squamation was hypothesized to be derived primarily from the posterior most lateral-line scale (Weitzman \& Fink, 1985: 21-26). Weitzman et al. (1994) and Weitzman \& Menezes (1998), however, demonstrated that the species of this tribe have their pouch scales derived from the posterior scale of the row of scales immediately ventral to the lateral line. Thus their derived scales differ from those occurring in the Glandulocaudinae.

7. Principal caudal-fin rays 11 and 12: (0) not decurved; (1) slightly decurved ventrally but not involved in the formation of a pump; (2) decurved and enlarged with a groove (rudimentary pump) between them; (3) decurved and modified to support a complex pump chamber in association with modified principal caudal-fin rays 9, 10, and 13 .

The ventral bowing of principal caudal-fin rays 11 and 12 are associated with the evolution of a complex fin-ray pump organ and form a transformation series. The character was treated as multistate and ordered. In Clade A outgroups, stevardiines and Lophiobrycon the principal caudal-fin rays 11 and 12 are straight. In a cleared and stained fully mature specimen of Lophiobrycon we were unable to see the condition of caudal-fin 11 and 12 described by Castro et al. (2003) as "very slightly decurved in their distal halfs". In Brittanichthys the caudal-fin rays arch ventrally, but only at their distal to middle regions, not proximally as in the Glandulocaudinae (Weitzman \& Fink, 1985: 46; Weitzman et al., 1994; Weitzman \& Malabarba, 1999: 425-427; Weitzman \& Menezes, 1998: 178, 180 and especially Weitzman et al., 2005). No other characids, except some undescribed apparent cheirodontines have caudal-fin rays that arch ventrally, but a complex or even simple fin-ray pump mechanisms centered in caudal-fin rays 11-12 is never involved.

The least complex condition is found in the species of Glandulocauda (Figs. 15 and 25) where principal rays 11 and 12 are simply bowed ventrally and no apparent pump is present although in bending the caudal fin during courtship the bowed rays of the male may cause water currents to pass over the organized glandular tissue of males. In the most intermediate 
species of Mimagoniates (M. barberi, M. inequalis and M. pulcher) these two fin rays are strongly decurved and enlarged with a groove between them. In the more derived species of the genus, M. microlepis, a complex pump chamber is present and supported by modified principal caudal rays 9-13 and especially 11 and 12, which are also strongly decurved (compare Figs. 32, 38 and 47 with Figs. 58, 67, 77 and 85).

\section{Anterior pelvic-fin ray: (0) unbranched; (1) branched.}

In Lophiobrycon, outgroup Clade A and stevardiines the anterior ray of the pelvic fin is unbranched. It is distally branched in species of Glandulocauda and Mimagoniates (Figs. 27, 34, 40, 49, 57, 66, 74 and 83). This ray must not be confused with the pelvic splint attached to anterior ray. The extent of the branching of anterior ray varies according to the species, the size of the specimens and/or perhaps sometimes the sex of specimens for at least one species.

In Glandulocauda melanopleura the presence or absence of branching of the anterior pelvic-fin ray appears about equal in both sexes, and at all examined body lengths. In G. caerulea, the feature is sexually dimorphic in the limited sample with the branched anterior pelvic-fin rays only in adult males. In $M$. inequalis we were able to capture only a few available fully mature specimens and about $90 \%$ adults of both sexes had branched elongate anterior pelvic-fin rays, while more of the immature specimens had unbranched rather than branched first pelvic-fin rays. For $M$. barberi the distribution of branched versus unbranched first pelvic-fin rays in the few specimens in the adult size range of both sexes appeared relatively equal. In M. pulcher all immature and the $10 \%$ available maturing specimens of both sexes, had branched rays. In M. lateralis about three-fourths of both males and females specimens had branched anterior pelvic-fin rays. Mimagoniates sylvicola had branched anterior pelvic-fin rays at all body lengths in both sexes. We had relatively few specimens of $M$. rheocharis and, except for a few small immatures, $90 \%$ of them had branched anterior first pelvic rays. Finally, we had numerous specimens of $M$. microlepis, although few very large adults. Most immatures had either branched or unbranched first pelvic rays, but all available specimens nearing the size of full maturity, past $40 \mathrm{~mm} \mathrm{SL}$, had branched anterior pelvic-fin rays.

9. Scales at base of dorsal caudal-fin lobe: (0) not elongate; (1) most elongate, at least more than twice as long as wide.

Presence of elongate scales at base of dorsal caudal-fin lobe extending posteriorly as a flap to loosely cover area of glandular tissue is an exclusive feature of Mimagoniates. In species of this genus with more elongate caudal organ, scales are proportionally longer (Figs. 32, 38, 67, 75 and 85).

No member of clade A outgroups or any other putatively outgroup to the Glandulocaudinae or members of Lophiobrycon, Glandulocauda and the stevardiines have elongate scales at base of dorsal caudal-fin lobe.

10. Hooks on anal-fin rays of males: (0) 2 or more on any analfin fin ray that bears hooks; (1) 0 to 1 on any anal-fin ray that bears hooks.

Adult males of the species of Mimagoniates have 0 to 1 hooks on those anal-fin rays that bear hooks (Figs. 33, 39, 50, 56, 65, 73 and 81), except that some might have an additional very small hook on anterior most branched anal-fin ray (see Fig. 33 of Mimagoniates inequalis).

Species of Lophiobrycon (Fig. 6), Glandulocauda (Figs. 16 and 26) and members of clade A characids with anal-fin ray hooks have two or more hooks on each ray.

11. Premaxillary teeth: (0) in two rows; (1) in one irregular row. The premaxillary teeth of Mimagoniates are relatively compressed, suggesting a multicuspid incisor rather than the often thick, rounded basal portion multicuspid tooth typical of many "tetragonopterines". In some of the smaller species of Mimagoniates (e.g. M. inequalis, approximately $30.0-35.0 \mathrm{~mm}$ $\mathrm{SL}$ ) the teeth on the premaxilla, are in a row. The two posterior most teeth are clearly in a single row, the next tooth inclines medially somewhat, but it is in line with the two posterior teeth. The next anterior tooth lies in the same somewhat curved plane as the two posterior most teeth. The next three teeth have their basal attachments not exactly aligned with the others, but it is difficult to characterize two rows. Much larger (60.0 mm SL) specimens of $M$. microlepis, for example, may have as many as 12 teeth on a premaxilla. Gradations of the two arrangements just described occur in young to adult $M$. microlepis and many of the other species in the genus show intermediate conditions. Under these circumstances we do not describe the premaxillary teeth of Mimagoniates as being in two rows. We therefore consider the premaxillary teeth as forming a single unit rather than artificially divide the teeth into two rows.

In Lophiobrycon (see fig. 6 in Castro et al., 2003), Glandulocauda (Figs. 18 and 28), most outgroup clade A, and stevardiines the premaxillary teeth clearly form two rows close to each other, but the attachments of the teeth to the jaws are clearly separated.

12. Caudal-fin ray pump: (0) principal caudal-fin rays 11 and 12 not modified; glandular tissue not distributed along caudalfin rays; (1) principal caudal-fin rays 11 and 12 not modified; glandular tissue widespread along principal caudal-fin rays 11-15; (2) principal caudal-fin rays 11 and 12 slightly decurved; glandular tissue widespread along principal caudal-fin rays 10-15; (3) principal caudal-fin rays 11 and 12 decurved and enlarged, forming a rudimentary ray-pump organ; glandular tissue mostly concentrated to area immediately around and on pump organ; (4) principal caudal-fin rays 11 and 12 strongly curved and modified to form a complex ray-pump organ; glandular tissue confined to area immediately around and on caudal pump region of gland.

There seems to be a correlation between ventral bowing of principal caudal-fin rays 11 and 12 and the distribution of glandular tissue on caudal-fin forming a transformation series within the Glandulocaudinae. The character was also treated as multistate and ordered.

In stevardiines and outgroup Clade A principal caudal- 
fin rays 11 and 12 are not bowed and the glandular tissue is not distributed along some of the principal caudal-fin rays. In Lophiobrycon (Fig. 5) the hypertrophied, active caudal glandular tissue is widely distributed in beaded rows from the eleventh through the fifteenth principal caudal rays of the ventral caudal-fin lobe, but principal caudal-fin rays are not ventrally decurved. In Glandulocauda principal caudal-fin rays 11 and 12 are slightly decurved (Figs. 15 and 25) and the glandular tissue is distributed along the ninth or tenth principal fin rays of the dorsal caudal-fin lobe through the fourteenth or the fifteenth principal rays of the ventral caudal-fin lobe (Figs. 14 and 23). Mimagoniates barberi (Fig. 37), a relatively basal species of that genus has the hypertrophied beaded glandular tissue mostly confined to the area of the groove between finrays 11 and 12 (Fig. 38) and is not spread widely along the fin rays. This suggests that this groove may be involved with the dissemination of a pheromone or pheromones when the caudal fin is in motion. In M. inequalis (Fig. 32), M. barberi (Fig. 38) and M. pulcher (Fig. 47) relatively basal species of Mimagoniates, principal caudal-fin rays 11 and 12 are curved and enlarged and involved in the formation of a rudimentary fin-ray pump. The hypertrophied and beaded glandular tissue is most concentrated in the area of the groove between rays 11 and 12 (Figs. 32 and 38). In the species of Mimagoniates more distally located on the cladogram, principal caudal-fin rays 11 and 12 are curved and involved in the formation of a welldeveloped pump organ and the hypertrophied glandular tissue is most concentrated to an area immediately around and on caudal pump region (Figs. 54 and 80). In males of those species with a well-developed pump organ the concentrated glandular tissue is rarely beaded in appearance. However, in the case of M. rheocharis (Fig. 72) there is indication of beading.

13. Sturdy hooks on principal caudal-fin ray 11: (0) absent; (1) present.

Presence of sturdy hooks on $11^{\text {th }}$ principal caudal-fin ray (Fig. 75) is an autapomorphy of Mimagoniates rheocharis. The caudal-fin hooks in other species of Mimagoniates are spine-like.

14. Urogenital papilla: (0) absent in females; (1) present in females.

A well-developed urogenital papilla (Fig. 8) is exclusively present in females of Lophiobrycon weitzmani.

\section{Glandulocaudinae Eigenmann, 1914}

Diagnosis. Synapomorphies 3 (modified, hypertrophied terminal caudal peduncle squamation extending onto caudal fin from ventral region of dorsal caudal-fin lobe) and 4 (caudal gland cells consisting of modified club cells) discussed above are unequivocal conditions that corroborate the hypothesis that Lophiobrycon, Glandulocauda, and Mimagoniates form a monophyletic group.

Synonymy. The following limited synonymy includes family group names proposed for what is here considered the Glandulocaudinae and is equivalent to the former tribe Glandulocaudini and its genera, Lophiobrycon, Glandulocauda and Mimagoniates. Some of these family group names included more inseminating genera than are here considered glandulocaudines in our restricted sense, but at least they included one or more of the three genera included here in the Glandulocaudinae. The removal of the Glandulocaudini from the "traditional” Glandulocaudinae left the remaining tribes and genera of that traditional subfamily without a family group name. We use the earliest family group name available, Stevardiinae Gill (1858: 422), for genera Acrobrycon, Argopleura, Chrysobrycon, Corynopoma, Diapoma, Gephyrocharax, Hysteronotus, Iotabrycon, Landonia, Phenacobrycon, Planaltina, Pseudocorynopoma, Pterobrycon, Ptychocharax, Scopaeocharax, Tyttocharax, and Xenurobrycon. The use of a Stevardiinae as a more inclusive subfamily as proposed by Mirande (2009) is not accepted here for the reasons explained in the introduction. The history of the investigation of the Glandulocaudinae as here recognized is treated in some detail below.

Glandulocaudinae Eigenmann (1914: 34). Eigenmann proposed this name for Coelurichthys (currently = Mimagoniates), Diapoma, Gephyrocharax, Glandulocauda, Hysteronotus, Microbrycon (= Pterobrycon), Pseudocorynopoma, and Stevardia (= Corynopoma), all of which ultimately proved to be inseminating.

In addition to the genera listed above under Stevardiinae, Weitzman (2003) listed Glandulocauda and Mimagoniates in his Glandulocaudinae, but as discussed here, Weitzman et al. (2005) restricted the use of this name to three genera, Lophiobrycon, Glandulocauda and Mimagoniates.

Glandulocaudini sensu Myers \& Böhlke (1956: 6). These authors included all of the then known glandulocaudines except the xenurobryconins. They provided no definition or diagnosis of their Glandulocaudini. Géry (1977: 355), followed (Myers \& Böhlke, 1956). Weitzman et al. (1988: 384), restricted use of Glandulocaudini to species of Glandulocauda and Mimagoniates and provided a diagnosis of the tribe. Menezes \& Weitzman (1990: 383), followed the same usage as Weitzman et al. (1988), but provided a key to genera and species of the tribe. Weitzman \& Menezes (1998: 183) provided a diagnosis of the tribe.

Stevardiidi sensu Géry (1966: 227). This was an alternative tribal name used to designate the equivalent of entire traditional Glandulocaudinae exclusive of Xenurobryconini. No definition or diagnosis was provided by Géry. Stevardiidi was a substitute name for the tribe Glandulocaudini of Myers \& Böhlke (1956).

\section{Discussion and history of the Glandulocaudinae systematics}

The first use of the family group name Glandulocaudinae was by Eigenmann (1914: 34). Eigenmann (1914: 34-35) included eleven characid genera in his Glandulocaudinae. These genera included those American characid species that Eigenmann 
perceived as bearing modified scales and an apparent glandular structure in the basal caudal-fin region. At present we recognize ten of Eigenmann's original generic taxa, although, due to priority of earlier names, some of them now have different names (see Weitzman \& Fink, 1985; Weitzman \& Menezes, 1998 and Weitzman, 2003). Over the years various new genera were added to the subfamily until Weitzman \& Fink (1985: 1-3) recognized 17 genera and over 40 species in the subfamily. Weitzman et al. (1994) described a new genus, Ptychocharax, Weitzman \& Menezes (1998: 187) described another, Chrysobrycon, and Castro et al. (2003) described a third new genus, Lophiobrycon. The first two were placed in the Xenurobryconini, herein included in the subfamily Stevardiinae and the third in the Glandulocaudini of Weitzman \& Menezes (1998) and Weitzman (2003) bringing the total number of genera to 20.

The history of the use of generic names and the relationships of taxa within the Glandulocaudini (our Glandulocaudinae) are complex and confused. This is partly based on misidentification of species as well as misinterpretations of generic limits based on unresolved nomenclatural problems and obfuscated by non-use of pertinent anatomical data.

Menezes \& Weitzman (1990: 383-384), Weitzman et al. (1988: 384-413), Weitzman \& Fink (1985: 109) provided evidence that the species they placed in Glandulocauda and Mimagoniates form a monophyletic group based on male secondary sexual synapomorphies. Castro et al. (2003) included their new genus Lophiobrycon in the Glandulocaudini (our Glandulocaudinae) and, based on the absence of certain secondary sexual characters in the genus, suggested that the tribal diagnosis should be reformulated. Géry (1977: 362) briefly discussed Mimagoniates and his concept of Glandulocauda but made no comments on their possible monophyly.

Menezes \& Weitzman (1990: 384-385) and Weitzman \& Fink (1985: 22) demonstrated that not only are the two species G. melanopleura and G. caerulea (their G. melanogenys and G. melanopleura respectively) distinct from the species of Mimagoniates, including $M$. inequalis, but that the species of Mimagoniates accepted by them form a monophyletic group with the two species of Glandulocauda belonging to an outgroup of uncertain monophyly other than they are members of what we formerly considered to be the tribe Glandulocaudini. They noted that they had no synapomorphies with testable polarity hypotheses to unite these two species in the monophyletic genus Glandulocauda and left these terminal taxa in an unresolved trichotomy with a third line leading to the species of Mimagoniates. Weitzman \& Menezes (1998) considered Glandulocauda as sister group of Mimagoniates both genera forming Clade 2 of their Glandulocaudinae. More recently Castro et al. (2003) included their new genus Lophiobrycon in the Glandulocaudini (our Glandulocaudinae) as a sister group for the clade including Glandulocauda and Mimagoniates.

Nelson (1964a: 63-65) in part reviewed the nomenclatural history of the nominal species of Mimagoniates, Glandulocauda, and Coelurichthys. He also examined the types of $M$. barberi, specimens of $M$. inequalis, types of $M$. lateralis [which both he and Géry referred to as M. tenuis (Nichols)] and specimens of M. microlepis. Note that Weitzman \& Fink (1985: 106, 109), just as Nelson (1964a: 64), after his study was in press, concluded that $M$. lateralis is a senior synonym of $M$. tenuis because the holotypes of these nominal species are a male and a female of the same species. Mimagoniates lateralis has page precedence regarding $M$. tenuis. Nelson (1964a) further placed M. microlepis and $M$. lateralis in Coelurichthys and based his judgment on the correct observation that $M$. inequalis was closer anatomically to the type species of Mimagoniates, $M$. barberi. Because $M$. lateralis and $M$. microlepis are different in their caudal structures from $M$. barberi and $M$. inequalis, he considered himself justified in placing $M$. lateralis and M. microlepis in Coelurichthys. His observations of the differences in courtship behavior of $M$. inequalis, $M$. lateralis, and M. microlepis also influenced his decision. A decision to recognize Coelurichthys using Nelson's criteria remains subjective. Below we explain our reasons for rejecting Coelurichthys as a valid genus.

Menezes \& Weitzman (1990: 383-387) prepared a key to the species of Glandulocauda and Mimagoniates based on specimens from over 200 localities in Brazil and Paraguay. They recognized six species of Mimagoniates, $M$. inequalis, M. barberi, $M$. sylvicola, $M$. lateralis (with $M$. tenuis as a synonym), $M$. rheocharis, and $M$. microlepis (with $M$. iporangae as a synonym). They maintained all these species in Mimagoniates because, based on several secondary sexual characters of the males, they appear to form a monophyletic lineage. Menezes \& Weitzman (1990: 419-421) discussed at some length the possibility that one of their new species, $M$. rheocharis, may have originated by introgression between $M$. inequalis, one of the basal members of the genus, and $M$. microlepis, the most distal species of the genus according to specializations of the male secondary sexual characters. Menezes \& Weitzman (1990: 416-421) presented some anatomical evidence for this hypothesis, but did not commit themselves to it. They also presented evidence for an alternate hypothesis, that $M$. rheocharis is a less distal sister species to M. microlepis. Although they favored the later hypothesis, they concluded that more information from population samples from appropriate geographical localities, genetic information and hybridization experiments were needed before the possible hybrid nature of the origin of this species could be accepted. Regarding this possible introgression between $M$. inequalis and M. microlepis, Nelson (1964b: 127) found the behavior of these two species quite different and was unable to get interspecific courtship between them. Considering the large differences in the secondary sexual morphology of these two species we are not surprised about Nelson (1964a, 1964b) findings. This would suggest that if hybridization occurs at all between these two species, it must be rare. Additional breeding experiments should be undertaken to confirm or reject Nelson (1964a, 1964b) results. The phylogenetic relationships among the seven species we place in Mimagoniates are complex and not fully resolved. Although the name $M$. 
microlepis (Steindachner, 1876), is a senior synonym of Coelurichthys iporangae. Miranda-Ribeiro (1908), the recognition of Coelurichthys as a valid genus would, according to our cladogram (Fig. 2), make Mimagoniates paraphyletic. Thus we recognize only Mimagoniates.

The use of generic names in the Glandulocaudini (= Glandulocaudinae of this study) needs some further explanation. Several choices were available. We were guided in our usage of generic names by our phylogeny so far hypothesized for the taxa of the subfamily and by an attempt to be as conservative as possible in the use of names. As discussed below in some detail, various authors have used generic names in the group in a variety of ways and we here explain why we have rejected some of those usages.

For example, Schultz (1959) used the oldest available generic name, Mimagoniates, for all the species of Glandulocauda and Mimagoniates. In this case the generic name would be equivalent in taxonomic level to the clade including the species of these two genera (Fig. 2) accepted here.

There are other possible choices for generic name usage in the Glandulocaudinae. A different generic name could be used for each species and the result would be similar to the uninomial nomenclature or recognition of only monotypic genera as discussed but not recommended by Hubbs (1943: 112-113) for eliminating subjectivity in the use of scientific names. In spite of Hubbs' suggestion that this is a way to eliminate subjectivity in use of scientific names, we submit that this is only one of the many subjective schemes that could be suggested for naming organisms. This one unfortunately would eliminate the convenient and meaningful use of generic names to designate monophyletic lineages.

\section{Key to the genera and species of the Glandulocaudinae}

1a. Females without an obvious derived urogenital papilla; dorsal-fin origin closer to caudal-fin base than to tip of snout (compare Figs. 11 and 20); 5 to 15 hooks on anterior three branched anal-fin rays of adult males (Figs. 16 and 26); adipose fin of both sexes short based ....

1b. Females with urogenital papilla with a posterior opening and anus located at its base (see Fig. 8); dorsal-fin origin closer to tip of snout than to caudal-fin base (Fig. 3); adipose fin long based in sexually mature males, extending from posterior termination of base of dorsal fin to base of dorsal lobe of caudal fin (Fig. 3); 1 to 3 hooks on anterior three branched anal-fin rays of adult males (Fig. 6) (Headwater tributary streams of rio Grande, upper Paraná system, Minas Gerais State, southeastern Brazil) . Lophiobrycon weitzmani

2a. Male derived caudal-fin pump absent at all ages; adult males with more than one hook on anal-fin rays that bear hooks (Figs. 16 and 26) (rio Ribeira de Iguape, rio Tietê, rio Grande basins, and rio Guaratuba, all in São Paulo and rio Iguaçu, in Paraná and Santa Catarina States, Brazil) Glandulocauda (3)

2b. Caudal fin-ray pump present in mature males, modified primarily from caudal-fin rays 10-13, sometimes relatively simple and represented by expanded, flattened anterior portions of ray halves; in some species an anterior fin-ray pump chamber is present (Figs. 32, 38, 47, 58, 67, 75 and 85); adult males usually with no more than 1 hook on analfin rays that bear hooks, sometimes 2 hooks on anterior divided ray and 3 on longest unbranched anterior ray (Figs. 33, 39, 50, 56, 65, 73 and 81) (Coastal streams from southern Bahia in eastern Brazil to northeastern Uruguay and in parts of the rio Paraná drainage in west central Brazil and in Paraguay). Mimagoniates (4)

3a. Number of branched anal-fin rays 20-24; number of lateral series scales 37-42; number of horizontal scale rows between dorsal-fin origin and anal-fin origin 13-16; number of vertebrae 36-38; in life, body color of breeding males predominantly pale yellow greenish brown (upper rio Tietê, rio Juquiá, upper rio Ribeira drainage, rio Itatinga and upper rio Guaratuba, São Paulo State, Brazil ......... Glandulocauda melanopleura

3b. Number of branched anal-fin rays 15-18; number of lateral series scales 31-35; number of horizontal scale rows between dorsal- and anal-fin origins 11-13; total number of vertebrae 34-36; in life, body color of breeding males predominantly pale blue (Upper rio Iguaçu in Paraná and Santa Catarina States, Brazil) . Glandulocauda caerulea, new substitute name

4a. Caudal fin-ray pump little developed in males of completed sexual maturity and without obvious pump chamber enclosed by modified proximal portions of caudal-fin ray halves 11 and 12; ray halves of this region of these rays modified into expanded, flattened structures parallel to one another; these modified ray halves of each side of caudal fin developed so that a groove exists between them; groove and accompanying hypertrophied glandular tissue constitute a plesiomorphic pump organ (Figs. 32, 38 and 47) .

4b. Caudal fin-ray pump well-developed in males of completed sexual maturity, consisting of bilateral chambers, one on each side of fin and each chamber enclosed by flattened expanded portions of ray halves of rays 11 and 12; pump chamber with an obvious posterior opening, and a lateral slit-like opening (Figs. 58, 67, 75 and 85) ..

5 a. Branched anal-fin rays 23-30, usually 25-27, rarely 28 to 30 ; scales in lateral series (including lateral-line scales) 3441, usually 37-40; scale rows between dorsal- and anal-fin origins 15-18; dorsal-fin origin at vertical line drawn from base of second or third branched anal-fin ray; mid-lateral dark body stripe of adult males diffuse, poorly developed, often not apparent; body depth of adults at anal-fin origin approximately 2.8 to 3.0 in SL (Tributaries of lago Guaíba, laguna dos Patos and lagoa Mirim, in Rio Grande do Sul State, Brazil and in northeastern Uruguay) Mimagoniates inequalis

5b. Branched anal-fin rays 30-36, usually 31-34; scales in lateral series 41-48; scale rows between dorsal- and anal-fin origins 13-15; dorsal-fin origin at line drawn vertically from base of seventh to ninth branched anal-fin rays; lateral dark body stripe of adult males nearly black, clearly distinct; 
body depth of adults at anal-fin origin about 3.1 to 3.3 times in SL (Tributaries of rio Paraguay in parts of Brazil and Paraguay ) ................................ Mimagoniates barberi 5c. Branched anal-fin rays 26-30, usually 28-29; scales in a lateral series 43-49; scale rows between dorsal- and analfin origins 13-15; dorsal-fin origin at line drawn vertically from base of third to fifth branched anal-fin rays; mid lateral dark body stripe of adult males well- developed; body depth at dorsal-fin origin of adults 3.8-4.0 in SL (Locality not precisely determined in Mato Grosso. See notes on type locality) Mimagoniates pulcher new species

$6 a$. Hooks absent on all principal caudal-fin rays of adult males (Figs. 58 and 67) ...(7)

$6 \mathrm{~b}$. Hooks present on at least principal caudal-fin rays 10 and 11 of adult males, hooks also frequently present on ray 12 . (Figs. 75 and 85)

7a. Lateral series scales 49-56; scale rows between dorsal- and anal-fin origins 16-18; body depth of adult males $3.4-3.8 \%$ in SL; in wild caught specimens body silvery blue, when black horizontal stripe present, located at and partly dorsal to midlateral region of body from tip of snout to central caudal-fin rays, stripe diffuse and broad and often obscured by silvery blue coloration posteriorly and by silvery pigment anteriorly; stripe rarely clearly defined (Tributaries of Atlantic Ocean in southern Bahia State, Brazil) ..... M. sylvicola

7b. Lateral series scales 37-44; scale rows between dorsaland anal-fin origins 12-15; body depth of adult males 3.85.1 in SL; in wild caught specimens body mahogany brown, especially dorsally, with dark brown, nearly black, horizontal lateral body stripe below mid-region of body prominent and extending from tip of lower jaw, posteriorly ventral to eye, across opercle and body sides just ventral to mid body region onto caudal peduncle and across central portion of caudal fin (Tributaries of Atlantic Ocean from Santos, São Paulo south to Joinville, Santa Catarina State, Brazil) M. lateralis

8a. Branched anal-fin rays 23-29, usually 24-26; branched dorsal-fin rays 8-12, rarely 8; scale rows between dorsaland anal-fin origins $17-22$, usually 19-20; scale rows around caudal peduncle 19-23, usually 20-22 branched dorsal-fin rays $8-12$, rarely 8 ; very small hooks on caudal-fin rays 11 12 of fully adult males (Fig. 75); dorsal-fin origin at vertical drawn from anal-fin origin or from base of 2 to 4 rays posterior to anal-fin origin (Tributaries to Atlantic Ocean of southern Santa Catarina and northern Rio Grande do Sul States, Brazil) M. rheocharis

8b. Branched anal-fin rays 26-33, usually 28-31; branched dorsal-fin rays 7-9, rarely 9; scale rows between dorsaland anal-fin origins 14-17, usually 15-16; scale rows around caudal peduncle 15-18; numerous strong hooks on at least caudal-fin rays 11-12 (sometimes 7-12) of fully adult males (Fig. 85); dorsal-fin origin at a vertical draw from base of branched anal-fin rays 5 or 6 (Tributaries to Atlantic Ocean from southern Bahia south to Rio Grande do Sul States, rio Tibagi, upper rio Paraná basin and upper rio Iguaçu, Paraná State. M. microlepis

\section{Lophiobrycon Castro, Ribeiro, Benine \& Melo, 2003}

Lophiobrycon Castro, Ribeiro, Benine \& Melo, 2003: 11 (type species: Lophiobrycon weitzmani Castro, Ribeiro, Benine \& Melo, 2003: 11-19 by monotypy and original designation).

Diagnosis. Lophiobrycon can be distinguished from the other two genera of the subfamily by having the adipose fin long based in sexually mature males (Fig. 3) extending from posterior termination of base of dorsal fin to base of dorsal lobe of caudal fin, a urogenital papilla (Fig. 8) with a posterior opening and anus located at its base in the females, and the dorsal-fin origin closer to snout tip than to caudal-fin base. In Glandulocauda and Mimagoniates the males have a short based adipose fin (Figs.11 and 20), a urogenital papilla is lacking in females and the dorsal-fin origin is closer to caudalfin base than to snout tip. Also in Lophiobrycon only 1 to 3 hooks (Fig. 6) are present on the anterior three branched analfin rays of adult males, contrasting with the presence of 5 to 15 hooks on the anterior three branched anal-fin rays of adult males (Figs. 16 and 26) in Glandulocauda and Mimagoniates.

Remarks. Lophiobrycon shares with Glandulocauda plesiomorphic states of characters 9, 10 and 11 discussed in the phylogeny section with respect to the derived conditions of these characters in Mimagoniates. It was regarded by Castro et al. (2003: 14) as the sister group to the clade represented by Glandulocauda and Mimagoniates (see Castro et al., 2003, fig. 8). Their conclusion was based on the absence of modified scales on the upper caudal-fin lobe of Lophiobrycon (Castro et al., 2003, fig. 4). The state described as "an apparent concentration of bead-like hypertrophied glandular tissue along the borders of the proximal portions of caudal-fin rays 11 and 12, that are slightly decurved in their distal half" would represent the most plesiomorphic state of the caudal organ in any glandulocaudine. These characters are discussed in the phylogeny section above.

\section{Lophiobrycon weitzmani Castro, Ribeiro, Benine \& Melo, 2003 \\ Figs. 3-4}

Lophiobrycon weitzmani Castro, Ribeiro, Benine \& Melo 2003: 14, figs. 1-9 (type locality: as given below for holotype; phylogenetic considerations; biogeography). - Weitzman et al., 2005: 344, 345, 347 (presence of club cells; comments on insemination; phylogenetic relationships). - Langeani et al., 2007: 184 (size; origin and occurrence in the upper rio Paraná). - Menezes, in Buckup et al., 2007: 38 (listed in catalog; distribution; conservation status).

Diagnosis. Same as the distinguishing characters given in the diagnosis of Lophiobrycon above.

Description. Table 2 presents morphometrics of holotype and 


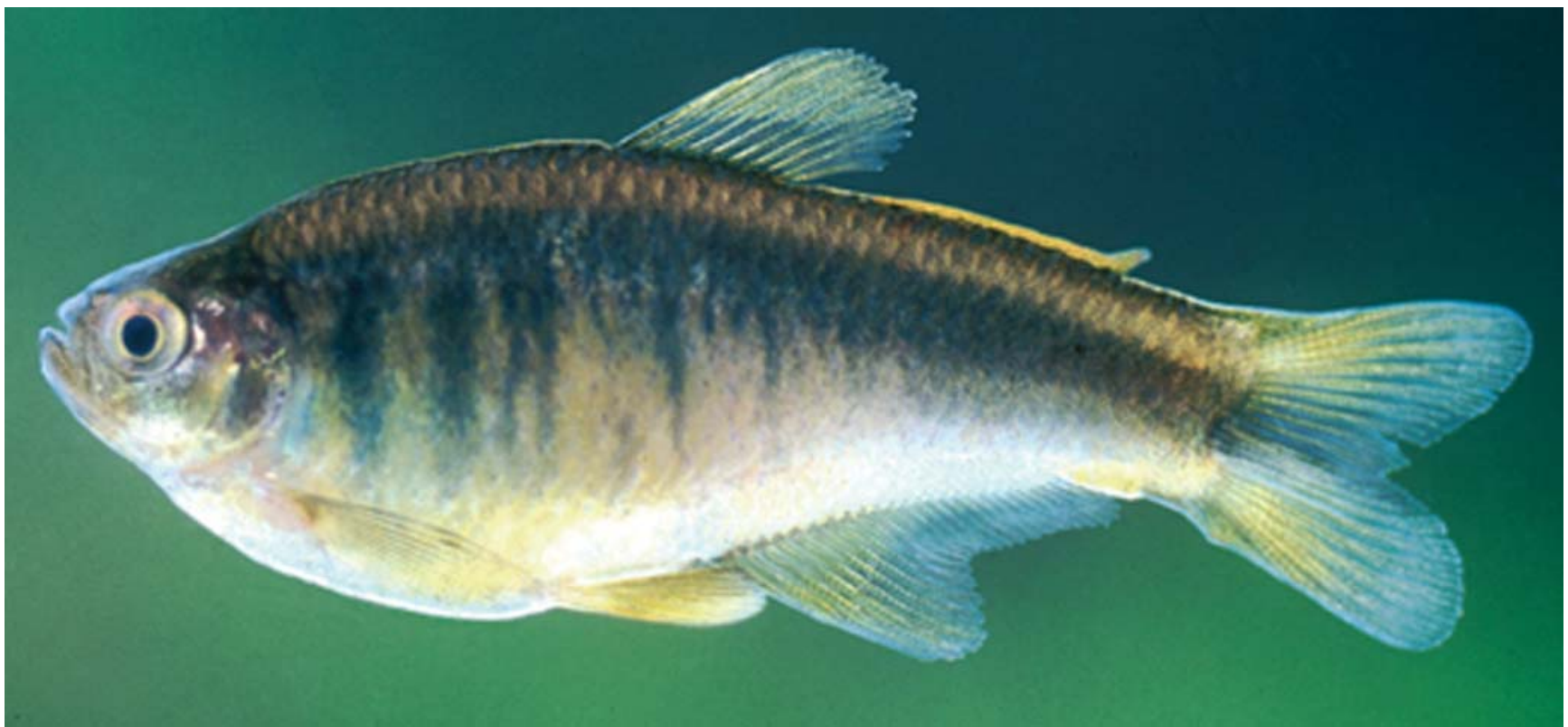

Fig. 3. Lophiobrycon weitzmani, paratype, adult male, LIRP 4338, $33.1 \mathrm{~mm}$ SL, Brazil, Minas Gerais, rio Grande basin, upper rio Paraná, município de Delfinópolis, Estância Carmen Sílvia, córrego Bom Jesus. Modified from Castro et al. (2003).

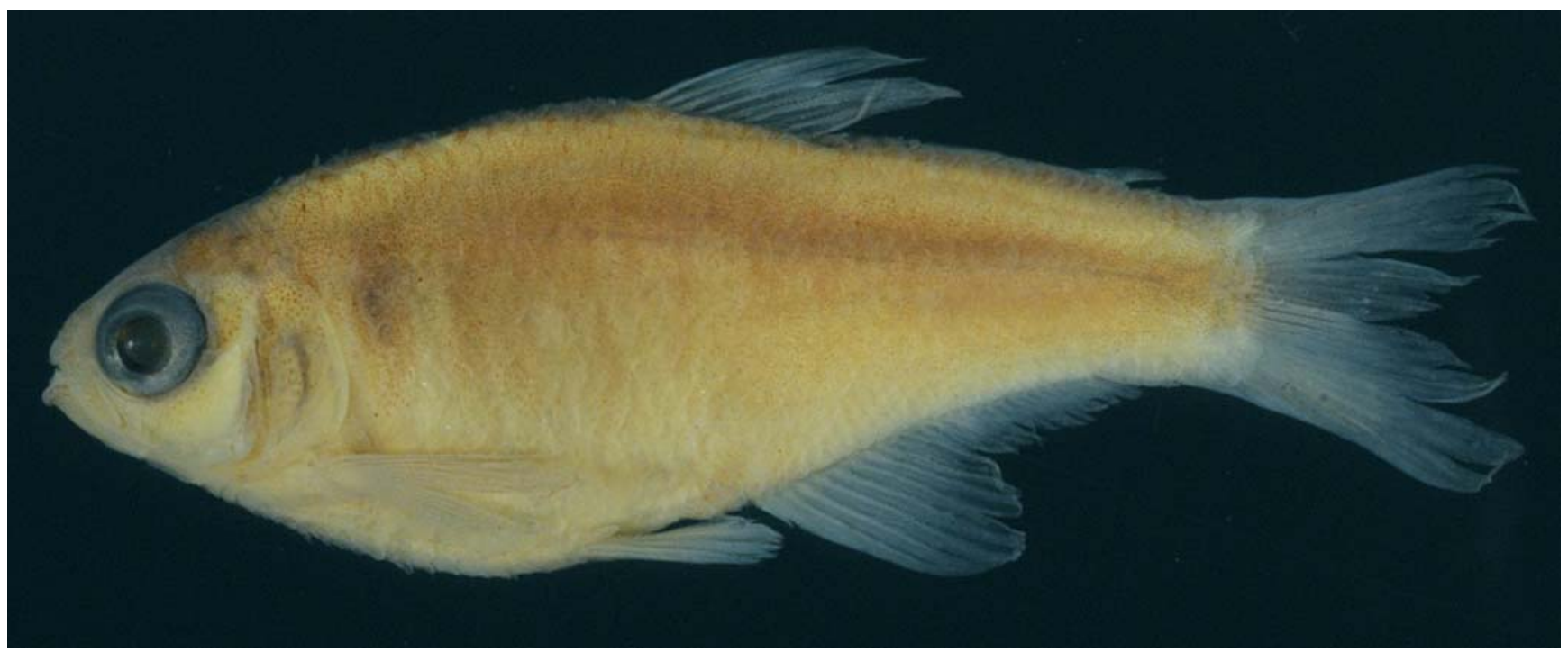

Fig. 4. Lophiobrycon weitzmani, paratype, adult female. MZUSP 83353, 21.8 mm SL; same locality data as in Fig. 3.

paratypes. Body compressed, relatively deep, especially near dorsal-fin origin; body deepest at vertical through pelvic-fin origin. Predorsal profile relatively arched in adult males, less so in females and immatures in which predorsal profile gently convex to tip of snout. Dorsal profile strongly arched in males, less so in females and juveniles, nearly straight along dorsalfin base and to origin of dorsal procurrent rays. Dorsal-fin origin nearer to snout tip than to caudal-fin base. Ventral profile of body strongly convex in adult males from anterior tip of lower jaw to origin of pelvic fins, less convex in females and juveniles. Abdominal profile in adult males slightly concave to anal-fin origin, straight or nearly so in females and juveniles. Body profile along anal-fin base in males slightly concave anteriorly in region of anterior lobe of anal fin, straight or nearly so along remainder of fin base in males. Profile straight along entire analfin base in females and juveniles.

Lower jaw protruding, extending slightly anterior to tip of upper jaw. Lower jaw of adult males thick and heavy compared to that of females and juveniles. Mouth angled posteroventrally. Maxilla extends posteriorly to point slightly anterior of vertical through anterior border of pupil.

Dorsal-fin rays ii, 8 (in all specimens, $n=54$ ); posterior ray split to its base and counted as one ray. Adipose fin unusually long in adult males (see Castro et al., 2003: 5, fig. 1a). Anal-fin unbranched rays iii-iv (iv), 20-23 (20), 21.8, $n=54$; posterior ray split to its base and counted as 1 ray. Anal fin with 
Table 2. Morphometrics of Lophiobrycon weitzmani. Standard length is expressed in mm; measurements through bony head length are percentages of standard length; the last four entries are percentages head length. A plus sign under the abbreviation dif. indicates there is a significant statistical difference between the males and females in the particular character indicated. All specimens are from the type locality, Brazil, Minas Gerais, rio Grande basin, LIRP 4366 (holotype), (remainder are paratypes) LIRP 4338, LIRP 4339, MZUSP 83353, MCP 34194. SD = Standard deviation.

\begin{tabular}{|c|c|c|c|c|c|c|c|c|c|c|}
\hline \multirow{2}{*}{ Characters } & \multicolumn{5}{|c|}{ Males } & \multicolumn{5}{|c|}{ Females } \\
\hline & Holotype & $\mathrm{N}$ & Range & Mean & SD & $\mathrm{N}$ & Range & Mean & SD & dif. \\
\hline Standard length & 26.0 & 22 & $14.8-30.0$ & 22.2 & & 32 & $13.5-25.0$ & 18.9 & & \\
\hline Depth at dorsal-fin origin & 37.7 & 22 & $30.4-55.7$ & 36.0 & 5.1 & 32 & $30.0-36.7$ & 33.6 & 2.1 & - \\
\hline Snout to dorsal-fin origin & 50.0 & 22 & $49.1-56.3$ & 52.5 & 2.1 & 32 & $53.2-56.6$ & 54.9 & 1.1 & + \\
\hline Snout to pectoral-fin origin & 25.0 & 22 & 23.6-28.7 & 26.0 & 1.5 & 32 & $25.0-28.9$ & 26.4 & 1.1 & - \\
\hline Snout to pelvic-fin origin & 46.9 & 22 & 44.3-51.9 & 46.8 & 1.6 & 32 & $45.0-50.3$ & 47.4 & 1.5 & - \\
\hline Snout to anal-fin origin & 57.7 & 22 & $54.7-63.3$ & 59.2 & 1.9 & 32 & $55.6-65.0$ & 61.0 & 1.9 & - \\
\hline Caudal peduncle depth & 17.3 & 22 & $13.1-17.4$ & 15.6 & 1.5 & 32 & $12.8-16.0$ & 14.6 & 1.0 & + \\
\hline Caudal peduncle length & 12.3 & 22 & $08.8-14.8$ & 11.1 & 1.3 & 32 & $08.4-12.1$ & 10.3 & 1.0 & - \\
\hline Pectoral-fin length & 30.8 & 22 & 22.1-33.5 & 27.3 & 3.4 & 32 & $16.8-25.7$ & 23.0 & 2.0 & + \\
\hline Pelvic-fin length & 21.9 & 22 & $13.5-24.4$ & 19.7 & 3.9 & 32 & $13.3-17.3$ & 15.7 & 1.0 & + \\
\hline Dorsal-fin base length & 16.2 & 22 & $13.5-19.1$ & 15.6 & 1.4 & 32 & $12.8-15.9$ & 14.1 & 0.8 & + \\
\hline Dorsal-fin height & 27.7 & 22 & $26.0-29.8$ & 27.3 & 1.3 & 32 & $23.2-28.0$ & 25.8 & 1.1 & + \\
\hline Anal-fin base length & 32.3 & 22 & 29.9-34.5 & 32.2 & 1.2 & 32 & $22.2-33.1$ & 29.2 & 3.3 & + \\
\hline Anal-fin lobe length & 28.9 & 22 & $21.6-29.4$ & 26.1 & 2.4 & 32 & $15.0-26.0$ & 23.3 & 1.9 & + \\
\hline Eye to dorsal-fin origin & 38.8 & 22 & $37.0-44.3$ & 40.1 & 1.9 & 32 & $40.4-45.5$ & 42.5 & 1.5 & + \\
\hline Dorsal-fin origin to caudal-fin base & 55.4 & 22 & 49.3-56.7 & 52.5 & 2.3 & 32 & 48.1-53.4 & 50.1 & 1.3 & + \\
\hline Bony head length & 26.9 & 22 & $26.0-30.2$ & 28.0 & 1.3 & 32 & $27.3-30.7$ & 29.0 & 0.9 & - \\
\hline Horizontal eye diameter & 40.0 & 22 & 36.1-41.9 & 38.3 & 1.7 & 32 & $35.8-41.9$ & 38.9 & 1.6 & - \\
\hline Snout length & 22.9 & 22 & $18.6-23.8$ & 21.2 & 1.5 & 32 & $17.1-23.2$ & 20.2 & 1.4 & - \\
\hline Least interorbital width & 32.9 & 22 & $30.6-36.2$ & 33.4 & 1.4 & 32 & $29.3-34.8$ & 32.6 & 1.3 & - \\
\hline Upper jaw length & 37.1 & 22 & $34.7-42.3$ & 38.1 & 2.3 & 32 & $34.1-38.7$ & 36.7 & 1.2 & - \\
\hline
\end{tabular}

moderately developed lobe anteriorly (Figs. 3, 4 and 6); lobe includes third or fourth unbranched ray and first six branched rays. Anal fin of sexually mature males with hooks distributed on last unbranched ray and anterior five branched rays (Fig. 6). Pectoral-fin unbranched ray i in all specimens, branched rays $11-14$ (12), $12.3, \mathrm{n}=54$; tip of pectoral-fin extends to origin of pelvic fin; fins longer in mature males than in mature females. Middle portions of unbranched and first branched pectoral-fin rays of sexually mature males with thickened lepidotrichia (see Castro et al., 2003: 15, fig. 5). Pelvic-fin rays i, 6 (in all specimens, $n=54$ ). First (unbranched) ray of pelvic fin bearing small hooks (Fig. 7). Principal caudal-fin ray count

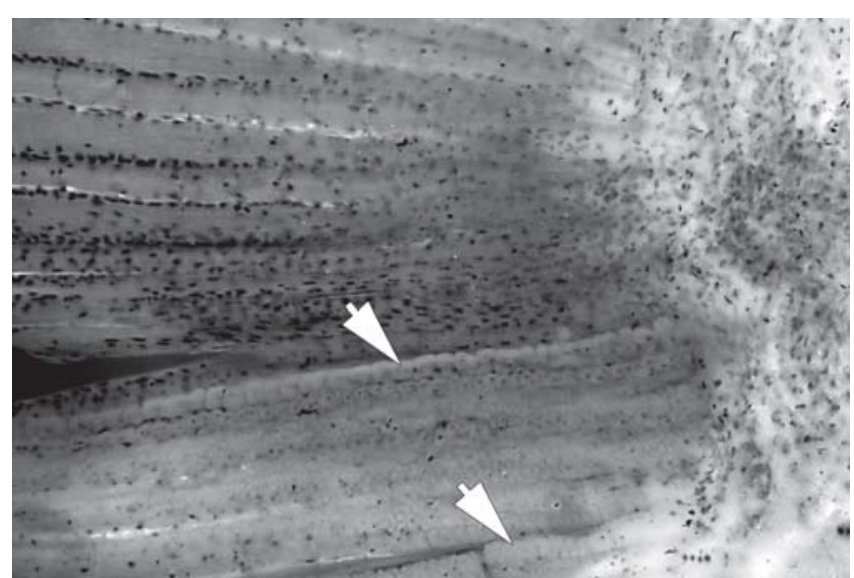

Fig. 5. Lophiobrycon weitzmani, paratype, adult male, MZUSP 83353, SL $26.5 \mathrm{~mm}$ SL; detail of caudal organ showing beaded glandular tissue indicated by arrows.
10/9, $(n=54)$.

Scales cycloid; lateral line incomplete, perforated scales 1-7 (4), 5, $n=54$. Lateral series scales 30-36 (31), 32.7, $n=49$. Predorsal scales $13,12.8, n=50$. Scale rows between dorsalfin and anal-fin origin 12-13 (12), $12.3, \mathrm{n}=54$. Scale rows around caudal peduncle 14-15 (14), 14.4, $n=47$.

Oral teeth form and arrangement as described and illustrated by Castro et al. (2003: 15, fig. 6). Outer row premaxillary teeth 1-3 (2), 1.9, $\mathrm{n}=54$; inner row 5-7 (5), $\mathrm{n}=54$. Maxillary teeth 3-7 (6), 4.4, $n=54$. No significant difference in tooth number between females and males.

Vertebrae 33-35 (34), 34.4, $n=35$. Dorsal limb gill rakers 5-

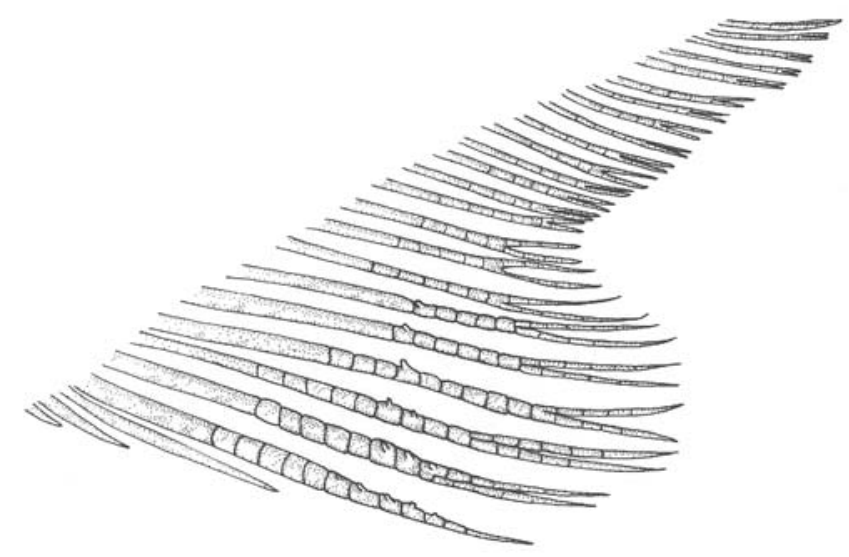

Fig. 6. Lophiobrycon weitzmani, paratype, adult male, LIRP 4338, $33.1 \mathrm{~mm}$ SL; anal-fin rays with hooks, lateral view, left side. 
7 (6), 5.8, $n=54$; ventral limb gill rakers 8-10 (10), 9.3, $n=54$. Branchiostegal rays 4 in cleared and stained specimens, 3 rays originating on anterior ceratohyal and 1 on posterior ceratohyal.

Color. The preserved color pattern of males and females as well as life colors described and illustrated by Castro et al. (2003: 15, figs. 1 and 2).

Sexual dimorphism. In addition to the sexually dimorphic features discussed by Castro et al. (2003: 15-16) males have hooks on at least first pelvic-fin ray that are absent in females and lack urogenital papilla (Figs. 3 and 7). Females have a urogenital papilla with a posterior opening and the anus located at its base (Fig. 8). This papilla is rudimentary in immature females (13.5-16.5 mm SL) and well developed in mature females (18.0-25.0 mm SL). Castro et al. (2003: 15) found differences in body depth, caudal peduncle depth and pectoral-fin length between males and females of $L$. weitzmani with increasing SL as they become sexually mature and increase in length. Our criteria to differentiate males and females led us to a different proportion between sexes than that obtained by Castro et al. (2003). With our results shown in Table 2 only pectoral-fin length and pelvic-fin length showed significant dimorphic differences in regression analysis as shown in Figs. 9 and 10. Males reach greater lengths than the females in the available samples

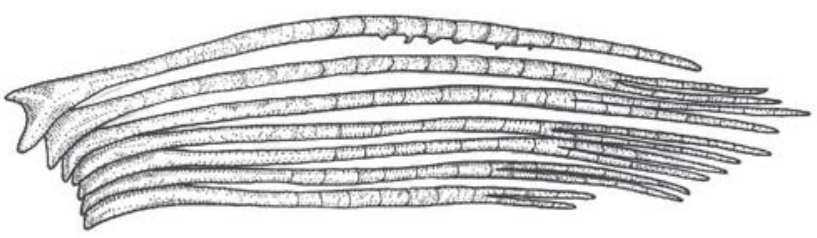

Fig. 7. Lophiobrycon weitzmani, paratype, adult male, LIRP 4338, $33.1 \mathrm{~mm}$ SL; pelvic-fin rays, ventral view, left side, anterior at left.

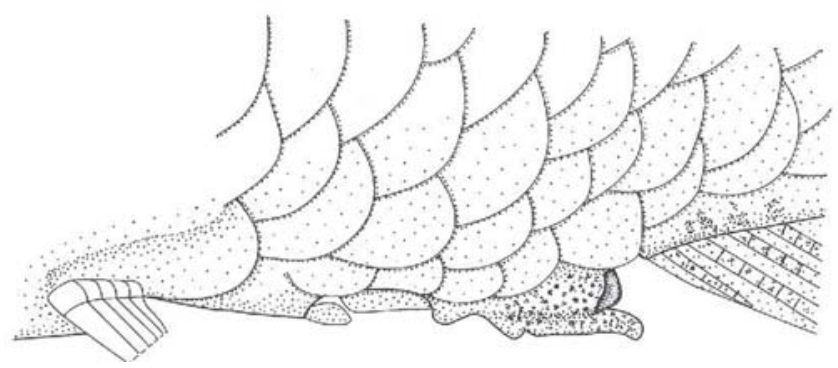

Fig. 8. Lophiobrycon weitzmani, paratype, mature female, MZUSP 83353, $18.2 \mathrm{~mm}$ SL; urogenital papilla of mature female, lateral view, left side, anterior at left.

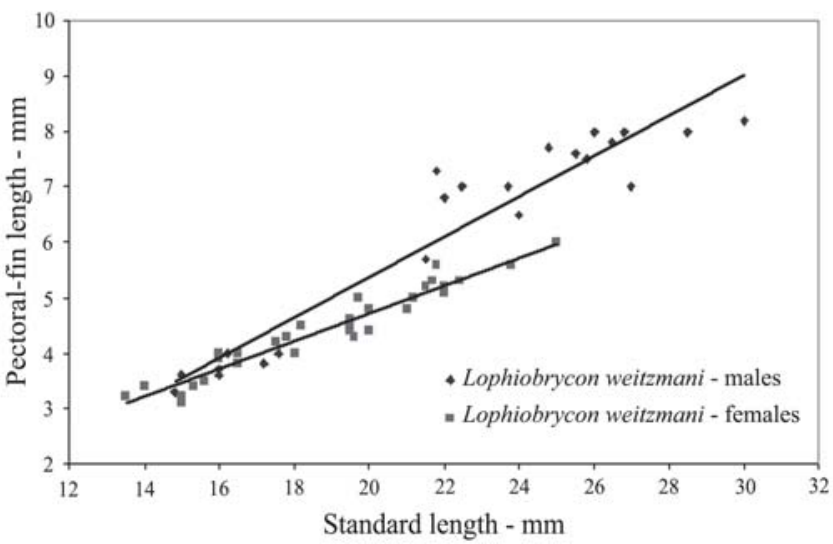

Fig. 9. Lophiobrycon weitzmani. Pectoral-fin length as function of standard length for males and females.

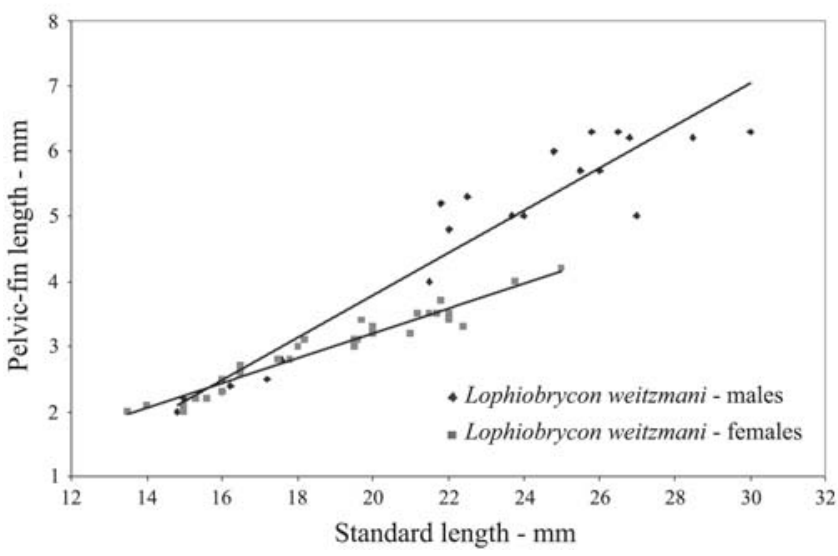

Fig. 10. Lophiobrycon weitzmani. Pelvic-fin length as function of standard length for males and females.

with divergence between the sexes in the two dimorphic characters starting at about $20 \mathrm{~mm}$ SL.

Distribution. Lophiobrycon weitzmani is endemic to headwater streams in the middle stretch of the rio Grande basin in the upper rio Paraná basin. See fig. 3 in Castro et al. (2003), and fig. 3 in Menezes et al. (2008).

Material examined. Holotype. LIRP 4366, male, $26.0 \mathrm{~mm} \mathrm{SL}$, Brazil, Minas Gerais, rio Grande basin, município de Delfinópolis, estância Carmen Sílvia, córrego Bom Jesus, 20¹2'10"S 462' W. Paratypes. Collected with holotype: LIRP 4337, 8, 19.7-27.0 mm SL, 1 male C\&S, 4 adult females, 19.7$22.0 \mathrm{~mm}$ SL, 1 immature male, $27.0 \mathrm{~mm}$ SL, 1 adult male, 25.5 mm SL; LIRP 4338, 8 adult males, 22.0-30.0 mm SL, 4 immature males, 15.0-24.0 mm, 11 adult females, 17.8-25.0 mm SL, 3 immature females, 13.5-16.5 mm SL; MZUSP 83353, 2 adult males, 25.8 and $26.5 \mathrm{~mm}$ SL, 5 immature males, $14.8-17.6 \mathrm{~mm}$ SL, 5 mature females, 18.0-21.2 mm SL, 8 immature females, 15.0-21.8 mm SL. 


\section{Glandulocauda Eigenmann, 1911}

Glandulocauda Eigenmann, 1911b: 168 [type species: Glandulocauda melanogenys Eigenmann (1911b: 168) by original designation. - Eigenmann, 1914: 35 and 42 (in key to genera of Glandulocaudinae). - Eigenmann \& Myers, 1929: 467, 487-490 (followed Eigenmann, 1911b, in allocation of species). - Travassos, 1951b: 66 (listed). - Böhlke, 1958: 43 (followed Eigenmann, 1911a, in allocation of species). Nelson, 1964a: 63-75 (accepted Glandulocauda based on anatomy of $G$. inequalis rather than G. melanopleura). Géry, 1964: 6-9 (placed G. inequalis in Mimagoniates and accepted his new species $G$. terofali as a species of Glandulocauda; tentatively based concept of Glandulocauda on anatomy of G. terofali). - Géry, 1966: 228-299, 235 (G. inequalis separate from Glandulocauda, but did not assign it generic name; retained G. terofali in Glandulocauda). - Géry, 1977: 355-362 (included equivalents of G. melanopleura, G. caerulea, and G. terofali; considered $G$. inequalis to have uncertain status). - Weitzman \& Fink, 1985: 2, 103-109, 109 (assigned only equivalents of $G$. melanopleura and $G$. caerulea to Glandulocauda; removed G. terofali to Diapoma Cope and G. inequalis to Mimagoniates). - Weitzman et al., 1988: 384-413 (followed Weitzman \& Fink, 1985, in assignment of species to genera). - Menezes \& Weitzman, 1990: 384 (followed Weitzman \& Fink, 1985: 2, 103-106, 109; in key to genera and species of Glandulocaudini).

Diagnosis. Glandulocauda can be distinguished from the remaining glandulocaudines by having principal caudal-fin rays 11 and 12 slightly bowed ventrally but not involved in the formation of a fin-ray pump. Glandulocauda additionally differs from Lophiobrycon by having the origin of the dorsal fin just slightly ahead of vertical through anal-fin origin (Figs. 11 and 12), but closer to caudal-fin basin than to snout tip, 1619 scale rows around the caudal peduncle and the lack of a urogenital papilla in females. In Lophiobrycon the dorsal fin origin is considerably ahead of vertical through anal-fin origin (Fig. 3) and closer to snout tip than to caudal-fin base (Fig. 3), the number of scale rows around the caudal peduncle is 1415, and the urogenital papilla is present in females (Fig. 8). From Mimagoniates it differs by having the origin of the dorsal fin slightly ahead of vertical through anal-fin origin (Figs. 1112 and 20-21), adult males with more than one hook on analfin rays that bear hooks (Figs. 16 and 26), and fewer predorsal scales (15-18). In Mimagoniates the origin of the dorsal-fin is posterior to vertical through anal-fin origin (Figs. 30-31, 36, 45-46, 52-53, 63-64, 70-71, and 77-79), the adult males usually have no more than 1 hook on anal-fin rays that bear hooks, sometimes 2 hooks on anterior divided ray and 3 on longest unbranched anterior ray (Figs. 33, 39, 50, 56, 65, 73 and 81) and more predorsal scales (18-28).

Remarks. Live colors of Lophiobrycon weitzmani (see Castro et al. 2003, fig. 2) briefly described by these authors (p.15) differ considerably from those of both species of Glandulocauda and must be autapomorphic for that genus. Adult males of G. melanopleura are predominantly pale yellow admixed with some brownish green; see Weitzman \& Menezes (1994: 4) for color photographs in life. The live body color for G. caerulea is a dark steely blue with apparently some purple added; see Weitzman \& Menezes (1994: 4). This color may not be exactly accurate because we believe the color temperature of the color film used in Weitzman \& Menezes (1994: 4) was not exactly balanced for the light source used. The blue body color found in Glandulocauda caerulea differs from that found in the species of Mimagoniates and is not found in other characids known to us. We suggest that the blue color in G. caerulea is derived and possibly autapomorphic for the species.

\section{Glandulocauda melanopleura (Ellis, 1911) Figs. 11-12}

Hyphessobrycon melanopleurus Ellis, 1911: 157, plate 3, fig. 2, (type locality: “Alto da Serra, São Paulo”, description based on immatures). - Eigenmann,1921: 220, plate 30, fig. 4 (redescription based on type specimens). - Fowler, 1948: 126, fig. 142 (listed).

Glandulocauda melanogenys Eigenmann, 1911b: 168, plate 5, fig. 6, (description, type locality: "Alto da Serra, São Paulo, July 25, 1908”). - Eigenmann, 1914a: 42 (listed). Henn, 1928: 68 (listed in catalog). - Eigenmann \& Myers, 1929: 488 (redescription based on type specimens). - Fowler, 1951: 414 (listed; humeral spots shown too dark). - Böhlke, 1958: 43 (listed characters of species in key to glandulocaudine genera). - Nelson, 1964a: 63 (listed in discussion). - Géry, 1964: 6 [discussed characters listed by Böhlke (1958: 43) regarding relationships of Glandulocauda terofali Géry, 1964]. - Géry, 1966: 229 (in key to males of Glandulocauda and Mimagoniates). - Géry, 1977: 362 (listed in brief discussion of Glandulocauda and Mimagoniates). - Weitzman \& Fink, 1985: 104, 109 [listed in material examined and in discussion of relationships of Diapoma (= Glandulocauda; in part, of Géry, 1964)]. - Ibarra \& Stewart, 1987: 39 (type catalog). - Weitzman et al., 1988: 384-419 (discussion of relationships and biogeography). Menezes \& Weitzman, 1990: 384 (in key to Glandulocaudini). - Vari \& Howe, 1991: 30 (type catalog). Weitzman \& Menezes, 1994: 2 (general description for nonsystematic literature). - Guimarães et al., 1995 (cytogenetic studies). - Weitzman, 2003: 225 (maximum length; distribution; remarks and references). - Machado et al., 2005: 73 (conservation status). - Ribeiro et al., 2006: 158160 (photograph; presence in rio Guaratuba, São Paulo; comments on distribution and relationships). - Menezes et al., 2007: 123 (distribution; systematic status; ecology; conservation status). - Menezes, 2007: 38 (listed in catalog; distribution; conservation status). - Serra et al., 2007: 83-85 (comments on distribution and ecology). - Langeani et al., 


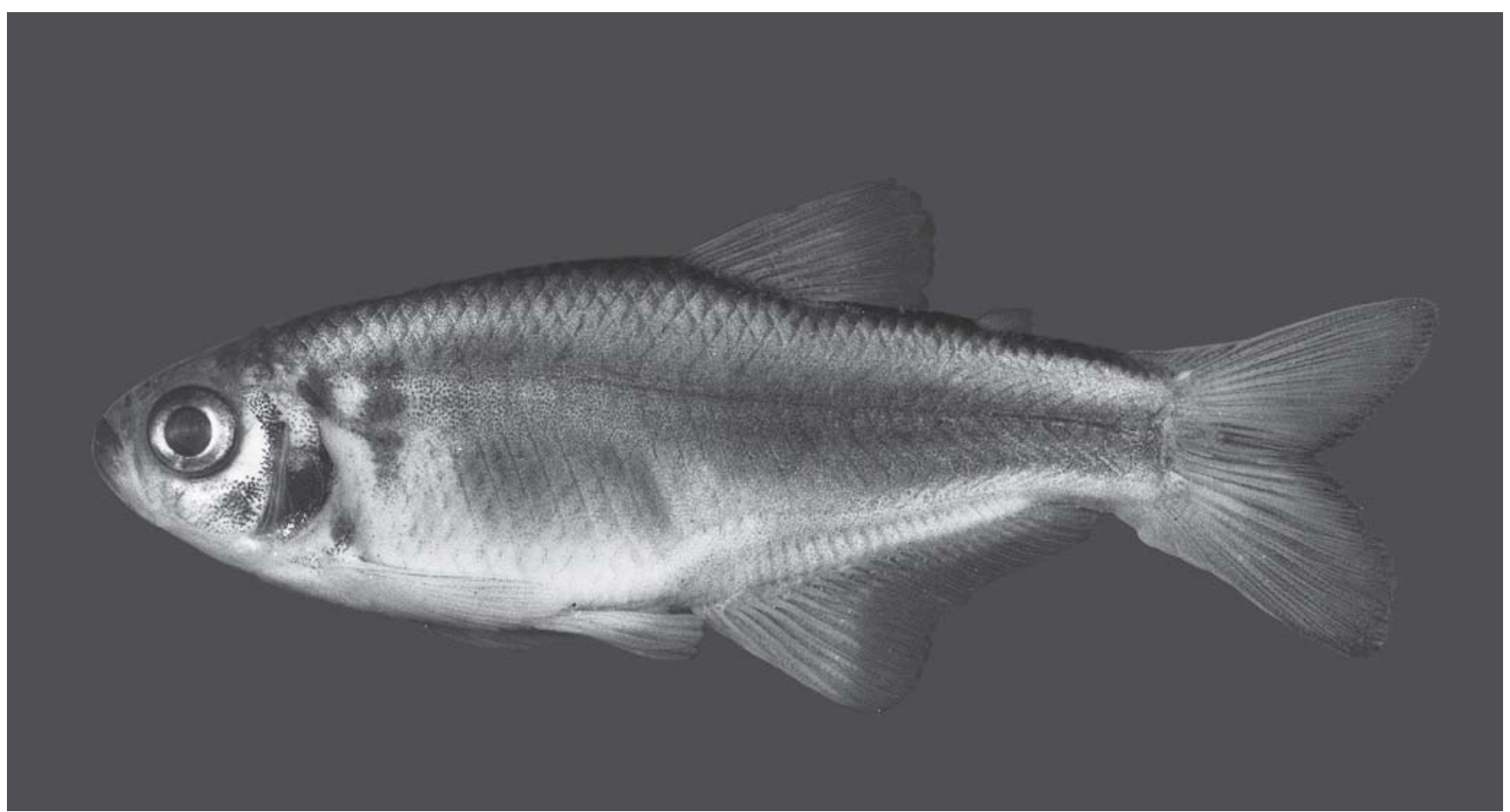

Fig. 11. Glandulocauda melanopleura, adult male. USNM 236415, 42.3 mm SL, Brazil, São Paulo State, headwater stream of rio Tietê near Paranapiacaba. Modified from Weitzman et al. (1988).

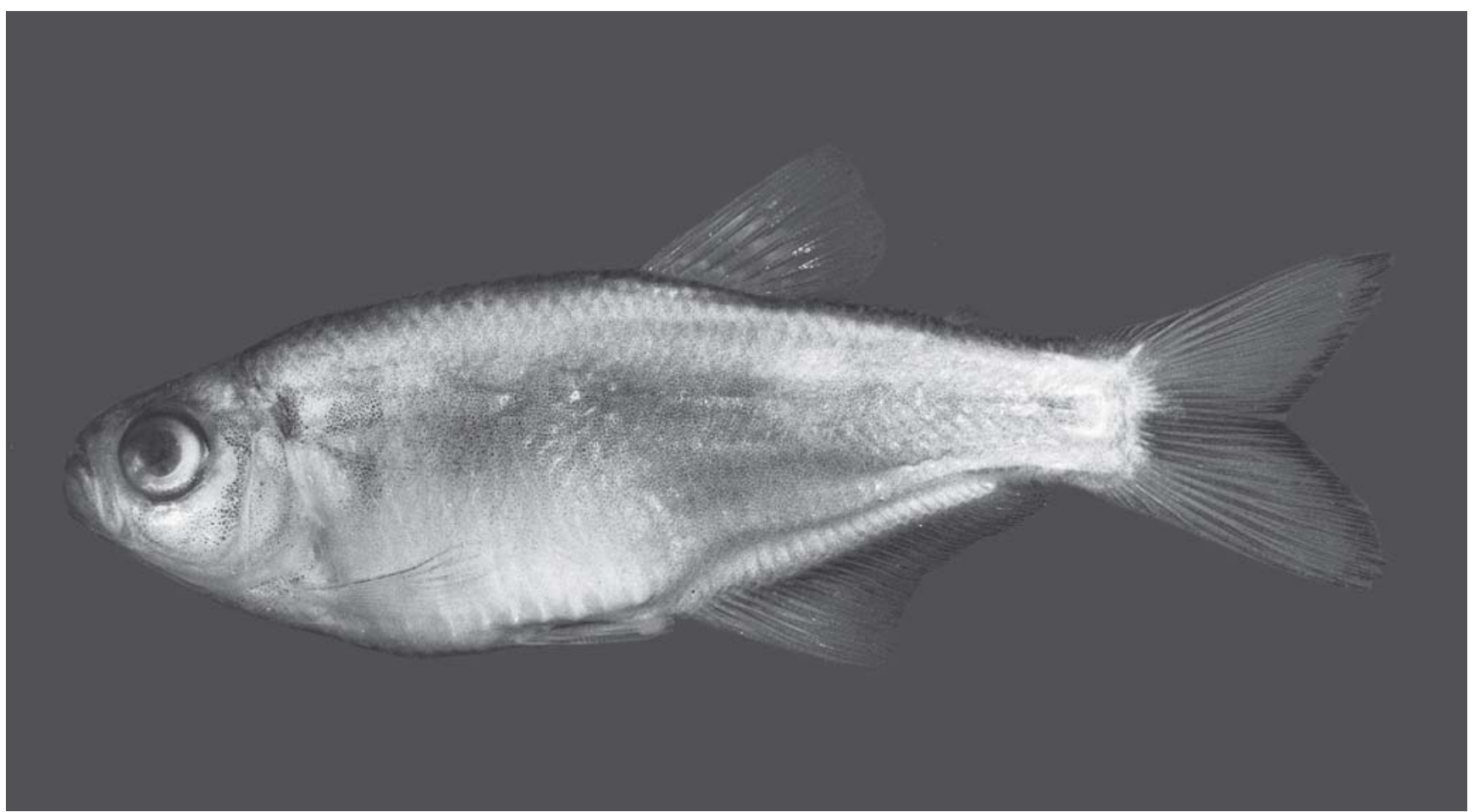

Fig. 12. Glandulocauda melanopleura, adult female. USNM 236415, 37.5 mm SL, São Paulo State, headwater stream of rio Tietê near Paranapiacaba. Modified from Weitzman et al. (1988).

2007: 184 (size; origin and occurrence in upper rio Paraná). Menezes et al., 2008: 37-41 (photograph; distribution; discussion of relationships and biogeography). - Menezes \& Lima, 2008: 63 (conservation status; general informations; geographic distribution; main threats; conservation strategies).

Mimagoniates melanogenys Schultz, 1959: 10 (in key; new generic allocation). See below notes on type locality.

Diagnosis. Glandulocauda melanopleura can be 
distinguished from all the other glandulocaudines except $G$. caerulea by having caudal rays 11 and 12 slightly decurved but not forming a caudal-fin ray pump. From $G$. caerulea it differs by possessing 20-24 branched anal-fin rays (15-18 in G. caerulea), 13-16 horizontal scale rows from dorsal-fin origin to anal-fin origin (11-13 in G. caerulea) and 37-42 lateral series scales (31-35 in G. caerulea).

Description. Table 3 presents morphometrics of examined specimens. Description based on samples from near type locality treated statistically as one population sample other than where noted otherwise. Counts given second in brackets for type of Glandulocauda melanogenys. Body compressed, relatively deep, especially near dorsal-fin origin; body deepest along vertical at point between pelvic-fin and anal-fin origins. Predorsal body profile gently convex to tip of snout (Figs. 11 and 12). Body profile somewhat elevated at dorsal-fin origin, arched in males, less so in females and juveniles. Dorsal profile of body relatively straight along dorsal-fin base to adipose fin. Body profile posterior to adipose fin concave dorsal to caudal peduncle. Dorsal-fin origin nearer to caudal-fin base than to snout tip. Ventral profile of body convex in adult males and females from anterior tip of lower jaw to origin of pelvic fins, convexity less pronounced in juveniles. Abdominal profile in adult males slightly concave between pelvic-fin and anal-fin origins; straight or slightly convex in juveniles and females. Body profile along anal-fin base in both sexes slightly concave to slightly convex at region of anterior lobe of anal fin; more or less straight along remainder of fin. Ventral profile of caudal peduncle anterior to procurrent rays more or less straight or slightly concave.

Lower jaw protruding, extending slightly anterior to upper jaw. Lower jaw of fully adult males thick and heavy compared to that of females and juveniles. Mouth angled posteroventrally. Maxilla long, extending to point well ventral to horizontal drawn from ventral border of eye in all specimens. Maxilla extends posteriorly to anterior to vertical drawn through anterior border of pupil of eye in males, between anterior border of eye and pupil in females and juveniles.

Dorsal-fin unbranched rays ii in all specimens, branched rays 8-9 (8) [8.0], 8, $n=63$; posterior ray not split to its base and counted as 1 ray. Adipose fin not elongate or slender (Figs.11 and 12). Unbranched anal-fin rays iv or v, typically iv, branched rays 20-25 (22) [22], 22.0, $\mathrm{n}=5$ 9. Posterior analfin ray split to its base but counted as 1 ray (Fig. 16). Anal fin with moderately developed lobe anteriorly (Figs. 11, 12, 16); lobe formed by anterior undivided rays and first 4 or 5 divided rays. Anal fin of sexually mature males with bilateral hooks, usually anterior fifth unbranched ray with approximately 10 hooks, 1 hook per segment. First branched ray with approximately 7 hooks, 1 hook per segment. Number of hooks decreasing until sixth or seventh branched ray which bear 1 hook only on each side, all remaining branched fin rays with 1 hook rarely 2 on each side, except last divided ray which bears no hooks. Pectoral-fin unbranched ray i in all specimens, branched rays 9-13 (11) [11], 10.7, $\mathrm{n}=63$. Tip of pectoral-fin extends beyond origin of pelvic fins; pectoral fins of about equal extent in both sexes. Pelvic-fin rays i, 6 [7, anterior ray

Table 3. Morphometrics of Glandulocauda melanopleura. Standard length is expressed in mm; measurements through bony head length are percentages of standard length; the last four entries are percentages head length. A plus sign under the abbreviation dif indicates there is a significant statistical difference between the males and females in the particular character indicated. All specimens are from Campo Grande/Paranapiacaba region, headwaters of rio Tietê, São Paulo: FMNH 54891 (Holotype of G. melanogenys), FMNH 892, FMNH 15025, FMNH 15026; MZUSP 28849, MZUSP 35242, MZUSP 1869, MZUSP 26890, MZUSP 26891, MZUSP 26892; CAS(IUM) 13287; USNM 236414, USNM 236415. SD = Standard deviation.

\begin{tabular}{|c|c|c|c|c|c|c|c|c|c|c|}
\hline \multirow{2}{*}{ Characters } & \multicolumn{4}{|c|}{ Males } & \multicolumn{5}{|c|}{ Females and juveniles } & \multirow[b]{2}{*}{ dif. } \\
\hline & $\mathrm{N}$ & Range & Mean & SD & Holotype & $\mathrm{N}$ & Range & Mean & SD & \\
\hline Standard length & 23 & $26.5-44.6$ & 36.0 & & 37.4 & 40 & $24.5-55.0$ & 33.9 & & \\
\hline Depth at dorsal-fin origin & 23 & $27.0-34.5$ & 31.7 & 1.9 & 34.2 & 40 & $27.0-34.6$ & 30.5 & 1.8 & - \\
\hline Snout to dorsal-fin origin & 23 & $53.3-58.5$ & 55.5 & 1.4 & 57.0 & 40 & $56.0-59.0$ & 55.8 & 1.4 & - \\
\hline Snout to pectoral-fin origin & 23 & $23.6-28.0$ & 25.6 & 1.1 & 26.2 & 40 & $23.2-27.6$ & 25.3 & 1.0 & - \\
\hline Snout to pelvic-fin origin & 23 & $42.7-51.8$ & 44.3 & 2.2 & 43.8 & 40 & $42.1-47.1$ & 44.7 & 1.1 & - \\
\hline Snout to anal-fin origin & 23 & $55.5-61.0$ & 58.2 & 1.5 & 59.1 & 40 & $57.3-62.3$ & 59.2 & 1.3 & - \\
\hline Caudal peduncle depth & 23 & $12.0-18.2$ & 14.7 & 1.6 & 15.0 & 40 & $10.6-16.8$ & 13.4 & 1.3 & - \\
\hline Caudal peduncle length & 23 & $09.7-13.0$ & 11.6 & 0.9 & 10.7 & 40 & $10.0-14.2$ & 11.6 & 1.0 & + \\
\hline Pectoral-fin length & 23 & $20.8-25.3$ & 22.8 & 1.1 & 23.0 & 39 & $19.8-24.9$ & 22.0 & 1.1 & - \\
\hline Pelvic-fin length & 23 & 14.3-18.6 & 16.2 & 1.2 & 16.3 & 39 & $12.3-17.1$ & 15.6 & 0.9 & - \\
\hline Dorsal-fin base length & 23 & $11.3-14.2$ & 12.7 & 0.7 & 12.0 & 40 & $10.0-13.4$ & 12.1 & 0.8 & - \\
\hline Dorsal-fin height & 23 & $22.5-26.5$ & 24.3 & 1.2 & 24.0 & 39 & $20.1-26.8$ & 24.0 & 1.3 & - \\
\hline Anal-fin base length & 23 & $29.0-36.1$ & 33.8 & 1.8 & 35.3 & 40 & $28.5-35.3$ & 32.8 & 1.4 & - \\
\hline Anal-fin lobe length & 23 & $18.1-24.1$ & 21.2 & 1.3 & 18.7 & 40 & $18.1-23.2$ & 20.4 & 1.3 & - \\
\hline Eye to dorsal-fin origin & 23 & $41.0-45.2$ & 42.6 & 1.2 & 43.3 & 40 & $40.0-45.3$ & 42.7 & 1.3 & - \\
\hline Dorsal-fin origin to caudal-fin base & 23 & $46.5-51.7$ & 49.0 & 1.2 & 50.8 & 40 & $46.2-50.8$ & 48.4 & 1.2 & - \\
\hline Bony head length & 23 & $24.4-28.4$ & 25.8 & 1.0 & 26.4 & 40 & $23.7-27.8$ & 26.0 & 1.1 & - \\
\hline Horizontal eye diameter & 23 & $35.5-41.2$ & 38.0 & 1.8 & 37.3 & 40 & $36.1-41.1$ & 38.3 & 1.2 & - \\
\hline Snout length & 23 & $18.5-24.3$ & 21.1 & 1.7 & 18.2 & 40 & $17.1-23.0$ & 19.8 & 1.6 & - \\
\hline Least interorbital width & 23 & $30.0-32.7$ & 31.4 & 0.8 & 33.3 & 40 & $29.7-34.2$ & 32.0 & 1.2 & - \\
\hline Upper jaw length & 23 & $40.0-47.1$ & 45.0 & 1.6 & 45.5 & 40 & $41.6-48.8$ & 45.3 & 1.5 & - \\
\hline
\end{tabular}


branched]. Branching of, first ray variable in population samples at hand; i, 6 in 27 specimens with i, 8 in one specimen; anterior ray branched in 21 specimens. Sexually mature, large adult males with over 300 hooks, many of them minute on rays of each pelvic fin. Principal caudal-fin ray count 10/9 in all specimens $(n=44)$, but reduced in some malformed specimens. Principal caudal-fin rays 11 and 12 modified by being bowed ventrally in association with putative pheromone glandular tissue (Fig. 15). Glandular tissue granular or beaded in appearance, confined to principal caudal-fin rays 10-15 in fully mature males (Figs. 13 and 14).

Scales cycloid, with 5-7 radii along posterior border. Terminal scale of modified caudal-fin series of mature males without complex and increased number of radii (Fig. 15).

Lateral line incomplete (Fig. 11), pored scales 7-27 (7) [12], 13.8, $n=43$. Lateral series scales 37-42 (39) [40], 39.9, $n=40$. Predorsal scales 15-18 (15) [16], 16.8, $n=44$. Scale rows between dorsal-fin and anal-fin origins 13-16 (14) [15], 15.1, $\mathrm{n}=44$. Scale rows around caudal peduncle 17-19 (18) [18], $\mathrm{n}=38$.

Premaxillary teeth in 2 distinct rows (Fig.18). All teeth tricuspid or occasionally quadricuspid in large specimens; smaller specimens with smaller sometimes bicuspid or conical. Outer row teeth 2-5 (3) [5], $\mathrm{n}=36$. Smaller specimens tend to have lower counts. Inner row teeth few 4-5 (4) [4], 4.3, n = 45. Maxillary teeth 3-9 (6) [4], 4.8, range 3-9, larger specimens usually with higher counts, $n=45$. All maxillary teeth (Fig. 18) usually tricuspid in large specimens; small specimens with posterior maxillary teeth conical Dentary with 4, (4 large quadricuspid to pentacuspid teeth in all adult specimens), followed by smaller posterior teeth 5-10 (7) [8], 8.1, number of teeth typically greater in largest specimens. Anterior small teeth of posterior portion of dentary tooth row usually tricuspid but sometimes bicuspid, with posterior teeth conic, $\mathrm{n}=42$ (Fig. 18). Maxillary and dentary teeth shaped much like premaxillary teeth. No significant difference in tooth numbers found between males and females.

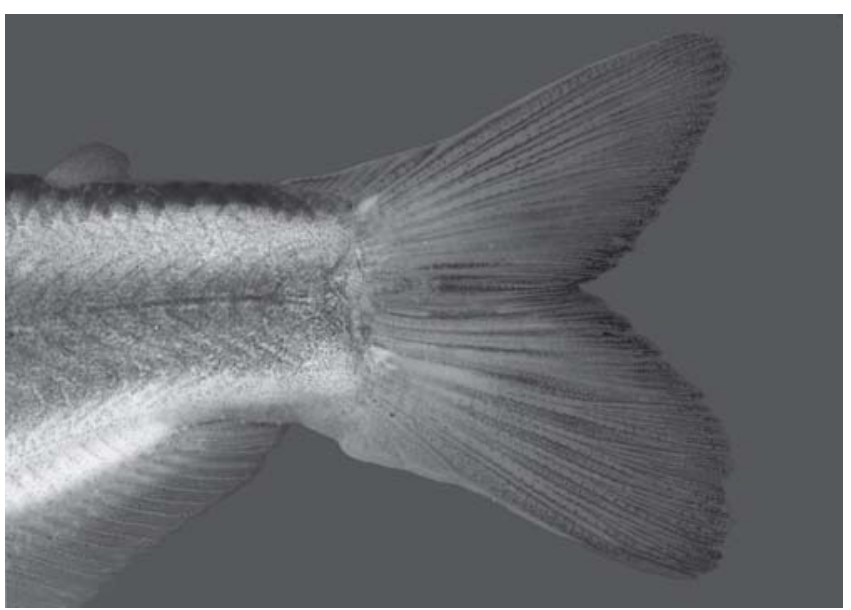

Fig. 13. Glandulocauda melanopleura, adult male, USNM 236415, SL $42.3 \mathrm{~mm}$; caudal fin and caudal peduncle of adult male. Modified from Weitzman et al. (1988).

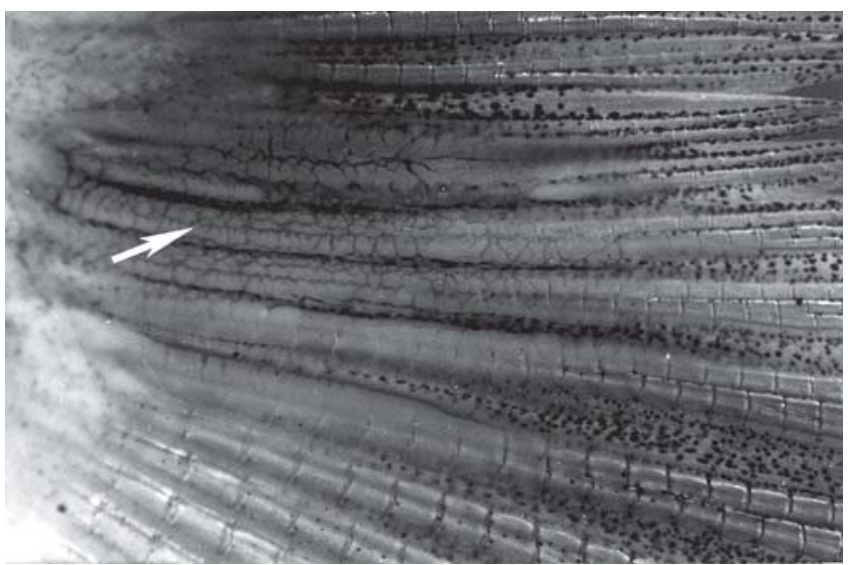

Fig. 14. Glandulocauda melanopleura, adult male, USNM 236415, $42.3 \mathrm{~mm}$ SL: detail of caudal organ showing beaded glandular tissue indicated by arrow. Lateral view, left side. Modified from Weitzman et al. (1988).

Vertebrae 36-38 (36) [37], $\mathrm{n}=45$. Dorsal limb gill-rakers 58 (5) [7], $n=44$; ventral limb gill rakers 9-13 (10) [11], $n=44$. Branchiostegal rays 4 in 2 cleared and stained specimens; 3 rays originating on anterior ceratohyal and 1 ray from posterior ceratohyal.

Color in alcohol. See Figs. 11 and 12 for preserved color patterns of males and females. Color description of preserved adults from specimens collected within last 20 years. Color pattern of types of $H$. melanopleurus faded but dark narrow stripe along body sides illustrated by Ellis (1911: plate III) still visible. Color patterns of the types of G. melanogenys is too faded for useful description, but appears comparable to those of $G$. melanopleura. Body pale to medium brown, pale yellowish brown ventrally, somewhat darker dorsally. No obvious discrete lateral body stripe present in adults but a diffuse brown pigment on body sides of males darker along body midsides as shown in Fig. 11. Female (Fig. 12), with same but paler pigment. Vertically elongate humeral spot present, paler in female than in male. Dark spot present at dorsal termination of gill opening and separated from humeral spot by clear area. Dorsal body surface dark brown, forming a stripe extending from supraoccipital region to base of dorsal procurrent rays of the caudal fin. Remainder of body surface ventral to diffuse lateral body stripe pale brown.

Pectoral and pelvic fins hyaline with a few scattered dark chromatophores. Dorsal, anal, and caudal fins dusky with scattered dark chromatophores along their fin rays and membranes. Anal fin with dark, diffuse, elongate stripe running length of base of fin. This is darker posterior to anterior analfin lobe. Stripe's width about one fourth height of anal fin anteriorly and about one half fin's height posteriorly. Distal part of anal fin hyaline but appears dark in Fig. 11 due to background color in photograph. Anterior anal-fin lobe hyaline. Dorsal-fin, adipose fin, and caudal fin dusky with scattered dark chromatophores. Dorsal border of first principal 


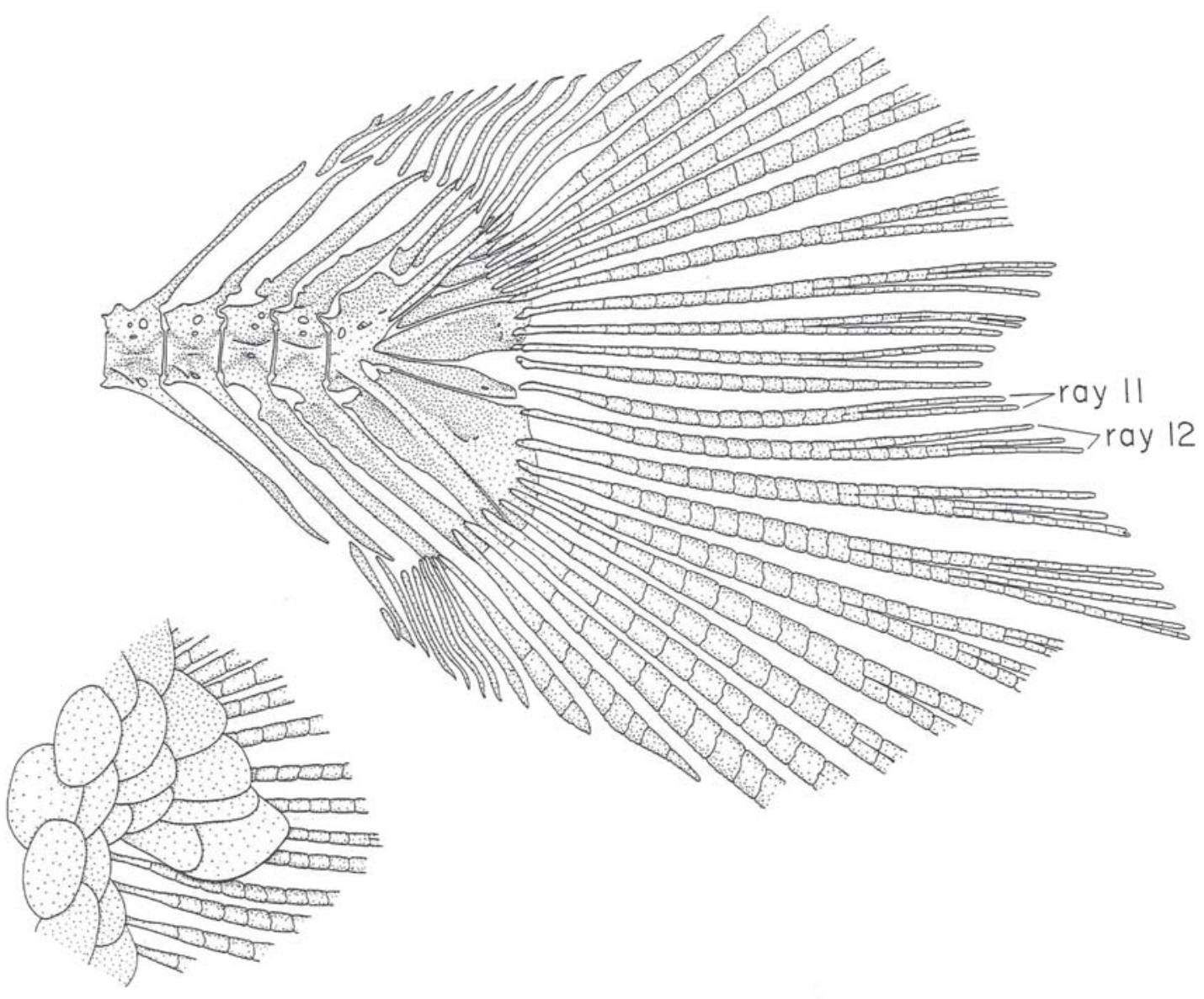

Fig. 15. Glandulocauda melanopleura, adult male, USNM 236093, $40.2 \mathrm{~mm}$ SL; osteology of caudal skeleton and caudal-fin squamation of dorsal portion of caudal-fin lobe (lower left insert), lateral view, left side, anterior at left. Modified from Menezes \& Weitzman (1990).

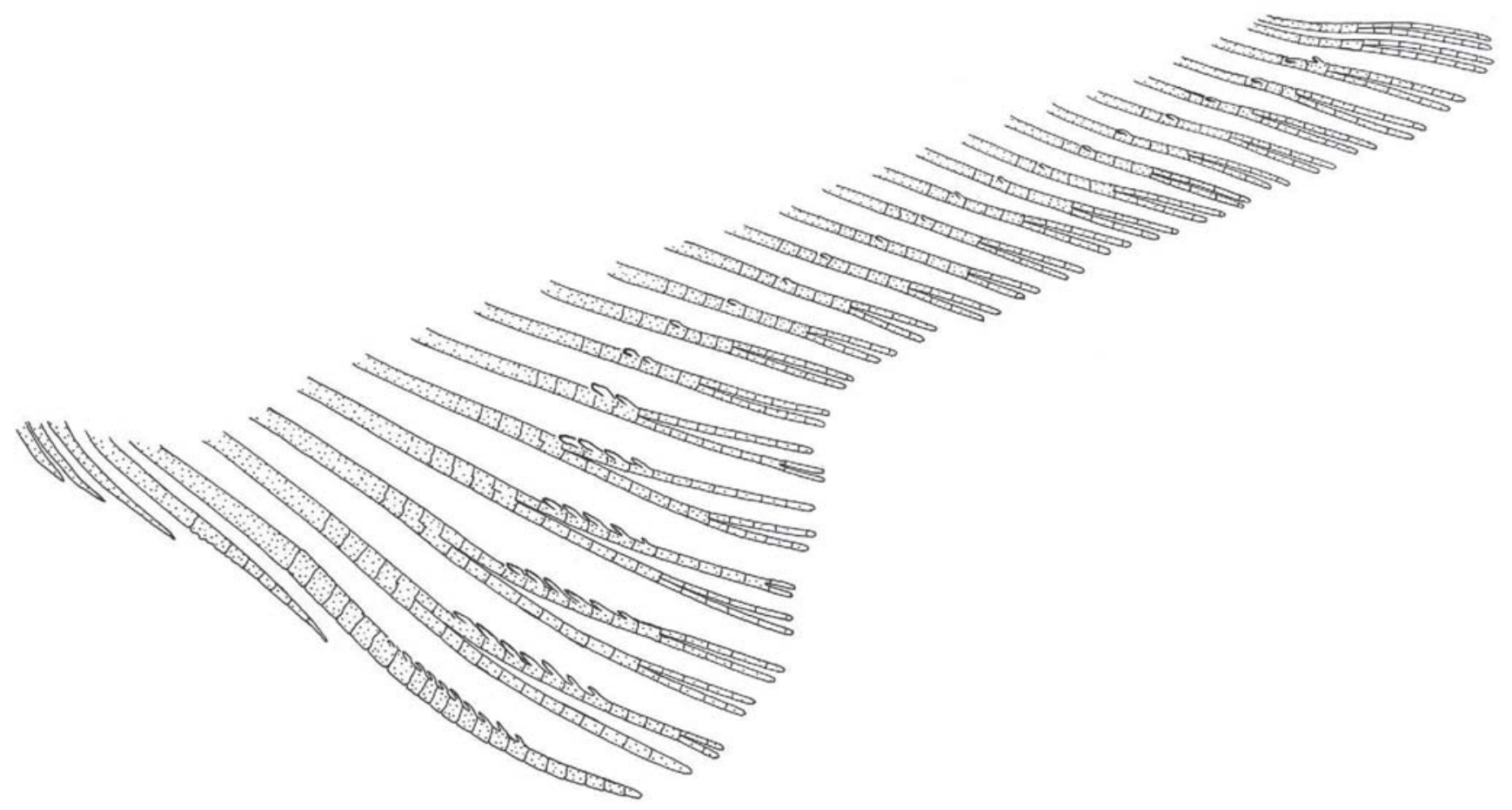

Fig. 16. Glandulocauda melanopleura, adult male, USNM 236415, $42.6 \mathrm{~mm}$ SL; anal-fin rays, lateral view, left side. 


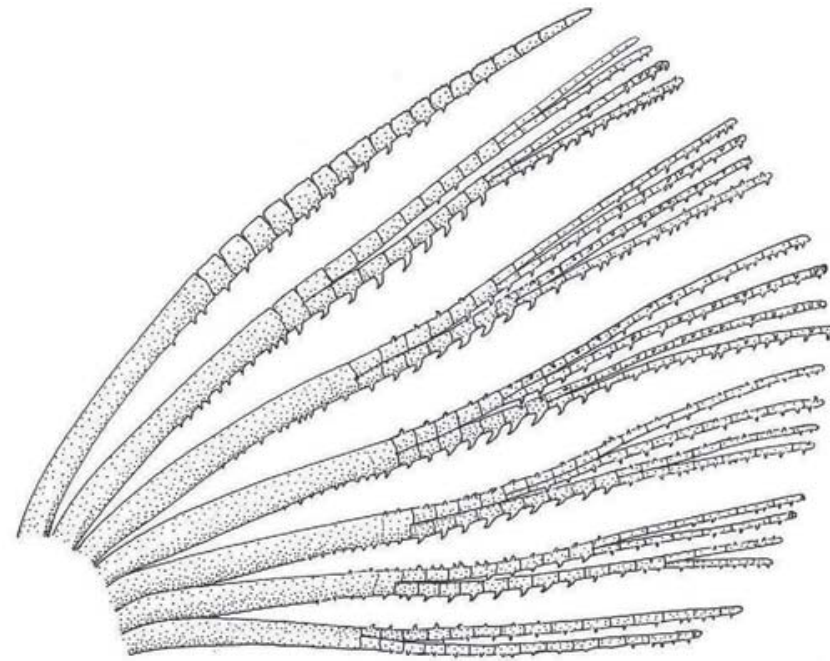

Fig. 17. Glandulocauda melanopleura, adult male, USNM 236415, 42.6 mm SL; pelvic-fin rays, ventral view, left side, anterior at left. First pelvic ray not divided at its distal tip although so divided in some specimens of species.

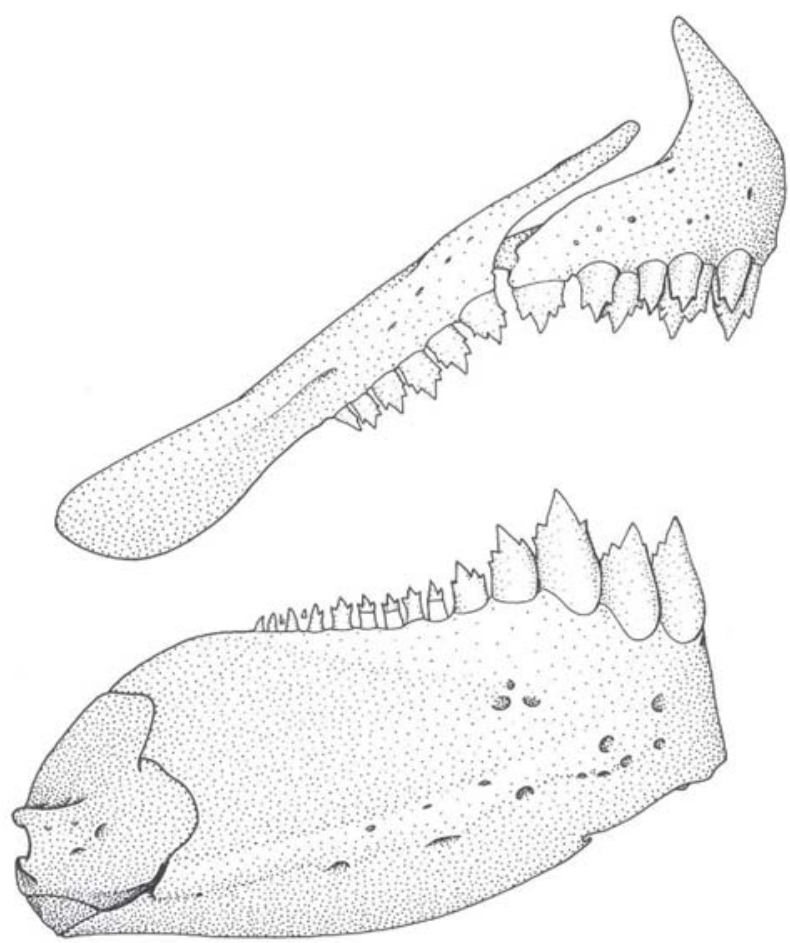

Fig. 18. Glandulocauda melanopleura, adult male, USNM 236415, $42.6 \mathrm{~mm}$ SL; jaws and dentition, lateral view, right side, anterior at right.

caudal-fin ray and ventral border of nineteenth principal caudal-fin ray black. Posterior borders of dorsal and ventral lobes black in both sexes (compare Figs. 11 and 12). Fin-ray membranes in the area of caudal glandular tissue, especially that between rays 7-14 black with dark chromatophores. Dark chromatophores also present between rays 14-19. This pigmentation occurs in adults of both sexes.

Head dark brown around mouth and on dorsal surface of snout, between eyes, dorsum of cranium and nape. Mental area of lower jaw brown. Head area posterior to infraorbitals and extending ventrally from parietal region across dorsal opercular region dark brown to brown in both sexes. Dark area continues ventrally across posterior region of orbital bones and occurs on posterior region of opercle reaching interopercular bone. In Fig. 11, ventral half of opercle of male is covered with very dark chromatophores. Exposed area of cleithrum dark brown. Iris dorsal to pupil dark brown, most of remainder of iris silvery. Infraorbitals silvery if guanine is preserved, pale yellowish brown if guanine is absent.

Color in life. Life colors described here taken from color slides made of live adult sexually-active males and females from just east of Campo Grande, São Paulo State, 7 October 1977. Specimens photographed alive in a small aquarium immediately after capture from clear water stream discussed in section on ecology.

Sides of body are pale silvery tan with lateral body stripe hardly noticeable, but area of stripe is somewhat deeper brown and in part underlain by guanine. Body weakly translucent. Humeral spot or blotch not evident. Body scales not posteriorly bordered in black, being translucent. Body lacks blue pigment. Lateral body stripe weakly present at junction of epaxial and hypaxial muscles. Pigment of lateral body stripe about one to two scales wide and appears deep, internal to skin. This mostly due to presence of dark chromatophores close to muscle tissue. Stripe mostly ends posteriorly at about posterior termination of penultimate vertebra. Caudal peduncle posterior to this area sometimes almost without pigment. Back dorsal to lateral body stripe light brown. Dorsal region of caudal peduncle colored the same as back. Ventral abdominal area, most of lower jaw, ventral opercular area, branchiostegal rays, and their membranes silvery white. Lateral region of opercle translucent and therefore appears red due to blood in gills. Dark pigment of head similar to that described for preserved specimens except that dorsal region of opercle and anterior end of body stripe silvery green. Most areas of head similar to back in color. Brain easily seen through translucent head and appears golden. Lower jaw with pale brown to sometimes dark brown band extending through mental region. Caudalfin lobes bordered in black and non-black areas of fin rays (but not the membranes) colored pale brick red. This red pigment usually darker in males. Region equivalent to pheromone organ in other species of the Glandulocaudinae not colored black or at least not as black as in species of Mimagoniates. However, a small amount of black pigment is present on principal caudal-fin rays 10 and 11 . Anal fin with distal portion of anterior anal-fin lobe yellow to orange, of deeper color in males than in females. Yellow to orange color covers approximately distal halves of posterior undivided ray and anterior 4 or 5 branched rays. Distal ends of branched rays posterior to anal-fin lobe tipped with black 
and some specimens with broad, more or less mottled black band at the distal border of the anal fin posterior to the anterior lobe. Basal region of anterior 5 or 6 divided anal-fin rays colored by narrow black band often suffused with orange or brick red. Remainder of fin hyaline. Pelvic fins yellow to orange, including skin covering distal portion of pelvic girdle. Pectoral fins yellow to orange, darkest in males. Pectoral and pelvic fins otherwise hyaline. Dorsal fin hyaline, yellowish in females and males but males with dusty black longitudinal stripe through their mid length. Distal ends of dorsal-fin rays dusty black.

Types of Hyphessobrycon melanopleurus not faded as types of Glandulocauda melanogenys. Immature specimens of $H$. melanopleurus still display a color pattern similar to that illustrated in the somewhat retouched photograph in Ellis (1911: plate III, fig. 2) in which a dark, narrow lateral band extends from dorsal corner of gill slit posteriorly onto caudal fin. Types of $H$. melanopleurus differ in having dark chromatophores of anterior half of dark lateral stripe darker and more concentrated into a narrow rather well defined stripe, whereas in recently collected specimens the chromatophores in this area more diffuse and lighter. We examined closely at some paratypes of G. melanogenys (FMNH 15025) which have retained their color better than its other types and were able to detect some of same differing color pattern as found in types of $H$. melanopleurus. No other differences were found in other examined features.

We conclude that these specimens are conspecific and that color pattern differences may be correlated with seasonal variation in color pattern at the time and preservation.

Sexual dimorphism. Females lack glandular caudal tissue found in males (compare Figs. 11 and 12). Although females and juveniles have the modified caudal squamation of the males (Fig. 12), their modified scales are smaller and less obvious. Furthermore, females completely lack the anal- and pelvic-fin hooks found in males.

Live color pattern differences of males and females from type locality in breeding condition and collected from type locality are similar overall. Breeding males have intensely orange-golden pectoral fins while those of females are pale orange to pale yellow. Males usually with more red on the caudal-fin rays than females and in some specimens this pigment is concentrated and relatively intense in central areas of each caudal-fin lobe. Males usually with more intense yellow or pale orange color in distal portion of anterior anal-fin lobe, pelvic fins and dorsal fin. Otherwise sexually mature specimens of both sexes have same coloration.

Among the statistically significant sexually dimorphic morphometric characters indicated in Table 3, only caudal peduncle depth proved to be different through regression analysis. Linear regressions prepared for males and for females plus juveniles passed all tests for the linear regression model. Figure 19 indicates that males reach greater lengths than the females and that there is a divergence in caudal peduncle depth between males and females beginning at about $38 \mathrm{~mm} \mathrm{SL}$.

Distribution. Glandulocauda melanopleura is known from the upper rio Tietê area of the upper Paraná basin and adjoining upper portions of the coastal rivers Guaratuba, Itatinga and Ribeira de Iguape flowing into the Atlantic Ocean in the State of São Paulo, Brazil. See fig. 3 in Menezes et al. (2008) as Glandulocauda melanogenys.

Remarks. Three large females (MZUSP 26891), 21 specimens (MZUSP 48511) collected from córrego Mutuca, and 1 specimen out of 7 collected in Campo Grande, São Paulo State, of $G$. melanopleura have the branched anal-fin rays in the range of those for $G$. caerulea, 17, 18 and 19. These specimens however, are very similar to the specimens of $G$. melanopleura with respect to all the other meristic and morphometric characters. We did not include them in our data sets until more specimens from these locations are available for a more detailed analysis.

Three specimens of G. melanopleura recently collected from a tributary of the rio Ribeira drainage (MZUSP 79429) represent the first record of the species outside the upper Tietê drainage.

Ten specimens from a small tributary of rio Guaratuba which empties into the Atlantic Ocean (MZUSP 84412) have branched rays counts $(18-20$, mean $=18.6)$ with lower values and counts of longitudinal scale rows from dorsal-fin origin to anal-fin origin $(16-17$, mean $=16.6)$ and scales around caudal peduncle $(18-20$, mean $=19.3)$ with higher values than those for specimens from the type-locality or near it, respectively 20-25 $($ mean $=22.00), 13-16($ mean $=15.1)$ and $17-19($ mean $=$ 18.0). Since the ranges overlap and all the other meristic and morphometric characters of these specimens are very similar to those of the specimens of G. melanopleura from the type locality or near it we prefer to consider both samples conspecific until more specimens from rio Guaratuba are

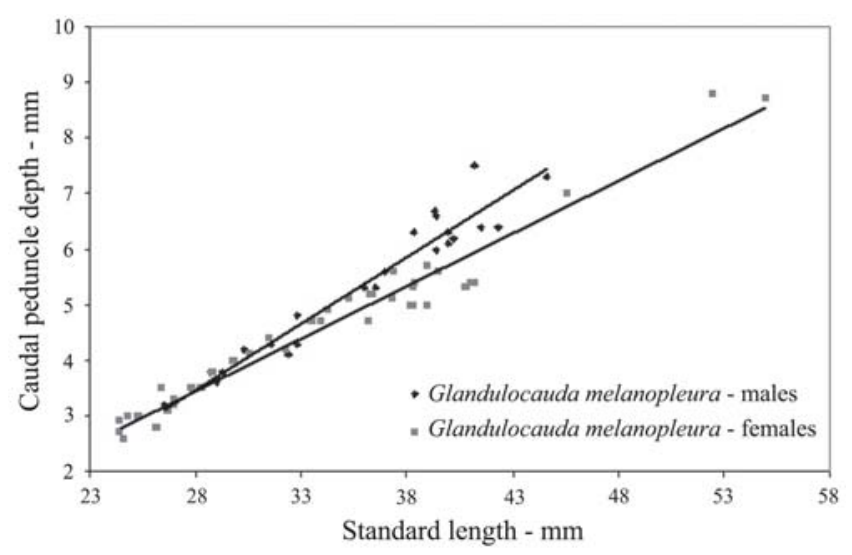

Fig. 19. Glandulocauda melanopleura, caudal peduncle depth as function of SL by sex. Plots illustrate difference between sexes in this feature. See text under sexual dimorphism for further explanation. 
available for study. Two specimens from the rio Itatinga, Parque das Neblinas, São Paulo, were identified as $G$. melanogenys (Serra, Carvalho \& Langeani, 2007), but we not examined this sample. Other populations of G. melanopleura with variations in number of anal-fin rays and a few other meristic counts are likely to be discovered (see discussion in Menezes et al., 2008). We tentatively consider all these populations $G$. melanopleura until more specimens permits more detailed analyses.

Notes on ecology and conservation. This species has been recently collected from its type locality, Alto da Serra and nearby ecological reserves or stations. It apparently is confined to the upper reaches of the upper rio Tietê adjacent river basins, especially in forested areas and was recently considered vulnerable in the State of São Paulo (Menezes \& Lima, 2008). The portion of this stream, where the fish is known to occur, between and near Paranapiacaba, SP, and Campo Grande, SP, is much limited in downstream length by the dammed up waters of the artificial lake, the represa do Rio Grande. Glandulocauda melanopleura apparently requires a stream environment with cool flowing water for successful reproduction and is not known from the lake.

The area where Glandulocauda melanopleura survives, about 750 meters in elevation, was originally mostly a tropical pluvial submountain forest. Except for areas within the Estação Biológica de Boracéia and Reserva Biológica de Paranapiacaba, it is now partly cleared for farming and for railroad yards. Although the area near the stream occupied by G. melanopleura is still forested it is being cleared to accommodate summer homes. Pollution from these homes or the railroad could result in the extinction of the fish in the area.

The populations of G. melanopleura may already be suffering from the effects of pollution. The local air pollution from Cubatão, SP, water pollution from a chlorine plant a few kilometers downstream from Campo Grande, SP, and/or occasional pollution from railroad freight cars since late in the last century may account for the relatively high number (total 8 out of 84 specimens) of deformed individuals in our collections.

Notes on type locality. The locality Alto da Serra was collected by John D. Haseman while travelling through eastern Brazil by train in 1908 but does not appear on modern maps. An old railroad map of Brazil in the Harvard University, "Mappa Ferroviario, Edição 1917”, shows Alto da Serra where today Paranapiacaba is located. The American Geographical Society Map of Hispanic America, section “S. F-23, Rio de Janeiro", provisional edition for 1938 shows Alto da Serra at $23^{\circ} 45^{\prime} \mathrm{S}$ $46^{\circ} 20^{\prime} \mathrm{W}$, approximately the location of Paranapiacaba today. In 1975 we found a metal sign, bearing the words Alto da Serra, which was partly broken away but still attached to an old railroad station at what is now Campo Grande, SP. We are unable to explain the presence of this sign at what today is Campo Grande, SP, 8 km west of Paranapiacaba, SP, since both Campo Grande and Alto da Serra appear on old railroad maps of Brazil. Perhaps Haseman collected at Campo Grande and reading the sign "Alto da Serra" entered that as his locality. According to Eigenmann (1911a: 305) Haseman's notes stated that this locality was characterized by "Small rills with an abundance of algae and reeds". This description could apply to either locality but it best fits Campo Grande where there are several small streams. The stream at Paranapiacaba consists of one small stream with a few small tributaries. We, thus, lean towards Campo Grande, SP, as the type locality; however, the possible confusion is because the main headwater stream involved begins just north of Paranapiacaba then flows through Campo Grande, SP. The species in question is present at both localities and areas in between, albeit today more abundant at Campo Grande, SP, where the stream is not as steep on more level ground and is deeper and slower. See ecological notes.

Material examined. Holotype of Hyphessobrycon melanopleurus. FMNH 54413, immature, 23.4 mm SL, Brazil, São Paulo, município of Santo André, Alto da Serra, headwaters of rio Tietê, approximately

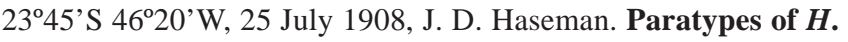
melanopleurus. Collected with holotype: FMNH 54414, 2 immatures, 25.5-26.8 mm SL. Holotype of Glandulocauda melanogenys. FMNH 54891, adult male, $37.4 \mathrm{~mm}$ SL, same type locality and date of collection as for $H$. melanopleurus above. Paratypes of G. melanogenys. Collected with holotype: FMNH 15025, 1 immature male, 31.3 mm SL; FMNH 15026, 1 adult male, 35.0 mm SL; FMNH 54892, 5 males, 4 females, immature to adults, 25.3-40.2 mm SL, 5 juveniles, 23.3-25.4 SL; USNM 177724, 2 immature and adult males, 32.1-40.0 mm SL; CAS(IUM) 13287, 2 immature and adult females, 33.5-36.2 mm SL. Non-Types. All collected in Brazil. São Paulo State, município de Santo André: MZUSP 1869, 4 males, 3 females, adults, 36.3-44.6 mm SL, Campo Grande; MZUSP 26891, 3 adult females, 45.6-55.0 mm SL, Reserva Biológica de Paranapiacaba, Universidade de São Paulo; MZUSP 26890, 1 immature, 30.6, 3 adult females, 39.0-41.0 mm SL, 2-3 km north of Campo Grande, headwaters of rio Tietê; USNM 236414, 1, adult female, $41.2 \mathrm{~mm} \mathrm{SL}$, approx. 1/2 distance between Campo Grande and Paranapiacaba, headwaters of rio Tietê, approx. 234ㅇ's 46²19’W; USNM 236415, 2 males \& 4 females, adults, 32.8-42.3 mm SL, Campo Grande, head waters of rio Tietê; USNM 236093, 2 cleared and stained, 1 adult female and 1 male, adults, 39.3-40.2 mm SL, same data as preceding collection; MZUSP 26892, 2 males and 1 female, adults, 32.8-38.3 mm SL, (1 male abnormal with ventral caudal region reduced in size, not counted or measured), same data as USNM 236415; MZUSP 35242, 7 adult females and males, 36.0-40.2 mm SL, 1 immature female, $34.3 \mathrm{~mm}$ SL, stream near Paranapiacaba; MZUSP 28849, 10 immatures, 26.9-32.7 mm SL, stream tributary to rio Grande, Campo Grande. Following two lots collected in Brazil, São Paulo State, município of Salesópolis, Estação Biológica de Boracéia; MZUSP 48511, 5 juveniles, 19.524.3 mm SL, 6 immature to adult females, 29.0-39.2 mm SL, córrego Mutuca, $23^{\circ} 40^{\prime}$ 'S 455' $\mathrm{W}$; adult MZUSP 84412, 7 immature to males, 25.0-39.4 mm SL, 3 immature females, 20.5-29.8 mm SL, córrego tributary of rio Guaratuba, Trilha do Mirante, Estação Biológica de Boracéia, 2340’8.5”S 4553'55.1”W; MZUSP 79429, 2 males and 1 female, adults, 37.5-51.0 mm SL, stream tributary of rio Juquiá flowing into rio Ribeira drainage, fazenda Santa Rita, município de Juquitiba, 2357’51.5”'S 4656’20.7”W. 


\section{Glandulocauda caerulea, new substitute name}

Figs. 20-21

Glandulocauda melanopleura Eigenmann, 1911b: 170, plate 5, fig. 7 (type locality: "Serrinha, Paraná, rio Iguassu”, Dec 22, 1908). - Eigenmann, 1914a: 42 (listed). - Henn, 1928: 68 (listed in type catalog). - Eigenmann \& Myers, 1929: 489 (redescription based on type specimens). - Böhlke, 1954: 267 (discounts close relationship with Planaltina). - Böhlke, 1958: 43 (listed). - Nelson, 1964a: 63 (listed in discussion). Géry, 1964: 6 (mentioned that species might belong in distinct genus). - Géry, 1966: 229 (in key to males of Glandulocauda and Mimagoniates). - Géry, 1977: 362 (listed in brief discussion of Glandulocauda and Mimagoniates). -
Weitzman \& Fink, 1985: 104 [listed in material examined and in discussion of relationships of Diapoma terofali (Géry, 1964)]. - Godoy, 1987: 137 (as occurring in "rio Iguassu e nos seus afluentes: rios Jangada, Timbó, Canoinhas e Negro" in Santa Catarina; see also Godoy, 1979: 11). Except for specimens from rio Canoinhas, we cannot confirm these records. - Ibarra \& Stewart, 1987: 39 (listed in type catalog). - Weitzman et al., 1988: 401-419 (discussion of distribution and biogeography). - Menezes \& Weitzman, 1990: 384 (in key to Glandulocaudini). - Weitzman \& Menezes, 1994: 3 (general discussion for non-systematic literature). - López et al., 2002: 59 (listed). - Weitzman, 2003: 225 (maximum length distribution; remarks and references). - Ingenito et al., 2004 (comments on collections made in the Paraná State;

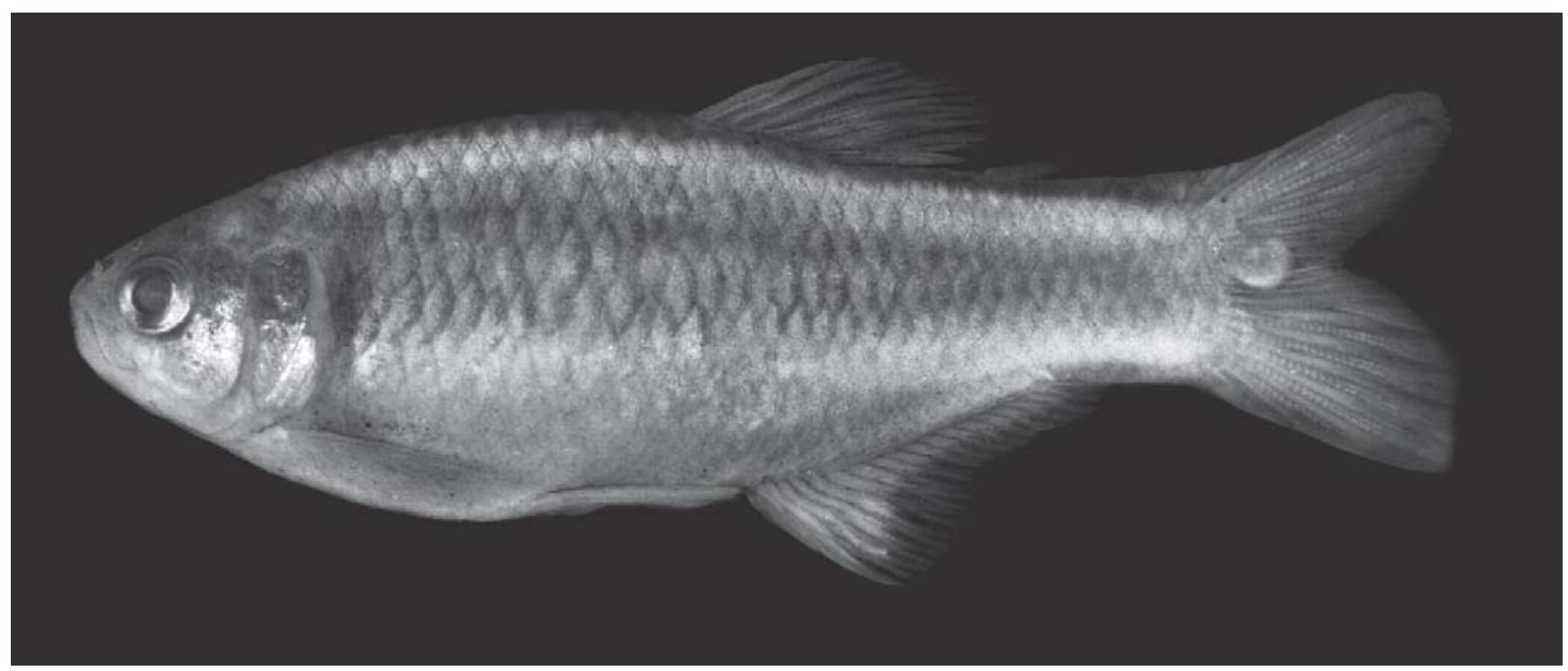

Fig. 20. Glandulocauda caerulea, adult male, USNM 326756, 43.9 mm SL, Brazil, Paraná State, brook tributary to rio Iguaçu near Lara Maria Ranch.

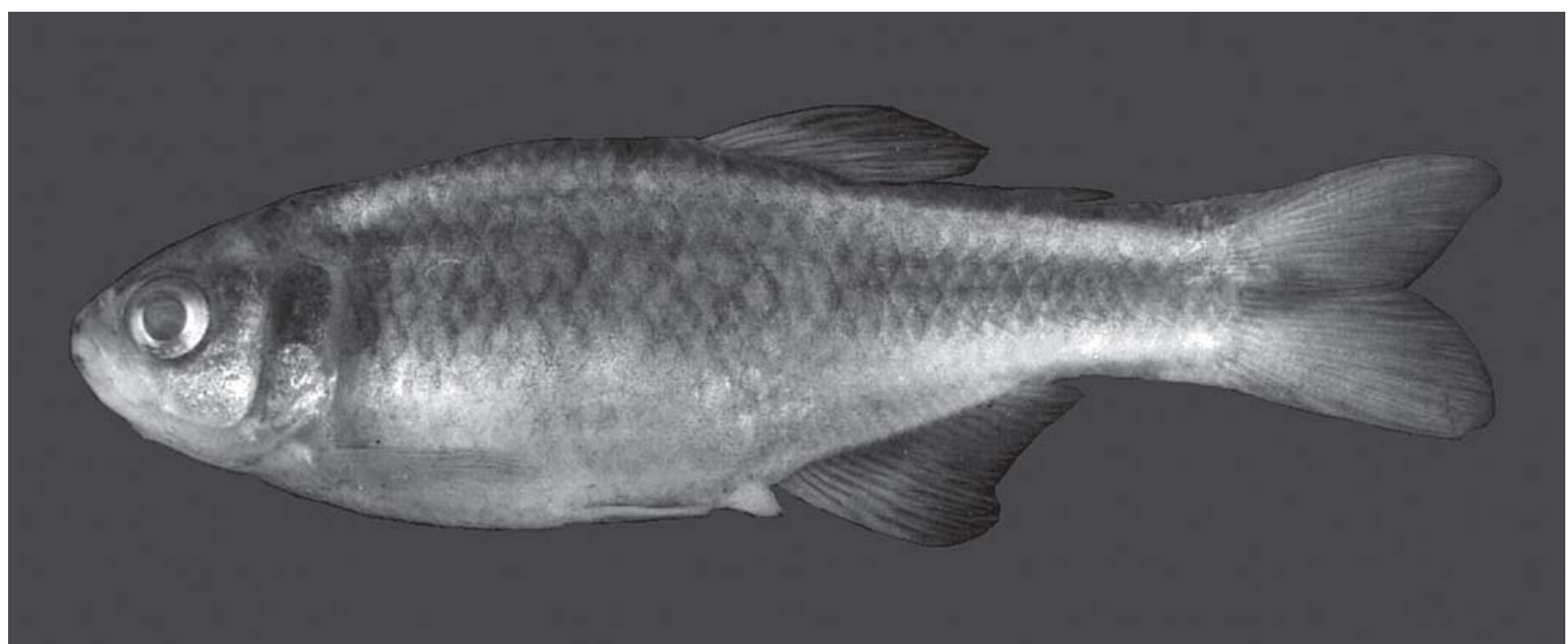

Fig. 21. Glandulocauda caerulea, adult female, USNM 326756, 41.0 mm SL, Brazil, Paraná State, brook tributary to rio Iguaçu near Lara Maria Ranch. 
conservation status). -Machado et al., 2005: 73 (conservation status). - Ribeiro et al., 2006: 160 (listed in discussion). Serra et al., 2007: 38 (listed in discussion). - Menezes, 2007: 38 (listed in catalog; distribution; conservation status). Menezes et al., 2008: 38-41 (distribution, discussion of relationships and biogeography).

Mimagoniates melanopleura Schultz, 1959: 8, 9 (in key, generic allocation). - Duboc \& Menezes, 2008: 63 (conservation status; general informations; geographic distribution; main threats; conservation strategies).

Diagnosis. Glandulocauda caerulea and G. melanopleura are the only glandulocaudines having principal caudal-fin rays 11 and 12 ventrally curved, but not forming a caudal pump. Glandulocauda caerulea can be distinguished from $G$. melanopleura by the number of branched anal-fin rays (15-18 vs. 20-24), lateral series scales (31-35 vs. 37-42), and horizontal scale rows between dorsal-fin origin and anal-fin origin (11-13 vs. 13-16).

Description. Table 4 presents morphometrics of holotype and paratypes and specimens from near type locality. Table 5 presents morphometrics of specimens collected from riacho dos Pardos, branch of rio Canoinhas, tributary of rio Iguaçu, Paraná State. Except where noted, the description refers to population sample from near the type locality. In the statistical analyses of sexual dimorphism and in the statistical comparisons between G. melanopleura and G. caerulea all the collections of later were treated as one population sample.
Counts and ratios of measurements for population sample from riacho dos Pardos are discussed only when they differ from those from near the type locality.

Body compressed, relatively deep, especially anterior to dorsal-fin origin; body deepest at vertical through approximately pelvic-fin origin. Predorsal body profile relatively arched in adult males and adult females (Figs. 20 and 21). Immatures with profile somewhat more gently convex. Dorsal profile of body nearly straight and posteroventrally inclined; profile nearly horizontal and straight from dorsal-fin termination to origin of adipose fin. Body profile posterior to adipose fin very slightly concave dorsal to caudal peduncle, inclined slightly upward to origin of procurrent caudal-fin rays. Dorsal-fin origin nearer to caudal-fin base than to snout tip. Ventral profile of body strongly convex in adult males from tip of lower jaw to region near isthmus where it becomes nearly straight. Abdomen rounded to pelvic-fin origin, somewhat less strongly convex in females and immatures. Profile in adult males slightly concave from pelvic-fin origin to anal-fin origin, straight or nearly so in females. Anal-fin base in males slightly convex, less so in females and juveniles. Ventral profile of caudal peduncle nearly straight in adult males and females to origin of procurrent ventral caudal-fin rays.

Lower jaw equal to or slightly shorter than upper jaw. Lower jaw of adult males somewhat thicker and heavier relative to that of females and juveniles. Mouth angled posteroventrally. Maxilla long, extending to point ventral to horizontal along ventral border of eye. Maxilla extends posteriorly to point just anterior to vertical through center of pupil.

Table 4. Morphometrics of Glandulocauda caerulea. Standard length is expressed in mm; measurements through bony head length are percentages of standard length; the last four entries are percentages head length. A plus sign under the abbreviation dif. indicates there is a significant statistical difference between the males and females in the particular character indicated. Those receiving a plus sign and an asterisk are probably not significant. The type specimens, all from Serrinha Paraná, Brazil were described by Eigenmann as Glandulocauda melanopleura and include FMNH 54895 (holotype); FMNH 54896 (paratypes); USNM 177725 (paratype); CAS (IUM) 13273 (paratype). The following recently collected specimens are from near the type locality: MZUSP 53273 and USNM 326756. SD = Standard deviation.

\begin{tabular}{|c|c|c|c|c|c|c|c|c|c|c|}
\hline \multirow{2}{*}{ Characters } & \multicolumn{4}{|c|}{ Males } & \multicolumn{5}{|c|}{ Females and juveniles } & \multirow[b]{2}{*}{ dif. } \\
\hline & $\mathrm{N}$ & Range & Mean & SD & Holotype & $\mathrm{N}$ & Range & Mean & SD & \\
\hline Standard length & 06 & $37.6-43.9$ & 40.3 & & 38.5 & 10 & $22.4-40.4$ & 32.5 & & \\
\hline Depth at dorsal-fin origin & 06 & 31.9-36.9 & 33.9 & 2.3 & 29.1 & 10 & 28.1-32.6 & 29.8 & 0.1 & + \\
\hline Snout to dorsal-fin origin & 06 & $52.3-56.6$ & 54.8 & 1.6 & 57.7 & 10 & $54.0-61.3$ & 56.8 & 2.3 & - \\
\hline Snout to pectoral-fin origin & 06 & $25.0-27.4$ & 26.3 & 0.8 & 26.0 & 10 & $24.3-28.2$ & 25.5 & 1.0 & - \\
\hline Snout to pelvic-fin origin & 06 & $43.0-45.6$ & 44.0 & 0.1 & 44.9 & 10 & $42.1-46.8$ & 44.0 & 0.1 & - \\
\hline Snout to anal-fin origin & 06 & 57.3-61.9 & 60.2 & 1.7 & 61.6 & 10 & $56.5-64.8$ & 61.1 & 2.6 & - \\
\hline Caudal peduncle depth & 06 & $15.4-19.2$ & 17.6 & 1.3 & 14.9 & 10 & $14.0-16.0$ & 15.0 & 0.7 & + \\
\hline Caudal peduncle length & 06 & $17.2-19.2$ & 18.1 & 0.7 & 13.0 & 10 & $13.0-18.3$ & 16.0 & 1.6 & + \\
\hline Pectoral-fin length & 06 & $22.2-23.8$ & 22.8 & 0.6 & 18.4 & 09 & $16.6-22.0$ & 19.7 & 1.6 & + \\
\hline Pelvic-fin length & 06 & $19.1-21.3$ & 20.1 & 0.9 & 14.5 & 10 & $12.2-17.1$ & 15.0 & 1.6 & + \\
\hline Dorsal-fin base length & 06 & $13.3-15.5$ & 14.1 & 0.8 & 13.5 & 10 & 11.6-13.7 & 12.8 & 0.7 & + \\
\hline Dorsal-fin height & 06 & $26.2-30.2$ & 28.1 & 0.1 & 28.1 & 09 & $23.9-28.0$ & 25.4 & 1.4 & + \\
\hline Anal-fin base length & 06 & $24.4-28.0$ & 26.7 & 1.2 & 25.7 & 10 & 23.4-26.1 & 24.9 & 0.8 & - \\
\hline Anal-fin lobe length & 06 & $20.2-24.6$ & 21.3 & 1.6 & 20.8 & 10 & $18.7-22.1$ & 20.5 & 1.0 & - \\
\hline Eye to dorsal-fin origin & 06 & $40.9-46.2$ & 43.4 & 1.7 & 45.2 & 10 & $39.5-45.7$ & 42.6 & 0.1 & - \\
\hline Dorsal-fin origin to caudal-fin base & 06 & 48.3-51.5 & 50.1 & 1.2 & 47.8 & 10 & $46.1-50.7$ & 47.7 & 1.2 & - \\
\hline Bony head length & 06 & $26.2-27.9$ & 26.7 & 0.6 & 26.0 & 10 & 24.6-29.7 & 26.6 & 1.6 & - \\
\hline Horizontal eye diameter & 06 & $28.7-32.3$ & 30.5 & 1.5 & 30.0 & 10 & $30.0-35.1$ & 33.4 & 1.6 & - \\
\hline Snout length & 06 & $27.3-31.0$ & 29.6 & 1.5 & 24.0 & 09 & $19.3-30.5$ & 24.4 & 4.2 & - \\
\hline Least interorbital width & 06 & $36.4-41.2$ & 39.2 & 1.8 & 36.0 & 10 & $34.1-40.6$ & 32.9 & 1.1 & $+*$ \\
\hline Upper jaw length & 06 & 42.4-44.7 & 43.8 & 0.9 & 46.0 & 10 & $41.3-47.7$ & 44.4 & 2.1 & - \\
\hline
\end{tabular}


Table 5. Morphometrics of Glandulocauda caerulea. Standard length is expressed in mm; measurements through bony head length are percentages of standard length; the last four entries are percentages head length. A plus sign under the abbreviation dif indicates there is a significant statistical difference between the males and females in the particular character indicated. All specimens are from riacho dos Pardos, tributary of rio Canoinhas, Santa Catarina State, Brazil. MNRJ 5642. SD = Standard deviation.

\begin{tabular}{|c|c|c|c|c|c|c|c|c|c|}
\hline \multirow{2}{*}{ Characters } & \multicolumn{4}{|c|}{ Males } & \multicolumn{4}{|c|}{ Females and juveniles } & \multirow[b]{2}{*}{ dif. } \\
\hline & $\mathrm{N}$ & Range & Mean & SD & $\mathrm{N}$ & Range & Mean & SD & \\
\hline Standard length & 04 & $28.6-35.2$ & 32.0 & & 26 & $17.4-34.1$ & 24.5 & & \\
\hline Depth at dorsal-fin origin & 04 & $31.5-34.6$ & 33.5 & 1.3 & 26 & 26.1-33.9 & 30.1 & 0.1 & + \\
\hline Snout to dorsal-fin origin & 04 & $55.5-56.5$ & 56.0 & 0.4 & 26 & $55.0-61.1$ & 58.2 & 1.5 & - \\
\hline Snout to pectoral-fin origin & 04 & 24.6-25.9 & 25.4 & 0.6 & 26 & $24.0-29.5$ & 26.9 & 1.4 & - \\
\hline Snout to pelvic-fin origin & 04 & $42.9-46.3$ & 44.8 & 1.4 & 26 & $43.1-50.9$ & 46.2 & 1.4 & - \\
\hline Snout to anal-fin origin & 04 & $56.4-62.4$ & 60.3 & 2.8 & 26 & $59.7-64.9$ & 62.1 & 1.2 & - \\
\hline Caudal peduncle depth & 04 & $16.2-18.0$ & 16.9 & 0.8 & 26 & $13.0-16.2$ & 14.6 & 0.9 & + \\
\hline Caudal peduncle length & 04 & $14.0-16.6$ & 15.5 & 1.1 & 26 & $12.0-17.0$ & 14.1 & 1.3 & + \\
\hline Pectoral-fin length & 04 & $21.0-24.6$ & 22.5 & 1.5 & 24 & $19.4-22.8$ & 20.9 & 0.8 & + \\
\hline Pelvic-fin length & 04 & $20.1-22.5$ & 21.4 & 1.1 & 26 & $14.6-19.5$ & 16.8 & 1.9 & + \\
\hline Dorsal-fin base length & 04 & $14.3-15.9$ & 15.1 & 0.7 & 26 & $11.1-14.9$ & 13.1 & 0.1 & + \\
\hline Dorsal-fin height & 04 & $26.4-30.5$ & 28.4 & 1.7 & 26 & $22.6-28.5$ & 25.5 & 1.4 & + \\
\hline Anal-fin base length & 04 & $23.9-27.9$ & 26.4 & 1.8 & 26 & $21.8-27.7$ & 24.1 & 0.1 & - \\
\hline Anal-fin lobe length & 04 & $19.5-21.7$ & 20.4 & 1.0 & 22 & $16.6-22.6$ & 19.8 & 1.5 & - \\
\hline Eye to dorsal-fin origin & 04 & $41.2-44.1$ & 42.3 & 1.3 & 26 & $40.2-45.4$ & 43.4 & 1.3 & - \\
\hline Dorsal-fin origin to caudal-fin base & 04 & $48.5-52.8$ & 50.5 & 1.8 & 26 & $44.8-51.4$ & 47.6 & 1.6 & - \\
\hline Bony head length & 04 & $18.2-27.8$ & 27.6 & 2.3 & 26 & $25.8-31.0$ & 28.5 & 1.2 & - \\
\hline Horizontal eye diameter & 04 & $30.4-34.4$ & 33.1 & 1.8 & 26 & $30.3-40.0$ & 35.7 & 2.3 & - \\
\hline Snout length & 04 & $18.4-22.7$ & 21.2 & 1.9 & 26 & $15.6-21.6$ & 18.9 & 1.5 & - \\
\hline Least interorbital width & 04 & $34.4-38.5$ & 36.4 & 2.1 & 26 & $30.0-36.7$ & 33.3 & 1.7 & - \\
\hline Upper jaw length & 04 & $41.3-45.8$ & 44.1 & 0.2 & 26 & $38.8-46.2$ & 41.4 & 2.2 & - \\
\hline
\end{tabular}

Dorsal-fin rays ii, 8, (same in all specimens except one from MZUSP 53273 which had ii, 7), $\mathrm{n}=45$; posterior ray not split to its base and counted as 1 ray). Adipose fin, elongate and relatively slender (Figs. 20 and 21). Anal-fin unbranched rays iv, iii in one FMNH 54896, branched rays 15-18 (17), 16.9, $\mathrm{n}=41$; posterior ray split to its base and counted as 1 ray (Fig. 26). Male anal fin with moderately developed lobe anteriorly (Figs. 20, 21 and 26); lobe includes anterior undivided rays and first 4 or 5 divided rays. Anal fin of sexually mature males with bilateral hooks, 3-4 very small hooks on unbranched ray iii, up to 23 hooks on unbranched ray iv with usually one ray per segment on these rays (Fig. 26). Anterior 4-5 branched fin rays with bilateral hooks, approximately 18-20 hooks on one side for first branched ray, usually 1 hook per ray segment but sometimes 2 , some of hooks very small. Second and third branched rays with 15-18 hooks, similar to those of first branched ray, fourth to sixth branched rays with one or two hooks. Pectoral-fin unbranched ray i in all specimens, branched rays 10-12 (11), $11.1, \mathrm{n}=16$, specimens from type locality area; mean $=10.7,4$ range $10-12, n=24$, specimens from rio Canoinhas. Pectoral fin extends posteriorly to, or slightly beyond origin of pelvic fins in adult males but slightly short of that point in females. Pelvicfin rays 7, anterior ray branched (of 16 specimens collected near or at type locality, anterior first ray branched in 6 specimens with count equal to 7 for each and anterior ray unbranched in 10 specimens with count $=$ i, 6 for each specimen (see Fig. 27). Pelvic fin sometimes with anterior ray unbranched on one side and unbranched on other side. Medial branch sometimes divided. Branches not necessarily remaining close together. Sexually mature, large adult males with over 220 hooks on each pelvic fin many of them minute, distributed as shown in Fig. 27.

Principal caudal-fin ray count 10/9 in all specimens, $\mathrm{n}=$ 44. Principal caudal-fin rays 11-13 somewhat bowed ventrally in association with glandular tissue (Fig. 32). Scales cycloid, with approximately 1012 radii along posterior field of larger scales; fewer radii in smaller scales. Terminal scale of modified caudal-fin series without complex radii (Fig. 24).

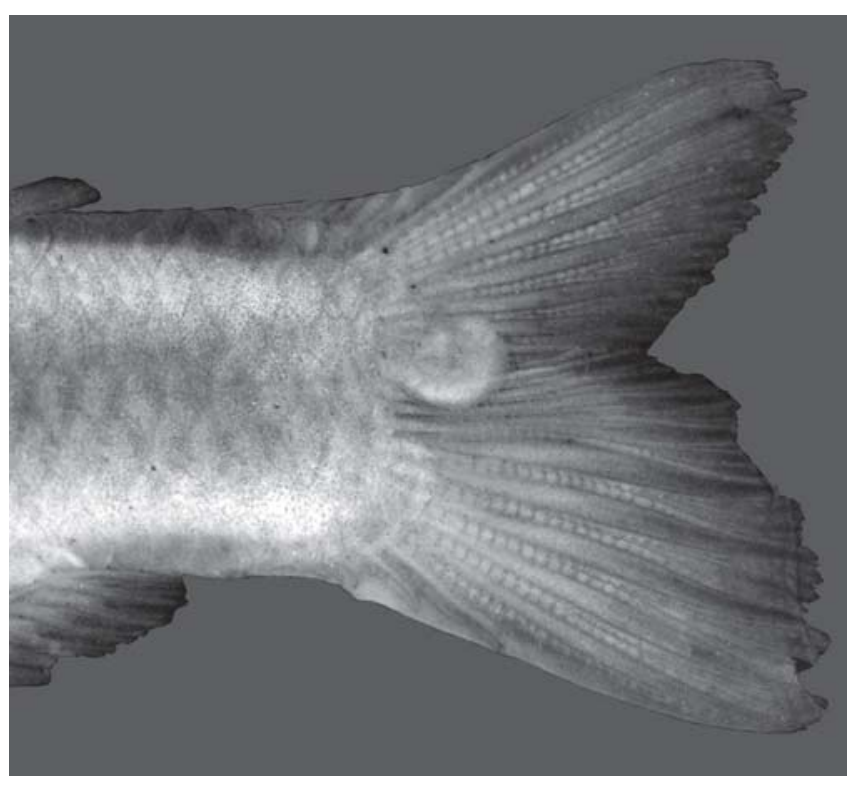

Fig. 22. Glandulocauda caerulea, adult male, USNM 326756, $43.9 \mathrm{~mm}$ SL; caudal fin and caudal peduncle. 


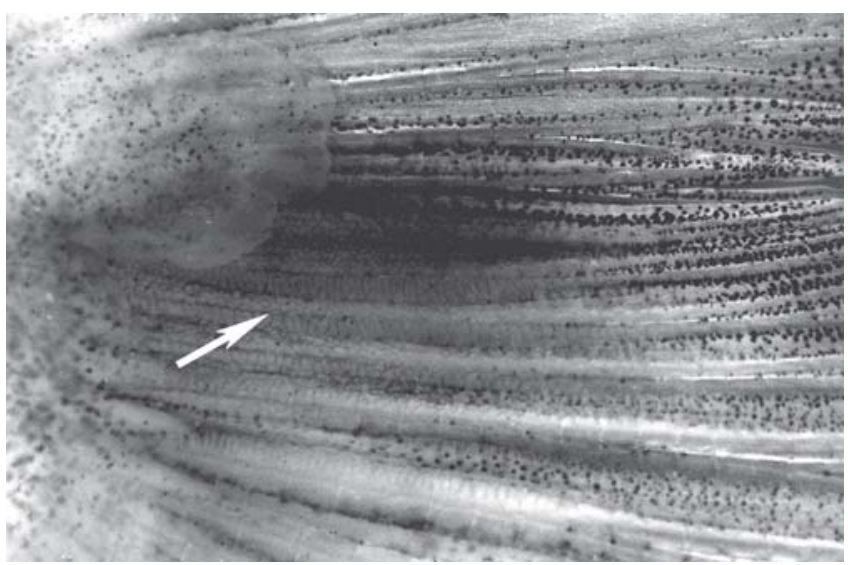

Fig. 23. Glandulocauda caerulea, adult male, USNM 326756, $43.9 \mathrm{~mm}$ SL; detail of caudal organ of adult male showing beaded glandular tissue indicated by arrow. Lateral view, left side.

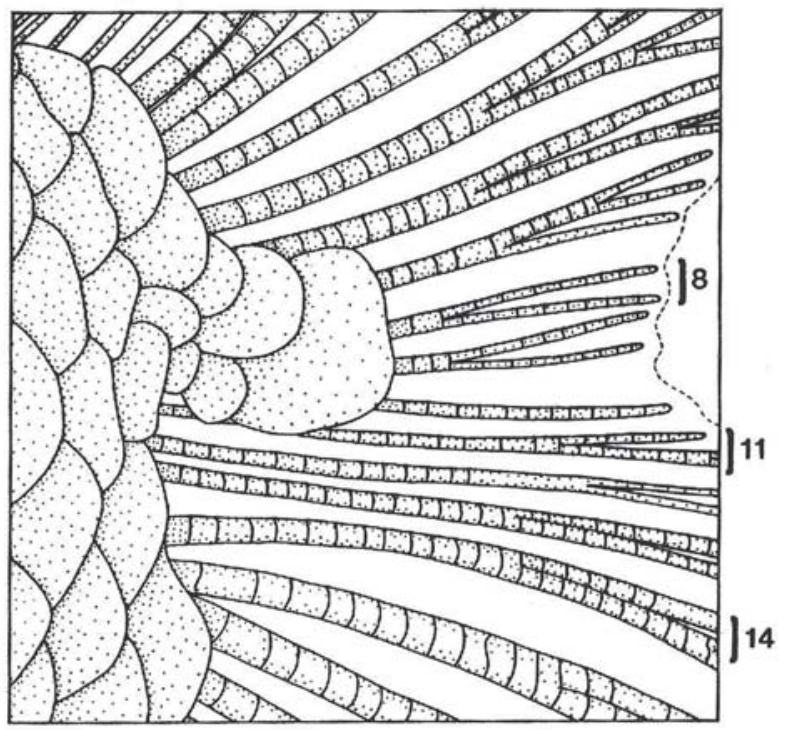

Fig. 24. Glandulocauda caerulea, adult male, USNM 326756, $39.4 \mathrm{~mm}$ SL; detail of caudal squamation in relation to principal caudal-fin rays 6-11. Lateral view, left side.

Lateral line incomplete, perforated scales 4-8 (6), 5.4, $\mathrm{n}=$ 16 , specimens from and near type locality; 4-6, 5.3, $n=29$, in specimens from rio Canoinhas, SC. Lateral series scales 31-35 (34), 33.6, $n=16$, specimens from and near type locality; 32$35,33.8, n=29$, in specimens from rio Canoinhas, SC. Predorsal scales 15-18 (16), 16.6, $\mathrm{n}=16$, specimens from and near type locality; $15-17,16.1, n=27$, in specimens from rio Canoinhas. Scale rows between dorsal-fin and anal-fin origins 12 (12 in all specimens from and near type locality; 11-13, 12, $\mathrm{n}=30$ in specimens from rio Canoinhas, SC. Scale rows around caudal peduncle 16 (16 in all specimens from all localities).

Premaxillary teeth in 2 distinct rows (Fig. 28). All teeth tricuspid to quinticuspid in large specimens, small teeth sometimes bicuspid or conical in smaller specimens. Outer row teeth 3-4 (3), n= 16 in specimens from or near type locality;
2-4, 3.0, $\mathrm{n}=26$ in specimens from rio Canoinhas, SC. Inner row teeth few, 4-5 (4), 4.3, $\mathrm{n}=16$ in specimens from or near type locality; 4-5, 4.2, $\mathrm{n}=26$ in specimens from rio Canoinhas, SC. Maxillary teeth 2-4 (3), 2.5, $\mathrm{n}=16$ in specimens from or near type locality; 2-3, 2.4, $\mathrm{n}=26$ in specimens from rio Canoinhas, SC, larger specimens usually with higher counts. Anterior maxillary teeth (Fig. 28) usually tricuspid, posterior teeth bicuspid or tricuspid in large specimens, often conical in small specimens. Dentary with 4-5 (4) large tricuspid or bicuspid anterior teeth, 4.1, $\mathrm{n}=16$ in specimens from or near type locality; 3-4, 3.96, $n=26$ in specimens from rio Canoinhas, SC. Smaller posterior teeth 4-8 (7), 6.3, $\mathrm{n}=16$ in specimens from or near type locality; 4-7, 5.4, $\mathrm{n}=26$ in specimens from rio Canoinhas, SC. Number of teeth almost always greater in largest specimens. Anterior small teeth of posterior portion of dentary row bi- or tricuspid, with posterior one or two teeth conical (Fig. 28). Maxillary and dentary teeth shaped much like premaxillary teeth described above

Vertebrae 34-36 (36), 35.3, $\mathrm{n}=19$ in specimens from or near type locality; 34-36, 35.5, $\mathrm{n}=60$ in specimens from rio Canoinhas. Dorsal limb gill rakers 6-7 (7), 6.4, $\mathrm{n}=16$ in specimens from or near type locality; 6-7, 6.2, $\mathrm{n}=30$ in specimens from rio Canoinhas. Ventral limb gill rakers 9-10 (10), 9.5, $\mathrm{n}=16$ in specimens from or near type locality; 8-10, 9.2, $\mathrm{n}=30$ in specimens from rio Canoinhas. Branchiostegal rays 4 in 2 cleared and stained specimens; 3 rays originating on anterior ceratohyal and 1 ray from posterior ceratohyal.

Color in alcohol. See Figs. 20 and 21 for preserved color pattern of males and females. Body gray brown to pale yellowish brown ventrally, darker dorsally. Lateral body stripe broad and reasonably well-defined anteriorly and posteriorly in both sexes. Stripe extends from elongate vertically-aligned humeral spot that lies immediately posterior to opercle and cleithrum to caudal-fin base. Continues diffusely onto both caudal-fin lobes (especially fin rays of those lobes) in males and as a wedge shaped mark onto middle caudal-fin rays in some females. Stripe somewhat darker on principal caudal-fin rays 10, 11 and 12. Remainder of caudal fin dusky. Dorsal border of first principal caudal-fin ray and ventral border of nineteenth principal caudal-fin ray black. Midddorsal dorsal body surface nearly black and forming a narrow stripe extending from supraoccipital region to base of dorsal procurrent rays of caudal fin. Remainder of dorsal body surface dorsal to lateral body stripe pale brown, darker dorsally.

Pectoral, pelvic, dorsal, and anal fins dusky with scattered dark chromatophores along fin rays and membranes. Anal fin with diffuse dark elongate stripe running length of its distal border and another, more distinct stripe along base of fin. In sexually mature males basal stripe about equal in intensity throughout and approximately covers basal one -half of fin. This stripe appears paler than distal half of fin in Fig. 20 because is more translucent distal and black in background .Dorsalfin with distally located horizontal dark stripe in adult males extending posteriorly from about mid-length of anterior elongate undivided ray to posterior tips of two terminal fin 


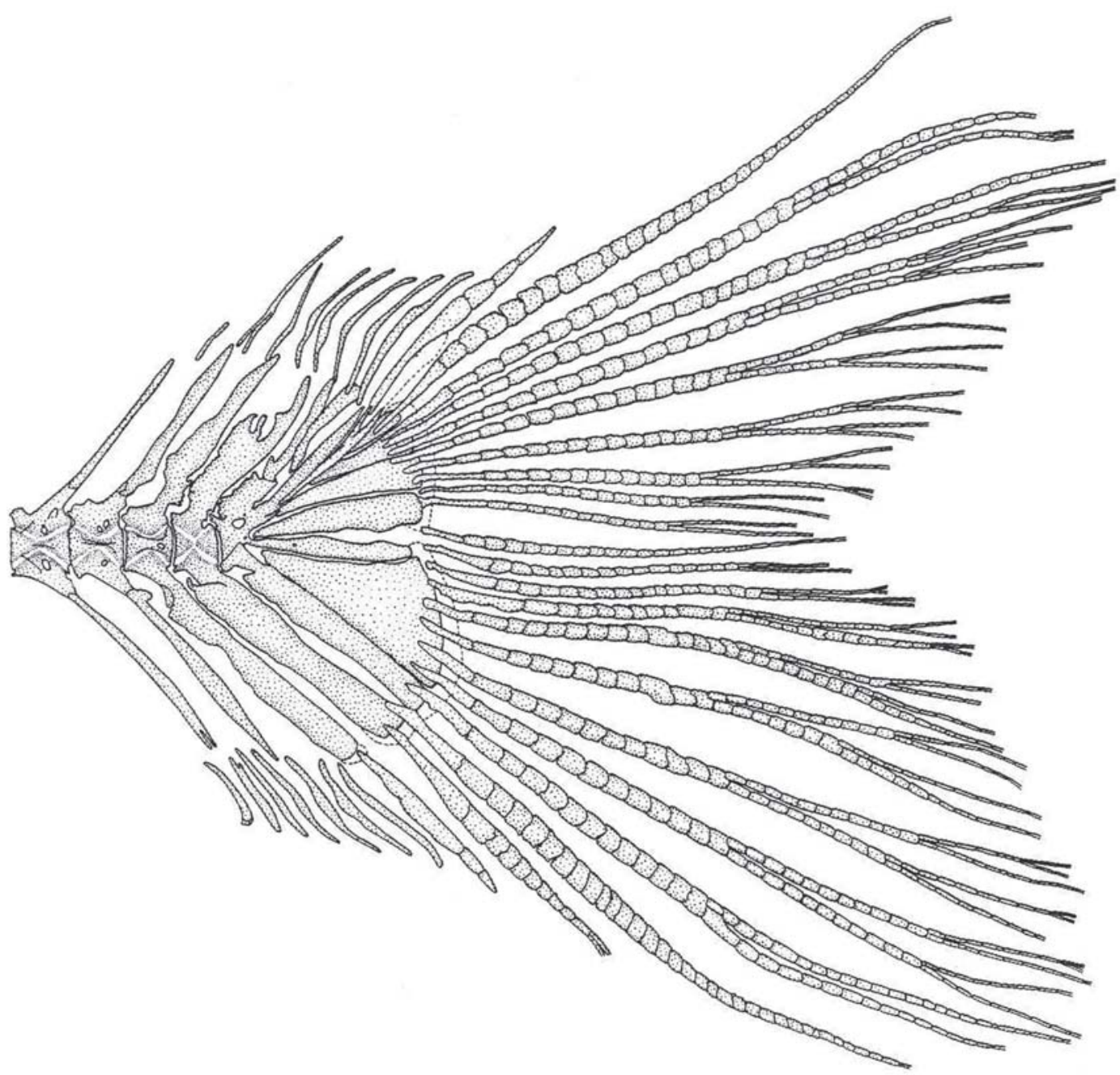

Fig. 25. Glandulocauda caerulea, adult male, USNM 326756, $39.4 \mathrm{~mm}$ SL; caudal skeleton and fin rays. Cartilage outlined by dashed lines. Lateral view, left side.

rays. This stripe relatively broad and diffuse, somewhat more than one-eighth maximum height of dorsal fin. Female with dusky dorsal fin, typically lacking dark stripe. Males sometimes with posterior portion of stripe diffuse. Adipose fin dusky with scattered dark chromatophores.

Head brown around mouth and on dorsal surface of snout, between eyes, dorsum of cranium and nape. Tip of lower jaw brown but pigment not organized into dark band. Head posterior to infraorbitals and extending ventrally from parietal region across dorsal opercular region dark brown. Opercular membrane translucent (opaque white in preservative). Iris dorsal to pupil dark brown, most of remainder of iris silvery. Infraorbitals silvery if guanine preserved, pale yellowish brown if guanine absent. Dark brown chromatophores scattered evenly through infraorbital area. Anterior area to opercle, all of preopercle, and branchiostegal rays silvery or pale brown if guanine is absent.

Color in life. Life colors described here taken from color slide of an adult male $41.8 \mathrm{~mm}$ SL (MZUSP 40281) that had been preserved for a short time. The site of capture was near type locality. Sides of body lead or gun metal blue, especially lateral stripe darker than rest of body. Immediately dorsal to blue color of body back with narrow lighter diffuse stripe more brown than blue. Line extends from parietal region ventral to adipose fin to caudal peduncle. Dorsomedian narrow dark brown of dorsal most portion of back lies immediately dorsal to brownish diffuse stripe. Dorsal region of caudal peduncle with same color as narrow dark line of back. Ventral portion of abdomen, most of lower jaw, ventral opercular area, branchiostegal rays and their membranes silvery bluishwhite to gray-bluish-white. Dark pigment of head similar to that in preserved specimens except that dorsal region of opercle appears silvery blue, almost a silvery sky blue. Principal caudal-fin rays 8-9 pale yellow basally, but with some dark pigment distally. Ray 10 and those below it with more of dark pigment approaching base of fin rays. Glandular tissue confined to rays 10-14 with limited dark pigment. Remainder of black pigment of caudal fin as described in preserved specimens. Anal fin reddish-gray distally. Basal 


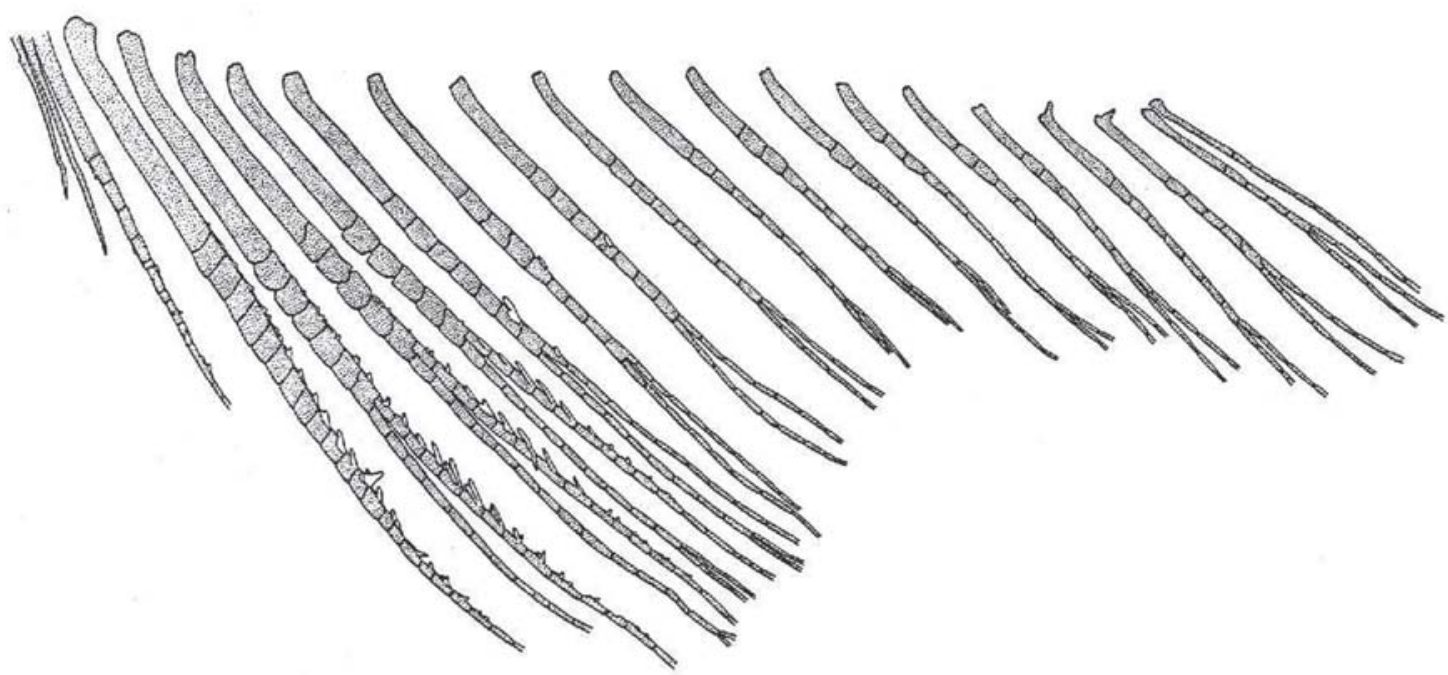

Fig. 26. Glandulocauda caerulea, adult male, USNM 326756, $39.4 \mathrm{~mm}$ SL; anal-fin rays, lateral view, left side. Lateral view, left side.

one-half of anal fin reddish brown or reddish gray in both sexes with scattered brown and red chromatophores. Approximately distal one-half to three-fourths of pelvic fins translucent blue in both sexes. Pectoral fins yellow translucent. Dorsal more or less hyaline with rays darker gray than membranes.

Sexual dimorphism. Females of Glandulocauda caerulea lack glandular caudal tissue found in sexually active males. Females have modified dorsal caudal squamation found in males but modification is much smaller than in males (compare Figs. 20 and 21). Females lack anal- and pelvic-fin hooks found in males (Fig. 27).

Live color pattern differences of photographed males and females in breeding condition from near type locality are very similar. The greatest difference is in fin coloration which is more intense in males.

Tables 4 and 5 indicate that body depth, caudal peduncle depth, pectoral-fin length, pelvic-fin length, dorsal-fin base length and dorsal-fin height are greater in males than females. Statistical analyses of these data were not carried out because samples are limited to a few large males rendering comparisons meaningless.

Distribution. Examined specimens of Glandulocauda caerulea originated in streams of the upper rio Iguaçu in Paraná and Santa Catarina States, Brazil. See fig. 3 in Menezes et al. (2008) as Glandulocauda melanopleura.

Ecology. The creek where G. caerulea was collected is a fastflowing clear water stream about 15-20 cm deep and about a meter wide. The bottom was a mixture of sand, mud, and rocks with logs and other natural debris common. Araucaria brasiliensis and a species of Podacarpus were the prominent tree components in the surrounding riparian habitat with relatively small shrub species also common.

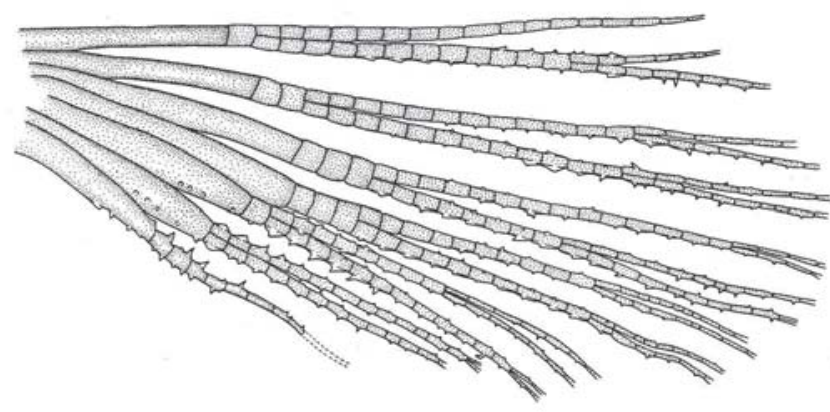

Fig. 27. Glandulocauda caerulea, adult male, USNM 326756 , 39.4 mm SL; pelvic-fin rays, ventral view, left side.

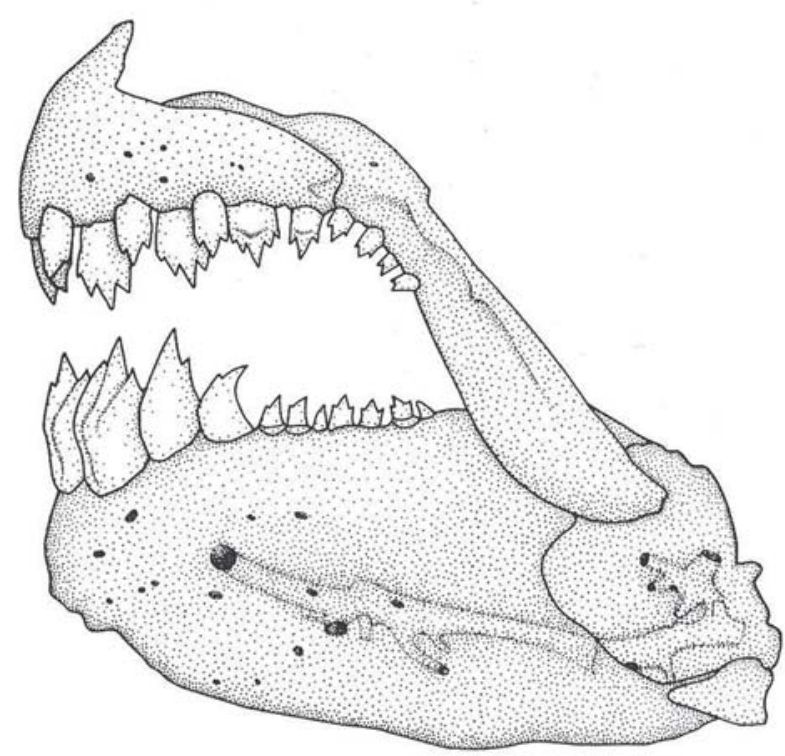

Fig. 28. Glandulocauda caerulea, adult male, USNM 326756, $39.4 \mathrm{~mm}$ SL; jaws and dentition, lateral view, right side, anterior at right. 
More recently, Ingenito et al. (2004) collected many specimens of $G$. melanopleura ( $=$ G. caerulea) in small very cold, clear water small creeks running into tributaries of rio Iguaçu. These were about $1.5 \mathrm{~m}$ wide and 0.3-1 m deep with marginal vegetation abundant.

Remarks. Glandulocauda caerulea and G. melanopleura can be distinguished by a variety of characters in addition to those utilized in the diagnosis. The color patterns are quite different with males of $G$. melanopleura predominantly yellowish brown while those of $G$. caerulea are predominantly blue.

Glandulocauda caerulea (then named as $G$. melanopleura) was reported by Menezes \& Weitzman (1990: 384 ) to have 4-6 perforated lateral line scales and $G$. melanopleura (then named as G. melanogenys) to have 11-21 but additional material indicates the numbers are 4-8 and 7-27 respectively. A significant difference remains, in spite of a slight overlap.

Eigenmann (1911b: 168-170) first described three species in Glandulocauda: G. inequalis, G. melanogenys (the type species of the genus), and G. melanopleura. Unfortunately, Glandulocauda melanogenys is a junior synonym of Hyphessobrycon melanopleurus Ellis (1911: 157-158), a situation not previously recognized. Thus, the species name melanogenys Eigenmann must be replaced by melanopleura Ellis. This makes G. melanopleura Eigenmann, proposed for a different species of Glandulocauda, a junior secondary homonym of G. melanopleura (Ellis) because both species are here kept in the same genus, Glandulocauda. A new replacement name, Glandulocauda caerulea Menezes \& Weitzman, is here proposed for G. melanopleura Eigenmann.

Notes on type locality. The type locality of G. melanopleura (= G. caerulea) was initially difficult to locate. Two localities bearing the name Serrinha, the type locality of $G$. melanopleura $(=G$. caerulea) existed in the region of Paraná southwest of Curitiba. The Serrinha where Haseman collected in 1908, was a railroad junction at approximately $25^{\circ} 43^{\prime} \mathrm{S} 49^{\circ} 44^{\prime} \mathrm{W}$ on the American Geographical Society Map of Hispanic America, section "SG-22, Curityba”, provisional edition for 1937. This locality is still called Serrinha on some fairly recent maps (e.g., Mapa do Estado do São Paulo, Rodoviário e Político for 1979, Geomapas Produções Cartográficas Ltda., São Paulo), but it does not appear on most current maps. The Rede Ferroviária Federal S. A. relocated the railroad in this area and station Serrinha was abandoned. The inhabitants of Balsa Nova, PR, suggested that the station might still be found on a ranch called Lara Maria, where an old railroad station was found with a nearby stream, called the ribeirão Amola Faca, draining to the rio Iguaçu. This stream produced a variety of fishes, but no specimens of Glandulocauda caerulea. That species was however collected from an adjacent creek flowing into the ribeirão Amola Faca. Although it is uncertain wheter this creek was the type locality, it is probably very close to the locality where Haseman collected.
Material examined. Holotype of Glandulocauda melanopleura. FMNH 54895, adult, 39.5 mm SL, Brazil, Paraná, Serrinha, rio Iguaçu, approximately 2543'S 4944'W, 22 Dec 1908, J. D. Haseman; see notes on type locality. Note: Weitzman \& Fink (1985: 104) reported specimen as male. Although it has well-developed modified dorsal lobe caudal-fin squamation, mature eggs were revealed when a small slit was made on the right side of its abdomen. Paratypes of G. melanopleura. Collected with holotype: FMNH 54896, 2 immature, 26.5-29.2 mm SL, (Note: These specimens identified as developing males by Weitzman \& Fink, 1985: 104). Both have well-developed modified caudal squamation but no evidence of glandular tissue. It is impossible to determine their sex without histological section); USNM 177725, 1 maturing female, $29.4 \mathrm{~mm}$ SL, (Note: This specimen, identified as a male by Weitzman \& Fink (1985: 104) because of its welldeveloped caudal squamation, but slit in right side of abdominal cavity revealed what looks to be a maturing ovary). Non-types. All collected in Brazil. MZUSP 53273, 1 juvenile, 22.4 mm SL, 3 males and 1 female, adults, 37.6-42.8 mm SL, Paraná, brook tributary to rio Iguaçu, near fazenda Lara Maria, near road; USNM 326756 3, adult males and females, 37.3-43.9 mm SL, 1, cleared and stained, adult male $39.4 \mathrm{~mm} \mathrm{SL}$, same locality as MZUSP 53273; MNRJ 5642, 30, 22 juveniles, 17.4-27.1 mm SL, 8 adult males and females, 28.5-35.2 mm SL, Santa Catarina, riacho dos Pardos, tributary to rio Canoinhas, tributary to rio Iguaçu, 5 Sept 1949, A. L. Carvalho.

\section{Mimagoniates Regan, 1907}

Mimagoniates Regan, 1907: 402 [type species: Mimagoniates barberi Regan (1907: 402) by monotypy].

Coelurichthys Miranda-Ribeiro, 1908: unpaginated; type species: Coelurichthys iporangae Miranda-Ribeiro, 1908: unpaginated (by monotypy).

Coalurichthys Miranda-Ribeiro, 1908: unpaginated; misspelling for Coelurichthys.

Diagnosis. All glandulocaudine species belonging to Mimagoniates have either a rudimentary or a fully developed caudal fin-ray pump (Figs. 32, 38, 47, 58, 67, 75, and 85) not present in the other two genera, in which principal caudal-fin rays 11 and 12 are not modified (Lophiobrycon, fig. 4 in Castro et al., 2003) or just decurved but not forming a pump (Glandulocauda, Figs. 15 and 25). Additionally Mimagoniates can be distinguished from these two genera by having the dorsal-fin origin posterior to vertical through anal-fin origin (Figs. 31, 36, 45, 53, 63, 70, and 78). In Lophiobrycon (Figs. 3 and 4) the dorsal-fin origin is anterior to vertical through analfin origin and closer to snout tip than to caudal-fin base and in Glandulocauda (Figs. 11-12 and 20-21) the dorsal-fin origin is slightly ahead of vertical through anal-fin origin. Also, in Mimagoniates adult males have no more than 1 hook on analfin rays that bear hooks, although sometimes 2 hooks might be present on anterior most branched ray and 3 on longest unbranched anterior ray (Figs. 33, 39, 50, 56, 65, 73, and 81) whereas in Glandulocauda species more than one hook are present on anal-fin rays that bear hooks (Figs. 16 and 26). 


\section{Mimagoniates inequalis (Eigenmann, 1911)}

Figs. 29-30

Glandulocauda inequalis Eigenmann, 1911b: 169, plate 5, fig. 5, (type locality: "Porto Alegre, Jan. 19, 1909”). - Eigenmann, 1914a: 42 (listed). - Henn, 1928: 68 (listed in type catalog). Eigenmann \& Myers, 1929: 489 (redescription based on type specimens). - Innes, 1935: 122 (aquarium description). - Holly, Meinken \& Rachow, 1950: 816 (aquarium description; citation of much aquarium and ichthyological literature previous to 1942). - Fowler, 1951: 413 (listed). - Böhlke, 1958: 43 (listed). - Nelson, 1964a: 62, 68, 120, 127 (systematics; morphology; courtship behavior). - Nelson, 1964b: 129 (courtship behavior). - Nelson, 1964c: 527-533 (courtship behavior). Géry, 1964: 8 (noted differences between $M$. inequalis and M. microlepis). - Géry, 1966: 229 (in key to males of Glandulocauda and Mimagoniates; unsure of proper generic allocation of $G$. inequalis). - Géry, 1977: 362 (listed in a brief discussion of Glandulocauda and Mimagoniates; unsure of generic allocation of $G$. inequalis). - Sterba, 1987: 68 (aquarium description). - Ibarra \& Stewart, 1987: 39 (listed in type catalog).

Mimagoniates inequalis Rachow, 1928: 16 (aquarium description). - Schultz, 1959: 11 (key, in part; only specimens from Porto Alegre; listed $M$. lateralis as a synonym; of specimens listed, $M$. inequalis USNM 94117 are $M$. lateralis and USNM 177704 includes 1 spm of $M$. microlepis; only USNM 94310 are all $M$. inequalis). Weitzman \& Fink, 1985: 106, 109 (listed in materials examined with evidence for placement of in Mimagoniates). Weitzman et al., 1988: 404-419 (discussion of relationships and biogeography). - Malabarba, 1989: 136 (listed in discussion). - Menezes \& Weitzman, 1990: 384 (in key to Glandulocaudini). - Weitzman \& Menezes, 1994: 3 (general discussion in non-systematic literature). - Weitzman et al., 1996: 200, 205, 209 (courtship behavior; reproduction;

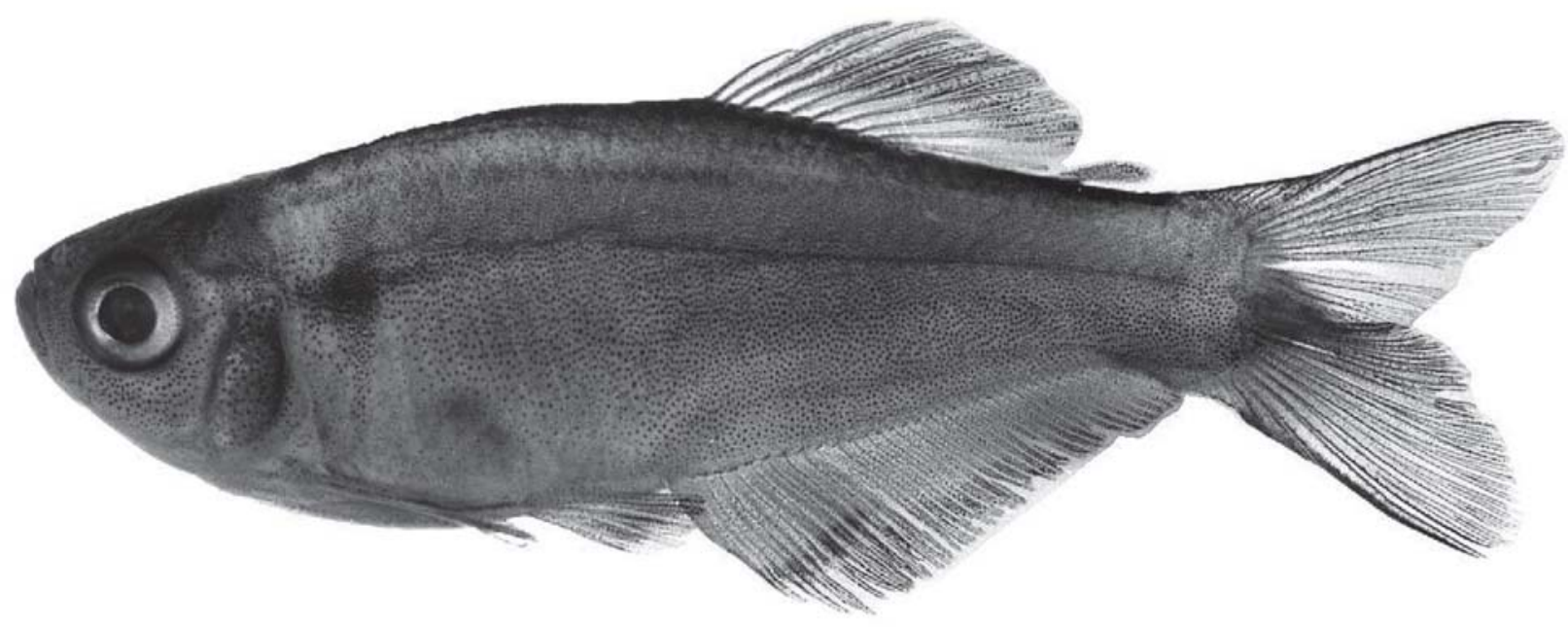

Fig. 29. Mimagoniates inequalis, male, UFRGS 3946, 27.5 mm SL, Brazil, Rio Grande do Sul, lagoa Emboaba, Tramandaí.

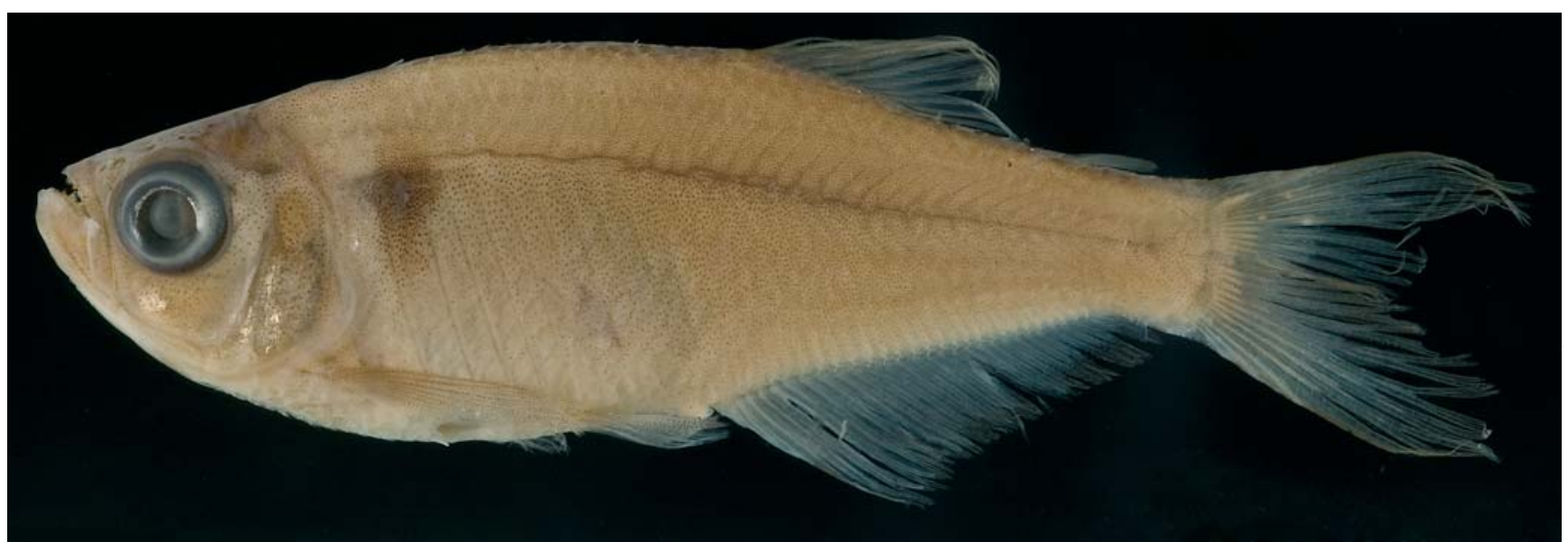

Fig. 30. Mimagoniates inequalis, female, MAPA 811, 22.7 mm SL, Brazil, Rio Grande do Sul, tributary to rio Gravataí at Morungava. 
breeding). - Weitzman, in Reis et al., 2003: 226 (maximum length; distribution; remarks; and references). - Menezes, in Buckup et al., 2007: 39 (listed in catalog; distribution). Menezes et al., 2008: 38-41 (distribution; discussion of relationships and biogeography).

Diagnosis. Based on the development of the caudal-fin ray pump, $M$. inequalis seems to be more similar to $M$. barberi and M. pulcher than to the other species of Mimagoniates but has fewer branched anal-fin rays (26 to 30) and vertebrae (36 to 39) than $M$. barberi (31 to 36 branched anal-fin rays and 41 to 46 vertebrae). From $M$. pulcher it differs by the number of lateral series scales (34 to 41 vs. 43 to 46 ) and horizontal scale rows from dorsal-fin origin to anal-fin origin (15 to 18 vs. 13 to 15 ).

The most striking color difference between $M$. inequalis and $M$. barberi is the presence in $M$. barberi of a prominent longitudinal black stripe extending from vertical posterior border of eye posteriorly to caudal fin base and in males onto portion of caudal fin occupied by caudal organ. The humeral dark spot is barely distinguishable from horizontal black stripe. In $M$. inequalis the lateral body shape is diffuse in both sexes and consists of scattered dark chromatophores extending from black vertical humeral spot posteriorly onto caudal fin.

Description. Table 6 presents morphometric data of the holotype and paratypes plus samples from within $70 \mathrm{~km}$ of Porto Alegre Rio Grande do Sul, Brazil and from Rivera, Uruguay. Many of the specimens in the description below are immatures to small adults. Therefore the means and other data given for these samples do not accurately reflect population samples with large numbers of adults.

Body compressed, relatively deep, especially near pelvicfin origin; body deepest at vertical through pelvic-fin origin or just anterior to that position. Predorsal body profile somewhat arched in all specimens which have predorsal profile gently convex to dorsal of eyes. Body profile slightly elevated at dorsal-fin origin. Dorsal body profile nearly straight along dorsal-fin base and then to adipose fin. Body profile posterior to adipose fin somewhat concave dorsal to caudal peduncle. Dorsal-fin origin nearer to caudal-fin base than to snout tip. Ventral profile of body strongly convex in adult males and females from tip of lower jaw to origin of pelvic fin, less strongly convex in immatures. Abdominal profile straight to slightly concave between pelvic-fin base and to anal-fin origin in all specimens. Body profile along anal-fin base in males straight to slightly concave, somewhat concave in females and immatures. Ventral profile of caudal peduncle initially straight but very short in adult males, then slopes downward along strongly developed ventral procurrent caudalfin rays. Region nearly straight in females and immatures including procurrent ventral caudal-fin rays. Snout blunt. Lower jaw protruding slightly anterior to upper jaw. Lower jaw of adult males somewhat thick and heavy compared to that of females and immatures. Mouth angled posteroventrally. Maxilla long, extending to point horizontal along ventral border of eye in all specimens. Maxilla extending posteriorly to approximately

Table 6. Morphometrics of Mimagoniates inequalis (Eigenmann). Standard length is expressed in mm; measurements through bony head length are percentages of standard length; the last four entries are percentages of head length. A plus sign under the abbreviation dif indicates there is a significant statistical difference between the males and females in the particular character indicated. Specimens are from within approximately $70 \mathrm{~km}$ of Porto Alegre from the north side of the rio Jacuí and laguna dos Patos, Rio Grande do Sul, Brasil, FMNH 54893 (holotype of Glandulocauda inequalis Eigenmann), FMNH 54894, CAS (IUM) 13270 (paratypes of G. inequalis), MAPA 811, MZUSP 26908, MZUSP 83355, USNM 254273, USNM 254274 and from Rivera, Uruguay, USNM uncatalogued. SD = Standard deviation.

\begin{tabular}{|c|c|c|c|c|c|c|c|c|c|c|}
\hline \multirow{2}{*}{ Characters } & \multicolumn{5}{|c|}{ Males } & \multicolumn{4}{|c|}{ Females and juveniles } & \multirow[b]{2}{*}{ dif. } \\
\hline & Holotype & $\mathrm{N}$ & Range & Mean & SD & $\mathrm{N}$ & Range & Mean & SD & \\
\hline Standard length & 33.3 & 66 & $16.3-38.3$ & 24.2 & & 75 & $14.5-29.8$ & 19.8 & & \\
\hline Depth at dorsal-fin origin & 33.6 & 66 & $27.0-34.0$ & 30.8 & 1.9 & 75 & $26.0-32.8$ & 28.9 & 1.9 & - \\
\hline Snout to dorsal-fin origin & 56.2 & 66 & 56.1-61.6 & 59.0 & 1.4 & 75 & $56.0-63.0$ & 59.2 & 1.5 & - \\
\hline Snout to pectoral-fin origin & 27.6 & 66 & $25.1-30.0$ & 27.2 & 0.9 & 75 & $24.8-30.3$ & 27.4 & 1.1 & - \\
\hline Snout to pelvic-fin origin & 46.2 & 66 & $42.0-47.0$ & 44.3 & 1.2 & 75 & $42.7-48.8$ & 45.0 & 1.2 & - \\
\hline Snout to anal-fin origin & 59.2 & 66 & $53.4-59.5$ & 56.6 & 1.4 & 75 & $54.2-60.8$ & 57.1 & 1.4 & - \\
\hline Caudal peduncle depth & 15.3 & 66 & $10.7-16.6$ & 13.6 & 1.4 & 75 & $09.2-14.7$ & 11.7 & 1.5 & + \\
\hline Caudal peduncle length & 09.3 & 66 & $08.0-11.2$ & 09.6 & 0.8 & 75 & $07.5-11.7$ & 09.1 & 0.8 & - \\
\hline Pectoral-fin length & 23.4 & 65 & $20.6-26.0$ & 23.7 & 1.0 & 75 & $20.0-25.7$ & 23.4 & 1.2 & - \\
\hline Pelvic-fin length & 17.4 & 66 & $12.7-17.5$ & 14.6 & 1.2 & 75 & $10.8-15.5$ & 13.1 & 0.8 & + \\
\hline Dorsal-fin base length & 16.5 & 66 & $13.0-17.8$ & 15.0 & 1.1 & 75 & $12.3-17.6$ & 14.6 & 1.1 & - \\
\hline Dorsal-fin height & 28.8 & 64 & $20.1-28.8$ & 24.2 & 2.0 & 66 & $20.2-26.7$ & 23.1 & 1.7 & - \\
\hline Anal-fin base length & 36.6 & 66 & $34.4-40.6$ & 37.2 & 1.4 & 75 & $34.0-40.4$ & 36.7 & 1.4 & - \\
\hline Anal-fin lobe length & 22.2 & 63 & $18.2-23.6$ & 20.8 & 1.2 & 75 & $16.6-25.6$ & 20.5 & 1.8 & - \\
\hline Eye to dorsal-fin origin & 46.2 & 66 & $44.3-48.5$ & 46.3 & 1.1 & 75 & 42.7-49.0 & 45.8 & 1.5 & - \\
\hline Dorsal-fin origin to caudal-fin base & 45.0 & 66 & $41.2-47.4$ & 44.1 & 1.6 & 75 & $40.6-45.5$ & 43.1 & 1.2 & - \\
\hline Bony head length & 27.6 & 66 & $25.3-29.8$ & 27.5 & 1.0 & 75 & $26.8-30.2$ & 27.9 & 1.0 & - \\
\hline Horizontal eye diameter & 33.3 & 66 & $33.3-40.6$ & 37.0 & 1.9 & 75 & $33.7-44.0$ & 38.4 & 1.8 & - \\
\hline Snout length & 22.2 & 66 & $18.6-25.0$ & 22.0 & 1.5 & 75 & $19.1-24.2$ & 21.6 & 1.5 & - \\
\hline Least interorbital width & 35.6 & 66 & 32.1-39.7 & 35.8 & 1.8 & 75 & 30.6-39.5 & 35.5 & 2.1 & - \\
\hline Upper jaw length & 44.4 & 66 & $38.6-47.5$ & 43.2 & 1.8 & 75 & $38.0-46.7$ & 42.6 & 1.7 & - \\
\hline
\end{tabular}


vertical through anterior border of eye.

Dorsal-fin unbranched rays ii in all specimens, branched rays 8-9 (8), 8.2, $\mathrm{n}=127$; posterior ray not split to its base and counted as 1 ray. Adipose fin elongate and slender. Principal caudal-fin ray count $10 / 9$ in all specimens, $n=127$. Fin rays modified in association with caudal pheromone pump as in Fig. 32. Fin rays modified more like those in $M$. barberi and $M$. pulcher than other species of Mimagoniates (compare Figs. 32, 38 and 47). Anal-fin unbranched rays iv or rarely v, branched rays 23-30 (28), 26.8, $n=127$; posterior ray split to its base and counted as 1 ray. Anal fin barely showing anterior lobe (Figs. 29, 30 and 33).

Anal fin of sexually mature males with bilateral hooks, 1 on each side, on last unbranched ray (Fig. 33). Usually anterior 6 branched fin rays with bilateral hooks, 1 set of hooks for each ray; occasionally 2 hooks per ray on a side but always only 1 hook per segment on a side. Pectoral-fin unbranched ray $\mathrm{i}$ in all specimens, branched rays 9-11 (9), 9.8, $\mathrm{n}=127$. Tip of pectoral fin extends beyond pelvic-fin origin. Pelvic fin rays i, 6 (branching of anterior, first ray variable in our population samples, i, 6 in 63 specimens, most under approximately $20 \mathrm{~mm} \mathrm{SL}$, but 7 in 64 specimens, most of them over approximately $20 \mathrm{~mm} \mathrm{SL}$ ), $\mathrm{n}=127$. Fig. 34 illustrates anterior branched pelvic ray. Total pelvic-fin rays 7 in all specimens examined, $n=127$. Sexually mature, large adult males with over 260 minute to small sized hooks on each pelvic fin distributed as shown in Fig. 34.

Scales cycloid, with few radii along posterior border. Terminal scale of modified caudal-fin series without exaggerated radii (Fig. 32). Lateral line incomplete, perforated scales 5-8 (6), $n=79$. Lateral series scales 34-41 (39), 38.2, $n=$

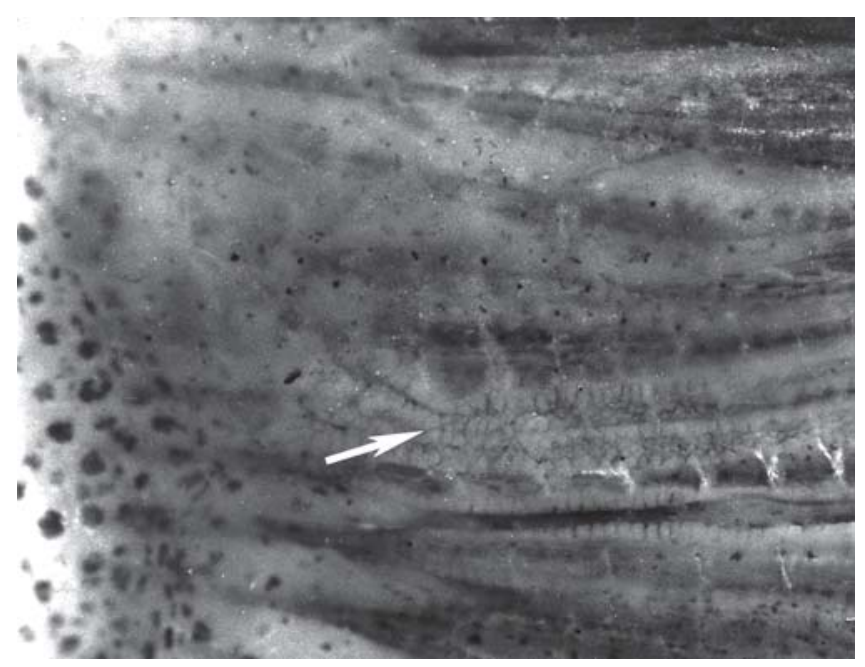

Fig. 31. Mimagoniates inequalis, male, MZUSP 75515, 33.1 $\mathrm{mm}$ SL; central region of caudal-fin base and fin showing beaded tissue indicated by arrow along borders of principal caudal-fin rays 11-14. Upper cluster of beaded tissue primarily positioned along borders of rays 11 and 12, rays that border groove of primitive caudal pump.
79. Predorsal scales 18-22 (18), 19.3, $\mathrm{n}=8$. Scale rows between dorsal-fin and anal-fin origins 15-18 (16), 16.0, $\mathrm{n}=108$. Scale rows around caudal peduncle 15-19 (16), 17.3, $\mathrm{n}=59$.

Premaxillary teeth tricuspid in all large specimens (Fig. 35), smaller teeth sometimes bicuspid or conical in smaller specimens. Premaxillary teeth 6-9 (8), 7-9, $\mathrm{n}=127$ in a single row, usually tricuspid, occasionally one or two bicuspid or conical at posterior portion. Maxillary teeth (Fig. 35) 3-10 (4), 4-6, larger specimens usually with higher counts, $n=127$. Dentary with 4 large anterior tricuspid teeth, followed by smaller posterior teeth 4-12 (6), 6.1, anterior small dentary teeth of posterior row tricuspid, posterior ones conic, $\mathrm{n}=124$ (Fig. 35). Smaller individuals tend to have fewer teeth than larger specimens. Maxillary and dentary teeth shaped much like premaxillary teeth. No significant difference in tooth number between sexes.

Vertebrae 36-39 (38), 37.9, $n=49$. Dorsal limb gill rakers 57 (6), 6.3, n = 127; ventral limb gill rakers 10-12 (11), 10.9, $\mathrm{n}=$ 127. Branchiostegal rays 4, in 9 cleared and stained specimens, 3 rays originating on anterior ceratohyal and 1 ray on posterior ceratohyal.

Color in alcohol. See Figs. 29 and 30 for color pattern of males and females. Body pale to medium brown, pale yellowish brown ventrally, darker dorsally. Lateral body stripe diffuse throughout body length in both sexes, consisting of scattered dark chromatophores of fairly large size, extending from black, vertical humeral spot posteriorly to caudal fin and onto dorsal region of ventral caudal-fin lobe and basal part of dorsal caudal-fin lobe. Scattered pigmentation darker in males than in females or immatures. Caudal gland structures, including those derived from dorsal caudal-fin lobe such as modified caudal squamation with scattered dark chromatophores. Caudal pigmentation much paler in females and immatures. Remainder of caudal fin dusky due to scattered dark chromatophores in both sexes, but darkest in adult males. Dorsal border of first principal caudal-fin ray and ventral border of nineteenth principal caudal-fin ray black. Humeral spot vertically elongate, especially dark in sexually mature males, dusky in females and immatures. Dorsal most surface of body black, forming narrow dark stripe extending from supraoccipital region to base of dorsal procurrent rays of caudal fin. Dorsal area of back also with scattered small chromatophores, much smaller than chromatophores of diffuse lateral stripe. Body surface ventral to lateral stripe pale brown due to scattered dark chromatophores comparable to those forming lateral stripe. Abdomen white or yellowish white, without dark chromatophores.

Pectoral, pelvic, dorsal, and anal fins dusky with scattered small dark chromatophores along fin rays and on membranes. Anal fin with distally located dark elongate stripe (darker in males) running length of fin. Stripe width about one-fourth height of anal fin. Sexually mature males with stripe somewhat darker anteriorly, especially dorsal to anterior anal-fin lobe. Dorsal-fin with horizontal dark stripe 


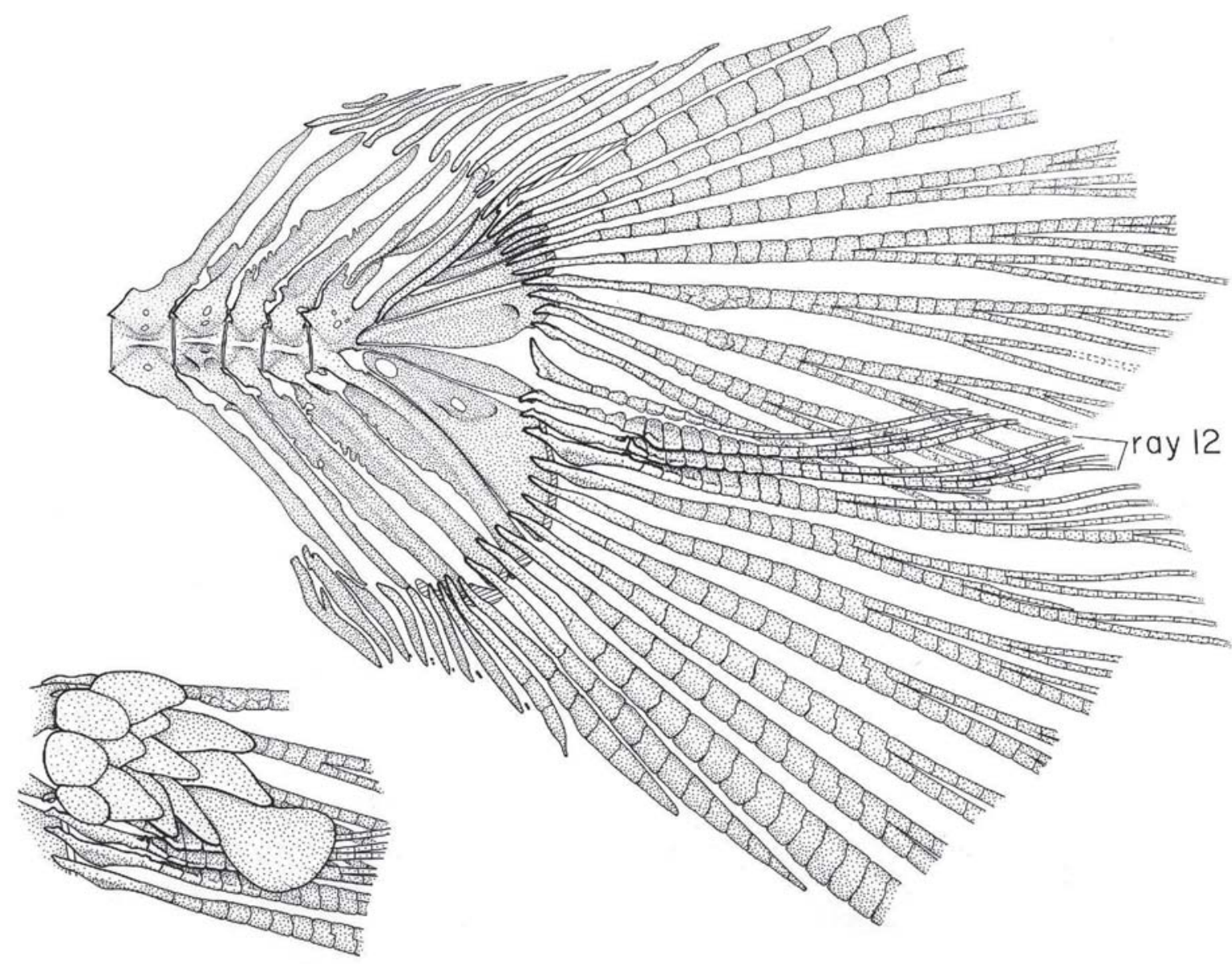

Fig. 32. Mimagoniates inequalis, adult male, MCP 9892, $37.0 \mathrm{~mm}$ SL; osteology of caudal skeleton and caudal-fin squamation (lower left inset) lateral view, left side. Cartilage represented by crosshatching.

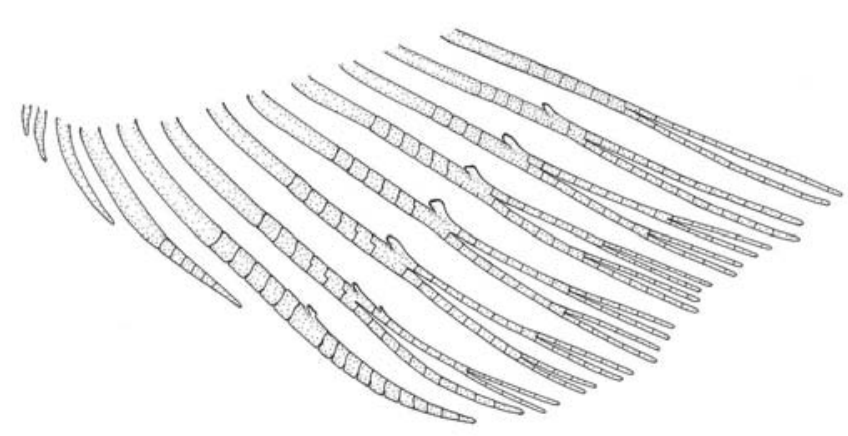

Fig. 33. Mimagoniates inequalis, adult male, MCP 9892, 37.0 mm SL; anterior 12 anal-fin rays, lateral view, left side. First branched ray bears two hooks.

in adults extending posteriorly from about mid-length of anterior elongate divided ray to posterior tips of two terminal dorsal-fin rays. Stripe relatively narrow, usually less than one-eighth maximum height of dorsal fin. Width and intensity of stripe varies with sex and sexual maturity, darker in males but always paler anteriorly. Adipose fin dusky with scattered dark chromatophores, darker in mature males than females

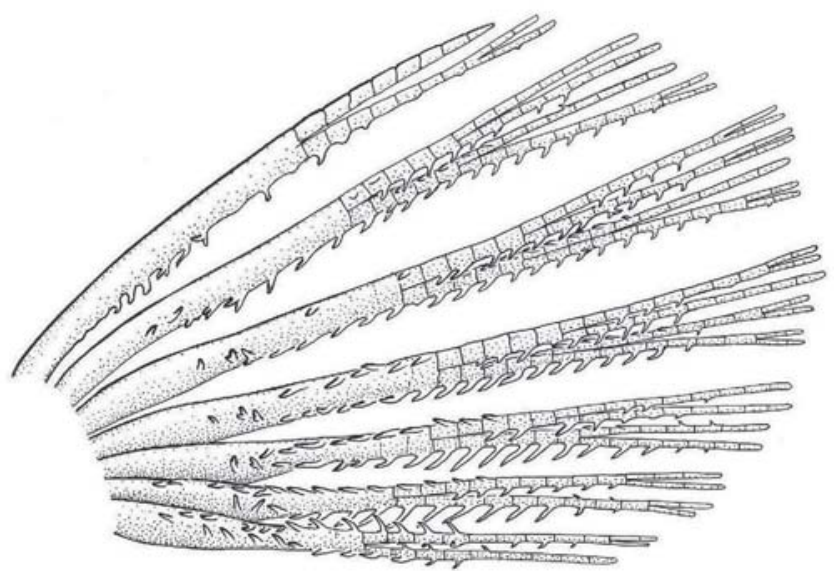

Fig. 34. Mimagoniates inequalis, adult male, MCP 9892, 37.0 mm SL; pelvic-fin rays, ventral view, left side.

and immatures.

Head brown around mouth, darker and almost black on dorsal surface of snout, between eyes, dorsal portion of head and nape. Tip of lower jaw dark brown. Scattered fairly large dark chromatophores on head area posterior to infraorbitals 


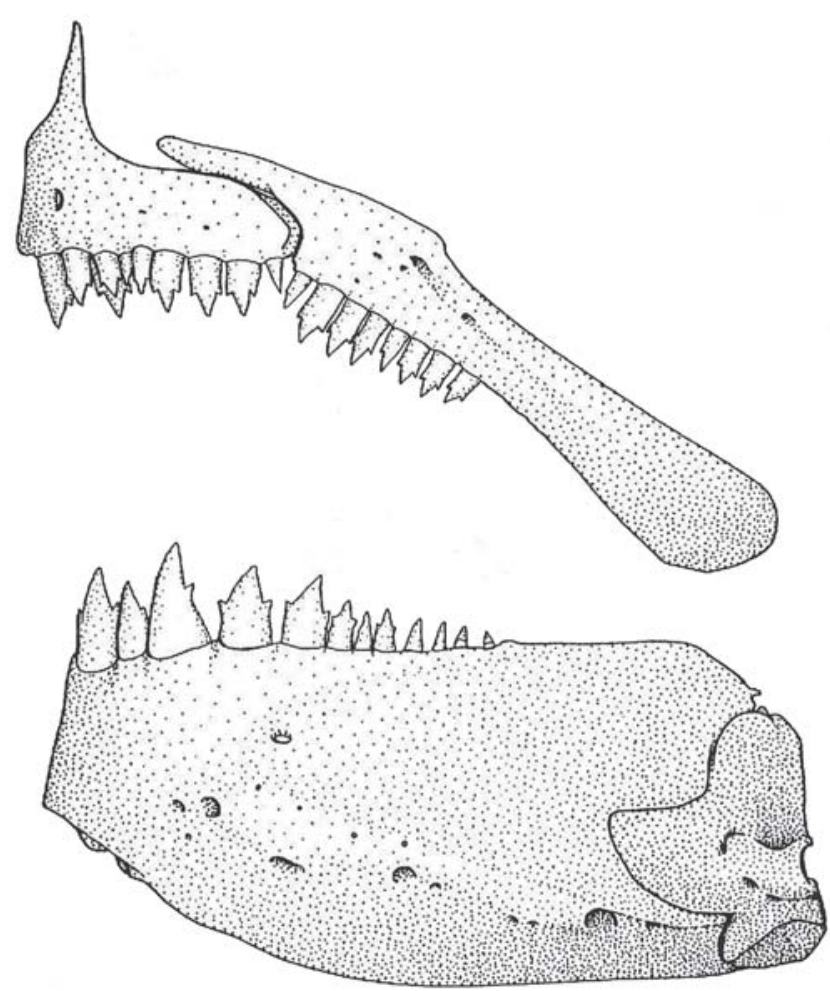

Fig. 35. Mimagoniates inequalis, adult male, MCP 9892, 37.0 $\mathrm{mm} \mathrm{SL}$; jaws and dentition, lateral view, right side, anterior at left.

and extending ventrally from parietal region, across dorsal opercular region pale with scattered fairly large dark chromatophores. Same color continues ventrally across posterior region of opercular bone to just reach interopercular bone. Iris dark brown dorsal to pupil, otherwise silvery or if silvery pigment absent dark, nearly black. Infraorbitals silvery if guanine preserved, pale yellowish brown when guanine absent. Dark brown chromatophores scattered evenly across circumorbital area. Anterior area of opercle, all of preopercle, and branchiostegal rays silvery or pale brown, with limited dark brown pigment.

Color in life. Life colors described here taken from a $35 \mathrm{~mm}$ color slide of specimen photographed just after capture from a blackwater stream (USNM 236424). Sides of body pale silvery blue. Broad diffuse lateral body stripe somewhat deeper silvery blue from black humeral spot to termination of caudal peduncle. Back darker blue to blue green color immediately dorsal to silvery blue color of body sides. Dorsal region of caudal peduncle faint yellow. Ventral abdominal area, most of lower jaw, ventral opercular area, branchiostegal rays and their membranes silvery white. Dark pigment of head similar to that in preserved specimens. Top of head black. Dorsal caudal-fin lobe and principal caudal-fin rays 14-16 on ventral caudal-fin lobe mostly hyaline but with a little dark red color along dark stripe of dorsal fin. Dorsal lobe of caudal-fin mostly hyaline with little reddish pigment on rays. Ventral lobe of caudal fin with considerable black pigment on rays in males, especially those rays radiating from caudal organ. Anal fin with distal portion of fin rays beyond dark anal-fin stripe hyaline to silvery yellow. Proximal portion of anal fin dorsal to black stripe, hyaline or with some silvery pigment. Approximately distal one-half of pelvic fin white with a black and reddish band proximal to this. Remaining proximal portion of pelvic fin hyaline. Distal onehalf of pectoral fins pale lemon yellow. Dorsal fin hyaline to white both distal and proximal to black and brown longitudinal stripe.

Sexual dimorphism. Females lack the caudal pheromone organ (Fig. 30), as well as the anal-fin and pelvic-fin hooks of males. Also females display more subdued live body coloration as noted above. Caudal peduncle depth and pelvic-fin length differ significantly between males and females (Table 6). However, when these morphometric characters were compared as a function of standard length through regression analysis, no significant differences were found. The samples include, however, very few mature males and females.

Distribution. Mimagoniates inequalis is known from small streams and rivers tributaries of rio Jacuí and lago Guaíba, from small streams flowing into laguna dos Patos, and from small isolated coastal ponds and streams flowing into the Atlantic Ocean in southern Rio Grande do Sul, Brazil. It was also collected in tributaries of the upper rio Negro, Rivera, Uruguay. See fig. 3 in Menezes et al. (2008).

Ecology. Immatures of this species are found in small, slowly moving blackwater streams in forested regions and in areas with sufficient vegetation to produce mild to extremely dark tea colored waters. Somewhat acid water low in salts appears to be one of this species ecological requirements. This is one of the first fish species to disappear once streams are polluted. A few mature specimens over approximately $28.0 \mathrm{~mm}$ SL were found in the same blackwater streams occupied by the smaller specimens but large adult males of up to approximately $38 \mathrm{~mm}$ SL are rarely taken in the wild.

Remarks. The glandulocaudins examined and reported by Schultz (1959) need critical discussion to clear up some of the confusion of the species names used in the texts and for the photographs published by Axelrod (1958), Harald Schultz (1959), and L. P. Schultz (1959). The collecting trip reported by Axelrod (1958) where specimens of Mimagoniates were collected, was in the region near Santos, in the state of São Paulo. Axelrod (1958: 13-15) noted that Mimagoniates species identifications were questionable. Collections available to us from this region indicate that two species of Mimagoniates occur there, M. lateralis from blackwater streams and M. microlepis from clear water streams. Axelrod (1958: 15 and the color photograph on page 12) discussed and illustrated a species of Mimagoniates found in black 
acid waters identified as M. microlepis by Harald Schultz that we identify as M. lateralis. Axelrod (1958: 17) reported but did not illustrate another species, called Mimagoniates barberi (?) from open waters. This is possibly M. microlepis. A color photograph on page 13, illustrates two specimens identified as $M$. inequalis. The fish pictured at the left is probably an adult $M$. inequalis because the dark stripe on the anal fin does not closely approach the distal margin of the fin, especially anteriorly. The specimen at right is most probably an immature moderate-sized specimen of $M$. microlepis because the dark anal-fin stripe does closely approach the distal margin of the fin. Mimagoniates inequalis is unknown from the region near Santos and the photograph is likely one that Harald Schultz made of specimens collected in Rio Grande do Sul State. Axelrod (1959: 39) mentions collecting a species of Mimagoniates on another expedition, this time to Rio de Janeiro State, but no photographs or comments were made about the species. This species would be been $M$. microlepis, the only species to occur in this state according information at hand.

Harald Schultz (1959) discussed the species of Mimagoniates and Glandulocauda but seemed aware of only three species, M. barberi, M. microlepis and $G$. inequalis. In this publication Schultz recognized $M$. lateralis as $M$. barberi (the name often used at that time for $M$. lateralis in the European and American ornamental fish trade). The photograph labeled as of $M$. barberi is of $M$. lateralis. Schultz (1959) correctly gives the range of what he designates as $M$. barberi as found in blackwater streams from the city of Santos south to the State of Santa Catarina. This time he appears to have correctly identified $M$. microlepis and states that it is found in the coastal plains from north of Rio de Janeiro south to Paraná and Santa Catarina States, a range nearly equal to that recorded below for that species. Schultz (1959: 52) found $G$. inequalis (= $M$. inequalis of the present report) south of the range of $M$. microlepis in Rio Grande do Sul State. He found $M$. inequalis and $M$. microlepis only in clear water. Interestingly in regard to Menezes \& Weitzmann (1990: 416-422) discussion of the possible hybrid origin of $M$. rheocharis, Schultz found both $M$. inequalis and $M$. microlepis living together. (see discussion under $M$. rheocharis). A jar of 14 specimens of M. inequalis plus one of M. microlepis, USNM 177704 (all identified as M. inequalis by L. P. Schultz, 1959: 63), and said to be collected in Porto Alegre might tend to confirm this overlap in geographical range. There is no information that all these specimens are from one locality near Porto Alegre. The lot was entered into the USNM catalog on 4 February, 1959, and the fishes were collected sometime previous to that date.

Another sample of Mimagoniates, USNM 177703, listed as collected in Porto Alegre, and identified by Schultz (1959: 11 ) as $M$. microlepis, is rather $M$. lateralis. The known southern most locality for $M$. lateralis is Santa Catarina State, rio Vermelho, Barra do Sul in Ilha de São Francisco, about 35 km from Joinville, SC, $26^{\circ} 14^{\prime}$ S $48^{\circ} 35^{\prime}$ W, a location far from
Porto Alegre, RS. This raises question to the locality information for USNM 177703 and 177704.

Material examined. Holotype. FMNH 54893, adult male, 32.6 mm SL; Brazil, Rio Grande do Sul, Porto Alegre, (rio Guaíba “in front of town” see Eigenmann, 1911a: 308), approximately $30^{\circ} 02^{\prime} \mathrm{S}$ $51^{\circ} 12^{\prime} \mathrm{W}$. See notes below on type locality. Paratypes. Collected with holotype: FMNH 54894, immatures, 4, 21.6-25.6 mm SL; CAS(IUM) 13270, adult female, $29.8 \mathrm{~mm} \mathrm{SL}$, adult male, $31.5 \mathrm{~mm}$ SL. Non-Types. All collected in Brazil, Rio Grande do Sul, rio Guaíba basin: USNM 94310, adult males 3, adult female 1, 29.5$41.5 \mathrm{~mm}$ SL, aquarium specimens reported to have been imported into Germany from Porto Alegre, Rio Grande do Sul; USNM 177704, immature to adults 14, 17.6-35.4 mm SL, Porto Alegre, (Schultz, 1959: 63 listed 15 specimens; largest specimen is M. microlepis; see “Remarks" below under $M$. inequalis concerning locality information of lot); MCP 9892, adult females 2, 33.4-37.9 mm SL, município de Triunfo, “near rio Caí”, 30; MZUSP 75515, immature to adult 2, 24.7-32.2 mm SL, município de São Leopoldo, fazenda São Borja; MAPA 811, 40 young to adults, município Gravataí, tributary to rio Gravataí at Morungava (between Gravataí and Taquara) northeast of Porto Alegre, rio Gravataí flows into rio Jacuí near mouth of latter; USNM 313489 (erroneously MCP 9892 in Weitzman et al., 1988: 402), young to adult male, c\&s, 24.4-37.0 SL, same data as MAPA 811; USNM 236423, small adults 38, 13.6-29.1 mm SL, município de Viamão, southeast of Porto Alegre, riacho Passo Comprido, a tributary to arroio Fiúza, approximately $30^{\circ} 10^{\prime} \mathrm{S} 51^{\circ} 00^{\prime} \mathrm{W}$; USNM 257116 , young to juveniles 42 , 14.2$22.4 \mathrm{~mm}$ SL, same locality data as USNM 236423; USNM 254273, young to juveniles 39, 15.9-26.6 mm SL, same data as USNM 236423; USNM 236424 (erroneously USNM 234161 in Weitzman \& Fink, 1985: 106), young to maturing adults 34, 13.2-30.5 mm SL, município de Montenegro, arroio Passo da Cria along Passo da

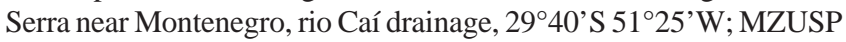
26908, young to adults $24,14.3-24.6 \mathrm{~mm} \mathrm{SL}$, same locality data as USNM 236424; USNM 254275, young to adults 44, 16.0-26.6 mm SL, município de São Sebastião do Caí, arroio Paradiso, on road between São Sebastião do Caí and Bom Princípio; USNM 236090, immatures to adults 5, 24.8-27 mm SL, c\&s, same locality data as USNM 254275; MZUSP 19942, young to juveniles 55, 14.3-21.7 mm SL, same locality data as USNM 425275; MNRJ 26440, young to juveniles 52, 14.4-23.3 mm SL, same data as USNM 254275; USNM 254274, young to juveniles 30, 14.9-26.4 mm SL, município de Pelotas, arroio de Pelotas at bridge of road BR-116, north of Pelotas, approximately $31^{\circ} 39$ 'S 52¹9'W; USNM 254271, juvenile 1, 20.5 mm SL, município de Rio Grande, arroio Bolacha at crossing of road between Rio Grande and Cassino, 32 ${ }^{\circ} 10^{\prime}$ 'S $52^{\circ} 10^{\prime} \mathrm{W}$; USNM 254270, young to juveniles 9, 17.9-23.0 mm SL, município de Rio Grande, north end of banhado do Tigre, from a small stream crossing the road between fazenda Caçapava and Estação Ecológica do Taim, approximately 32 $36^{\prime} \mathrm{S} 52^{\circ} 37^{\prime} \mathrm{W}$; UFRGS 3946, immatures to adults 11, 18.1-27.5 mm SL, lagoa Emboaba, Tramandaí; USNM 326754, immatures 2, 25.4-27.8 mm SL, canal between lagoa Emboaba and lagoa Emboabinha on the road to Osório-Tramandaí, near Tramandaí; MZUSP 83355 immatures 3, 16.0-24.5 mm SL, tributary of rio Morungava in town of Morungava; USNM 326755, immatures to adults 4, 15.5, $26.8 \mathrm{~mm}$ SL, streams in município de Belém Novo, south of Porto Alegre. Uruguay, Rivera: USNM uncatalogued, immatures to adults 5, 21.2-32.0 mm SL, Cañado, 31¹1'60”S 554'ㄱ' 'W by P. Laurino, T. Litz et al., 25 Aug. 2004; USNM uncatalogued, immatures to adults 9, SL 17.9-31.8 mm, 31 $05^{\circ} 03^{\prime \prime} \mathrm{S}$ 554' $27^{\prime}$ 'W. 


\section{Mimagoniates barberi Regan, 1907}

Fig. 36

Mimagoniates barberi Regan, 1907: 402 (type locality: arroyo Yâcá, Estación Caballero, Paraguay, fig. 6). - Myers, in Eigenmann \& Myers, 1929: 492-493 (distinction between $M$. barberi and $M$. microlepis unclear; uncertain of validity of M. barberi). Pearson, 1937: 108 (M. barberi as endemic to Paraguay basin). - Travassos, 1952: 93 (listed). - Schultz, 1959: 63 (designated lectotype; recognized as a distinct species). - Nelson, 1964a: 64 (recognized M. barberi as valid species). - Géry, 1964: 6 (recognized M. barberi as possible geographic form of M. microlepis). - Géry, 1966: 228, 230 (recognized as distinct species). - Géry, 1977: 362 (recognized as distinct species). - Weitzman \& Fink, 1985: 105 (in materials examined). - Weitzman et al., 1988: 404 (phylogeny, biogeography, figure). - Menezes \& Weitzman, 1990: 385 (in key). - Houtan, 1990: 9 (aquarium description; color photograph). - Vari \& Howe, 1991: 30 (listed in type catalog). - Pecio \& Rafiñski, 1994: 180 (histological and ultrastructure of testes). - Weitzman \& Menezes, 1994: 3 (general discussion for non-systematic readers). Weitzman et al., 1996a: 209 (courtship behavior). - Weitzman et al., 1996b: 203, 204 (breeding and rearing). - Malabarba \& Weitzman, 2000: 279 (listed in discussion). - Weitzman, 2003: 226 (maximum length; distribution; remarks and references). - Britski et al., 2007: 68 (diagnosis; figure). Menezes et al., 2008: 38-42 (distribution; discussion of relationships and biogeography).

Mimagoniates microlepis Schultz, 1959: 11 (in part, 1 specimen of $M$. barberi in USNM 86296, misidentified as $M$. microlepis).

Diagnosis. Males of Mimagoniates barberi, M. pulcher n. sp., and $M$. inequalis have a rudimentary caudal-fin ray pump (Figs. 32, 38, and 47) and in this respect differ from males of their congeners which have a fully developed caudal-fin ray pump (Figs. 58, 67, 75, and 85). Mimagoniates barberi can be distinguished from $M$. inequalis by having more branched analfin rays (30-36 vs. 23-30), more scales in lateral series (41-48 vs. 34-41), fewer scale rows between dorsal-fin origin and anal-fin origin (13-15 vs. 15-18) and the mid-lateral dark stripe of adult males nearly black ( $v s$. lateral body stripe of adult males diffuse, poorly developed, often not apparent). Mimagoniates barberi differs from $M$. pulcher by the number of branched anal-fin rays (30-36 vs. 26-30) and by the absence of spines on principal caudal-fin rays (Fig. 38), present in M. pulcher (Fig. 47).

Description. Table 7 presents morphometrics of the holotype, paratypes, and other specimens. Description refers to all population samples combined except where noted. These collections were treated statistically as one population sample to represent the species as a whole.

Body compressed, relatively elongate; body deepest at vertical through anal-fin origin. Predorsal body profile gently convex and slightly more arched in adult males. Body profile
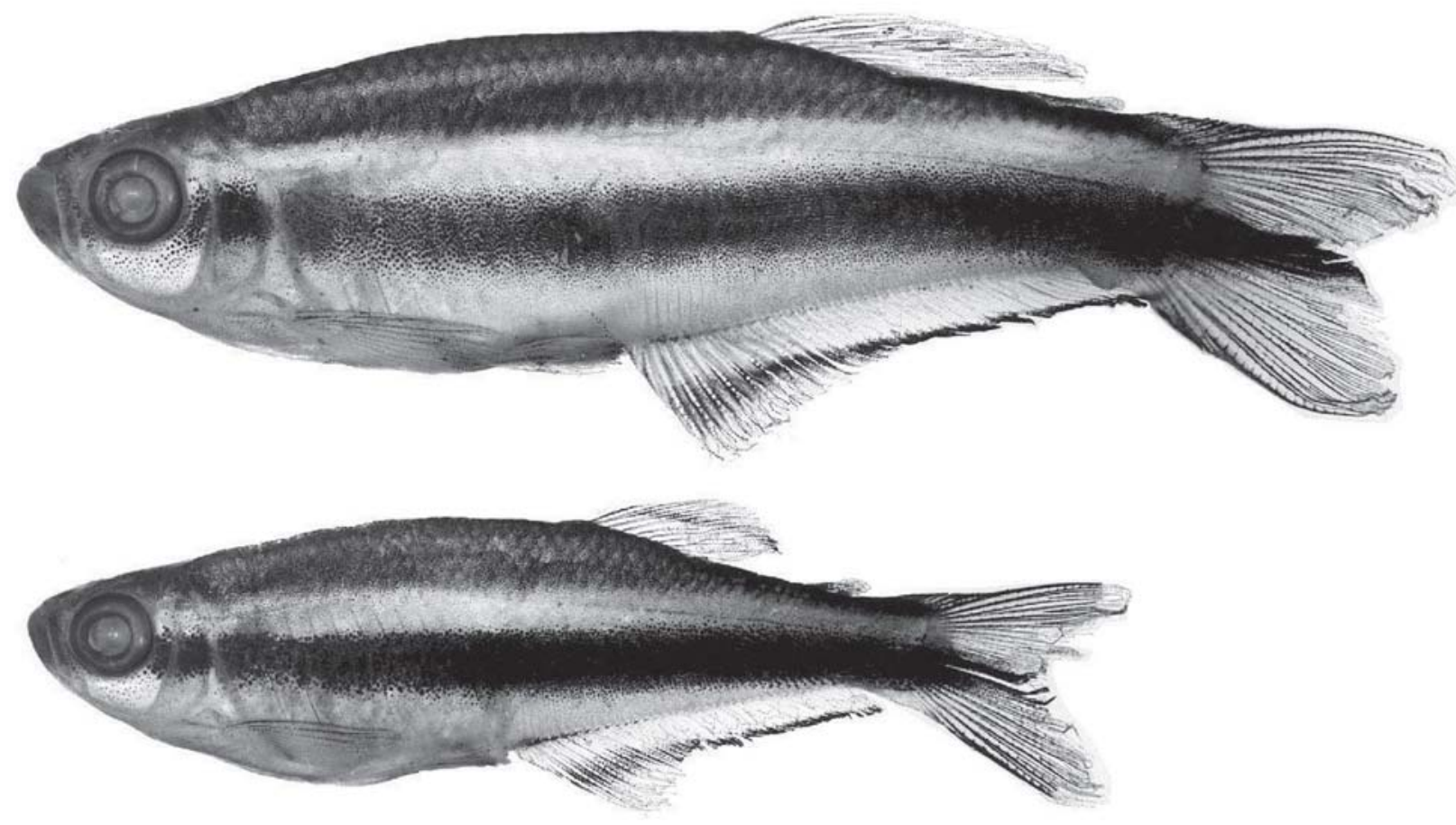

Fig. 36. Mimagoniates barberi, male above, UMMZ 205420, 35.6 mm SL, female below, SL 26.8 mm, Paraguay, San Pedro, rio Aguarai-mi, tributary to rio Paraguay, paratypes. 
Table 7. Morphometrics of Mimagoniates barberi. Standard length is expressed in mm; measurements through bony head length are percentages of standard length; the last four entries are percentages head length. A plus sign under the abbreviation dif. indicates there is a significant statistical difference between the males and females in the particular character indicated. All specimens in this table are a combination of all localities recorded for this species: BMNH 1990.9:2 (lectotype), BMNH 1907.10.226-8 (paralectotypes); USNM 179827 (paralectotypes); USNM 327586; UMMZ 205415, UMMZ 205417, UMMZ 205418, UMMZ 205420; MHNG 2241.78, MHNG 2477.61, 21-22, MHNG 2481.90, MHNG 2481.91. SD = Standard deviation.

\begin{tabular}{|c|c|c|c|c|c|c|c|c|c|c|}
\hline \multirow{2}{*}{ Characters } & \multicolumn{5}{|c|}{ Males } & \multicolumn{4}{|c|}{ Females and juveniles } & \multirow[b]{2}{*}{ dif. } \\
\hline & Holotype & $\mathrm{N}$ & Range & Mean & SD & $\mathrm{N}$ & Range & Mean & SD & \\
\hline Standard length & 33.1 & 36 & $19.0-33.2$ & 25.1 & & 38 & $17.4-27.0$ & 22.6 & & \\
\hline Depth at dorsal-fin origin & 26.3 & 36 & $31.0-28.0$ & 24.7 & 1.7 & 38 & 21.4-27.7 & 23.6 & 1.5 & - \\
\hline Snout to dorsal-fin origin & 62.2 & 36 & $60.4-66.6$ & 62.4 & 1.4 & 38 & $59.5-65.4$ & 62.4 & 1.6 & - \\
\hline Snout to pectoral-fin origin & 25.7 & 36 & 23.4-28.6 & 25.7 & 1.0 & 38 & $23.4-26.3$ & 25.0 & 0.8 & - \\
\hline Snout to pelvic-fin origin & 42.0 & 36 & $39.4-44.9$ & 42.8 & 1.2 & 38 & $41.0-46.8$ & 43.2 & 1.4 & - \\
\hline Snout to anal-fin origin & 54.4 & 36 & $52.1-57.7$ & 54.7 & 1.3 & 38 & $51.9-58.7$ & 55.4 & 1.4 & - \\
\hline Caudal peduncle depth & 16.0 & 36 & $11.3-16.0$ & 12.6 & 1.6 & 38 & $08.8-12.4$ & 10.5 & 0.9 & + \\
\hline Caudal peduncle length & 09.1 & 36 & $06.4-10.4$ & 08.5 & 0.8 & 38 & 07.3-09.4 & 08.3 & 0.5 & - \\
\hline Pectoral-fin length & 21.8 & 36 & $20.0-24.4$ & 21.5 & 1.1 & 38 & $18.9-22.7$ & 20.9 & 0.9 & - \\
\hline Pelvic-fin length & 14.0 & 36 & $12.1-15.9$ & 13.6 & 0.9 & 38 & 08.9-13.1 & 11.7 & 1.0 & + \\
\hline Dorsal-fin base length & 13.9 & 36 & $11.4-14.9$ & 13.2 & 0.8 & 38 & $10.8-14.5$ & 12.4 & 1.0 & - \\
\hline Dorsal-fin height & 29.6 & 35 & $20.5-30.9$ & 25.2 & 2.7 & 34 & $18.0-25.7$ & 22.1 & 1.9 & + \\
\hline Anal-fin base length & 39.0 & 36 & $36.0-40.9$ & 39.0 & 1.2 & 38 & $37.2-41.6$ & 38.8 & 1.0 & - \\
\hline Anal-fin lobe length & 19.9 & 36 & $14.5-21.4$ & 18.4 & 2.0 & 35 & 16.0.21.1 & 18.3 & 1.2 & - \\
\hline Eye to dorsal-fin origin & 51.3 & 35 & $48.0-53.8$ & 50.1 & 1.5 & 38 & $45.7-51.3$ & 49.7 & 1.4 & - \\
\hline Dorsal-fin origin to caudal-fin base & 43.5 & 36 & $37.8-43.5$ & 40.8 & 1.6 & 38 & $36.0-43.9$ & 40.0 & 1.8 & - \\
\hline Bony head length & 24.8 & 36 & $21.7-26.8$ & 24.7 & 1.1 & 38 & $21.7-25.8$ & 24.1 & 1.0 & - \\
\hline Horizontal eye diameter & 35.4 & 36 & $34.2-45.8$ & 40.5 & 3.4 & 38 & $36.6-47.6$ & 42.9 & 2.8 & - \\
\hline Snout length & 25.6 & 36 & $18.6-26.4$ & 23.0 & 1.8 & 38 & 19.2-26.9 & 22.8 & 1.9 & - \\
\hline Least interorbital width & 31.7 & 36 & $31.7-38.4$ & 36.1 & 1.6 & 38 & $32.2-40.4$ & 36.6 & 1.8 & - \\
\hline Upper jaw length & 42.7 & 36 & $38.1-44.2$ & 42.2 & 1.8 & 38 & 38.3-44.9 & 41.6 & 1.7 & - \\
\hline
\end{tabular}

slightly elevated at dorsal-fin origin. Dorsal profile of body nearly straight along dorsal-fin base and to adipose fin. Body profile posterior to adipose fin slightly concave dorsal to caudal peduncle, ending at origin of procurrent caudal-fin rays. Dorsal-fin origin nearer to caudal-fin base than to snout tip. Ventral profile of body convex in adults from tip of lower jaw to origin of pelvic fins, somewhat less convex in juveniles. Abdominal profile in adult males slightly concave between pelvic-fin origin and anal-fin origin, straight or nearly so in females and juveniles. Body profile along anal-fin base nearly straight in all specimens. Ventral profile of caudal peduncle convex in adult males; slightly concave or nearly straight in females and juveniles.

Lower jaw protruding beyond upper jaw. Lower jaw of adults thick and heavy compared to that of juveniles. Mouth slightly angled posteroventrally. Maxilla long, extending to point well ventral to horizontal through ventral border of eye in all specimens. Maxilla extends posteriorly to point anterior to vertical through anterior border of pupil of eye.

Dorsal-fin rays ii in all specimens, branched rays 7-8 (8), 8, $\mathrm{n}=77$; posterior ray not split to its base and counted as 1 . Adipose fin elongate, slender (Figs. 36 and 37). Anal-fin unbranched rays iv or v, usually iv, branched rays 31-36 (33), $33.1, n=74)$; posterior ray split to its base and counted as 1 . Anal fin with moderately developed lobe anteriorly (Figs. 36 and 39); lobe includes fourth unbranched and first 4 branched rays. Anal fin of sexually mature males with bilateral hooks, (1) on each side, on last unbranched ray (iv or v), (Fig. 39). Anterior (7) branched fin rays usually with bilateral hooks, 1 set for each ray. Pectoral-fin unbranched ray i in all specimens, branched rays 8-11 (10), 9.5, $\mathrm{n}=77$ ). Tip of pectoral extends posteriorly beyond origin of pelvic fins. Pelvic fin rays 6-7 (i, 7 ), $n=77$. Pelvic fin with anterior (first) ray unbranched or branched (branches well separated and often posterior branch divided at tip or for its distal half (Fig.40). Sexually mature, large adult males with over 220 hooks on each pelvic fin distributed as shown in Fig. 40.

Principal caudal-fin rays 10/9 in all specimens, $(n=77)$. Modification of some rays in association with caudal pheromone pump as in Figs. 38a and b. Fin rays modified more like those in $M$. inequalis than any other species of Mimagoniates.

Scales cycloid, with few radii along posterior border. Terminal scales of modified caudal-fin series without exaggerated radii (Fig. 38b).

Lateral line incomplete, perforated scales 5-10 (8), 7.2, $n=$ 41. Lateral series scales 40-49 (44), 44.6, $n=39$. Predorsal scales 21-29 (24), 24.5, $n=42$. Scale rows between dorsal-fin and anal-fin origins $13-15$ (15), $14.5, \mathrm{n}=48$. Scale rows around caudal peduncle 15-17 (16), 16.0, $\mathrm{n}=30$.

Premaxillary teeth in 2 irregular, closely packed rows (Fig. 41). Determining teeth in each row impossible except in cleared and stained specimens. Thus all teeth on left premaxilla given as total. Teeth tricuspid in all large specimens, small teeth in smaller specimens sometimes bicuspid or conical. Total premaxillary teeth 7-10 (8), 8.5, $\mathrm{n}=68$. Outer and inner row premaxillary teeth somewhat compressed. Maxillary teeth 3-7 (4), 4.5, $n=75$. All maxillary teeth tricuspid in large specimens 
(Fig. 41); small specimens with posterior maxillary teeth often conical. Dentary with 4-5 (4), 4.1, large tricuspid teeth; posterior dentary teeth 4-9 (8), 6.8, with nearly always more teeth in largest specimens; anterior small dentary teeth tricuspid, posterior ones conic, $n=77$ (Fig. 41). Maxillary and dentary teeth shaped much like premaxillary teeth. No significant difference in tooth number found between males and females.

Vertebrae 41-43 (42), 42.4, $\mathrm{n}=19$. Dorsal limb gill rakers 57 (7), 6.2, $n=19$; ventral limb gill rakers 11-13 (12), 12.3, $n=58$. Branchiostegal rays 4, in 1 cleared and stained specimens, with 3 rays originating on anterior ceratohyal and 1 ray from posterior ceratohyal.

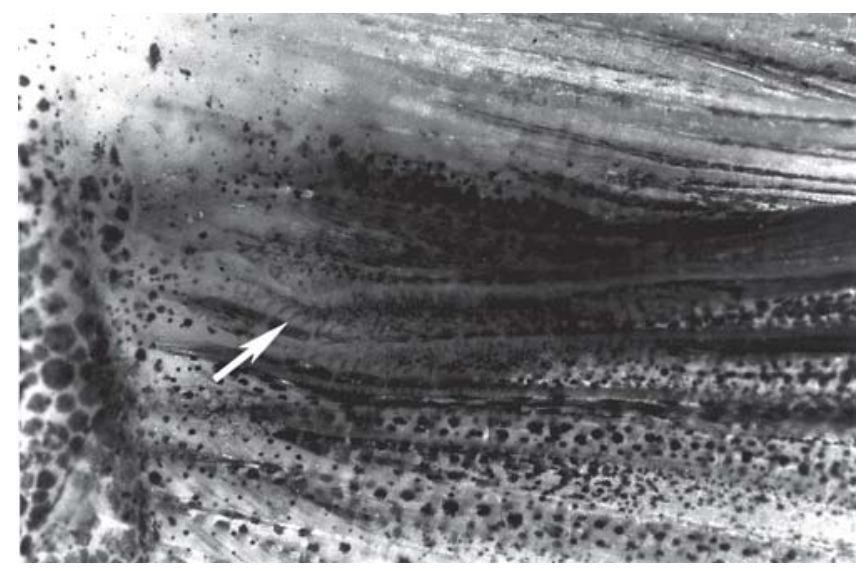

Fig. 37. Mimagoniates barberi, male, USNM 327586, $32.7 \mathrm{~mm}$ SL; central region of caudal-fin base and fin showing beaded tissue indicated by arrow, especially along borders of rays 11 and 12 , the rays that border groove of primitive caudal pump. Modified from Menezes \& Weitzman (1990).

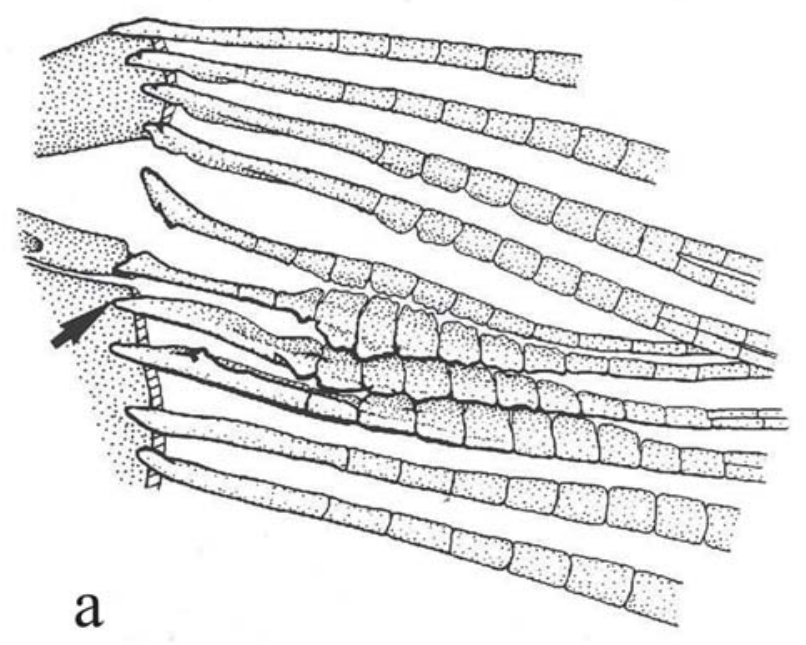

Color in alcohol. See Fig. 36 for preserved color pattern of males and females. Body pale to medium brown, pale yellowish-brown ventrally, darker to much darker dorsally. Longitudinal body stripe prominent along length on body. Stripe extending from border of eye to caudal fin base and in males onto portion of caudal fin occupied by caudal organ. Comparable area on caudal fin of females also black. Remainder of caudal fin dusky due to scattered dark chromatophores, especially on fin rays. Dorsal border of first principal caudalfin ray and ventral border of nineteenth principal caudal-fin ray usually darker than other caudal fin rays. Lateral stripe extends over all caudal gland structures. Stripe especially dark on principal rays 10,11 and 12, less so on ray 13 . Humeral spot barely distinguishable from anterior portion of horizontal body stripe, but present just posterior to posterior opercular border. Dorsal body surface very dark, nearly black, forming narrow stripe extending from supraoccipital region to base of dorsal procurrent rays of caudal fin. Second dark longitudinal body stripe extends from nape across body, continuing to base of upper dorsal-fin lobe. Stripe lies just dorsal to pale longitudinal stripe extending just dorsal to first longitudinal dark stripe. Remainder of body surface ventral to first longitudinal body stripe pale brown.

Pectoral, pelvic, dorsal, and anal fins dusky with scattered dark chromatophores along fin rays and, to lesser extent, on membranes. Anal fin with dark elongate stripe running length of fin. Stripe width about one fourth height of anal fin anteriorly and about less than one-fourth of height posteriorly. Stripe narrower posteriorly than anteriorly, and of uniform width for posterior one-half of fin where it borders ventral edge of fin. Stripe darker posteriorly. In sexually mature males stripe broadens anteriorly where it is relatively pale, but covers much of surface of fin with anal-fin spines. Distal portion of anal-fin

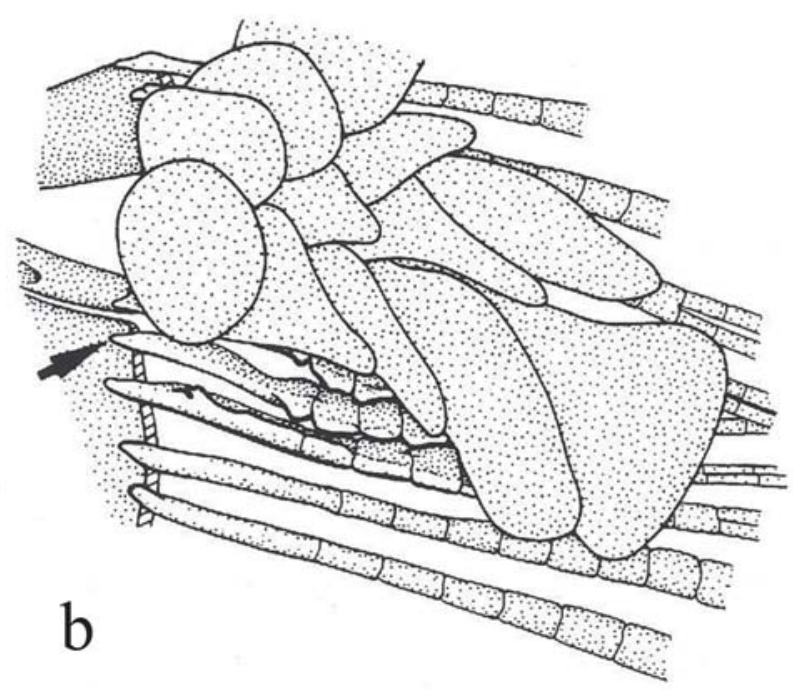

Fig. 38. Mimagoniates barberi, adult male, UMMZ 205420, $35.6 \mathrm{~mm}$ SL; osteology of central basal region of caudal skeleton, principal caudal-fin rays 6-15, lateral views, left side, anterior is at left. Principal ray 12 indicated by arrow. (a) Illustrates glandular groove between rays 11 and 12. (b) Illustrates relationship of modified dorsal caudal-fin lobe squamation to glandular groove. Modified scales together their epidermis form movable flap just lateral to surface of rays and groove that bear most of glandular tissue. Modified from Menezes \& Weitzman (1990). 
lobe relatively hyaline. Dorsal fin with horizontal dark stripe in adult males and females extending posteriorly from about mid-length of anterior elongate undivided ray to posterior tips of two terminal dorsal-fin rays. Stripe usually narrow, less than one-eighth maximum height of dorsal fin. Width and intensity of stripe somewhat variable depending on sex and maturity. Adipose fin dusky with scattered dark chromatophores.

Head dark brown around mouth and on dorsal surface of snout, between eyes, dorsum of cranium and nape. Tip of lower jaw dark brown. Portion of head posterior to infraorbitals and extending ventrally from parietal region, across dorsal opercular region pale except where first horizontal stripe extends to eye. Iris dorsal to pupil more or less silvery. Infraorbitals silvery if guanine preserved, pale yellowish brown if guanine absent. Dark brown chromatophores not dense, but scattered evenly through circumorbital area. Anterior area of opercle, all of preopercle, and branchiostegal rays silvery or pale brown, without much dark brown pigment except in area of first horizontal longitudinal stripe.

Color in life. Life colors described here taken from aquarium specimen, USNM 327586, taken from within 50 miles Asunción. Specimen in preservative shown in Fig. 36. Sides of body pale silvery blue. Broad lateral body stripe somewhat deeper silvery blue extends immediately dorsal to silvery blue color of body sides from humeral spot to caudal peduncle termination. Back with narrow dark brown line extending from parietal region of head to just ventral to adipose fin. Lateral portion of dorsolateral portion of body brownish-yellow green color between narrow brown line and dorsomedian narrow dark brown line extending across dorsal most portion of back. Dorsal region of caudal peduncle nearly yellow. Ventral abdominal area, most of lower jaw, ventral opercular area, branchiostegal rays and their membranes silvery white. Dark pigment of head similar to that described for preserved specimens except that dorsal region of opercle appears silvery blue. Dorsal caudal-fin lobe and principal caudal-fin rays 1416 on ventral caudal-fin lobe bright yellow, except for black

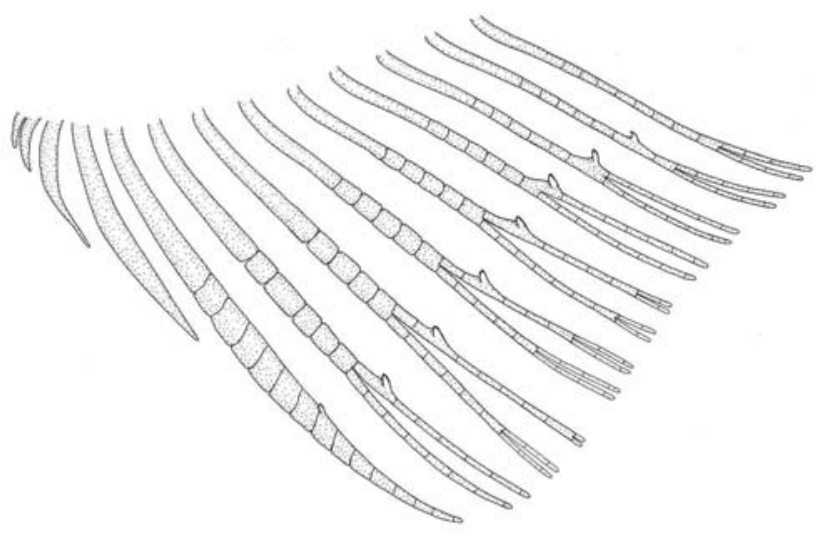

Fig. 39. Mimagoniates barberi, adult male, UMMZ 205420, $32.7 \mathrm{~mm}$ SL; anterior 13 anal-fin rays, lateral view, left side. proximal half of ray 14 . Black pigment continuous with black pigment surrounding structures of caudal pheromone organ. Rays 17-19 on ventral caudal-fin lobe hyaline or nearly hyaline except ray 17 which is somewhat yellow. Remainder of black pigment of caudal fin as described in preserved specimens. Anal fin with distal portion of fin rays posterior to anterior anal-fin lobe lemon yellow, forming a stripe along ventral border of fin. Distal region of anterior anal-fin lobe hyaline to white,

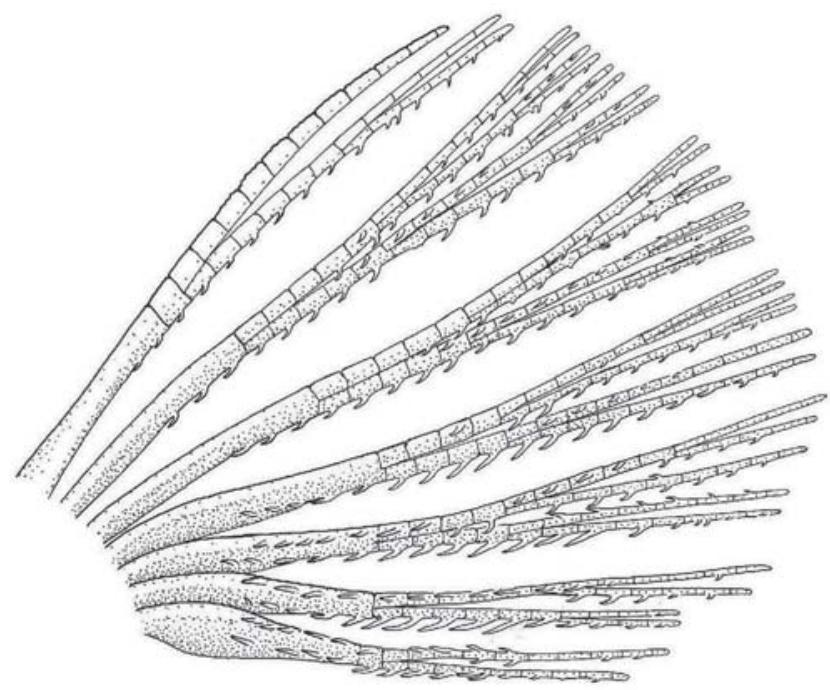

Fig. 40. Mimagoniates barberi, adult male, UMMZ 205420, 32.7 mm SL; pelvic-fin rays, ventral view, left side.

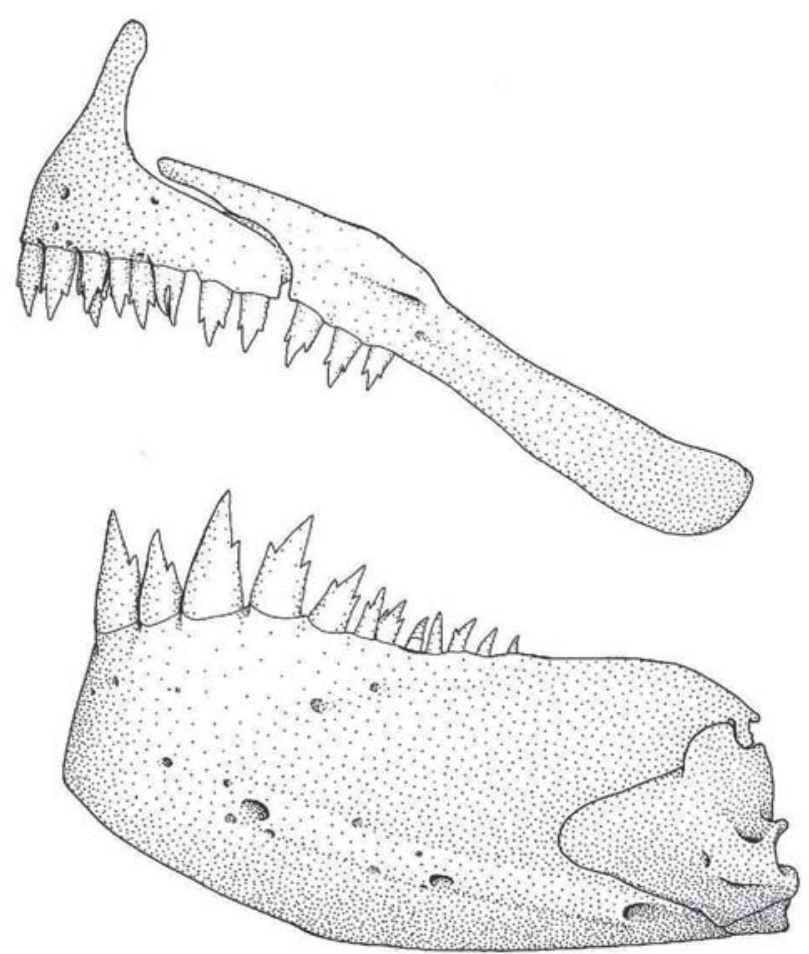

Fig. 41. Mimagoniates barberi, adult male, UMMZ 205420, $35.9 \mathrm{~mm}$ SL; jaws and dentition, lateral view, right side, anterior at left. 
proximally bordered by black pigment described above in preserved specimens. Basal half of anal fin hyaline with some scattered brown chromatophores and a small tint of yellow anteriorly. Posterior portion of narrow horizontal black line of anal fin pale. Approximately distal one-half of pelvic fin white, with black and yellow band proximal to this and remaining proximal portion of fin hyaline. Distal one-half of pectoral fins yellow, proximal half with black rays and yellow membranes. Dorsal fin hyaline to white distal and proximal to longitudinal black and brown longitudinal stripe.

Distribution. Known from left bank tributaries of río Paraguay and tributaries of rio Paraná, near Foz do Iguaçu, in Paraguay. See figure 3 in Menezes et al. (2008).

Ecology. Field notes taken by R. M. Bailey and J. N. Taylor indicate that specimens collected in southern Paraguay (UMMZ 205417, UMMZ 205418 and UMMZ 205420) were found in small tributaries (arroyos), rivers (ríos) and pools. Two specimens (UMMZ 205415) were collected from a brown colored stream, visibility of about $0.3 \mathrm{~m}$, surrounded by partly wooded ravine. The current at the collecting site was 0.3-0.5 $\mathrm{m} /$ second. Other two specimens (UMMZ 205418) were caught from green clear waters, visibility of $10 \mathrm{~m}$, located also in a partly wooded ravine.

Sexual dimorphism. Females lack the caudal pheromone pump organ, anal-fin and pelvic-fin hooks of males. Table 7 indicates that some morphometric characters differ significantly between males and females. Regression statistics, however, indicated that only those related to pelvic-fin length, dorsalfin height and caudal peduncle depth are statistically significant. Figures 42 to 44 indicate that males reach longer lengths than the females. Figure 42 graphically indicates that males and females of $M$. barberi show significant sexual dimorphism in pelvic-fin length, but in males growth of pelvic fin is continuous following the model of a regression line $\left(\mathrm{r}^{2}=\right.$ 0.903 ) whereas in females the pelvic fin grows at a different rate not following the linear regression model $\left(r^{2}=0.06\right)$. Figure 43 provides graphic evidence that there is a slight divergence in dorsal-fin height between males and females as they become sexually mature and increase in length. Figure 44 also indicates a divergence in caudal peduncle depth beginning around 20.0 mmSL.

Material examined. Lectotype. BMNH 1907.10.22:5, adult male, 33.1 mm SL, Paraguay, (arroyo Yâca [= Yhaca, also Yaca], near Estación Caballero; arroyo Yhaca is at $25^{\circ} 39^{\prime} \mathrm{S} 5^{\circ} 53^{\prime} \mathrm{W}$ and Caballero is at $25^{\circ} 40^{\prime} \mathrm{S} 56^{\circ} 49^{\prime} \mathrm{W}$. Paralectotypes. Collected with lectotype: BMNH 1907.10.22:6-8, young adult female, 2 adult males, 23.7-29.5 mm; BMNH 1990.10.9:1, young male, SL 25.8 mm SL (Note: this specimen found in original type series but not catalogued until 1990); USNM 179827, young-adult, 2 females, 24.2-29.7 mm SL. Non-types. All collected in Paraguay unless otherwise noted. UMMZ 205420, 2 adult males, 5 young-adult females, 23.6-34.5 mm SL, c\&s 1 adult male 35.6 mm, San Pedro, río Aguaray-mi at bridge on dirt highway $2.1 \mathrm{~km} \mathrm{~N}$ of junction with

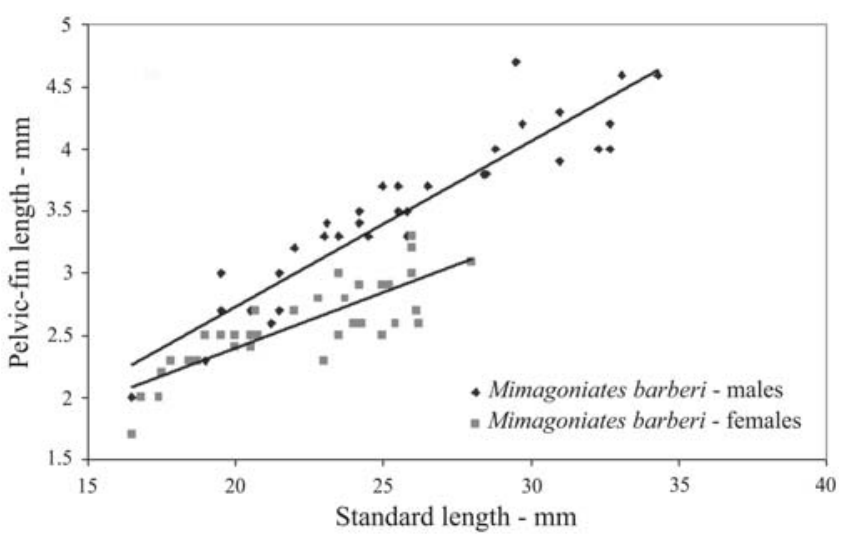

Fig. 42. Mimagoniates barberi, pelvic-fin length as function of SL by sex.

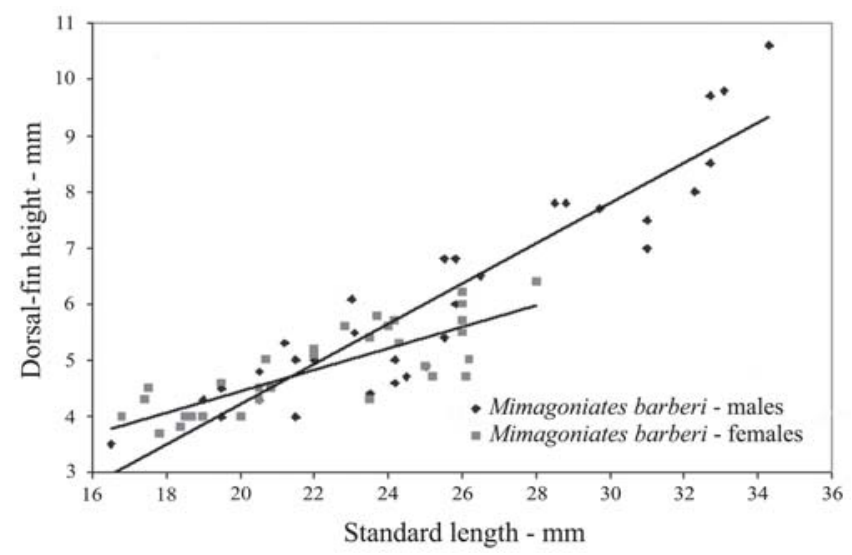

Fig 43. Mimagoniates barberi, dorsal-fin length as function of SL by sex.

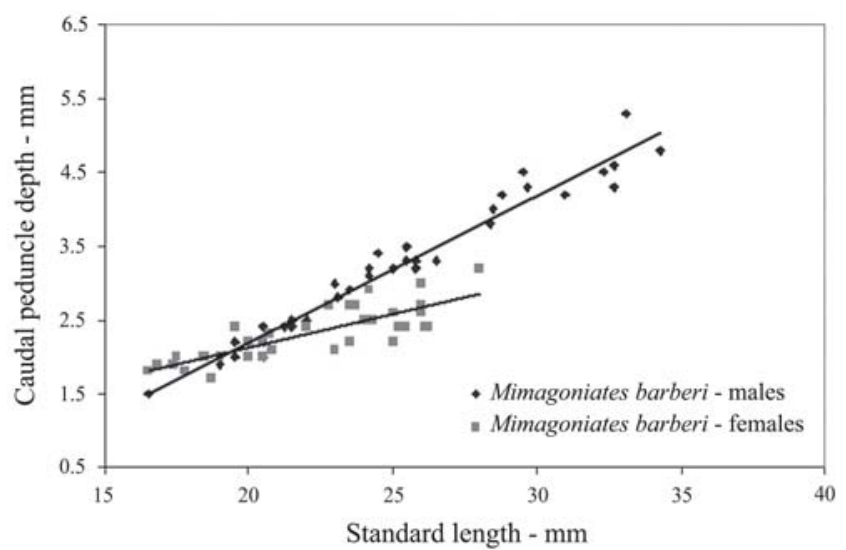

Fig. 44. Mimagoniates barberi, caudal peduncle depth as function of SL by sex.

easterly road to Captain Bado, about 233's 56³4'W; UMMZ 205417, 1 juvenile, 2 females, 17.6-25.4 mm SL, Canendiyu, small arroyo tributary to arroyo Curuguaty, about $5.3 \mathrm{~km}$ by dirt road

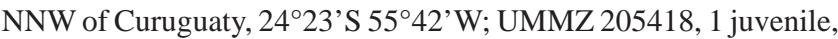
1 adult female, San Pedro/Canendiyu, río Corrientes and adjacent pool, about $32.4 \mathrm{~km} \mathrm{~W}$ of turnoff to Curuguaty, $24^{\circ} 19^{\prime} \mathrm{S} 55^{\circ} 59^{\prime} \mathrm{W}$; UMMZ 205415, 1 adult female, 1 adult male, 30.332 .6 mm SL, Canendiyu, río Jejui, tributary to río Jejui Guazu about 41 km N of 
Curuguaty and $2 \mathrm{~km} \mathrm{~S}$ of Ygatimi, about 2409' $55^{\circ} 37^{\prime} \mathrm{W}$; USNM 86296, 1 juvenile, SL approx. 19.0 mm, "probably Paraguay; USNM 327586, 1 adult male, $32.7 \mathrm{~mm}$ SL aquarium specimen collected "within 50 miles of Asuncion”; MHNG 2241.78, 9 juveniles-adults, 21.5-25.4 mm SL, San Pedro Province (southern Paraguay), without further locality data; MHNG 2477.61, 26 young-adults, 13.3-28.0 mm SL, Caaguazú, $15 \mathrm{~km}$ north east of Carapo (= Carayao), arroyo Hondo, approximately $25^{\circ} 01^{\prime}$ 'S $056^{\circ} 32^{\prime}$ W. MHNG 2481.90, 27 young-adults, 12.2-31.0 mm SL, Caaguazú, río Guyraugua (= Guyraunguá), approximately $25^{\circ} 15^{\prime}$ S 56º2'W; MHNG 2481.91, 3 juveniles, 17.5-20.4 mm SL, Alto Parana, río Acaray, (this river extends approximately between $25^{\circ} 32^{\prime} \mathrm{S} 54^{\circ} 36^{\prime} \mathrm{W}$ and $24^{\circ} 58^{\prime} \mathrm{S}$ $\left.55^{\circ} 20^{\prime} W\right)$, C. Dlouhy, 16 Oct. 1986.

\section{Mimagoniates pulcher, new species Figs. 45-46}

Mimagoniates sp. Menezes, 2007: 38 (listed). - Menezes et al., 2008: 33, 38, 41, 43 (discussion of relationships).

Mimagoniates sp. n. Menezes et al., 2008: 39, 40 (distribution; discussion of biogeography).

Holotype. MNRJ 17814, developing male, 35.0 mm SL, Brazil, Mato Grosso, "Porto Velho-São Luiz de Cáceres”, 1934, Avelar.
Paratypes. Following lot of immatures to adults collected with holotype: MNRJ 4233, 28, 17.8-37.0 mm SL.

Diagnosis. Mimagoniates pulcher is apparently most similar to $M$. barberi and $M$. inequalis with respect to the modification of caudal-fin rays in association with caudal pump, but differs at once from these two species in having hooks on caudal-fin rays at least in adult male specimens (compare Fig. 47 with Figs. 32 and 38). Additionally, from $M$. barberi it is distinguished in having anal-fin rays 26-30 (3136 for $M$. barberi) and from $M$. inequalis in having 43-46 lateral series scales (34-41 for $M$. inequalis). Mature males of the remaining species of Mimagoniates have principal caudalfin rays modified to form a fully developed caudal-fin ray pump (Figs. 58, 67, 72, and 80).

Description. Table 8 presents morphometrics of holotype and paratypes. The entire description refers to the single population sample available representing the types.

Body compressed, relatively elongate; body deepest at vertical line through pelvic-fin origin. Predorsal profile of body gently convex in all specimens, Body profile slightly elevated at dorsal-fin origin. Dorsal profile of body nearly straight along dorsal-fin base to adipose fin. Body profile posterior to adipose fin slightly concave dorsal to caudal

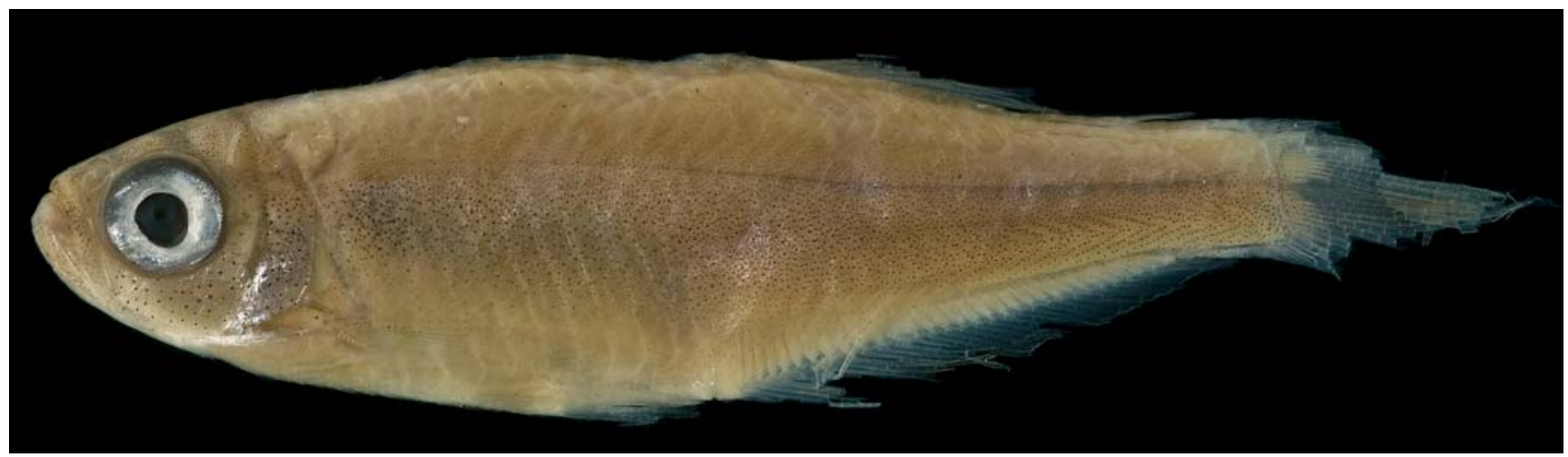

Fig. 45. Mimagoniates pulcher, male, MNRJ 17814, SL 35.0 mm SL, Brazil, Mato Grosso, "Porto Velho-São Luís de Cáceres”, holotype.

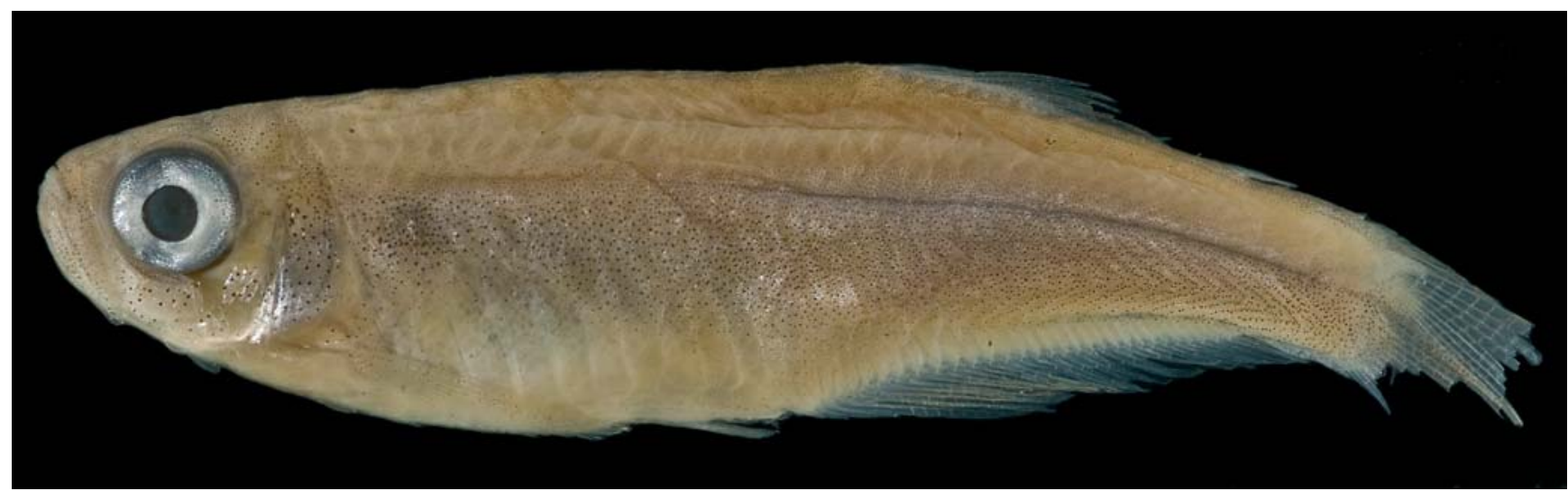

Fig. 46. Mimagoniates pulcher, female, MNRJ 4233, SL 26.3 mm SL, Brazil, Mato Grosso, “Porto Velho-São Luís de Cáceres”, paratype. 
peduncle. Dorsal-fin origin nearer to caudal-fin base than to snout tip. Ventral profile of body convex in developing males from tip of lower jaw to origin of pelvic fins, less strongly convex in females and juveniles. Abdominal profile in adult males slightly concave to anal-fin origin, straight or nearly so in females and juveniles. Body profile along anal-fin base in males slightly concave along base of anterior lobe of anal fin; straight along base of remainder of fin in males and along entire anal-fin base in females and juveniles. Ventral profile of caudal peduncle slightly convex in developing males; slightly concave or nearly straight in females and juveniles.

Lower jaw protruding, slightly beyond upper jaw. Lower jaw of developing males and females somewhat thick and heavy compared to that of juveniles. Mouth angled posteroventrally. Maxilla long, extending to point slightly ventral to a horizontal line drawn from ventral border of eye in all specimens. Maxilla extends posteriorly to a point slightly posterior to vertical through anterior border of eye.

Dorsal-fin unbranched rays ii in all specimens, branched rays 7-8 (8), 8.0, $\mathrm{n}=29$; posterior ray not split to its base and counted as 1 ray. Anal-fin unbranched rays iv in all specimens, branched rays 26-30 (29), 28.4, $n=28$; posterior ray split to its base and counted as 1 ray. Anal fin with weakly developed lobe anteriorly (Figs. 45, 46 and 50). Lobe includes last unbranched ray and first 4 branched rays. Anal fin of developing males with bilateral hooks, 1 rudimentary hook on fourth, through seventh branched rays in specimen MNRJ 4233, $37.0 \mathrm{~mm}$ SL (Fig. 50). Pectoral-fin unbranched ray i in all specimens, branched rays range 9-11 (9), 9.8, $n=29$. Posterior tip of pectoral fin extends posteriorly to origin of pelvic fins. Pelvic-fin rays 7 in all specimens (Fig. 49). Sexually mature, large adult developing males with over 35 hooks on each pelvic fin distributed as shown in Fig. 49.

Principal caudal-fin ray count 10/9 in all specimens, $n=$ 29. Fin rays modified in association with caudal pheromone pump as shown in Fig. 47. Caudal-fin rays without bony hooks in developing males, SL 25.0-35.0 mm, but with small hooks present on caudal-fin rays 9 and 10 in a larger apparently mature male, SL $37.0 \mathrm{~mm}$ (Figs. 47 and 48).

Scales cycloid, with more radii along posterior border, including terminal scale of modified caudal-fin series than in any other Mimagoniates species (Fig. 48).

Lateral line incomplete, perforated scales 7-8 (7), $n=8$. Lateral series scales $=43-46(43), 44.6, n=8$. Predorsal scales 20-22 (22), 21.1, $n=8$. Scale rows between dorsal-fin and analfin origins 13-15 (14), 13.8, $n=4$. Scale rows around caudal peduncle 16 in 4 specimens.

Premaxillary teeth in 2 irregular, almost undistinguishable, closely packed rows. Teeth count on left premaxilla given as total (Fig. 51). Larger and smaller teeth tricuspid in all large specimens, small teeth in smaller specimens sometimes bicuspid or conical. Total premaxillary teeth 7-10 (9), 8.7, n = 29. Maxillary teeth 2-6 (5), 3.6, larger specimens usually with higher counts, $\mathrm{n}=28$. All maxillary teeth (Fig. 51) tricuspid in large specimens; small specimens with posterior maxillary teeth often conical. Dentary with 4 large anterior tricuspid teeth in all specimens, smaller posterior teeth 6-10 (7), 7.2, number of teeth nearly always greater in largest specimens; anterior teeth tricuspid, posterior ones conic, $n=28$. See

Table 8. Morphometrics of Mimagoniates pulcher. Standard length is expressed in mm; measurements through bony head length are percentages of standard length; the last four entries are percentages head length. A plus sign under the abbreviation dif indicates there is a significant statistical difference between the males and females in the particular character indicated. Those receiving a plus sign and an asterisk are probably not significant. Specimens are from "Porto Velho-São Luiz de Cáceres, Mato Grosso, Brazil, MNRJ 4233. SD = Standard deviation.

\begin{tabular}{|c|c|c|c|c|c|c|c|c|c|c|}
\hline \multirow{2}{*}{ Characters } & \multicolumn{5}{|c|}{ Males } & \multicolumn{4}{|c|}{ Females and juveniles } & \multirow[b]{2}{*}{ dif. } \\
\hline & Holotype & $\mathrm{N}$ & Range & Mean & SD & $\mathrm{N}$ & Range & Mean & SD & \\
\hline Standard length & 35.0 & 06 & $25.0-37.0$ & 32.6 & & 23 & $17.8-27.0$ & 22.0 & & \\
\hline Depth at dorsal-fin origin & 26.3 & 06 & $24.0-26.2$ & 24.9 & 1.9 & 23 & $18.3-24.7$ & 21.5 & 1.7 & + \\
\hline Snout to dorsal-fin origin & 61.7 & 06 & $59.4-64.0$ & 61.5 & 1.5 & 23 & $59.8-65.7$ & 61.8 & 1.5 & - \\
\hline Snout to pectoral-fin origin & 25.1 & 06 & 24.6-26.4 & 25.4 & 0.6 & 23 & $24.7-28.0$ & 25.9 & 0.9 & - \\
\hline Snout to pelvic-fin origin & 44.6 & 06 & $40.6-48.0$ & 44.2 & 2.3 & 18 & $40.0-48.3$ & 44.4 & 2.0 & - \\
\hline Snout to anal-fin origin & 58.0 & 06 & $52.5-60.0$ & 56.6 & 2.5 & 22 & $53.3-62.8$ & 57.5 & 1.9 & - \\
\hline Caudal peduncle depth & 13.1 & 06 & 10.8-13.1 & 12.1 & 0.8 & 23 & 07.7-09.7 & 09.5 & 0.8 & + \\
\hline Caudal peduncle length & 08.3 & 06 & $07.2-08.7$ & 08.2 & 0.5 & 20 & $06.5-08.3$ & 07.2 & 0.5 & $+*$ \\
\hline Pectoral-fin length & 20.0 & 06 & $20.0-24.4$ & 22.0 & 1.4 & 23 & 20.8-24.7 & 22.6 & 1.3 & - \\
\hline Pelvic-fin length & 12.6 & 06 & $12.5-13.6$ & 13.1 & 0.4 & 23 & 10.5-13.6 & 12.4 & 0.8 & $+*$ \\
\hline Dorsal-fin base length & 13.4 & 06 & $11.6-13.4$ & 12.5 & 0.7 & 22 & $10.2-13.6$ & 12.1 & 1.1 & - \\
\hline Dorsal-fin height & 26.0 & 06 & $24.0-27.8$ & 26.1 & 1.4 & 20 & 21.6-26.9 & 23.5 & 1.3 & + \\
\hline Anal-fin base length & 35.6 & 06 & $32.7-41.0$ & 35.8 & 2.8 & 21 & $34.6-42.3$ & 37.7 & 1.9 & $+*$ \\
\hline Anal-fin lobe length & 20.0 & 06 & $16.9-21.6$ & 19.6 & 1.5 & 21 & $16.8-25.5$ & 21.6 & 2.1 & $+*$ \\
\hline Eye to dorsal-fin origin & 49.1 & 06 & $48.0-52.0$ & 49.1 & 1.6 & 23 & $45.8-51.6$ & 48.1 & 1.5 & - \\
\hline Dorsal-fin origin to caudal-fin base & 42.3 & 06 & $40.2-42.3$ & 41.2 & 0.8 & 23 & $36.2-42.0$ & 38.8 & 1.4 & $+*$ \\
\hline Bony head length & 24.3 & 06 & 23.4-26.0 & 24.7 & 0.9 & 22 & $24.0-27.3$ & 25.4 & 0.7 & - \\
\hline Horizontal eye diameter & 35.3 & 06 & $34.4-38.4$ & 36.2 & 1.5 & 22 & $37.0-42.5$ & 39.1 & 1.5 & $+*$ \\
\hline Snout length & 22.5 & 06 & $20.2-22.5$ & 21.5 & 0.8 & 22 & $18.1-22.2$ & 20.5 & 1.2 & - \\
\hline Least interorbital width & 34.1 & 06 & $34.1-36.1$ & 35.0 & 0.7 & 22 & $33.3-37.0$ & 35.2 & 1.2 & - \\
\hline Upper jaw length & 41.2 & 06 & $41.1-47.5$ & 43.8 & 2.4 & 22 & $40.0-46.3$ & 43.1 & 1.8 & - \\
\hline
\end{tabular}


Fig. 51. Maxillary and dentary teeth shaped much like premaxillary teeth.

Vertebrae 37-40 (38), 38.4, $\mathrm{n}=28$. Dorsal limb gillrakers 67 (6), 6.03, $n=28$; ventral limb gill rakers 11-13 (12), 11.8, $n=$ 28. Branchiostegal rays 3 , in 1 cleared and stained specimen, 3 rays originating on anterior ceratohyal and 1 ray from posterior ceratohyal.

Color in alcohol. Description based on specimens kept in alcohol since 1939 so that it likely reflects only vestiges of original coloration. See Figs. 45 and 46 for preserved color

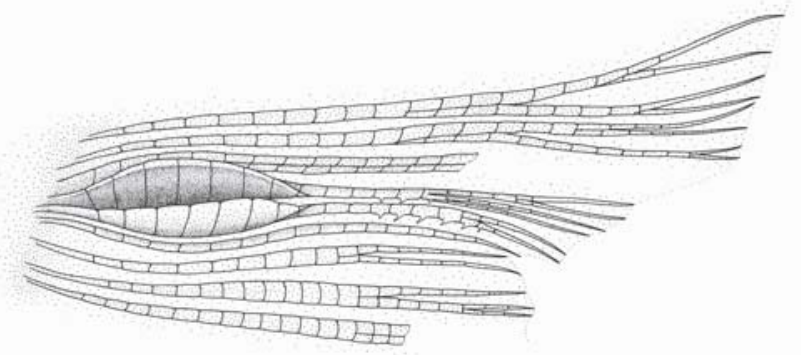

Fig. 47. Mimagoniates pulcher, developing male, MNRJ 4233, $34.2 \mathrm{~mm}$ SL; osteology of principal caudal rays 7-15, lateral view, left side, anterior at right. pattern of males and females. Body pale brown, slightly lighter ventrally. Scattered dark chromatophores all over body, more heavily concentrated laterally and extending onto middle caudal-fin rays, indicating what could have been diffuse stripe, more evident in males than in females. Dark line slightly above midbody from about vertical crossing pelvic-fin origin

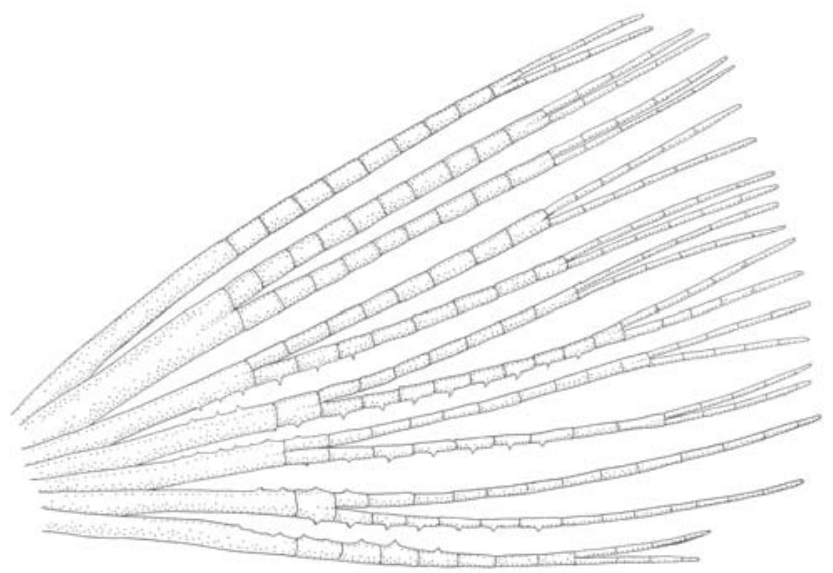

Fig. 49. Mimagoniates pulcher, developing male, MNRJ 4233, $37.0 \mathrm{~mm}$ SL; pelvic-fin rays, ventral view, left side.

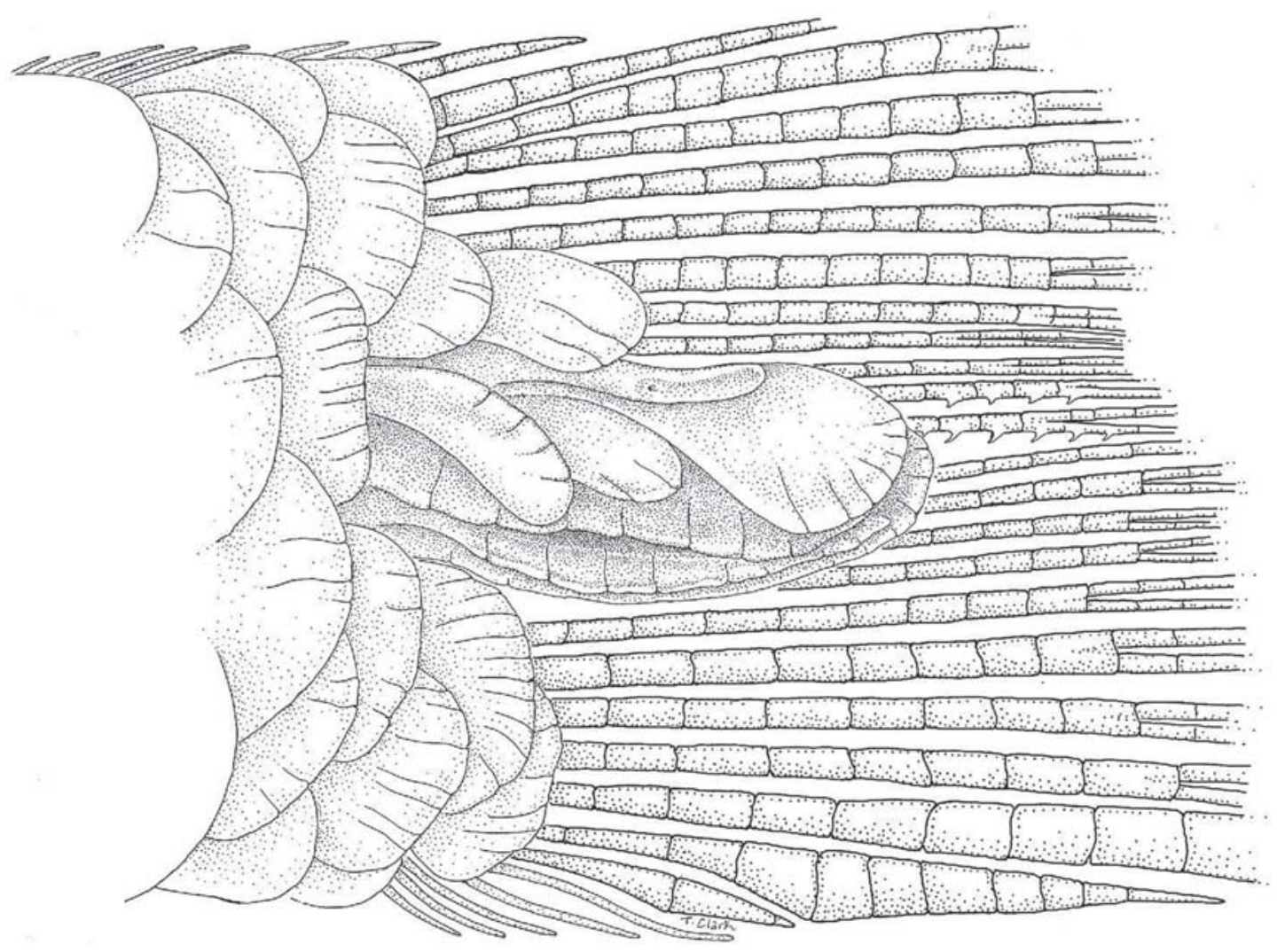

Fig. 48. Mimagoniates pulcher, male, MNRJ 4233, $43.2 \mathrm{~mm}$ SL; caudal-fin squamation of dorsal and ventral portions of caudalfin lobe. 
to caudal peduncle.

Pectoral, pelvic, dorsal, and anal fins with scattered dark chromatophores along fin rays and membranes. Anal fin with dark, elongate stripe running length of fin; stripe wider and more conspicuous anteriorly in both sexes. Dorsal-fin with diffuse horizontal dark stripe in developing males and females extending posteriorly from about mid-length of anterior elongate undivided ray to posterior tips of two terminal dorsalfin rays. Adipose fin dusky with scattered dark chromatophores.

Head brown overall with scattered dark chromatophores, those on infraorbitals below eye and opercular bones slightly darker than those along midbody. Iris silvery. Circumorbitals pale yellowish brown.

Sexual dimorphism. Fully mature males and females are not represented in available sample. The largest developing male (37.0 mm SL) has a caudal pheromone organ and anal and pelvic-fin hooks (Figs. 47 to 50) but the largest developing female (26.3 mm SL) lacks the caudal organ and fin hooks of males. Table 7 indicates that body depth, caudal peduncle depth and dorsal-fin height might be sexually dimorphic and tend to be greater in males than in females.

Distribution. The only available sample of Mimagoniates pulcher originated from an uncertain locality in the upper rio Paraguai in Mato Grosso, Brazil (see notes on the type locality). See fig. 3 in Menezes et al. (2008).

Etymology. The name pulcher is from the Latin meaning beautiful and refers to the usual blue color of the species of Mimagoniates when alive.

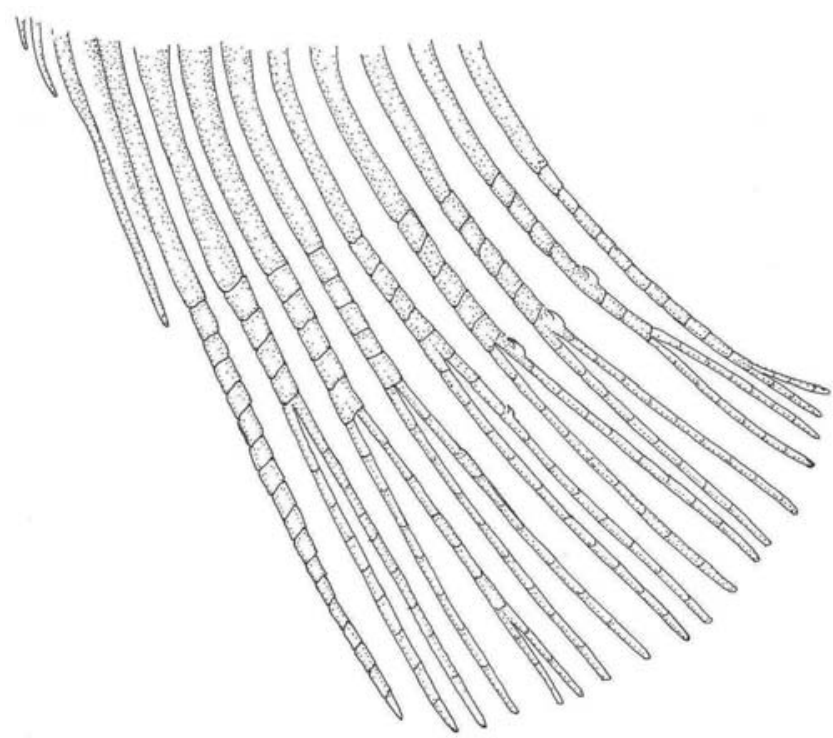

Fig. 50. Mimagoniates pulcher, developing male, MNRJ 4233, $37.0 \mathrm{~mm}$ SL; anterior 13 anal-fin rays, lateral view, left side.

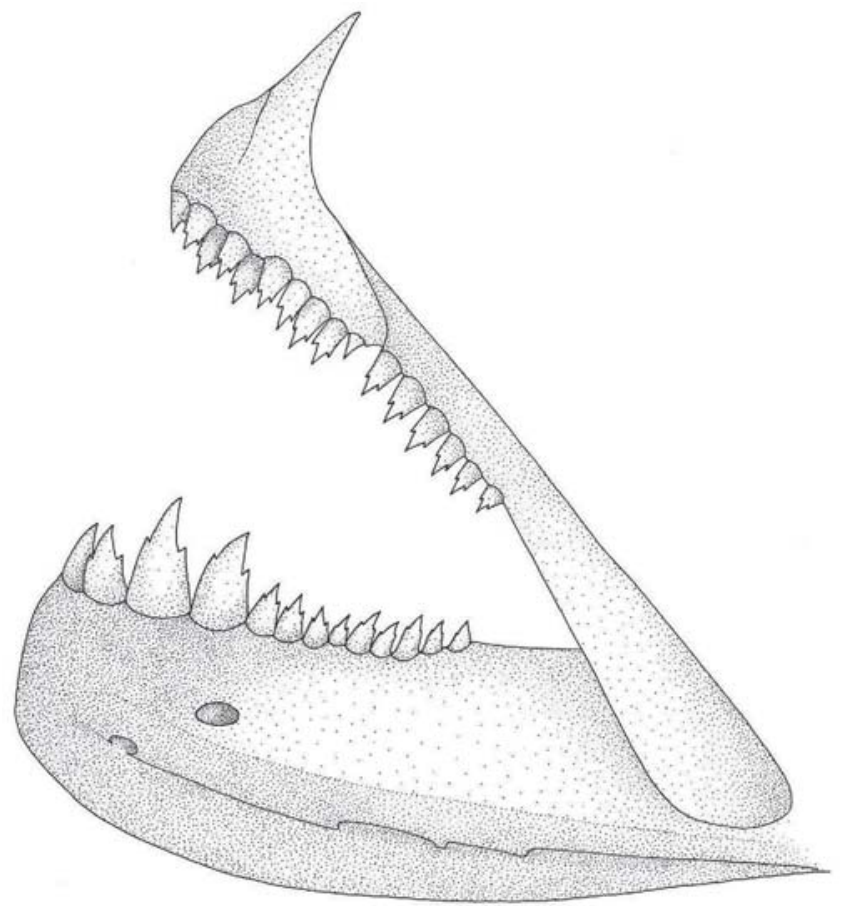

Fig. 51. Mimagoniates pulcher, developing male, MNRJ 4233, $34.2 \mathrm{~mm} \mathrm{SL}$; jaws and dentition, lateral view, right side, anterior at left.

Notes on type locality. The type locality for M. pulcher is vague and one of us (Menezes) was unable to locate this species on two collecting trips to the area around Cáceres (= São Luiz de Cáceres in 1934) in 1991 and 1992. At first we assumed that "Porto Velho-São Luiz de Cáceres" implied that this lot was collected somewhere between Cáceres, Mato Grosso State and Porto Velho, Rondônia State, a straight line distance of a little over $600 \mathrm{~km}$. Examination of an American Geographical Society of New York map: Cuyabá for 1930, revealed another Porto Velho, this time in Mato Grosso on the upper part of the rio Arinos, a tributary of the rio Juruena into the rio Tapajós of the Amazon basin. The map shows this Porto Velho as a head water stopping point for river traffic with a trail leading south to Cuiabá and then to Cáceres. A collecting trip to this area and southward yielded no specimens of Mimagoniates. The area is now partly under soy bean culture and no typically black waters were found. Alteration of the habitat may have changed the nature of the streams of the area. Mimagoniates pulcher, if it was originally found in this region, may be extinct.

Remarks. The structure of the caudal organ of Mimagoniates pulcher is more similar to that of $M$. barberi than to any other species of Mimagoniates (compare Fig. 47 to Fig. 38). Since Fig. 47 is based on a developing male it might be possible that in mature males the caudal organ is more developed and attains a modified structure. 
Mimagoniates lateralis (Nichols, 1913) Figs. 52-55

Coelurichthys lateralis Nichols, 1913: 151 (type locality: none, "These two small aquarium fishes were presented to the American Museum of Natural History by Mr. William Mack, of New York. There was no accompanying data, but they are probably South American, and are referred to the genus Coelurichthys of Ribeiro”). - Nelson, 1964a: 65 (found female type of $C$. lateralis difficult to identify and could not decide whether it was $C$. microlepis or same as C. tenuis, but if it were latter, C. lateralis would have priority because of page precedence).

Coelurichthys tenuis Nichols, 1913: 152 (type locality: none, same remarks as above under M. lateralis). - Schultz, 1959: 63, (erroneously referred to M. inequalis). - Nelson, 1964a: 62, 127 (considered male holotype valid species distinct from M. microlepis). - Géry, 1966: 320 (questioned whether M. tenuis is synonym of M. lateralis). - Géry, 1977: 362 (listed and noted that $M$. barberi of aquarists is apparently C. tenuis). - Sterba, 1987: 69 (aquarium description).

Mimagoniates barberi (not of Regan, 1907: 402), Rachow,
1927: 17 (misidentification of M. lateralis for M. barberi). Myers, 1928: 120 (misidentification). Rachow, 1928: 15 (misidentification). - Holly et al., 1950: 779, (misidentification; list of aquarium and ichthyological literature mostly referring to M. lateralis prior to 1941).

Mimagoniates inequalis Schultz, 1959: 11, 63 (in part, misidentified specimens of $M$. lateralis, USNM 94117, as M. inequalis).

Mimagoniates lateralis Weitzman \& Fink, 1985: 106, 109 (in list of material examined). - Weitzman et al., 1988: 404 (caudal skeleton, gland and entire specimens illustrated; discussion of phylogeny and biogeography). - Menezes \& Weitzman, 1990: 385 (in key to species of Glandulocaudini). - Machado et al., 2005: 73 (conservation status). - Guimarães et al., 1995: 185-189 (cytogenetic studies). - Weitzman et al., 1996a: 206, 209 (distribution; courtship behavior). Weitzman, 2003: 226 (maximum length; distribution; remarks and references). - Menezes et al., 2007 (photograph; distribution; systematic status; synonyms; ecology and conservation status). - Menezes, 2007: 39 (listed in catalog; distribution; conservation status). - Menezes et al., 2008: 38-40 (distribution; discussion of relationships and
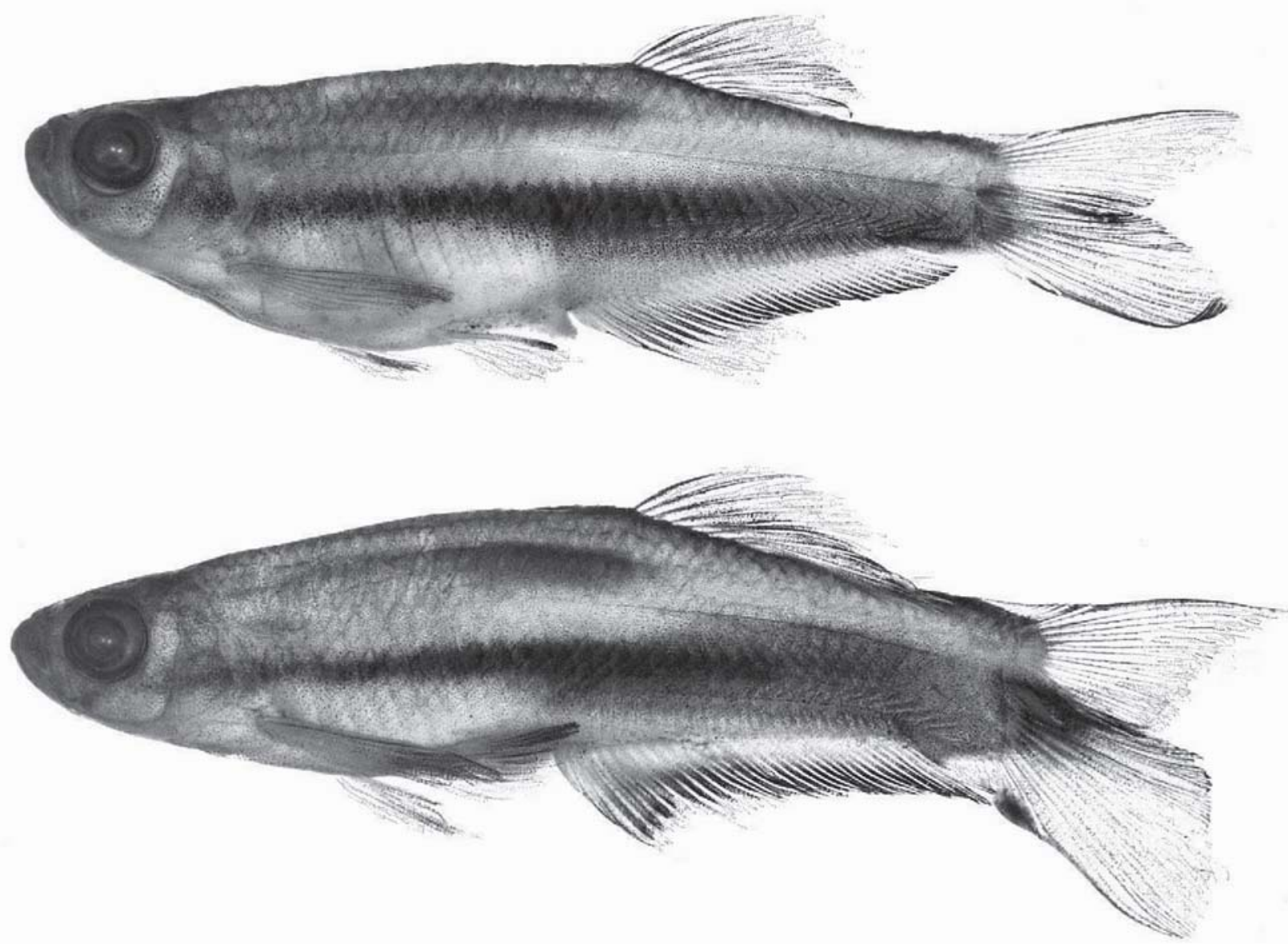

Fig. 52. Mimagoniates lateralis, young adults female above, male below. USNM 226468, 31.0 and 32.6 mm SL respectively, Paraná State, road between Paranaguá and Matinhos, at km 11. 


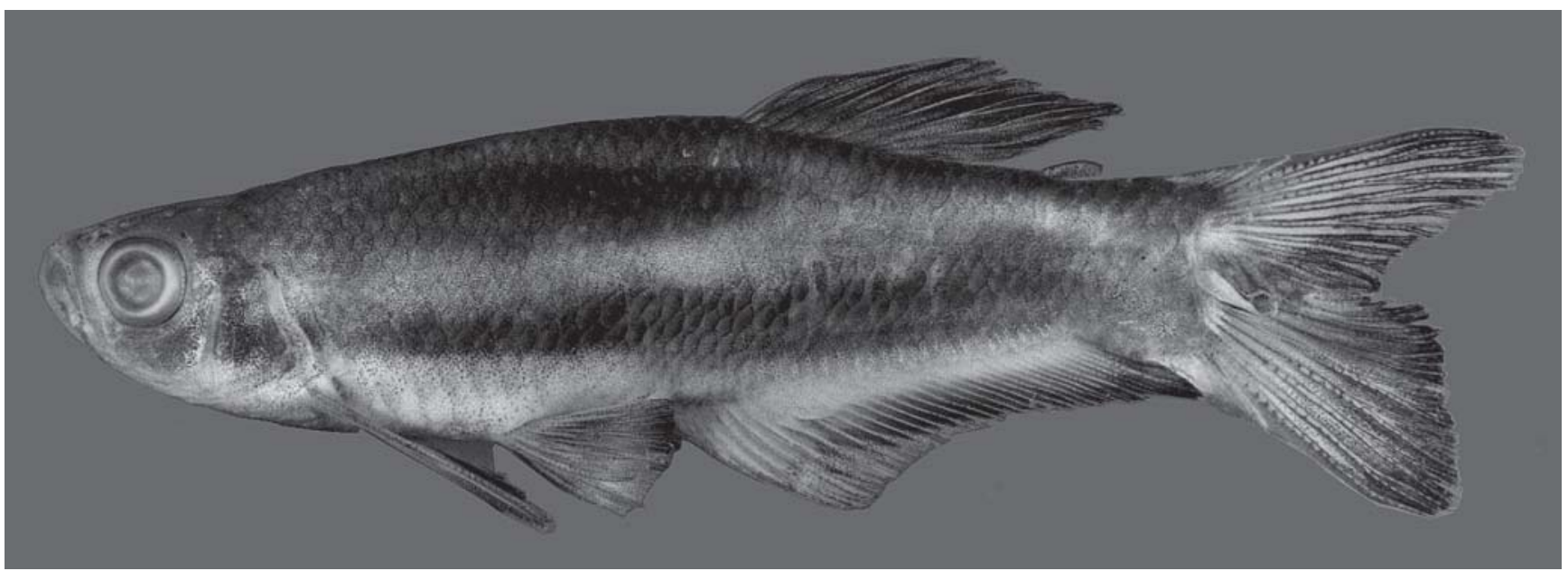

Fig. 53. Mimagoniates lateralis, live adult male, USNM 254268, 29.9 mm SL, Brazil, Paraná State, unnamed blackwater stream emptying into Atlantic Ocean about 5 km S of Guaratuba.

biogeography). - Duboc \& Menezes, 2008: 77 (conservation status; general informations; geographic distribution; main threats; conservation strategies).

Diagnosis. Mimagoniates lateralis and M. sylvicola are the only species of the genus having a caudal fin-ray pump well developed and no hooks on caudal-fin rays (Figs. 58 and 67). M. lateralis, however, has fewer lateral series scales (35 to 41 vs. 49 to 56 for M. sylvicola), fewer horizontal scale rows from dorsal-fin origin to anal-fin origin (13 to $15 v s$. 16 to 18 for $M$. sylvicola), and fewer scale rows around caudal peduncle (16 to 18 vs. 19 to 20 for M. sylvicola). Color differences between the two species are discussed in the diagnosis of M. sylvicola. Mimagoniates rheocharis and M. microlepis also with a fully developed caudal-fin ray pump in mature males, have hooks on principal caudal-fin rays (Figs. 75 and 85), absent in M. lateralis and M. inequalis; M. barberi and M. pulcher has a rudimentary caudal-fin ray pump (Figs. 32, 38 and 47).

Description. Table 9 presents morphometrics of the holotype and the population sample from Cananéia, São Paulo. The entire description refers to this population sample which includes a large series from immature to fully mature male and

Table 9. Morphometrics of Mimagoniates lateralis. Standard length is expressed in mm; measurements through head are percentages of standard length; the last four entries are percentages head length. A plus sign under the abbreviation dif. indicates a significant difference between the males and females in the particular character indicated. Specimens are from a stream near town of Cananéia, São Paulo, USNM 326250 and an unknown locality in South America, AMNH 4072 and AMNH 4087. SD = Standard deviation.

\begin{tabular}{|c|c|c|c|c|c|c|c|c|c|c|}
\hline \multirow{2}{*}{ Characters } & \multicolumn{4}{|c|}{ Males } & \multicolumn{5}{|c|}{ Females and juveniles } & \multirow[b]{2}{*}{ dif. } \\
\hline & $\mathrm{N}$ & Range & Mean & SD & Holotype & $\mathrm{N}$ & Range & Mean & SD & \\
\hline Standard length & 23 & $17.0-31.0$ & 25.6 & & 29.6 & 29 & $16.9-36.2$ & 26.5 & & \\
\hline Depth at dorsal-fin origin & 23 & $20.6-28.6$ & 24.5 & 2.2 & 27.4 & 29 & $20.7-27.4$ & 24.6 & 1.8 & - \\
\hline Snout to dorsal-fin origin & 23 & $58.8-63.5$ & 61.6 & 1.1 & 59.5 & 29 & $59.1-65.5$ & 61.8 & 1.5 & - \\
\hline Snout to pectoral-fin origin & 23 & $24.5-27.6$ & 26.0 & 1.0 & 25.0 & 29 & $24.7-27.7$ & 25.8 & 0.9 & - \\
\hline Snout to pelvic-fin origin & 23 & $41.0-45.0$ & 43.0 & 1.0 & 42.6 & 29 & $40.2-45.3$ & 43.6 & 1.2 & - \\
\hline Snout to anal-fin origin & 23 & $54.2-58.8$ & 56.8 & 1.2 & 56.8 & 29 & $55.0-60.4$ & 58.0 & 1.2 & - \\
\hline Caudal peduncle depth & 23 & $10.5-15.2$ & 12.9 & 1.3 & 13.9 & 29 & 08.9-14.6 & 11.9 & 1.1 & + \\
\hline Caudal peduncle length & 23 & 08.1-10.4 & 09.0 & 0.5 & 09.5 & 29 & 07.9-09.9 & 08.7 & 0.5 & - \\
\hline Pectoral-fin length & 23 & $21.0-25.3$ & 23.6 & 1.1 & 22.0 & 29 & $21.3-25.3$ & 23.4 & 1.2 & - \\
\hline Pelvic-fin length & 23 & $13.7-17.8$ & 15.5 & 1.3 & 14.2 & 29 & $12.6-15.5$ & 14.3 & 0.6 & + \\
\hline Dorsal-fin base length & 23 & $12.0-15.0$ & 13.3 & 0.8 & 11.8 & 29 & 11.6-14.1 & 12.6 & 0.6 & - \\
\hline Dorsal-fin height & 23 & 20.4-29.3 & 24.0 & 2.3 & 22.0 & 29 & 20.1-24.2 & 22.2 & 0.9 & - \\
\hline Anal-fin base length & 23 & $33.6-37.4$ & 35.4 & 1.0 & 37.2 & 29 & 32.8-37.1 & 34.6 & 1.2 & - \\
\hline Anal-fin lobe length & 22 & $19.0-23.1$ & 21.7 & 0.9 & ---- & 28 & $18.9-24.4$ & 21.3 & 1.0 & - \\
\hline Eye to dorsal-fin origin & 23 & 47.6-51.8 & 49.3 & 1.1 & 46.6 & 29 & 46.1-51.4 & 49.1 & 1.2 & - \\
\hline Dorsal-fin origin to caudal-fin base & 23 & 37.3-43.1 & 40.5 & 1.5 & 41.8 & 29 & $37.2-41.3$ & 39.4 & 1.2 & - \\
\hline Bony head length & 23 & 23.8-27.3 & 25.2 & 1.0 & 23.6 & 29 & $23.6-27.0$ & 25.2 & 1.0 & - \\
\hline Horizontal eye diameter & 23 & $34.2-41.6$ & 38.2 & 2.3 & 37.7 & 29 & $35.5-41.6$ & 38.1 & 1.7 & - \\
\hline Snout length & 23 & $20.0-25.0$ & 22.0 & 1.3 & 24.3 & 29 & $20.0-24.3$ & 21.4 & 1.1 & - \\
\hline Least interorbital width & 23 & 31.9-37.0 & 34.0 & 1.3 & 37.1 & 29 & 31.2-37.1 & 34.7 & 1.3 & - \\
\hline Upper jaw length & 23 & $38.4-46.0$ & 42.9 & 2.0 & 42.9 & 29 & $38.6-47.0$ & 42.6 & 2.2 & - \\
\hline
\end{tabular}




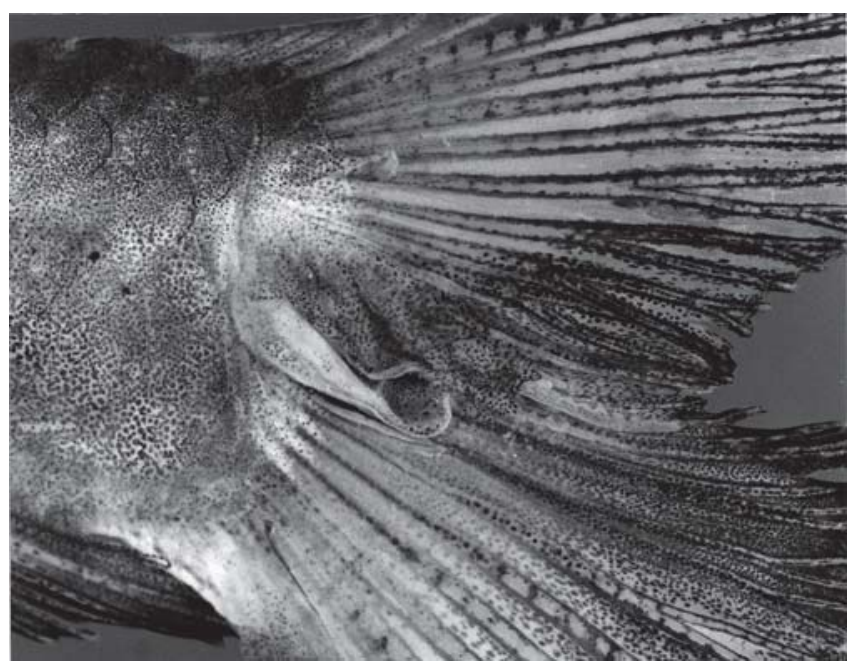

Fig. 54. Mimagoniates lateralis, adult male, USNM 254268, $34.1 \mathrm{~mm}$ SL; caudal fin and peduncle.Caudal organ in life is partly translucent and partly covered with black chromatophores. Posterior opening of caudal organ is clearly visible.

female specimens and contains the ranges of meristic and morphometric variation in within the distributional area of Mimagoniates lateralis. Counts and ratios of measurements for other population samples taken from other areas are given only when they differ from those of Cananéia.

Body compressed, moderately elongate; body deepest about midway between snout tip and dorsal-fin origin near vertical through pelvic-fin origin. Predorsal body profile strongly arched in adult males, less so in adult females and immatures which have predorsal profile gently convex. Body profile elevated at dorsal-fin origin, in males, less so in females and juveniles. Dorsal profile of body nearly straight along dorsal-fin base to adipose fin in males, slightly concave in females. Body profile posterior to adipose fin somewhat concave dorsal to caudal peduncle. Dorsal-fin origin nearer to caudal-fin base than to snout tip. Ventral profile of body convex in adult males from tip of lower jaw to origin of pelvic fin, less strongly convex in females and juveniles. Abdominal profile in adult males slightly concave to anal-fin origin, straight or nearly so in females and juveniles. Body profile along anal-fin base in males slightly concave in region of anterior lobe of anal fin; straight along base of remainder of fin in males and along entire anal-fin base in females and juveniles. Ventral profile of caudal peduncle slightly convex especially in adult males; slightly concave or nearly straight in females and juveniles.

Lower jaw protruding, slightly beyond upper jaw. Lower jaw of adult males thick and heavy compared to that of females and juveniles. Mouth angled posteroventrally. Maxilla long, extending to point ventral to horizontal through ventral border of eye in all specimens. Maxilla extends posteriorly through anterior border of pupil of eye.

Dorsal-fin unbranched rays ii in all specimens, branched rays 7-8, 8 ( 1 spm with 7$), n=50$; posterior ray not split to its base and counted as 1 ray. Anal-fin unbranched rays iv or v, usually iv, branched rays 26-30 (28), 27.6, $n=50$; population sample from Paranaguá with slightly lower counts (range = $25-28$, mean $=26.6$ ); posterior ray split to its base and counted as 1 ray. Anal fin with moderately developed lobe anteriorly (Figs. 52, 53, 55 and 56). Lobe includes fourth or fifth undivided ray and first 5-6 divided rays. Anal fin of sexually mature males with bilateral blunt hooks, 1 on each side, on last unbranched ray iv or v (Fig. 56). Usually anterior 4 branched fin rays with bilateral hooks, 1 set for each ray. Pectoral-fin unbranched ray $i$ in all specimens, branched rays 7-10, 9.3, n $=50$. Posterior tip of pectoral fin extends posteriorly beyond origin of pelvic fin. Pelvic fin rays 7 in all specimens. Pelvic fin with anterior (first) ray branched in all specimens, posterior ray unbranched in most individuals (Fig. 57). Sexually mature,

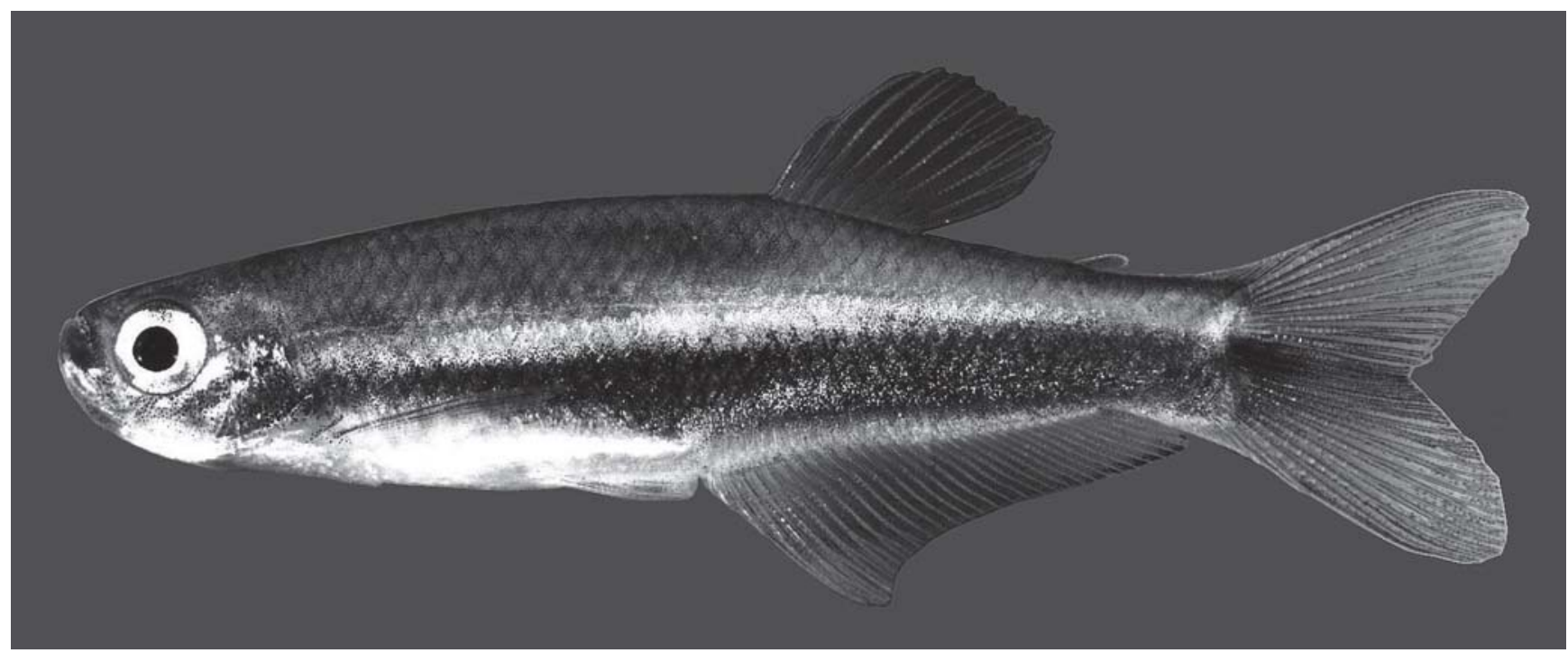

Fig. 55. Mimagoniates lateralis, live adult female, USNM 254268, 29.8 mm SL, Santa Catarina State, rio Vermelho, Barra do Sul in Ilha de São Francisco, about 35 km from Joinville. 


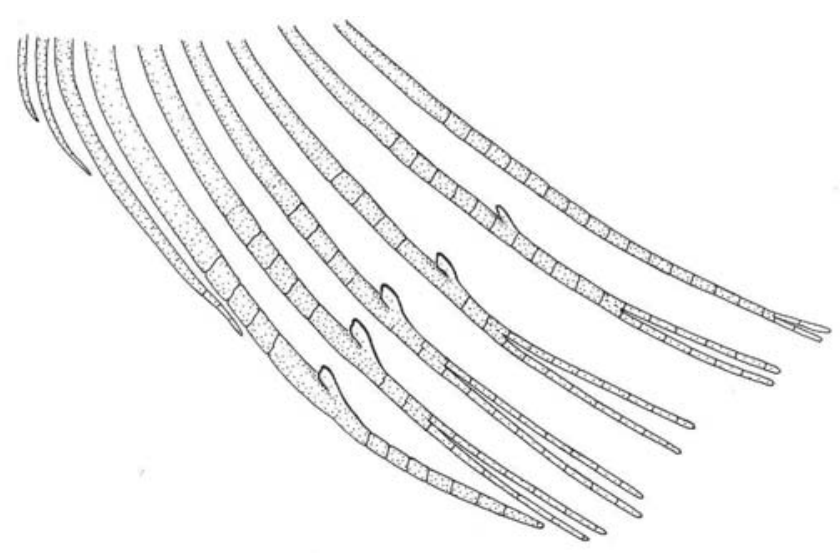

Fig. 56. Mimagoniates lateralis, adult male, USNM 236088, $31.6 \mathrm{~mm}$ SL; anterior 9 anal-fin rays of adult male, lateral view, left side.

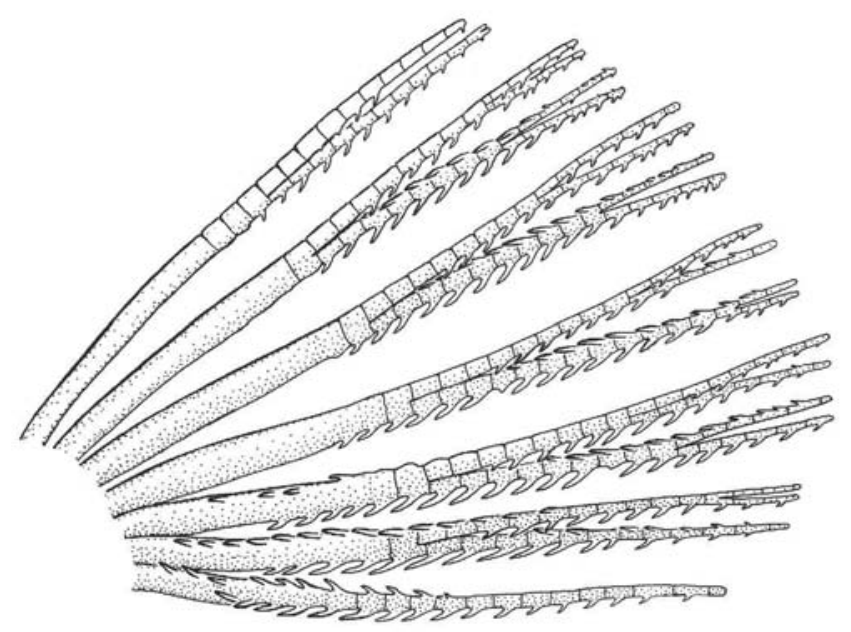

Fig. 57. Mimagoniates lateralis, adult male, USNM 236088, $31.6 \mathrm{~mm}$ SL; pelvic-fin rays, ventral view, left side.

large adult males with over 250 small to tiny hooks on each pelvic fin distributed as shown in Fig. 57.

Principal caudal-fin ray count $10 / 9, n=50$. Fin rays modified in association with caudal pheromone pump as in Fig. 58.

Scales cycloid, with few radii along posterior border. Terminal scale of modified caudal-fin series without exaggerated radii (Fig. 58).

Lateral line incomplete, perforated scales 5-7 (5), 6.1, $\mathrm{n}=33$. Lateral series scales 35-41 (41), 38.8, $n=32$. Population sample from Santa Catarina with higher counts (range $=38-42$, mean $=$ 41.1 $\mathrm{n}=53$. Predorsal scales 21-25 (no data for holotype) 22.3, $\mathrm{n}=30$. Population sample from Paranaguá with slightly higher counts (range $=23-26$, mean $=24.1, n=10$ ). Scale rows between dorsal- and anal-fin origins 13-15 (15), mean $=14.4, n=41$. Scale rows around caudal peduncle 16-18 (17), 16.7, $\mathrm{n}=28$.

Premaxillary teeth in 2 distinct rows (not clear in Fig. 59). All teeth tricuspid in all large specimens, smaller specimens with small teeth sometimes bicuspid or conical. Outer row teeth 6-9 (7), 7.0, $\mathrm{n}=50$. Inner row teeth few, 3 2-4 (3), 2.5, $\mathrm{n}=$ 50. Maxillary teeth 3-9 (6), 5.5, larger specimens usually with higher number of teeth, $n=50$. Population sample from Santa Catarina with slightly lower counts (range $=3-7,=4.3, n=53$ ). All maxillary teeth tricuspid in large specimens; small specimens with posterior maxillary teeth often conical (Fig. 59). Dentary with 4 large anterior tricuspid teeth in all specimens followed by smaller posterior teeth 5-13 (6), 8.7, number of teeth nearly almost greater in largest specimens; anterior small teeth of posterior dentary row tricuspid, posterior ones conical, $n=50$ (Fig. 59). Maxillary and dentary teeth shaped much like premaxillary teeth.

Vertebrae 37-42 (37), 39.3, $n=68$. Dorsal limb gill rakers 67 (6), 6.2, $n=50$; ventral limb gill rakers 11-13 (12), 11.8, $n=50$. Branchiostegal rays 4 in 4 cleared and stained specimens, 3 rays originating on anterior ceratohyal and 1 ray from posterior ceratohyal.

Color in alcohol. See Figs. 52, 53 and 55 for preserved color pattern of males and females. Body pale to medium brown, pale yellowish-brown ventrally, much darker dorsally. Humeral spot barely distinguishable from anterior portion of horizontal body stripe. Dark lateral body stripe clearly defined in both sexes, below midbody, narrower anteriorly from ventral border of eye to about vertical through tip of pectoral fin, wider from this point to caudal-fin base and extending onto part of caudal fin occupied by caudal organ in males and onto an equivalent area on caudal fin of females. Lateral stripe extends over all caudal gland structures, including those derived from dorsal caudalfin lobe such as modified caudal squamation. Stripe especially dark on principal ray 10 , and basal portions of rays 11,12 , and 13; less so in females. Remainder of caudal fin dusky due to scattered dark chromatophores. Dorsal border of first and ventral border of nineteenth principal caudal-fin rays black. Distal part of posterior most lower procurrent rays black. Another dark stripe dorsal to lateral stripe and separated from it by a pale area extending from dorsal border of eye to about vertical through origin of dorsal fin. This dorsal stripe narrower anteriorly, wider and darker posteriorly. Dorsal most body surface dark, forming narrow stripe extending from supraoccipital region to base of dorsal procurrent rays of caudal fin. Body surface ventral to lateral body stripe pale brown.

Pectoral, pelvic, dorsal, and anal fins dusky with scattered dark chromatophores along fin rays and membranes. Anal fin with dark elongate stripe running length of fin. Stripe width about two-thirds height of anal fin anteriorly and little more than one-half height posteriorly. Stripe narrower posteriorly, but of uniform width for posterior one-half of fin where it borders ventral edge of fin, broadens anteriorly in sexually mature males, especially dorsal to distally relatively hyaline anterior anal-fin lobe. Dorsal-fin with horizontal dark stripe in adult males and females extending posteriorly from about midlength of anterior elongate undivided ray to posterior tips of terminal two dorsal-fin rays. Stripe usually narrow, less than one-eighth maximum height of dorsal fin. Width and density of stripe variable depending on sex and sexual maturity. Males 


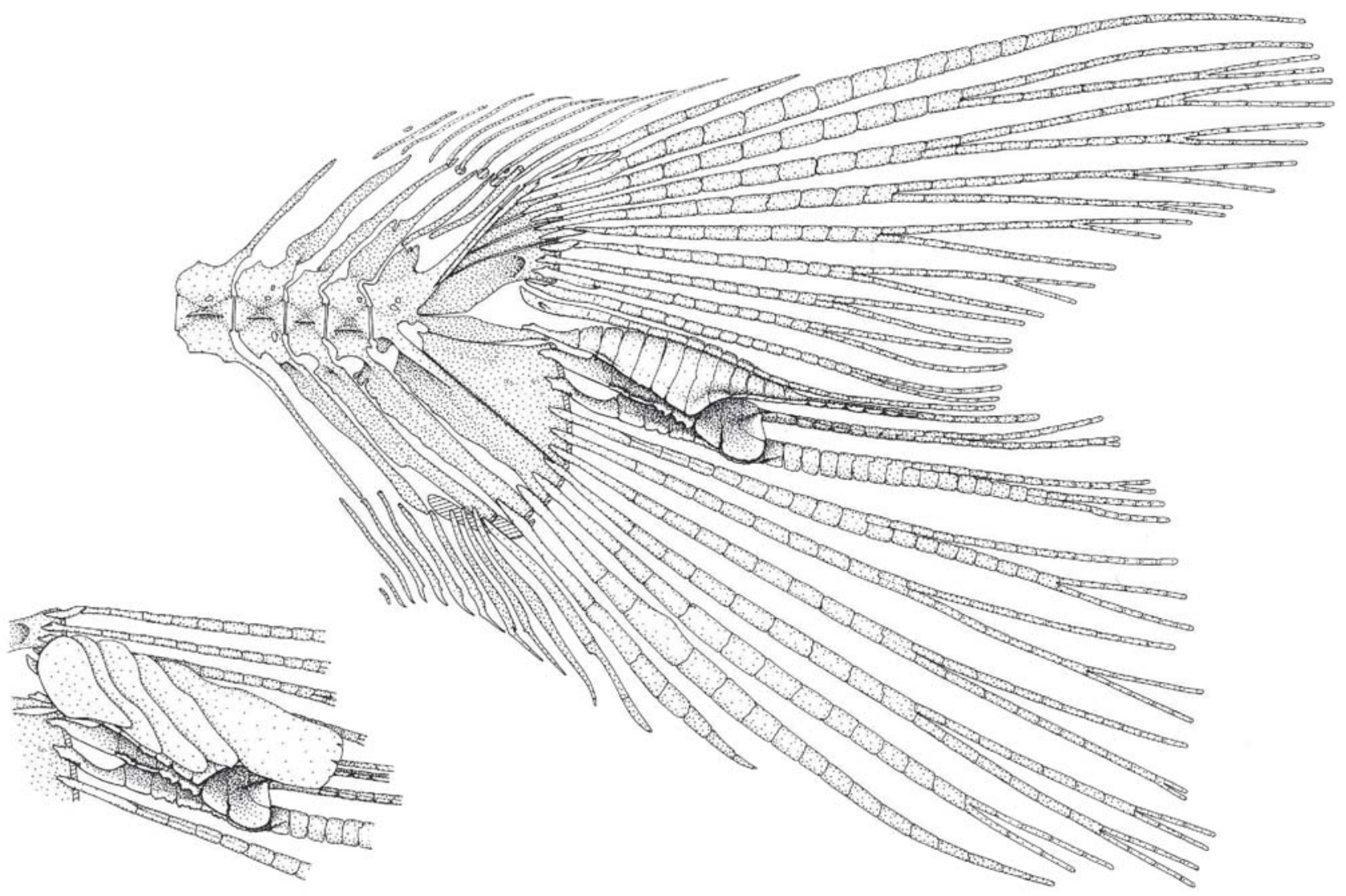

Fig. 58. Mimagoniates lateralis, adult male, USNM 236088, $31.6 \mathrm{~mm}$ SL; caudal skeleton, lateral view, left side, anterior at left. Inset at lower left illustrates modified dorsal lobe caudal-fin squamation in relation to osteological structures of caudal organ. Modified from Weitzman et al. (1988).
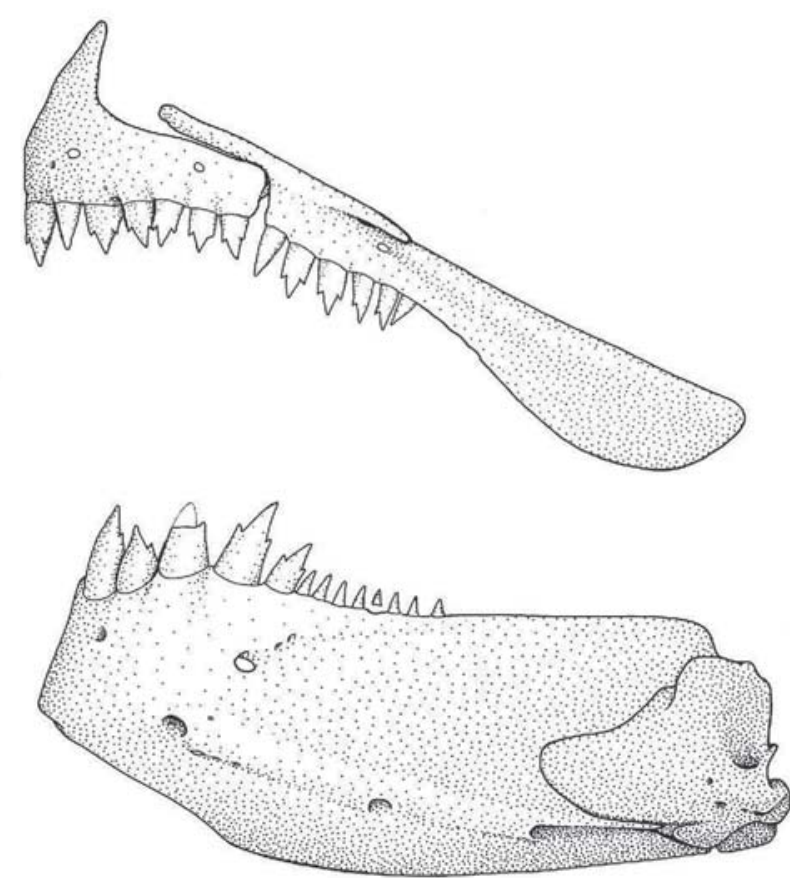

Fig. 59. Mimagoniates lateralis, adult male, USNM 236088, $31.6 \mathrm{~mm}$ SL; jaws and dentition, lateral view, right side, anterior at left. sometimes with posterior portion of stripe diffuse. Adipose fin dusky with scattered dark chromatophores.

Head dark brown around mouth and on dorsal surface of snout, between eyes, dorsal portion of cranium and nape. Tip of lower jaw dark brown. Region of head posterior to infraorbitals and extending ventrally from parietal region, across dorsal opercular region pale except where horizontal dark stripe extends to eye. Iris dorsal to pupil dark brown. Infraorbitals silvery if guanine present, pale yellowish brown if guanine absent. Dark brown chromatophores scattered evenly across circumorbital area. Anterior area of opercle, all of preopercle, and branchiostegal rays silvery or pale brown, without much dark brown pigment except in area of most inferior horizontal stripe.

Color in life. Life colors described here taken from color slides of fishes in aquarium. Sides of body pale silvery blue. Lateral stripe deep black anteriorly and obscured by blue to silvery pigment especially above anal-fin base. Dorsal part of body posterior to black stripe extending to below dorsal-fin origin brownish orange color. Longitudinal area between dorsal and lateral black stripes slivery white obscured by blue to silver pigment. Ventral opercular area, branchiostegal rays and membranes, and abdominal area silvery white. Lower jaw dark 
except for its median part with silvery blue color. Dorsal region of opercle brownish orange. Dorsal, caudal and anal fins with scattered orange red chromatophores. Dark colors of these fins as in preserved specimens. Basal portion of anal fin hyaline with some scattered orange brown chromatophores. Distal region of anterior anal-fin lobe hyaline. Males photographed just after capture with anal fin base yellow orange. Pelvic fins hyaline with scattered dark chromatophores. Pectoral fins hyaline other than for some yellow and dark chromatophores. Dorsal fin hyaline distal to longitudinal black and brown stripe, with orange brown chromatophores proximal to stripe.

Sexual dimorphism. Females lack a caudal pheromone pump organ and pelvic-fin and anal-fin hooks described above for males. Life colors of females are more subdued than that of mature males.

Among the morphometric characters having significant differences between males and females (Table 9), only caudal peduncle depth and pelvic-fin length are significantly different using regression statistics. Fig. 62 provides graphic evidence of a slight divergence in caudal peduncle depth between males and females. Fig. 61 clearly demonstrates a difference in pelvicfin length as a function of standard length between males and females as they become sexually mature and increase in length.

Distribution. Mimagoniates lateralis is restricted to small blackwater streams, rivers and ponds in the coastal area between Santos, São Paulo and Santa Catarina, Brazil. See figure 3 in Menezes et al. (2008)

Ecology. Field data indicate that Mimagoniates lateralis is entirely confined to acid black waters (Fig. 60). MZUSP 53275 (75 specimens) and USNM 326250 (66 specimens) were collected from a black water stream near Cananéia, São Paulo, running in a disturbed stretch of Mata Atlântica. The stream was on the average $1.7 \mathrm{~m}$ wide and 0.4 deep and the fishes

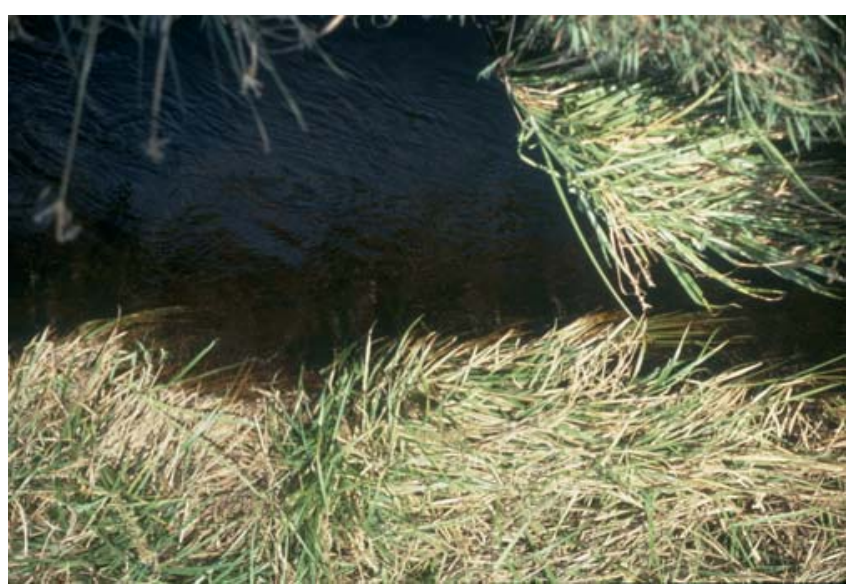

Fig. 60. Habitat of Mimagoniates lateralis, blackwater stream, rio Vermelho, in Barra dos Sul, Ilha de São Francisco, Santa Catarina State, Brazil. occurred in both sunlight or shaded areas over sandy-rocky bottoms covered with filamentous algae and dead leaves.

Remarks. Myers, in Eigenmann \& Myers (1929: 492) examined the type of Mimagoniates lateralis AMNH 4072, and identified it as a female M. microlepis. Schultz (1959: 11) did not examine the type but nevertheless identified the species as $M$. inequalis and confused specimens of both these species and M. microlepis as M. microlepis. See also discussions under $M$. microlepis and $M$. inequalis. The fine photograph of $M$. lateralis published in Axelrod (1959: 12) was identified as $M$. microlepis therein, as $M$. barberi in Harald Schultz (1959: 47), as M. inequalis in L. P. Schultz (1959: 8) and as M. tenuis by Géry (1977: 357). L. P. Schultz (1959: 11), again without examining the type specimen, identified $M$. tenuis actually a male of $M$. lateralis, as a specimen of M. microlepis.

The specimens of $M$. lateralis, USNM 94117, that were used by Rachow (1928: 15) and Myers in Eigenmann \& Myers (1929: 493), to identify species Mimagoniates species imported into Europe and North America from eastern Brazil. Myers, in Eigenmann \& Myers (1929: 493), lists the total lengths of these specimens as $47-53 \mathrm{~mm}$. The longest total length we could find was $43.2 \mathrm{~mm}$. We are unable to explain the disparity, but is no doubt that Myers (1929) sent these specimens to J. R. Norman for comparison with specimens of $M$. barberi as indicated by the accompanying note by Myers (1929) that states that the specimens were found identical to the types of M. barberi by Norman (see also Myers, in Eigenmann \& Myers 1929: 493). This information was relayed to Rachow and constituted the source of misidentification of $M$. lateralis by aquarists for many years. This lot also has two labels in it by L. P. Schultz. The first notes that L.P. Schultz compared these specimens with his types of M. barberi (USNM 179827) and found them "not identical". We agree with L.P. Schultz but the other note in L.P. Schultz's handwriting labels these specimens as "Mimagoniates inequalis", a misidentification.

Material examined. Holotype. AMNH 4072, adult female, 29.6

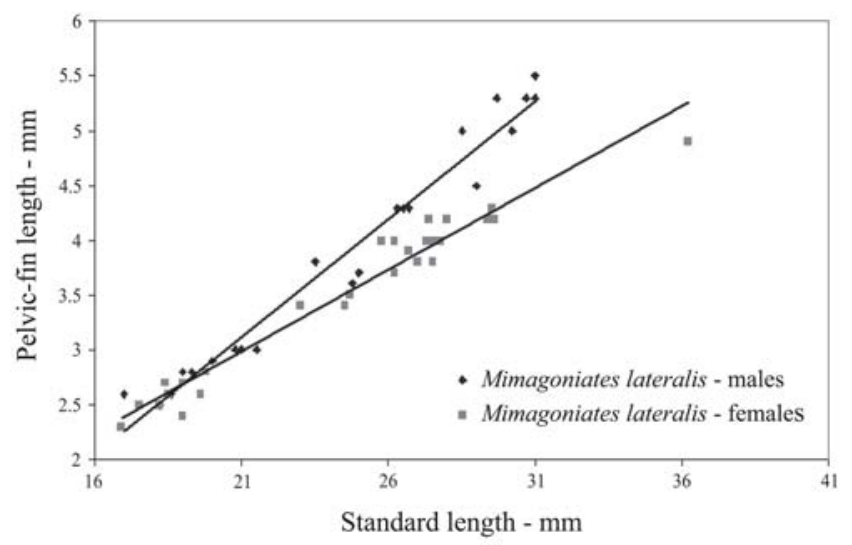

Fig. 61. Mimagoniates lateralis. Pelvic-fin length as function of SL by sex. 


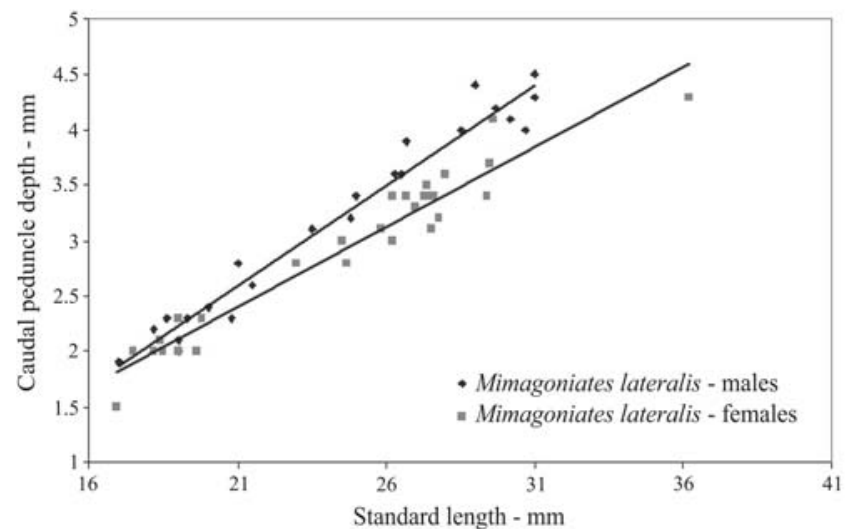

Fig. 62. Mimagoniates lateralis. Caudal peduncle depth as function of SL by sex.

mm SL, no locality data. Types of Coelurichthys tenuis. AMNH 4087 (holotype), adult male, 30.0 mm SL, no locality data; AMNH 4088 (catalogued as a cotype but not called a type in Nichols, 1913:152), adult male, 29.7 mm SL, no locality data. Non-types. All collected in Brazil. USNM 254266, 1 young adult male, 2 adult females, 23.4-25.4 mm SL, São Paulo, “small blackwater stream south of Santos”; CAS 36634, spms 90, young to adults, 8.7-31.6 mm SL, São Paulo, “second stream east of Fazenda São Luis, near Santos”; USNM 257200, 4 young to adult males, 27.3-31.4 mm SL, 3 young to adult females, 24.3-25.7 mm SL, São Paulo, Itanhaém; MZUSP 53274, spms 8 males, 27.5-34.7mm SL, 1 female, SL $27.0 \mathrm{~mm}$, adults; USNM 326250, 66, young to adults, 12.1-36.2 mm SL, São Paulo, small blackwater stream where crosses road SP 193, about $11 \mathrm{~km}$ from center of town of Cananéia; USNM 326784, 66, young to adults, 11.2-31.3 mm SL; MZUSP 53275, 75 young to adults, SL 12.0-31.0 mm; USNM 226468, 2 adults, male and female 31.0-32.6 mm SL, field color photograph and black and white of preserved specimens, Paraná, road between Matinhos and Paranaguá at km 11, roadside ditch, blackwater; USNM 257202, 10 adults, 22.3-32.0 mm SL; USNM 94117,16 adults, 23.5-32.5 mm SL, Paraná, Paranaguá (Note: According to a note these are aquarium specimens received from Arthur Rachow for identification. See discussion of $M$. lateralis below); USNM 236564, adult male, c\&s, $31.4 \mathrm{~mm}$ SL, removed from USNM 94117; MNRJ 6397, 42 young to adults, 12.8-36.9 mm SL, Paraná, Paranaguá, “estrada do mar” (= road eastward along the estuary of Baía de Paranaguá toward the Atlantic Ocean, see Myers, 1952: 131 and upper fig. p. 132) at $\mathrm{km} 9.5$, Rio Vila, $25^{\circ} 33^{\prime} \mathrm{S} 24^{\circ} 25^{\prime} \mathrm{W}$; MZUSP 20495, 20 young to adults, 17.5-27.5 mm SL, Paraná, small blackwater stream 5 km of Guaratuba, 255' 'S 48 $37^{\circ} \mathrm{W}$; USNM 236081, 1 female, 1 male, 26.5-27.5 mm SL, c\&s; USNM 236088, 1 male, 1 female, 31.3-31.6 mm SL, c\&s; USNM 254259, 21 immatures to adults, 18.7-31.8 mm SL; USNM 254267, 3 adult males, 30.1-37.6 mm SL, USNM 254265, 7 young to adults, 16.9-29.2 mm SL, USNM 254268, 1 male, 1 female, 29.8-29.9 mm SL; USNM 257201, 5, immature to adults, 20.6-36.0 mm SL; USNM 257113, 18 immatures to adults, 20.4-29.5 mm SL, USNM 254258, 20 juveniles to adults, 19.2-33.0 mm SL, Santa Catarina, rio Vermelho, Barra do Sul in Ilha de São Francisco, about 35 km from Joinville, 26¹4'S 48³5'W; USNM 177703, 6, young adults to adults, 24.3-31.8 mm SL, "Rio Grande do Sul, Porto Alegre" (Note: This last locality, as reported, is undoubtedly wrong. These aquarium specimens were probably imported from Porto Alegre but not captured there).

\section{Mimagoniates sylvicola Menezes \& Weitzman, 1990 Figs. 63-64}

Species A, Weitzman et al., 1988, figs. 6, 10 (phylogeny and biogeography).

Mimagoniates sylvicola Menezes \& Weitzman, 1990: 387, figs. 7-13 (type locality: Brazil, Bahia, município de Prado, forest stream tributary to Atlantic Ocean, near Fazenda Embaçuaba, approximately 8-9 km northwest of Cumuruxatiba, $17^{\circ} 05^{\prime}$ S 39¹3’W, 20 Mar 1985, N. Menezes, R. M. C. Castro; discussions of phylogeny and biogeography). - Oyakawa, 1996: 481 (listed in type catalog). - Weitzman et al., 1996a: 206 (distribution). Malabarba \& Weitzman, 1999: 84 (listed in discussion). Weitzman, 2003: 226 (maximum length; distribution; remarks and references). - Machado et al., 2005: 73 (conservation status). - Menezes et al., 2007: 127 (photograph; distribution; systematic status; ecology; conservation status). - Menezes, 2007: 39 (listed in catalog; distribution; conservation status). - Menezes et al., 2008: 38-40 (distribution; discussion of relationships and biogeography).

Diagnosis. Mimagoniates sylvicola is morphologically most similar to $M$. lateralis, both species having the modified caudal-fin rays forming the caudal-fin ray pump very much alike (Figs. 67a and 68) and no hooks on caudal-fin rays, characters not present in any other species of the genus. They can be distinguished by the following characters: lateral series scales 49-56 (vs. 35-41 for M. lateralis), scale rows between dorsal-fin and anal-fin origins 16-18 (vs. 12-15 for $M$. lateralis). Preserved and live colors differ between the species. Preserved males of M. sylvicola with dark lateral body stripe relatively pale and diffuse, occurring mostly at and partly dorsal to mid-lateral body region. Approximately dorsal half of opercle dark, nearly black (relatively pale in $M$. lateralis). Mimagoniates lateralis with dark, relatively narrow, clearly defined lateral body stripe that lies mostly ventral to mid-lateral body region. Dark stripe continues onto ventral one-third of opercle. Males of M. sylvicola with distal onefourth to one-fifth (less posteriorly) of anal-fin rays black (distal two-thirds to one-half black in M. lateralis). Males of $M$. lateralis with distal one-fourth of most elongate anterior unbranched ray and branched portions of anterior five to six branched rays hyaline or with a thin scattering of dark chromatophores, never black as in M. sylvicola. Life color of these species quite different. Male M. sylvicola with dorsally located black lateral "stripe" obscured by silvery blue reflective color, especially anteriorly. Ventrally located black stripe of male $M$. lateralis deep black except at its mid-length ventral to dorsal-fin origin where partly obscured by blue to silvery pigment in some population samples. Wild caught males of $M$. lateralis with a yellow-orange stripe just ventral to black lateral stripe, absent in $M$. sylvicola, although both species often with anal-fin base yellow to orange. Mimagoniates sylvicola can be distinguished from the remaining species of the genus by the absence of hooks on principal caudal-fin 
rays (vs. presence of hooks in $M$. rheocharis and $M$. microlepis, Figs. 75 and 85) and by the presence of a well-developed caudal-fin ray pump ( $v s$. caudal-fin ray pump rudimentary in M. inequalis, M. barberi and M. pulcher, Figs. 32, 38 and 47).

Description. Table 10 presents morphometrics of holotype and paratypes. Except where noted, entire description refers to lots from near Cumuruxatiba. These collections are treated statistically as one population sample since no statistical differences were found among them. Counts for specimens from rio Camurugi are given only when they differ from those from near Cumuruxatiba.

Body compressed, moderately elongate; body deepest about midway between snout tip and dorsal-fin origin, near vertical through pelvic-fin origin. Predorsal body profile gently convex to snout tip, less so in adut females and juveniles.
Body profile slightly elevated at dorsal-fin origin, straight along dorsal-fin base and nearly straight to origin of dorsal procurrent caudal-fin rays in all specimens. Dorsal-fin origin nearer to caudal-fin base than to snout tip. Ventral profile of body convex in adult males from tip of lower jaw to point on abdomen about midway between pectoral- and pelvic-fin bases, less convex in adult females and immatures. Abdominal profile abruptly becomes concave and then straight to vertical through anal-fin origin. Body profile slightly convex along anal-fin base to anal-fin insertion. Ventral profile of caudal peduncle slightly convex, especially in adult males where ventral procurrent caudal fin rays enters profile. In females and juveniles this profile nearly straight.

Lower jaw protruding beyond upper jaw. Lower jaw of males thick and heavy compared to that of females. Mouth angled posteroventrally. Maxilla extending posteriorly to point

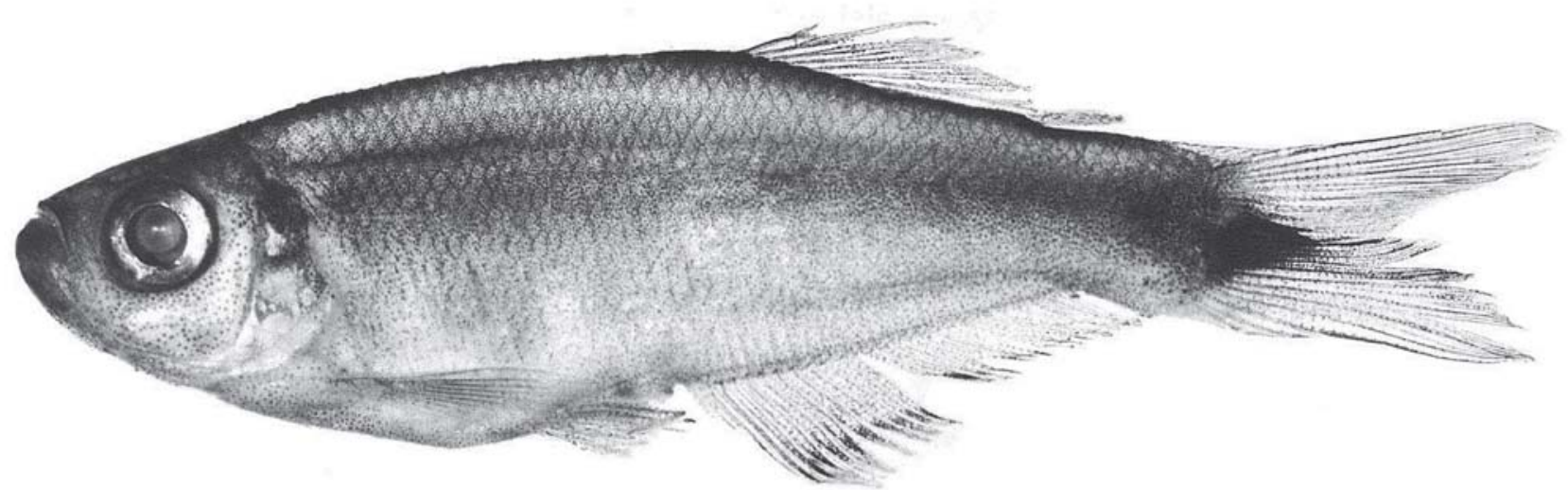

Fig. 63. Mimagoniates sylvicola, young adult male, MZUSP 36612, holotype, $30.2 \mathrm{~mm}$ SL, Brazil, Bahia, município de Prado, unnamed forest rivulet near Fazenda Embaçuaba, 8-9 km NW of Cumuruxatiba. Modified from Menezes \& Weitzman (1990).

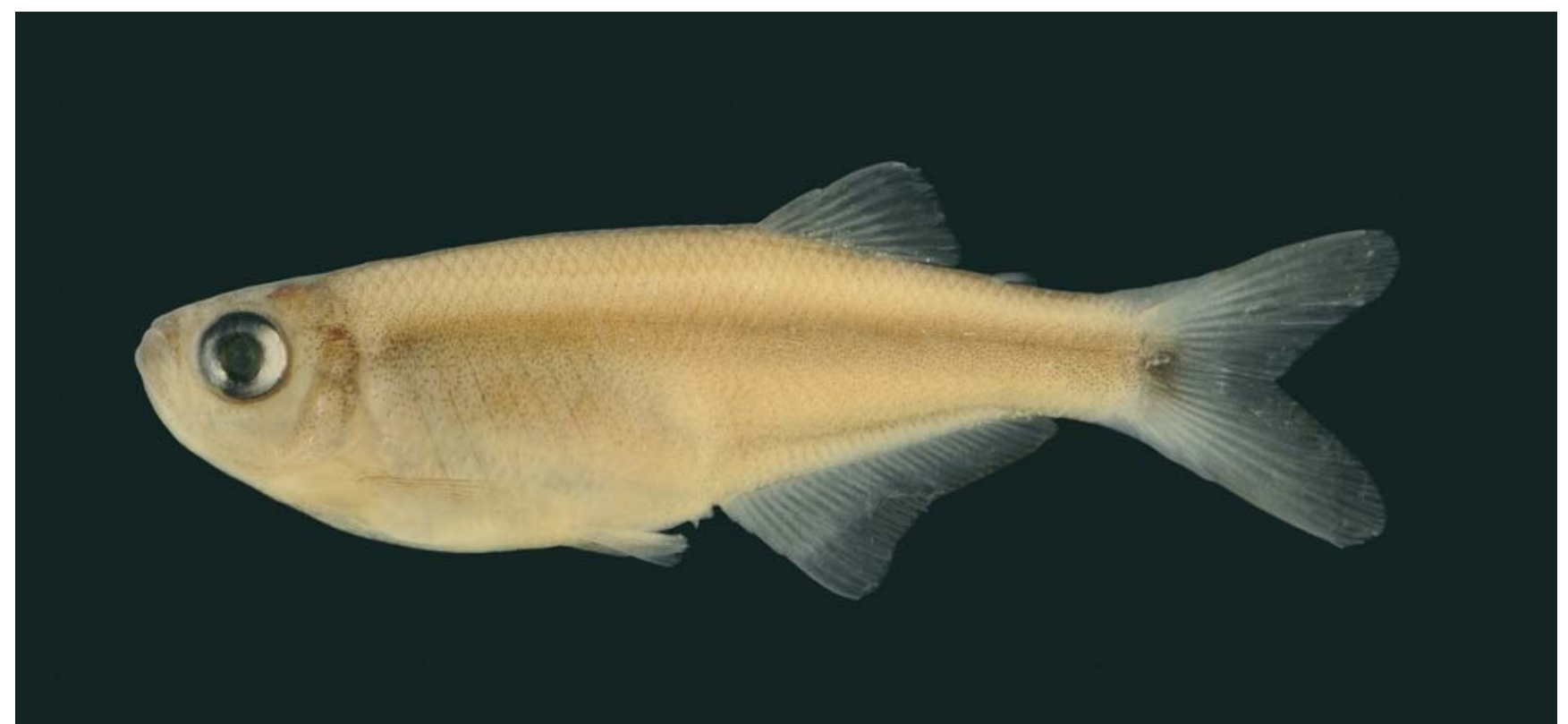

Fig. 64. Mimagoniates sylvicola, adult female, MZUSP 93873, Brazil, Bahia, município of Canavieiras, stream between Ouricana and Santa Luzia. 
Table 10. Morphometrics of Mimagoniates sylvicola. Standard length is expressed in mm; measurements through bony head length are percentages of standard length; the last four entries are percentages head length. A plus sign under the abbreviation dif. indicates there is a significant statistical difference between the males and females in the particular character indicated. All specimens are from near Cumuruxatiba, Bahia, Brazil. MZUSP 28815, MZUSP 28816, MZUSP 28817, MZUSP 36612; USNM 276547, USNM 276556, and USNM 276557. SD = Standard deviation.

\begin{tabular}{|c|c|c|c|c|c|c|c|c|c|c|}
\hline \multirow{2}{*}{ Characters } & \multicolumn{5}{|c|}{ Males } & \multicolumn{4}{|c|}{ Females and juveniles } & \multirow[b]{2}{*}{ dif. } \\
\hline & Holotype & $\mathrm{N}$ & Range & Mean & SD & $\mathrm{N}$ & Range & Mean & SD & \\
\hline Standard length & 30.2 & 44 & $17.0-30.2$ & 22.1 & & 45 & $14.5-26.6$ & 19.4 & & \\
\hline Depth at dorsal-fin origin & 29.1 & 44 & $21.5-29.3$ & 25.7 & 2.2 & 44 & $20.6-27.2$ & 23.9 & 1.6 & + \\
\hline Snout to dorsal-fin origin & 61.6 & 44 & $57.0-63.8$ & 60.0 & 1.3 & 44 & $57.2-62.2$ & 60.1 & 1.2 & - \\
\hline Snout to pectoral-fin origin & 28.1 & 44 & $24.7-29.0$ & 26.6 & 1.1 & 44 & 24.3-27.4 & 25.9 & 0.7 & - \\
\hline Snout to pelvic-fin origin & 43.4 & 44 & $39.7-45.9$ & 43.3 & 1.3 & 44 & $40.0-46.8$ & 43.2 & 1.5 & - \\
\hline Snout to anal-fin origin & 55.6 & 44 & $55.0-59.5$ & 57.2 & 1.2 & 44 & $54.3-60.9$ & 56.9 & 1.5 & - \\
\hline Caudal peduncle depth & 13.2 & 44 & $08.7-14.2$ & 11.6 & 1.4 & 44 & $8.5-11.6$ & 10.0 & 0.7 & + \\
\hline Caudal peduncle length & 12.3 & 44 & $10.1-13.8$ & 12.1 & 0.8 & 44 & $10.1-13.8$ & 12.0 & 0.9 & - \\
\hline Pectoral-fin length & 23.2 & 44 & $20.6-24.7$ & 22.6 & 0.9 & 44 & $20.2-24.5$ & 22.5 & 1.1 & - \\
\hline Pelvic-fin length & 14.9 & 44 & $11.7-16.0$ & 13.9 & 1.1 & 44 & $11.1-14.2$ & 12.7 & 0.8 & + \\
\hline Dorsal-fin base length & 14.2 & 44 & $11.9-16.5$ & 14.0 & 0.9 & 44 & $11.8-15.1$ & 13.6 & 0.1 & - \\
\hline Dorsal-fin height & 19.2 & 44 & $15.9-21.9$ & 18.5 & 1.3 & 41 & $14.4-20.6$ & 17.5 & 1.4 & - \\
\hline Anal-fin base length & 33.4 & 44 & $29.5-34.5$ & 32.6 & 1.1 & 44 & $30.4-35.2$ & 32.6 & 1.1 & - \\
\hline Anal-fin lobe length & 19.2 & 44 & $17.9-22.5$ & 20.3 & 1.0 & 43 & $17.2-22.5$ & 20.1 & 1.1 & - \\
\hline Eye to dorsal-fin origin & 46.4 & 44 & 43.6-48.4 & 46.3 & 1.1 & 44 & $42.8-51.0$ & 46.2 & 1.3 & - \\
\hline Dorsal-fin origin to caudal-fin base & 43.7 & 44 & 39.4-45.6 & 42.3 & 1.4 & 44 & $39.8-46.9$ & 42.2 & 1.4 & - \\
\hline Bony head length & 27.8 & 44 & $24.7-28.5$ & 26.6 & 0.9 & 44 & $24.7-27.9$ & 26.0 & 0.6 & - \\
\hline Horizontal eye diameter & 35.7 & 44 & $35.0-44.1$ & 39.3 & 2.2 & 45 & $39.0-44.4$ & 41.6 & 1.3 & - \\
\hline Snout length & 22.6 & 44 & $21.0-26.0$ & 23.4 & 1.2 & 45 & 21.6-26.1 & 23.9 & 1.2 & - \\
\hline Least interorbital width & 33.3 & 44 & $32.1-37.5$ & 34.7 & 1.3 & 45 & $32.0-37.0$ & 35.0 & 1.3 & - \\
\hline Upper jaw length & 45.2 & 44 & $41.3-48.2$ & 45.7 & 1.7 & 45 & $42.1-47.8$ & 45.3 & 1.5 & - \\
\hline
\end{tabular}

anterior of vertical through anterior border of pupil.

Dorsal-fin unbranched rays ii in all specimens, branched rays $8-9$, (8), 8.0 (3 specimens with 9 ), $n=90$; of 6 specimens from rio Camurugi (not included in $n=90$ ) 2 with 8 and 4 with 7 branched rays; posterior ray not split to its base and counted as 1 ray. Adipose fin slender. Anal-fin unbranched rays iv in all specimens, branched rays 23-26 (25), 24.8, $n=90$; posterior ray split to its base and counted as 1 ray. Anal fin with moderately developed lobe; anterior portion including last unbranched ray and first 5-6 branched rays. Anal fin of sexually mature males with bilateral blunt hooks on anterior 6 branched fin rays, 1 set of hooks for each ray (Fig. 65). Pectoral-fin unbranched rays $i$ in all specimens, branched rays 9-11 (10),

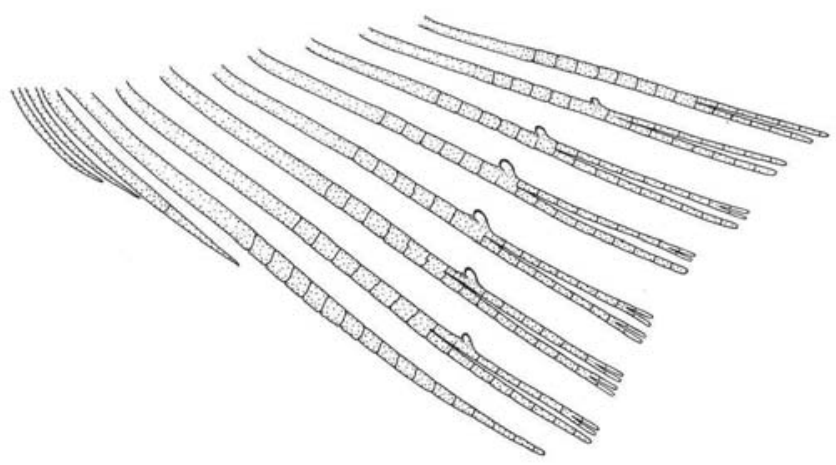

Fig. 65. Mimagoniates sylvicola, adult male, USNM 300634 , $32.5 \mathrm{~mm}$ SL; anterior 11 anal-fin rays, lateral view, left side. Modified from Menezes \& Weitzman (1990).
9.7, $\mathrm{n}=90$; all 6 specimens from rio Camurugi with 10 branched rays. Posterior tips of longest pectoral-fin rays extend posteriorly beyond origin of pelvic fin; of about equal length in both sexes. Pelvic-fin rays 7 ( 7 in all specimens except 1 with $8, n=90$, [count 8 for pelvic-fin rays of $M$. sylvicola in Menezes \& Weitzman (1990: 391) is error]. Pelvic fin with anterior most ray branched in all specimens (Fig. 66). Adult males with total of over 100 small to tiny hooks present on

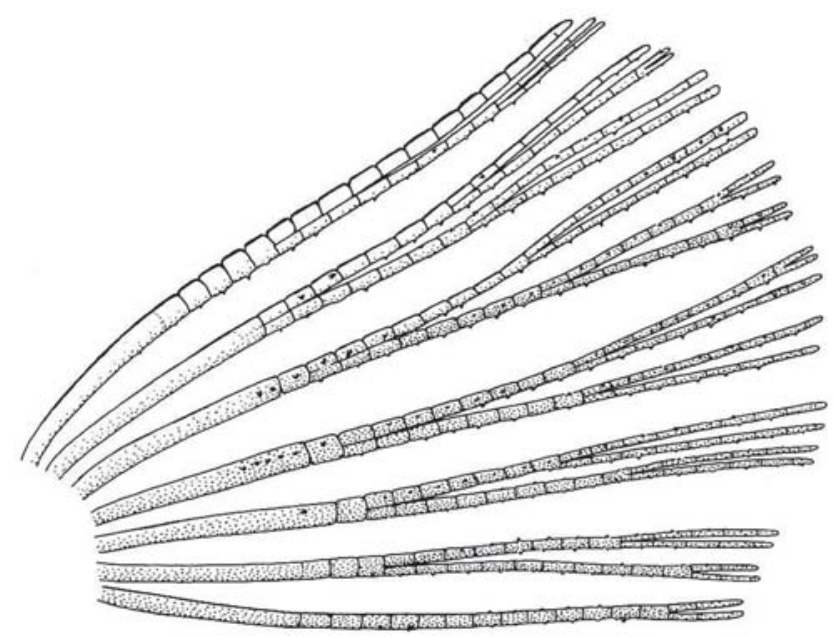

Fig. 66. Mimagoniates sylvicola, adult male, USNM 276557, $29.3 \mathrm{~mm}$ SL; pelvic-fin rays of adult male, ventral view, left side, anterior at left. Modified from Menezes \& Weitzman (1990). 
rays of pelvic fin, distributed as shown in Fig. 66. Each ray bears 9 to over 40 hooks, depending on the maturity of the specimen and/or the fin ray.

Principal caudal-fin ray count 10/9 in all specimens, $n=90$. Fin rays modified in association with caudal pheromone pump as in Figs. 67 and 68. Fig. 68 illustrates a relatively immature pump, while fig. 67 shows a presumably mature pump in which pump chamber has well-developed water entrances and exit.

Scales cycloid, almost deciduous, with few radii along posterior border; smallest scales often nearly without or without radii. Terminal scale of modified caudal series with exaggerated radii appearing as incisions of posterior scale borders (Figs. $67 \mathrm{~b}$ and $68 \mathrm{~b}$ ).

Lateral line incomplete, perforated scales 6-8 (8), 7, $\mathrm{n}=34$; 2 specimens from rio Camurugi with 9 perforated scales.

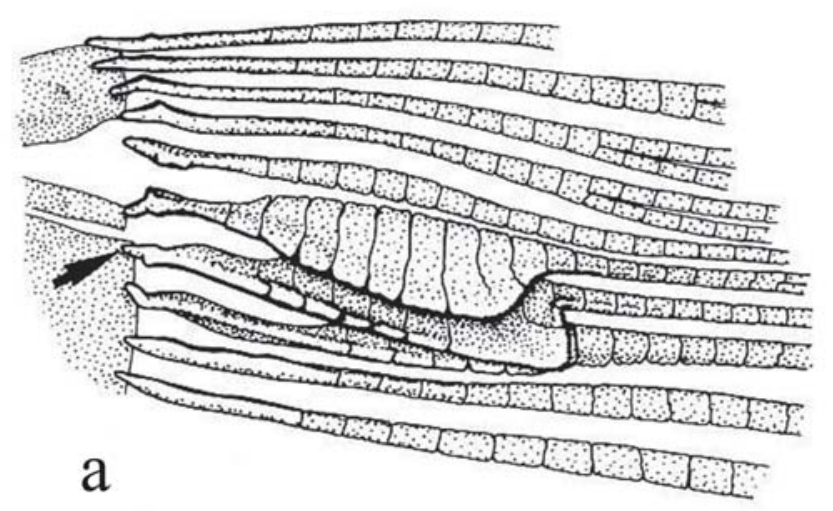

Lateral series scales 49-56 (53), 52.7, $\mathrm{n}=34$. Predorsal scales 24-28 (25), 25.9, $\mathrm{n}=39$. Scale rows between dorsal- and analfin origin 16-18 (17) 16.7, $\mathrm{n}=64$. Scale rows around caudal peduncle 19-20 (20), 19.7, $\mathrm{n}=21$; 1 specimen from rio Camurugi with 22 scale rows around caudal peduncle.

Premaxillary teeth in 2 distinct rows although this not apparent in Fig. 69. Larger teeth tricuspid, smaller teeth tricuspid or bicuspid, smallest ones unicuspid. Outer row teeth 3-7 (6), 5.4, $n=90$. Inner row teeth 3-7 (3), 3.0, $n=90$. Maxillary teeth 5-10 (6), 6.8, larger specimens usually with highest counts, $\mathrm{n}=90$; two specimens from rio Camurugi with 11 maxillary teeth. Maxillary teeth show increase in number with increasing SL from mean of 5.9 in 9 specimens of 15.5 to $16.5 \mathrm{~mm}$ SL to mean of 7.6 in 14 specimens of 25.0 to $30.5 \mathrm{~mm}$ SL. Anterior 45 maxillary teeth tricuspid and larger than remaining teeth

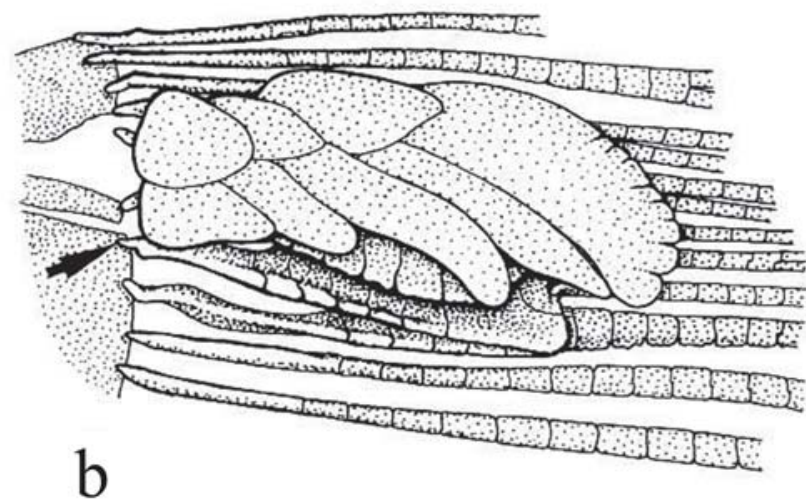

Fig. 67. Mimagoniates sylvicola, adult male, USNM 300364, $32.5 \mathrm{~mm}$ SL; osteology of central basal region of caudal-fin skeleton, principal fin rays 6-15, lateral view, left side, anterior at left. Principal caudal-fin ray 12 indicated by arrow. (a) Illustrates area of fully developed caudal organ. (b) Illustrates relationship of modified dorsal-fin squamation to pump chamber skeleton. Modified from Menezes \& Weitzman (1990).
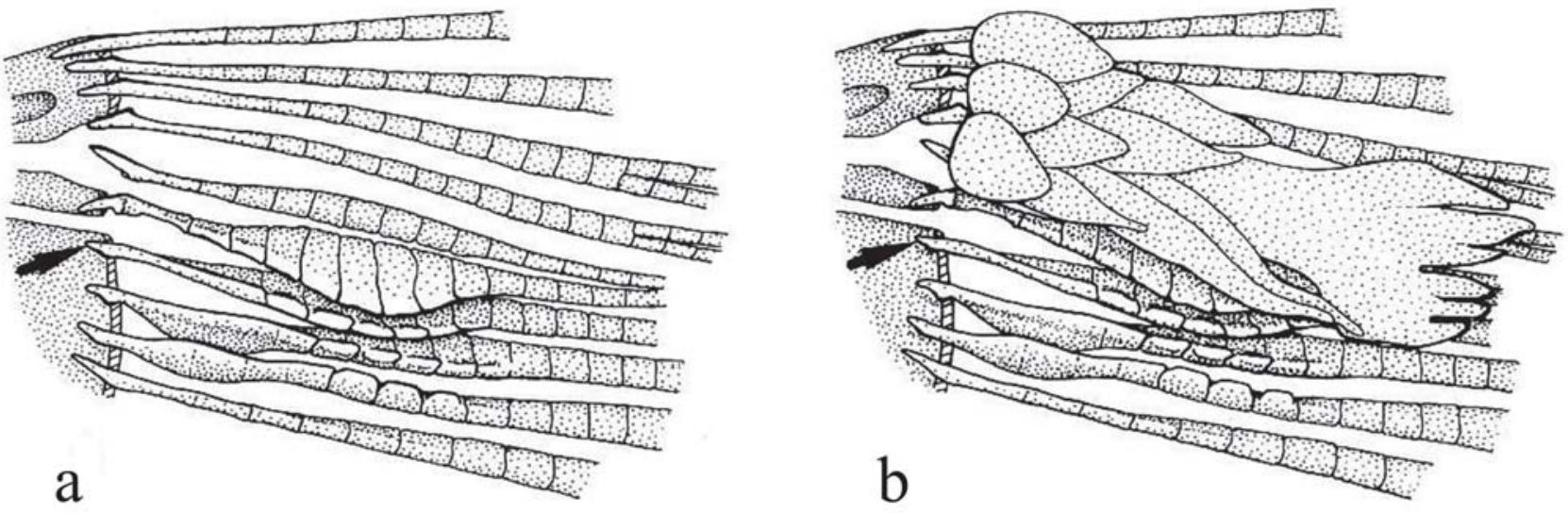

Fig. 68. Mimagoniates sylvicola, adult but still developing male, USNM 276557, $29.3 \mathrm{~mm}$ SL; osteology of central basal region of caudal-fin skeleton, principal fin rays 6-15, lateral view, left side, anterior at left. Principal caudal-fin ray indicated by arrow. (a) Illustrates area of fully developed caudal organ. (b) Illustrates relationship of modified dorsal-fin squamation to pump chamber skeleton. Modified from Menezes \& Weitzman (1990). 


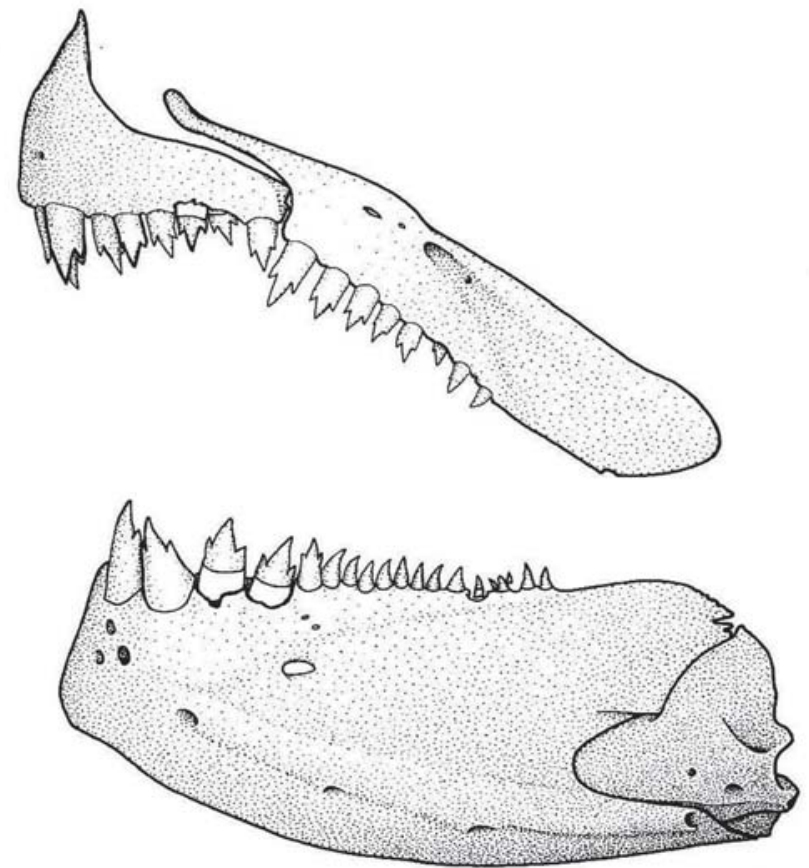

Fig. 69. Mimagoniates sylvicola, adult male, USNM 276557, $29.3 \mathrm{~mm}$ SL; jaws and dentition of adult male, lateral view, right side, anterior at left. Modified from Menezes \& Weitzman (1990).

with 1 or 2 cusps (Fig. 69). Dentary with 4 large anterior tricuspid teeth in all specimens, $\mathrm{n}=90$; smaller posterior dentary series unicuspid except tricuspid anterior most tooth, 6-12 (10), 8.9, n = 90 (Fig. 69). One specimen from rio Camurugi with 13 dentary teeth. Maxillary and dentary teeth shaped much like premaxillary teeth.

Vertebrae 39-41 (40), 39.9, $\mathrm{n}=88$. Dorsal limb gill-rakers 67 (6), 6.0, $\mathrm{n}=90$, two specimens from rio Camurugi with 5 dorsal limb gill-rakers; ventral limb gill-rakers 11-13 (12), 11.7, $\mathrm{n}=90$. Branchiostegal rays 4 in 3 cleared and stained specimens, 3 rays originating from anterior ceratohyal and 1 ray from posterior ceratohyal.

Color in alcohol. See Figs. 63 and 64 for preserved color pattern in males and females. Body pale to medium brown, almost white ventrally, darkest dorsally. Lateral body stripe pale, diffuse, best developed in males. Stripe extending from darker opercular spot on dorsal half of opercle posteriorly to dark, spot-like region on caudal peduncle. Immediately posterior to spot caudal gland region covered by black pigment forming triangular-shaped area with its posterior apex and continuous onto ray 11 and to certain extent ray 12 . Remainder of caudal fin dusky due to scattering of dark chromatophores, especially along ventral border of $19^{\text {th }}$ principal caudal ray. Dorsal body surface dark dusky, especially in area of predorsal scales.

Pectoral, pelvic, dorsal, and anal fins dusky from scattered dark chromatophores along fin rays. Pelvic fins considerably darker than pectoral fins. Anal fin with a dark, elongate stripe running length of fin. Width of stripe about one-fourth to one-fifth height of fin. Stripe borders distal ends of fin rays posteriorly; anterior portion of dark stripe separated from distal ends of first five or six fin rays by relatively hyaline area on anterior lobe of fin. Dorsal fin with horizontal dark stripe extending posteriorly from about mid-length of anterior elongate unbranched ray to posterior tips of two terminal dorsal-fin rays. Adipose fin dusky with scattered dark chromatophores. Head dark brown around mouth and on dorsal surface of snout, between eyes, dorsal portion of cranium and nape. Iris dorsal to pupil dark brown to black, most of remainder of iris silvery with some dark brown or black areas ventrally. Infraorbitals pale brown or silvery with evenly scattered dark chromatophores. Ventral area of opercle, preopercle and posterior region of branchiostegal rays silvery, without much dark brown pigment.

Color in life. Life color patterns taken from color slides and color notes made while collecting specimens from clear and black waters near Cumuruxatiba. Sides of body silvery deep blue with dorsal region dark brown and abdominal area silvery white. All fins translucent, lemon yellow with dark brown pigment described above under preserved color description appearing brown to black. Females with similar color pattern but blue, yellow, and dark pigment patterns much paler. Caudal-fin rays 13 and 14 considerably darkened with black pigment in life. Some male specimens display considerable but rather diffuse lateral dark brown stripe below lateral midregion of body. Specimens from rio do Sul, Cumuruxatiba area (USNM 276547), gold silvery in color and without blue coloration. Some with black pigment considerably reduced, absent, or covered in patches by guanine, especially on lateral surface of body sides.

Sexual dimorphism. Females lack caudal pheromone pump organ, anal-fin and pelvic-fin hooks of males and display more subdued live body coloration as noted above. Table 10 indicates significant differences in body depth, caudal peduncle depth, and pelvic-fin length between males and females. The regression analyses and the discussion of these sexually dimorphic differences are presented in the "sexual dimorphism section” for this species in Menezes \& Weitzman (1990: 394-396).

Distribution. Mimagoniates sylvicola is known from small streams in southern Bahia, Brazil. See figure 3 in Menezes et al. (2008).

Ecology. Ecological notes for this species are presented in Menezes \& Weitzman (1990: 398-399). However, since the time the specimens of $M$. sylvicola were collected, the environment where they live was severely altered. The tall forest protecting creeks and rivulets and providing shade for the cocoa plantations in southern Bahia was mostly removed and the trees used in wood production after the drastic decrease in the price of cocoa. As a consequence the species is now at risk of becoming extinct since it is restricted to those particular 
types of habitats. Further information is available in Menezes \& Lima (2008).

Material examined. Holotype. MZUSP 36612, adult male, 30.2 mm SL, Brazil, Bahia, município de Prado, forest stream tributary to Atlantic Ocean, near Fazenda Embaçuaba, approximately 8-9 km northwest of Cumuruxatiba, $17^{\circ} 05^{\prime}$ S $39^{\circ} 13^{\prime}$ W. Paratypes. Collected with holotype: MZUSP 28817, juveniles to adults 42, 15.1-30.2 mm SL; USNM 276557, juveniles to adults 42, 14.7-33.5 mm SL, 1 male SL $29.3 \mathrm{~mm}$ and 1 female $26.6 \mathrm{~mm}$ SL, c\&s. Following paratypes all collected 20 Mar 1985 by N. Menezes et al. unless otherwise noted: MZUSP 28815, 77, 11.0-27.4 mm SL; USNM 276547, juveniles to young adults 77, 14.4-27.4 mm SL, Brazil, Bahia, município de Prado, first stream (locally called rio do Sul) south of rio Caí, on road between Cumuruxatiba and Itamaraju, $17^{\circ} 00^{\prime} \mathrm{S} 39^{\circ} 12^{\prime} \mathrm{W}$. MZUSP 28816, 28, 12.7-25.1 mm SL; 6, juveniles to adults, 13.2-24.0 mm SL, Brazil, Bahia, município de Prado, small stream NW of Cumuruxatiba, about $17^{\circ} 01^{\prime}$ 'S $39^{\circ} 12^{\prime}$ 'W. USNM 300633, juveniles to adults 5, 22.3-31.3 mm SL and USNM 300634, 1, c\&s, 31.8 mm SL, Brazil, Bahia, município de Porto Seguro, riacho Ronca Água, tributary to right margin of rio Camurugi, tributary to rio João de Tiba drainage, approximately $16^{\circ} 20^{\prime} \mathrm{S}$ $39^{\circ} 07^{\prime}$ W, 19 Feb 1986, I. Rosa and party. Non-types. USNM 276556 , juveniles 25, 13.9-24.8 mm SL, same data as MZUSP 28816 above.

\section{Mimagoniates rheocharis Menezes \& Weitzman, 1990 Figs. 70-77}

Species B, Weitzman et al., 1988, figs. 6, 10, 23 (phylogeny and biogeography).

Mimagoniates rheocharis Menezes \& Weitzman, 1990: 399, figs. 19-23 (type locality: Brazil, Santa Catarina, município de Praia Grande, rio Faxinalzinho at Mãe dos Homens, near Praia Grande, approximately $29^{\circ} 20^{\prime} \mathrm{S} 14^{\circ} 40^{\prime} \mathrm{W}$; discussions of possible hybrid origin; phylogeny and biogeography).
- Oyakawa, 1996: 480-481 (listed in type catalog). - Weitzman et al., 1996b: 196, 199, 201 (photograph; illustration of caudal fin; distribution; ecological data; relationships; courtship behavior). - Malabarba \& Weitzman, 1999: 108 (distribution). - Malabarba \& Weitzman, 2000: 280 (listed in discussion); - Weitzman, 2003: 226 (maximum length; distribution; remarks and references). - Machado et al., 2005: 73 (conservation status). - Menezes, 2007: 39 (listed in catalog; distribution; conservation status). - Menezes et al., 2007: 126 (photograph; distribution; systematic status; ecology; conservation). - Menezes et al., 2008: 3841, 43 (distribution; discussion of relationships and biogeography). - Malabarba et al., 2008: 79 (conservation status; general informations; geographic distribution; main threats; conservation strategies).

Diagnosis. Mimagoniates rheocharis may be separated from all other species of Mimagoniates by the presence of sturdy hooks on some principal caudal-fin rays. Among the species of Mimagoniates presence of hooks on some caudal-fin rays also occurs in M. microlepis and M. pulcher, but in these species they are spiny. Mimagoniates rheocharis and $M$. microlepis, however, have fully developed caudal-fin ray pumps (Figs. 75 and 85) whereas in M. pulcher the pump is only partially developed (Fig. 47). Additionally M. rheocharis differs from M. microlepis by the number of scale rows around caudal peduncle (19 to 23 vs. 15 to 18 for M. microlepis) and scales rows between dorsal-fin and anal-fin origins (17 to 21 vs. 13 to 16 for M. microlepis).

A few life color characters differentiate in fully mature males: the pelvic-fin rays and membranes of adult males are distally white whereas in $M$. microlepis the yellow and/or black pigment of the pelvic fins are continuous to edge of the fin where fin is bordered by a narrow band of white; the portion

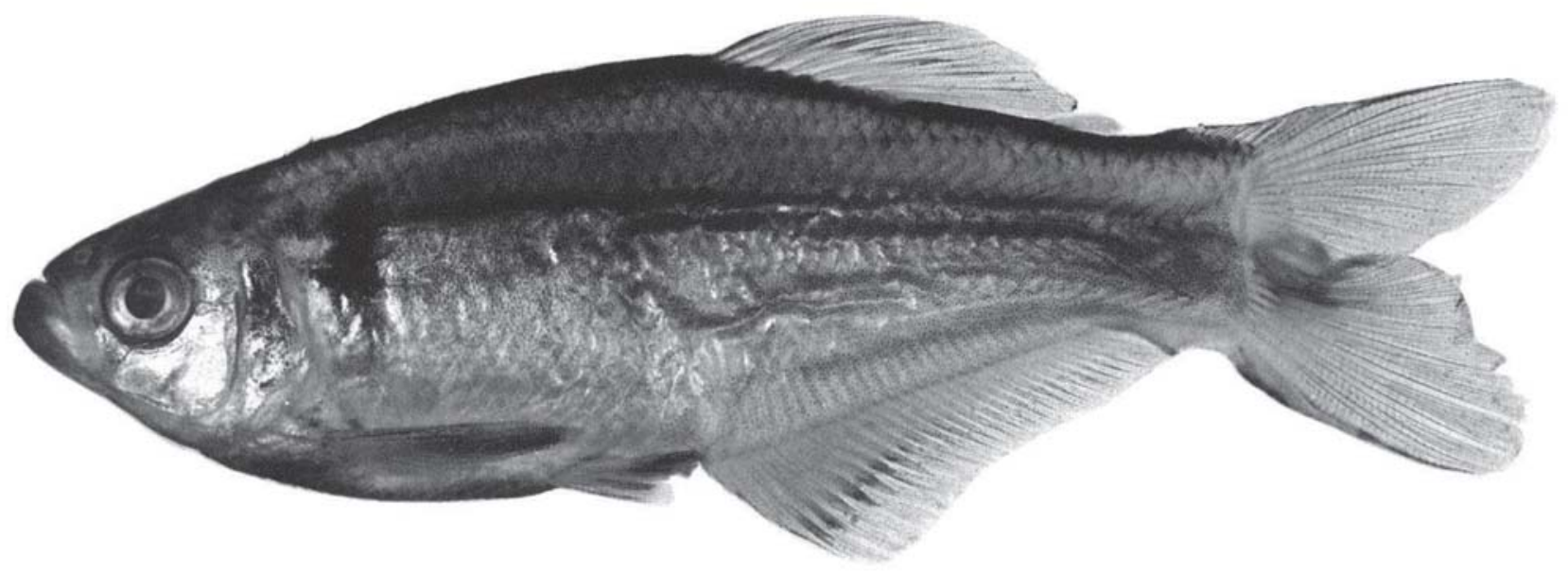

Fig. 70. Mimagoniates rheocharis, adult male, MZUSP 40278, holotype, $47.3 \mathrm{~mm}$ SL, Brazil, Santa Catarina State, rio Faxinalzinho at Mãe dos Homens, near Praia Grande. Modified from Menezes \& Weitzman (1990). 


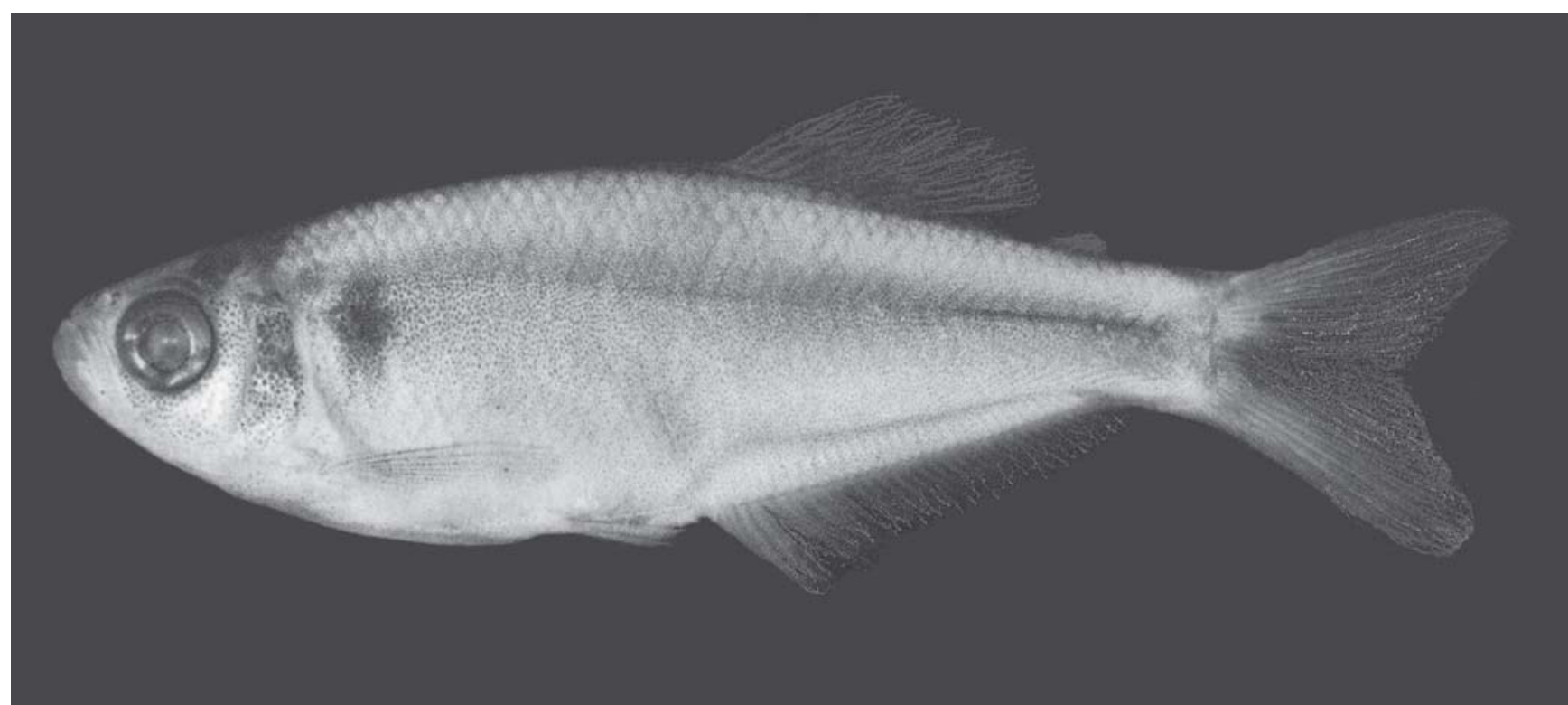

Fig. 71. Mimagoniates rheocharis, female,USNM 306339, paratype, 34.3 mm SL, Brazil, Santa Catarina State, tributary of Rio Grande. Modified from Menezes \& Weitzman (1990).

of the anal fin posterior to the anterior lobe is bordered by a broad band of deep yellow pigment, with very little to no black pigment on fin; in M. microlepis the posterior portion of the anal fin is ventrally bordered by a narrow band of black pigment, and none or very little yellow pigment.

Description. Table 11 presents morphometrics of holotype and paratypes. Except where noted, entire description refers to population sample from near Praia Grande, southern Santa Catarina. Collections treated statistically as one population sample in attempt to represent the species as a whole. Counts and ratios of measurements for other population samples taken from tributary of rio Grande given only when they differ from those from near Praia Grande.

Body compressed, relatively deep, especially near dorsalfin origin; body deepest at vertical through anal-fin origin.

Table 11. Morphometrics of Mimagoniates rheocharis. Standard length is expressed in mm; measurements through bony head length are percentages of standard length; the last four entries are percentages head length. A plus sign under the abbreviation dif. indicates there is a significant statistical difference between the males and females in the particular character indicated. Specimens are from near rio Grande, Santa Catarina, MZSUP 40280, MCP 13616, and USNM 279878, USNM 306339. $\mathrm{SD}=$ Standard deviation .

\begin{tabular}{|c|c|c|c|c|c|c|c|c|c|c|}
\hline \multirow{2}{*}{ Characters } & \multicolumn{5}{|c|}{ Males } & \multicolumn{4}{|c|}{ Females and juveniles } & \multirow[b]{2}{*}{ dif. } \\
\hline & Holotype & $\mathrm{N}$ & Range & Mean & SD & $\mathrm{N}$ & Range & Mean & SD & \\
\hline Standard length & 47.3 & 31 & $21.7-47.8$ & 32.0 & & 26 & $13.5-37.7$ & 26.4 & & \\
\hline Depth at dorsal-fin origin & 33.8 & 31 & 26.9-35.2 & 31.4 & 1.8 & 26 & $22.2-32.9$ & 29.3 & 2.3 & + \\
\hline Snout to dorsal-fin origin & 57.9 & 31 & $54.6-60.2$ & 57.6 & 1.2 & 26 & $56.2-60.7$ & 58.5 & 1.3 & - \\
\hline Snout to pectoral-fin origin & 26.6 & 31 & $25.0-27.7$ & 26.4 & 1.6 & 26 & 24.1-29.6 & 26.0 & 0.1 & - \\
\hline Snout to pelvic-fin origin & 43.4 & 31 & $40.3-47.2$ & 44.9 & 1.2 & 26 & 43.3-47.6 & 45.0 & 0.1 & - \\
\hline Snout to anal-fin origin & 58.8 & 31 & $52.3-58.8$ & 56.7 & 1.2 & 26 & $54.5-58.8$ & 56.9 & 1.0 & - \\
\hline Caudal peduncle depth & 16.0 & 31 & $11.5-16.2$ & 14.2 & 1.2 & 26 & 08.8-14.1 & 12.4 & 1.2 & + \\
\hline Caudal peduncle length & 11.4 & 31 & $7.2-13.2$ & 10.3 & 0.1 & 26 & $07.0-11.1$ & 09.5 & 1.0 & - \\
\hline Pectoral-fin length & 21.6 & 31 & $20.5-24.9$ & 23.0 & 1.1 & 26 & $18.5-24.9$ & 23.3 & 0.1 & - \\
\hline Pelvic-fin length & 12.3 & 31 & $12.2-15.0$ & 13.7 & 0.7 & 26 & 11.1-13.7 & 12.7 & 0.6 & + \\
\hline Dorsal-fin base length & 17.3 & 31 & 13.4-19.1 & 16.3 & 1.4 & 26 & $12.7-17.1$ & 15.2 & 1.1 & - \\
\hline Dorsal-fin height & 26.0 & 31 & $21.8-28.0$ & 24.1 & 1.6 & 26 & $20.7-26.2$ & 23.2 & 1.4 & - \\
\hline Anal-fin base length & 34.5 & 31 & 33.7-38.7 & 36.0 & 1.2 & 26 & 33.9-37.9 & 35.8 & 1.1 & - \\
\hline Anal-fin lobe length & 19.0 & 31 & $17.0-22.5$ & 20.0 & 0.1 & 26 & $15.6-22.5$ & 19.6 & 1.5 & - \\
\hline Eye to dorsal-fin origin & 45.9 & 31 & $41.5-48.3$ & 45.0 & 1.3 & 26 & $43.4-47.1$ & 45.3 & 1.0 & - \\
\hline Dorsal-fin origin to caudal-fin base & 46.5 & 31 & $42.6-48.5$ & 45.6 & 1.4 & 26 & $39.2-49.2$ & 45.0 & 2.0 & - \\
\hline Bony head length & 25.6 & 31 & $14.2-26.2$ & 25.3 & 0.5 & 26 & 24.4-28.1 & 25.5 & 0.8 & - \\
\hline Horizontal eye diameter & 33.1 & 31 & $35.5-42.0$ & 38.7 & 1.9 & 25 & $36.5-41.6$ & 40.0 & 1.2 & - \\
\hline Snout length & 24.8 & 31 & $20.5-24.7$ & 22.3 & 0.8 & 25 & $20.0-24.3$ & 22.0 & 1.2 & - \\
\hline Least interorbital width & 33.9 & 31 & 33.7-38.7 & 35.9 & 1.1 & 25 & 33.3-37.8 & 36.1 & 1.1 & - \\
\hline Upper jaw length & 43.8 & 31 & $42.8-48.7$ & 45.5 & 1.6 & 25 & 43.3-47.6 & 45.7 & 1.3 & - \\
\hline
\end{tabular}


Predorsal body profile relatively arched in adult males, less so in adult females and immatures which have predorsal profile gently convex to tip of snout. Body profile elevated at dorsalfin origin. Dorsal profile of body nearly straight along dorsalfin base to adipose fin. Body profile posterior to adipose fin somewhat concave dorsal to caudal peduncle. Dorsal-fin origin nearer to caudal-fin base than to snout tip. Ventral profile of body strongly convex in adult males from tip of lower jaw to origin of pelvic fins, less convex in females and juveniles. Abdominal profile in adult males slightly concave to anal-fin origin, straight or nearly so in females and juveniles. Body profile along anal-fin base in males slightly concave anteriorly along anterior lobe of anal fin; straight along base of remainder of fin in males and along entire anal-fin base in females and juveniles. Ventral profile of caudal peduncle convex in adult males; slightly concave or nearly straight in females and juveniles.

Lower jaw protruding slightly beyond upper jaw. Lower jaw of adult males thick and heavy compared to that of females and juveniles. Mouth angled posteroventrally. Maxilla long, extending to point ventral to a horizontal line through ventral border of eye. Maxilla extends posteriorly to point anterior to vertical through anterior border of pupil.

Dorsal-fin unbranched rays ii in all specimens, branched rays 8-10 (9), 8.9, $\mathrm{n}=56$; posterior ray not split to its base and counted as 1 ray. Adipose fin slender. Anal-fin unbranched iv or v, usually iv, branched rays $25-29,26.8, n=56$; posterior ray split to its base and counted as 1 ray. Anal fin with moderately developed lobe anteriorly (Figs. 70, 71 and 73); lobe includes last unbranched ray and first 3 branched rays. Anal fin of sexually mature males with bilateral hooks, 1 on each side, on last unbranched ray (Fig. 73). In most specimens anterior 7 branched fin rays with bilateral hooks, 1 set for

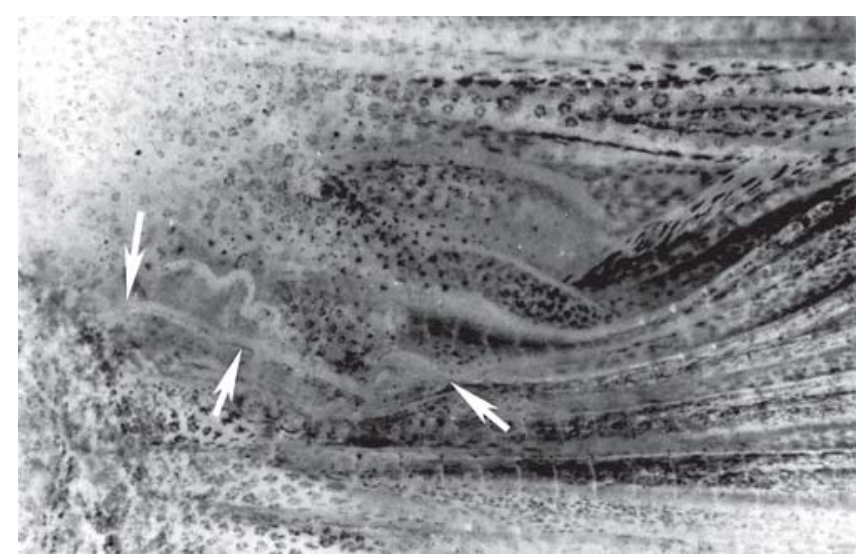

Fig. 72. Mimagoniates rheocharis, adult male, USNM 279879, $49.0 \mathrm{~mm}$ SL; central basal region of caudal-fin and adjacent caudal peduncle, lateral view, left side, anterior at left. Arrow at left indicates anterior intake region of pump chamber; middle arrow indicates region of lateral slit with ray half of principal caudal ray 11 just dorsal to arrow tip; arrow at right points to opening of posterior exhaust vent of pump chamber. Modified from Menezes \& Weitzman (1990). each ray. Pectoral-fin unbranched ray i in all specimens, branched rays 10-11, 10.1, $\mathrm{n}=56$. Tip of pectoral-fin extends posteriorly beyond origin of pelvic fins. Pelvic-fin rays 8 in all specimens. Pelvic fin with first ray branched once, branches remaining close together and entire ray tapering as in congeners in which ray unbranched (Fig. 74). Sexually mature, large adult males with over 400 hooks on each pelvic fin distributed as shown in Fig. 74.

Principal caudal-fin ray count 10/9 in all specimens, $\mathrm{n}=$ 56 . Fin rays modified in association with caudal pheromone pump as in Fig. 75. Caudal-fin rays 10 and 11 with small bony hooks. Ventral borders of 4 anterior expanded ray segments of ray 11 , which form anterior external wall of dorsal portion of pump chamber, with about 4 short but large hooks; 2 middle hooks often bicornate, others with single hook.

Scales cycloid, with few radii along posterior border. Terminal scale of modified caudal-fin series without exaggerated radii (Fig. 75b).

Lateral line incomplete, perforated scales 5-9 (7), 6.7, $\mathrm{n}=$ 48. Lateral series scales 41-48 (45), 44.3, $n=48$. Predorsal

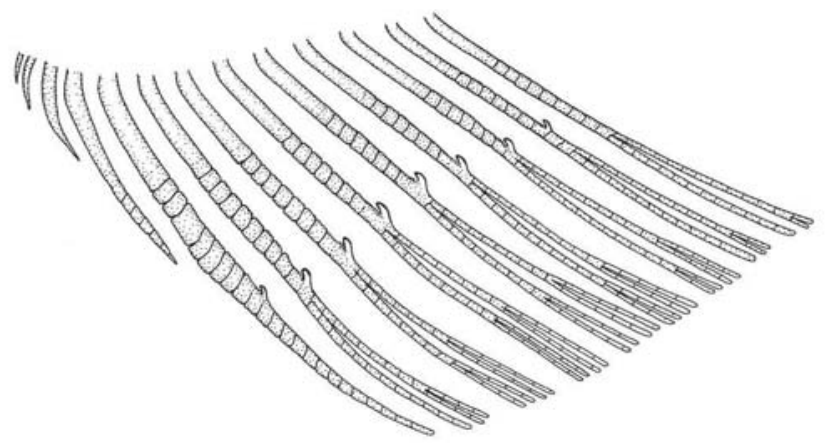

Fig. 73. Mimagoniates rheocharis, adult male, USNM 279879, paratype, $45.4 \mathrm{~mm} \mathrm{SL}$; anterior 13 anal-fin rays of adult male, lateral view, left side. Modified from Menezes \& Weitzman (1990).

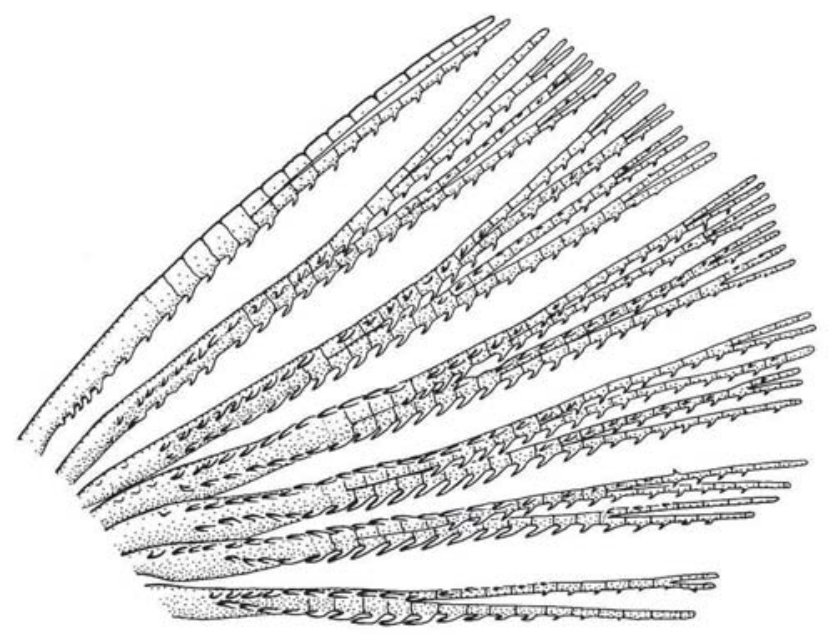

Fig. 74. Mimagoniates rheocharis, adult male, USNM 279879, paratype, $45.4 \mathrm{~mm}$ SL; pelvic fin of adult male, ventral view, left side, anterior at left. Modified from Menezes \& Weitzman (1990). 

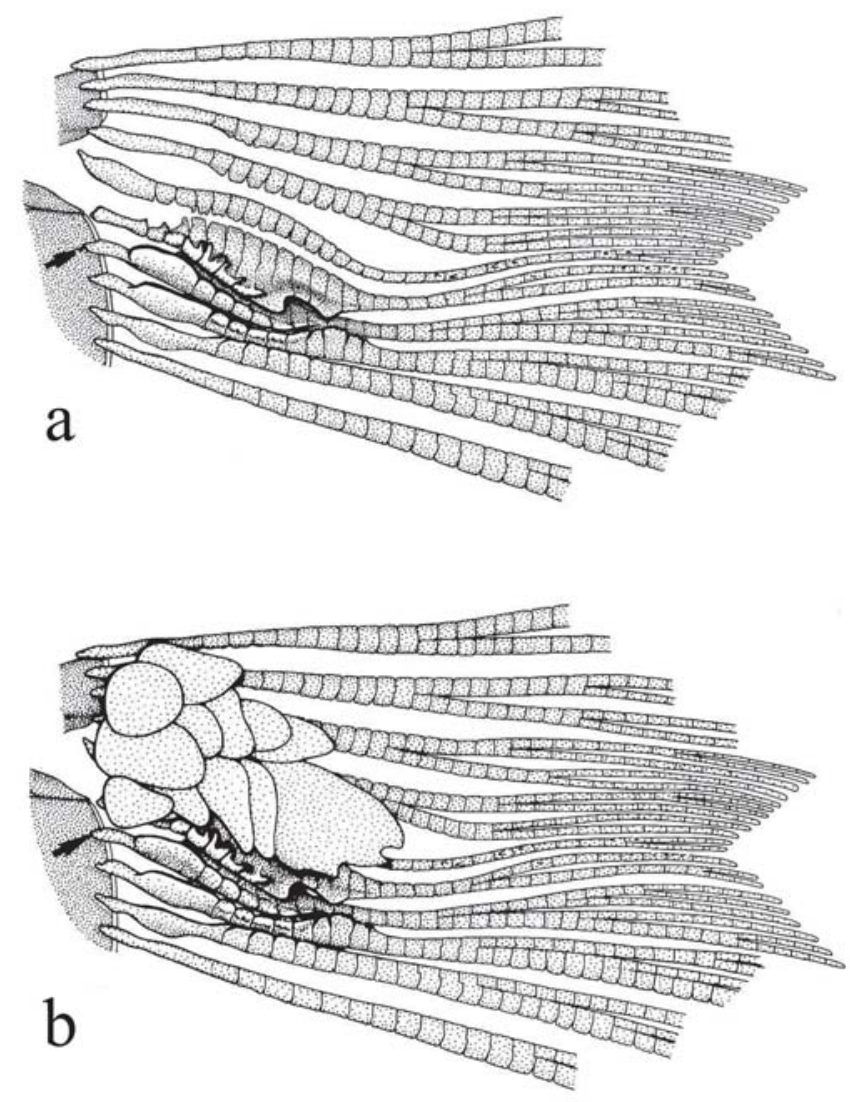

Fig. 75. Mimagoniates rheocharis, adult male, USNM 279879, paratype, $45.4 \mathrm{~mm}$ SL; osteology of central basal region of caudal-fin skeleton, principal fin rays 6-15, lateral view, left side, anterior at left. Principal caudal-fin ray 12 indicated by arrow. (a) Illustrates area of fully developed caudal organ. (b) Illustrates relationship of modified dorsal-fin squamation to pump chamber skeleton. Modified from Menezes \& Weitzman (1990).

scales $=21-24$ (22), 22.3, $n=46$. Scale rows between dorsal-fin and anal-fin origins 17-21 (19), 18.8, $\mathrm{n}=55$. Scale rows around caudal peduncle 19-22 (20), 19.7, $\mathrm{n}=46$.

Premaxillary teeth in 2 distinct rows (Fig. 76), teeth tricuspid in all large specimens, smaller teeth sometimes bicuspid or conical in smaller specimens. Outer row teeth 58 (5), 6.2, $\mathrm{n}=55$. Inner row teeth, 1-3 (3), 2.1, $\mathrm{n}=55$. Maxillary teeth 3-8 (8), 4, larger specimens usually with more teeth, $n$ $=55$. All maxillary teeth tricuspid in large specimens; small specimens with posterior teeth often conical (Fig. 76). Dentary with 4 large anterior tricuspid teeth in all specimens, followed by 5-12 (12), 8.4, smaller teeth, almost always greater number of teeth in largest specimens. Anterior small teeth of posterior dentary series tricuspid, posterior ones conical, $\mathrm{n}=54$. Maxillary and dentary teeth shaped much like premaxillary teeth.

Vertebrae 37-40 (38), 38, $n=107$. Dorsal limb gill rakers 6-8 (7), 6.6, $n=54$; ventral limb gill rakers 11-13 (12), 11.7, $n=54$. Branchiostegal rays 4, in 3 cleared and stained specimens, 3

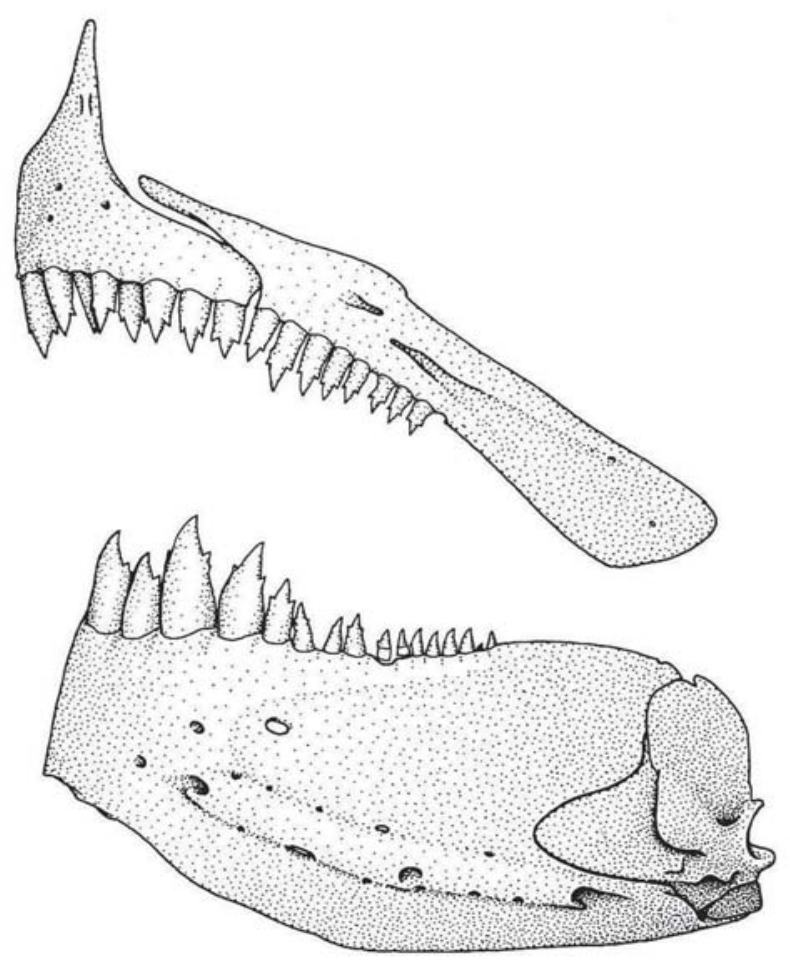

Fig. 76. Mimagoniates rheocharis, adult male, USNM 279879, paratype, $45.4 \mathrm{~mm} \mathrm{SL}$; jaws and dentition of adult male, lateral view, right side, anterior at left. Modified from Menezes \& Weitzman (1990).

rays originating on anterior ceratohyal and 1 ray from posterior ceratohyal.

Color in alcohol. See Figs. 70 and 71 for preserved color pattern of males and females. Body pale to medium brown, pale yellowish-brown ventrally, much darker dorsally. Lateral body stripe diffuse in both sexes, especially anteriorly. Stripe extending from vertical humeral spot posteriorly to caudal fin and onto dorsal region of ventral caudal-fin lobe and small part of dorsal caudal-fin lobe. Lateral stripe extends over all caudal gland structures. Stripe especially dark on principal rays 10,11 and 12 , less so on ray 13 . Humeral spot vertically elongate, especially in sexually mature males. Remainder of caudal fin dusky due to presence of scattered dark chromatophores. Dorsal border of first principal and ventral border of nineteenth principal caudal-fin rays black. Middorsal body surface black, forming narrow stripe extending from supraoccipital region to base of dorsal procurrent rays of caudal fin. Remainder of dorsal body surface ventral to lateral body stripe pale brown.

Pectoral, pelvic, dorsal, and anal fins dusky with scattered dark chromatophores along fin rays and membranes. Anal fin with dark elongate stripe running length of fin. Stripe of nearly uniform width about one-fourth height of anal fin anteriorly and about one-half height posteriorly. Sexually mature males with stripe considerably darker anteriorly, especially dorsal 
to relatively hyaline anterior anal-fin lobe. Dorsal-fin with horizontal dark stripe in adult males and females extending from about mid-length of anterior elongate unbranched ray to posterior tips of terminal two dorsal-fin rays. Stripe usually narrow, less than one-eighth maximum height of dorsal fin. Width and intensity of stripe variable depending on sex and maturity. Preserved males sometimes with posterior portion of stripe diffuse. Adipose fin dusky with scattered dark chromatophores.

Head dark brown around mouth and on dorsal surface of snout, between eyes, dorsal portion of cranium and nape. Tip of lower jaw dark brown. Head dark brown posterior to infraorbitals and from parietal region ventrally, across dorsal opercular region. Dark area continues ventrally across posterior region of opercle to just reach interopercle; looks similar in form to humeral spot. Iris dorsal to pupil dark brown, most of remainder of iris silvery. Infraorbitals silvery if guanine preserved, pale yellowish brown if guanine absent. Dark brown chromatophores scattered evenly through circumorbital area. Anterior area of opercle, all of preopercle, and branchiostegal rays silvery or pale brown, without much dark brown pigment.

Color in life. Life colors described here taken from slide of an adult male $41.8 \mathrm{~mm}$ SL (MZUSP 40281) from site located immediately north of city of Osório, Rio Grande do Sul. Sides of body pale silvery blue. Broad lateral body stripe somewhat deeper silvery blue from humeral spot to caudal peduncle termination. Just dorsal to silvery blue color of body sides, back with narrow dark brown line extending from parietal region of head to just ventral to adipose fin. Lateral portion of dorsal portion of body between narrow brown line and dorsomedian narrow dark brown line extending across dorsal most portion of back, brownish-yellow green color. Dorsal region of caudal peduncle nearly yellow. Ventral abdominal area, most of lower jaw, ventral opercular area, branchiostegal rays and their membranes silvery white. Dark pigment of head similar to that described for preserved specimens except that dorsal region of opercle appears silvery blue. Dorsal caudalfin lobe and principal caudal-fin rays 14-16 on ventral caudalfin lobe bright yellow, except for black proximal half of ray 14 . Black pigment continuous with black pigment surrounding structures of caudal pheromone organ. Rays 17-19 of ventral caudal-fin lobe hyaline or nearly hyaline except in ray 17 somewhat yellow. Remainder of black pigment of caudal fin as described above for preserved specimens. Anal fin with distal portion of fin rays posterior to anterior anal-fin lobe lemon yellow, forming stripe along ventral border of fin. Distal region of anterior anal-fin lobe hyaline to white, proximally bordered by black pigment described above for preserved specimens. Black pigment mixed with yellow. Basal half of anal fin hyaline with some scattered brown chromatophores and small amount of yellow anteriorly. Posterior portion of narrow horizontal black line of anal fin pale. Approximately distal onehalf of pelvic fin white, with black and yellow band proximal to it and remaining proximal portion of fin hyaline. Distal one-half of pectoral fins yellow, proximal half with black rays and yellow membranes. Dorsal fin hyaline to white distal and proximal to longitudinal black and brown longitudinal stripe.

Sexual dimorphism. Females lack caudal pheromone pump organ and pelvic- and anal-fin hooks described above for males. Live color of females is unknown but likely more subdued than that of sexually mature males. Table 11 indicates that of the morphometric characters showing significant differences between sexes only those related to caudal peduncle depth and pelvic-fin length are statistically different using regression analysis. See discussion in the "sexual dimorphism" section for this species in Menezes \& Weitzman (1990: 412-415).

Distribution. Mimagoniates rheocharis occurs in small coastal streams and rivers from Santa Catarina to northern Rio Grande do Sul, Brazil. See figure 3 in Menezes et al. (2008).

Ecology. In addition to the scarce information available in the ecological notes in Menezes \& Weitzman (1990: 421-422), recent data from Malabarba et al. (2008) indicates that Mimagoniates rheocharis lives in small streams with moderate flowing and shallow clear waters, with rocks and less abundant fallen leaves, sand or mud. Specimens are usually found in small numbers in still waters near the banks where the water current is slower, under the shadow of marginal vegetation. Few specimens can also be found in micro-habitats among rocks and macrophytes, especially when larger portions of still water are occupied by Mimagoniates microlepis. The species seems to be very sensitive to change in water quality especially with respect to dissolved oxygen and $\mathrm{pH}$. Feeds mainly on a variety of terrestrial insects that fall from surrounding trees and are preyed upon on the water surface. Small amounts of aquatic insects and micro-crustaceans are also eaten. Like other members of the Glandulocaudinae, $M$. rheocharis is forest-dependent and survives only in streams where the marginal vegetation is preserved.

Remarks. Menezes \& Weitzman (1990: 414-416) discussed statistical comparisons of meristic and morphometric data between $M$. rheocharis and $M$. microlepis. These are not repeated here. Although some overlap was found in many characters, significant differences were found in most of the features compared. Similar comparisons and results were made with Mimagoniates inequalis in the same publication.

Menezes \& Weitzman (1990: 416-421) discussed the possible hybrid origins of $M$. rheocharis from $M$. inequalis and $M$. microlepis through introgression, concluding that although such an origin might be possible, the data then available allowed sister species status between $M$. rheocharis and M. microlepis. In view of the phylogenetic analysis undertaken herein, however, that tentative conclusion will have to be reevaluated.

Material examined. Holotype. MZUSP 40278, adult male, 47.3 mm SL, Brazil, Santa Catarina, município de Praia Grande, rio Faxinalzinho at Mãe dos Homens, near Praia Grande, approximately 29²0’S 1440’W. Paratypes. Collected with holotype: MCP 13616 , 
immatures to adults 3, 24.3-40.8 mm SL; USNM 279878, adults 3, 33.3-47.8 mm SL. Following 3 lots of immature to adult paratypes: Santa Catarina, município de Nova Veneza, rio Jordão at Jordão Alto, approximately 28³6'S 49²8'W, MCP 13617, immatures to adults 83, 21.9-39.0 mm SL; MZUSP 40279, immatures to adults 81, 22.4$42.8 \mathrm{~mm}$ SL; USNM 279879, immatures to adults 89, 22.8-49.0 mm SL. Following lots collected in Santa Catarina, município de Praia Grande, tributary of rio Grande approximately $29^{\circ} 20^{\prime} \mathrm{S} 49^{\circ} 40^{\prime} \mathrm{W}$ : MZUSP 40280, immatures to adults 29, 13.5-38.4 mm SL; USNM 306339, immatures to adults 18, 17.0-40.0 mm SL. Following lots collected in Rio Grande do Sul, município de Osório: MZUSP 40281, adult male, $41.8 \mathrm{~mm}$ SL, arroio das Pedras, approximately 2952'S 50¹9’W; MCP 13613, young adults 7, 27.5-31.3 mm SL, arroio Água Parada, tributary to rio Maquiné, in Maquiné, approximately 2940’S 50¹1’W; MCP 10806, adult male, 39.5 mm SL, município de Torres, tributary of rio Três Forquilhas, Chapéu, approximately 29¹9’S 4944’W. Non-types. Following lots collected from Santa Catarina, município de Praia Grande, arroio Facão, tributary of rio Grande at Mãe dos Homens, 29¹3'59”S 5003'09”W: USNM 326749, immatures to adults 33, SL 30.8-39.8 mm; MCP 21710 immatures 34, 25.8-32.0 mm; MZUSP 53276, immatures to adults 34, SL 24.5-33.5 mm. Following lots, collected from Santa Catarina, município de Praia Grande, rio Canoas, 8 km from Praia Grande in direction of Mãe dos Homens, 29¹4'S 5001'W: USNM 326752 , immatures to adult 3, 28.5-42.4 mm SL; MZUSP 53277, immatures 3, 25.7-30.5 mm SL. Following lot, collected from Santa Catarina, município de Praia Grande, rio Canoas, about $13 \mathrm{~km}$ upstream of Praia Grande, USNM 326751, immature 1, 27.3 mm SL. Following lots all collected from Rio Grande do Sul, município de Três Cachoeiras, rio das Pacas near Morro Azul (discharges into lagoa Jacaré of the rio

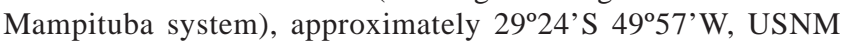
326750, immature 1, 23.8 mm SL; município de Torres, rio dos Mengue between towns of Morro Azul and Rua Nova, a tributary to lagoa Jacaré of the rio Mampituba system, approximately $29^{\circ} 17^{\prime} \mathrm{S} 49^{\circ} 55^{\text {'W }}$, MCP 21711, immature 3, 24.4-27.0 mm SL; Terra de Areia, rio Padre at Itati, a tributary of rio Três Forquilhas, approximately $29^{\circ} 28^{\prime} \mathrm{S}$ 5003’W, USNM 326753 immatures-adults 4, 27.7-31.3 mm SL.

\section{Mimagoniates microlepis (Steindachner, 1877) Figs. 77-79}

Paragoniates microlepis Steindachner, 1877: 33 (type locality: "Bäche in der Nähe von Rio de Janeiro, rio dos Macacos"; although this volume is for the year 1876 and often so cited the date of publication was 1877). - Eigenmann \& Eigenmann, 1891: 57 (listed). - Eigenmann, 1910: 441 (listed). Coalurichthys iporangae Miranda-Ribeiro, 1908 (unpaginated); type locality: "Ribeirão das Pedras, Iporanga”; spelling error for generic name; see generic synonymy for Mimagoniates.

Coelurichthys iporangae Eigenmann, 1910: 428 (listed). Eigenmann 1914: 42 (listed). - Nichols, 1913: 152 (in key to species). - Travassos, 1951: 42 (listed). - P. Miranda Ribeiro, 1955: 390 (listed).

Coelurichthys microlepis Rachow, 1927: 17 (aquarium
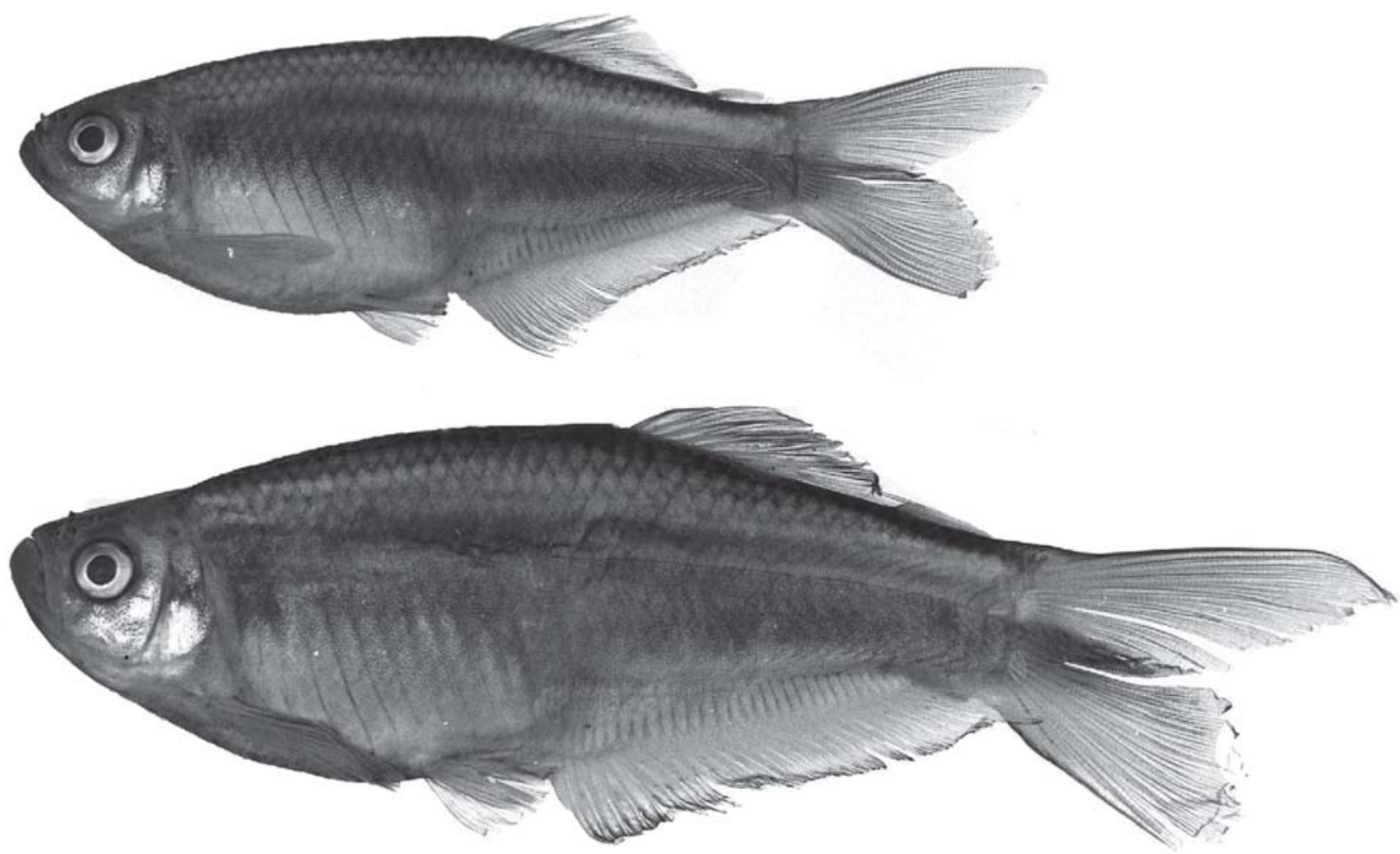

Fig. 77. Mimagoniates microlepis, young adults male below, female above, USNM 254261, 61.2.0 mm and $43.0 \mathrm{~mm}$ SL, respectively, Brazil, São Paulo State, rio Silva on road between Ubatuba and Taubaté. 
description). Rachow in Holly Meinken \& Rachow, 1950a: 755 (in synonymy). - Nelson, 1964a: 62, 63, 68 (anatomy; systematics; courtship behavior). - Géry, 1966: 228, 230 (discussion and in key). - Géry, 1977: 362 (listed in discussion). - Sterba, 1987: 69 (aquarium description).

Mimagoniates microlepis Rachow, 1928: 16 (aquarium description). - Myers, 1928: 120 (listed). - Eigenmann \& Myers, 1929: 491 (redescription; figure). - Innes, 1935: 123 (aquarium description). - Rachow, in Holly, Meinken \& Rachow, 1950a: 755 (aquarium description; synonymy of aquarium literature). - Schultz, 1959: 10 (in part only; listed $M$. tenuis as synonym; of other specimens examined and assigned to M. microlepis, USNM 86296 is M. barberi, USNM 177703 are M. lateralis). - Weitzman \& Fink, 1985: 98, 106 (discussion of caudal pump structure; listed in specimens examined). - Weitzman et al., 1988: 395, 396, 409, 412 (anatomy of caudal gland; discussion of phylogeny and biogeography; figure). - Menezes \& Weitzman, 1990: 381, 386, 388, 389 (phylogeny; in key; anatomy of caudal gland). - Guimarães et al., 1995: 185-189 (cytogenetic studies). Weitzman et al., 1996a: 203-204 (breeding; ecological data; Weitzman et al., 1996b: 195-196, 199-209 (photograph, illustration of tail fin; distribution, ecological data, relationships; courtship behavior). - Malabarba \& Weitzman, 1999: 84 (listed in discussion). - Malabarba \& Weitzman, 2000: 279 (listed in discussion). - López et al., 2002: 59 (listed in type catalog). - Weitzman, 2003: 226 (maximum length; distribution; remarks and references). - Ingenito et al., 2004: 26, 27, 29 (in key; comments on collecting activities and origin of the species in rio Iguaçu) - Sant'Anna et al., 2006: 42-45 (first record in rio Tibagi basin; comments on distribution). - Oyakawa et al., 2006: 152 (photograph; diagnosis; size, distribution; ecological data). - Langeani et al., 2007: 184 (listed in upper rio Paraná). - Torres et al., 2007: 1-7 (chromosomes; molecular data; evolutionary trends). -
Menezes et al., 2007: 125 (photograph; distribution; systematic status; synonyms; ecology; conservation). Menezes, 2007: 39 (listed in catalog; distribution). - Menezes et al., 2008: 37-40, 43-45 (photograph; distribution; molecular analysis; discussion of relationships and biogeography).

Coelurichthys lateralis Myers in Eigenmann \& Myers, 1929: 491, 492 (type examined and erroneously referred it to $M$. microlepis). - Rachow in Holly, Meinken \& Rachow, 1950a: 755 (referred species to M. microlepis following Myers, in Eigenmann \& Myers, 1929: 491, 492. - Schultz, 1959: 11 (followed Myers, in Eigenmann and Myers, 1929: 491, 492). - Nelson, 1964a: 65 (in part; found female type of C. lateralis difficult to identify and could not decide whether it was $C$. microlepis or $C$. tenuis but if latter, $C$. lateralis would have priority because of page precedence).

Coelurichthys tenuis Myers, in Eigenmann \& Myers, 1929: 491, 492 (type examined and erroneously referred it to $M$. microlepis). - Rachow, in Holly Meinken \& Rachow, 1950a: 755 (followed Myers, in Eigenmann \& Myers 1929: 491, 492 in referring this nominal species to M. microlepis).

Mimagoniates inequalis Schultz, 1959: 63 (in part only, one specimen of $M$. microlepis, USNM 177704, was misidentified as $M$. inequalis).

Mimagoniates cf. microlepis Géry, 1964: 6, (discussion; osteology of caudal and anal fins).

Mimagoniates sp. C, Weitzman et al., 1988: 411-412 (osteology of caudal fin).

Diagnosis. Mimagoniates microlepis can be distinguished from all the other species of Mimagoniates except $M$. rheocharis by the presence of a fully developed caudal-fin ray pump and hooks on some principal caudal-fin rays. In addition to having caudal-fin hooks spiny (vs. sturdy in $M$. rheocharis), M. microlepis differs from M. rheocharis by the number of horizontal scale rows between dorsal- and anal-fin

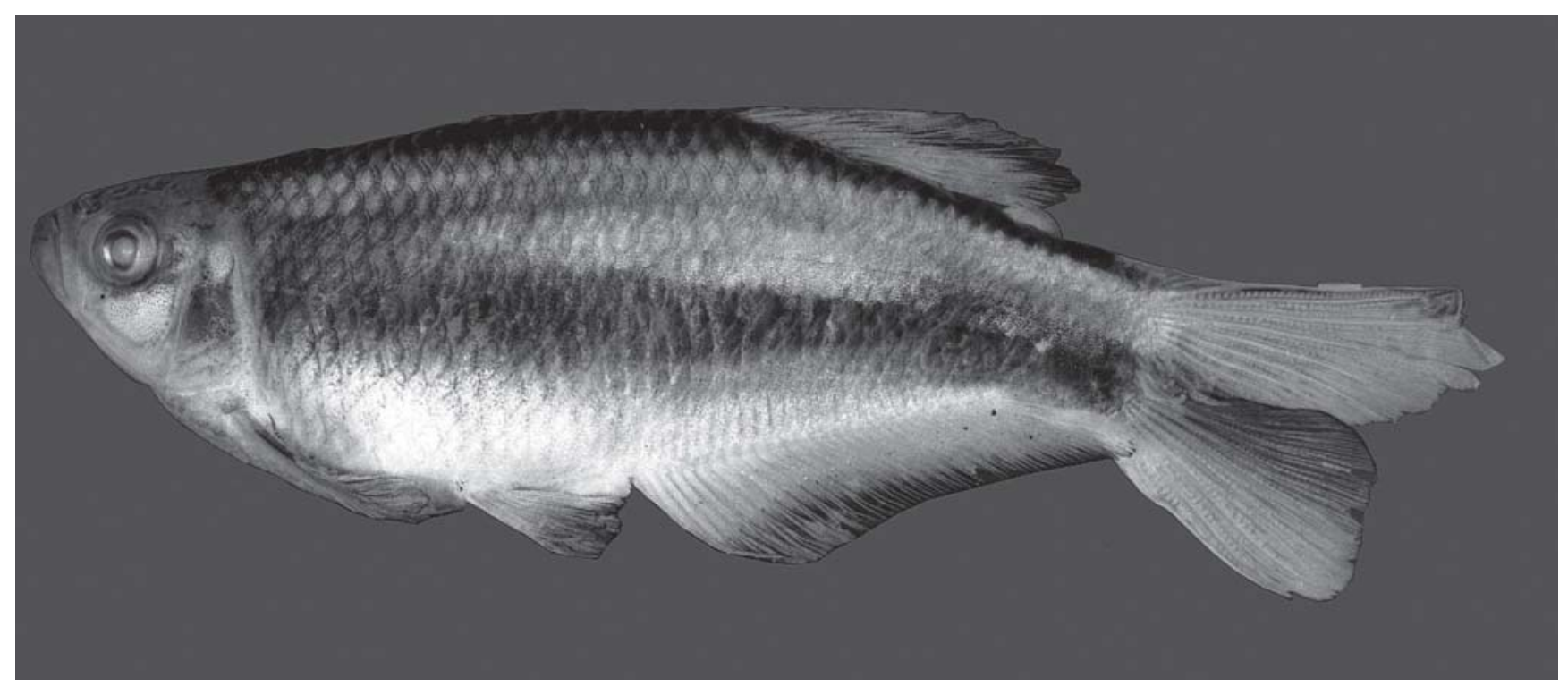

Fig. 78. Mimagoniates microlepis, large adult male, USNM 249888, 53.3 mm SL, Brazil, São Paulo State, rio Biguá near Biguá. 


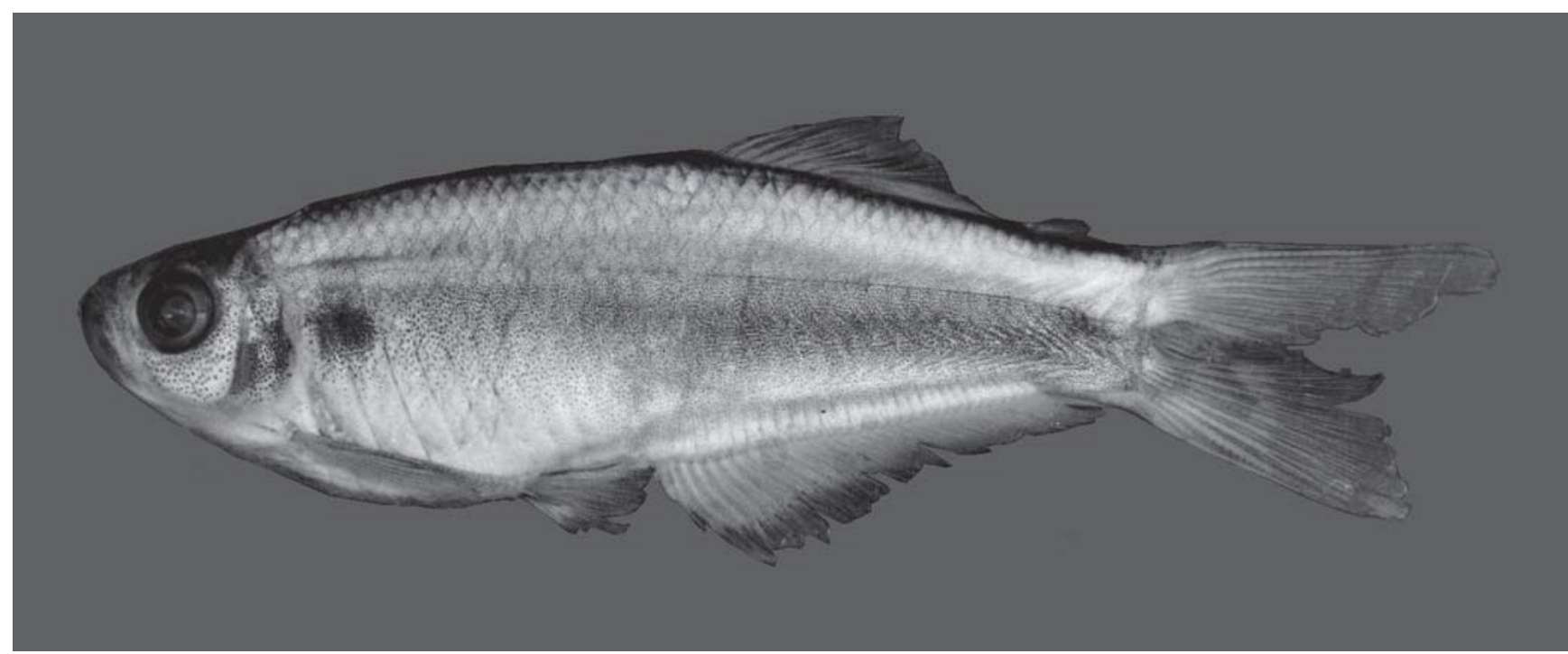

Fig. 79. Mimagoniates microlepis, adult male, MZUSP 14668, 40.7 mm SL, Rio de Janeiro State, rio Guapiaçu, Cachoeiras de Macacu.

origins (15-18 vs. 17-22 for M. rheocharis), scales around caudal peduncle (15-18 vs. 19-23 for M. rheocharis), and coloration as discussed in the diagnosis of $M$. rheocharis.

Description. Table 12 presents morphometrics of the lectotype, paralectotype and topotypes. Except where noted, the entire description refers to the population sample represented by specimens from rio Macacu, the type locality or adjacent tributaries flowing into this river. These collections were treated statistically as one population sample in an attempt to represent the species. Variations of meristic and morphometric data within the range of $M$. microlepis are discussed where appropriate.

Body compressed, relatively deep, especially near dorsalfin origin; body deepest at vertical through anal-fin origin. Predorsal body profile relatively arched in adult males, less so in adult females and immatures which have predorsal profile gently convex. Body profile elevated at dorsal-fin origin, less so in females and juveniles. Dorsal profile of body nearly straight along dorsal-fin base to adipose fin. Body profile posterior to adipose fin somewhat concave dorsal to caudal

Table 12. Morphometrics of Mimagoniates microlepis. Standard length is expressed in mm; measurements through bony head length are percentages of standard length; the last four entries are percentages head length. A plus sign under the abbreviation dif indicates there is a significant statistical difference between the males and females in the particular character indicated. Specimens are from rio Macacu or some of its tributaries: NMW 56534 (lectotype), USNM 249896, MZUSP 14667, MZUSP 14668 and MZUSP 14669. SD = Standard deviation.

\begin{tabular}{|c|c|c|c|c|c|c|c|c|c|c|}
\hline \multirow{2}{*}{ Characters } & \multicolumn{5}{|c|}{ Males } & \multicolumn{4}{|c|}{ Females and juveniles } & \multirow[b]{2}{*}{ dif. } \\
\hline & Holotype & $\mathrm{N}$ & Range & Mean & SD & $\mathrm{N}$ & Range & Mean & SD & \\
\hline Standard length & 47.5 & 28 & $30.0-47.5$ & 31.4 & & 15 & $19.0-30.4$ & 24.0 & & \\
\hline Depth at dorsal-fin origin & 30.9 & 28 & 24.5-30.9 & 26.5 & 1.6 & 15 & $21.2-26.6$ & 24.4 & 1.7 & + \\
\hline Snout to dorsal-fin origin & 60.2 & 28 & 57.5-65.0 & 61.6 & 1.3 & 15 & $59.4-63.8$ & 61.3 & 1.3 & - \\
\hline Snout to pectoral-fin origin & 26.5 & 28 & 23.3-26.7 & 25.3 & 1.0 & 15 & 23.4-26.4 & 24.8 & 1.1 & - \\
\hline Snout to pelvic-fin origin & 43.4 & 28 & $42.4-45.6$ & 44.3 & 0.8 & 15 & $40.1-44.7$ & 43.3 & 1.5 & - \\
\hline Snout to anal-fin origin & 56.8 & 28 & $53.0-58.6$ & 56.5 & 1.3 & 15 & $54.2-58.4$ & 56.1 & 1.4 & - \\
\hline Caudal peduncle depth & 14.7 & 28 & $11.4-14.7$ & 13.2 & 0.9 & 15 & 09.4-13.9 & 11.2 & 1.2 & + \\
\hline Caudal peduncle length & 9.3 & 28 & $06.2-09.2$ & 07.8 & 0.8 & 15 & 07.8-09.1 & 08.4 & 0.4 & - \\
\hline Pectoral-fin length & 21.7 & 28 & $20.4-25.8$ & 23.2 & 1.4 & 15 & $20.0-24.5$ & 21.8 & 1.3 & - \\
\hline Pelvic-fin length & 13.9 & 28 & 12.6-16.9 & 14.8 & 1.1 & 15 & $10.5-14.6$ & 12.6 & 1.2 & + \\
\hline Dorsal-fin base length & 14.1 & 28 & $12.0-15.9$ & 14.2 & 0.9 & 15 & $10.5-14.2$ & 12.4 & 1.0 & - \\
\hline Dorsal-fin height & 38.3 & 27 & $25.2-38.3$ & 31.3 & 3.2 & 15 & $19.1-24.4$ & 21.8 & 1.2 & + \\
\hline Anal-fin base length & 36.4 & 28 & $35.7-40.0$ & 37.2 & 1.2 & 15 & $35.1-39.4$ & 36.9 & 1.3 & - \\
\hline Anal-fin lobe length & 30.1 & 26 & $16.0-20.4$ & 18.4 & 1.5 & 15 & $17.7-21.0$ & 19.1 & 0.9 & - \\
\hline Eye to dorsal-fin origin & 51.2 & 28 & $45.8-51.2$ & 49.0 & 1.3 & 15 & 46.1-50.3 & 47.8 & 1.0 & - \\
\hline Dorsal-fin origin to caudal-fin base & 42.9 & 28 & $37.4-44.5$ & 41.2 & 1.8 & 15 & $38.0-42.7$ & 40.2 & 1.3 & - \\
\hline Bony head length & 23.4 & 28 & $22.2-26.3$ & 24.5 & 1.0 & 15 & $22.8-25.4$ & 24.0 & 0.8 & - \\
\hline Horizontal eye diameter & 34.2 & 28 & $34.2-41.6$ & 37.4 & 2.3 & 15 & $34.0-41.6$ & 38.0 & 2.7 & - \\
\hline Snout length & 24.3 & 27 & $21.4-25.2$ & 23.6 & 1.1 & 15 & $21.2-25.0$ & 22.7 & 1.1 & - \\
\hline Least interorbital width & 34.2 & 28 & 32.0-36.6 & 34.3 & 1.4 & 15 & 32.7-36.9 & 35.2 & 1.3 & - \\
\hline Upper jaw length & 45.9 & 27 & 41.9-46.8 & 44.6 & 1.2 & 15 & $41.5-46.8$ & 44.1 & 1.5 & - \\
\hline
\end{tabular}


peduncle. Dorsal-fin origin nearer to caudal-fin base than to snout tip. Ventral profile of body strongly convex in adult males from tip of lower jaw to origin of pelvic fin, less strongly convex in females and juveniles. Abdominal profile in adult males slightly concave to anal-fin origin, straight or nearly so in females and juveniles. Body profile along anal-fin base in males slightly concave along base of anterior lobe of anal fin; straight along base of remainder of fin in males and along entire anal-fin base in females and juveniles. Ventral profile of caudal peduncle convex in adult males due to strong development of anterior 5 or 6 procurrent ventral caudal-fin rays included in that profile; slightly concave or nearly straight in females and juveniles.

Lower jaw protruding, slightly beyond upper jaw. Lower jaw of adult males thick and heavy compared to that of females and juveniles. Mouth angled posteroventrally. Maxilla long, extending to point ventral to horizontal through ventral border of eye. Maxilla extends posteriorly to a point anterior to vertical line drawn through anterior border of pupil.

Dorsal-fin rays ii, 8 in all specimens, $n=41$; posterior ray not split to its base and counted as 1 ray. Anal-fin unbranched rays iv or v, usually iv, branched rays 26-31 (27), 28.2, $n=42$; posterior ray split to its base and counted as 1 ray. Anal fin with moderately developed lobe anteriorly (Figs. 77-79 and 81); lobe includes last unbranched ray and first 5 branched rays. Anal fin of sexually mature males with bilateral hooks, 13 , usually 1 on each side, on posterior most unbranched ray (Fig. 81). Usually anterior 7-8 branched fin rays with bilateral hooks, 1 set for each ray. Pectoral-fin unbranched ray i in all specimens, branched rays 8-11 (9), 9.7, $n=42$. Posterior tip of

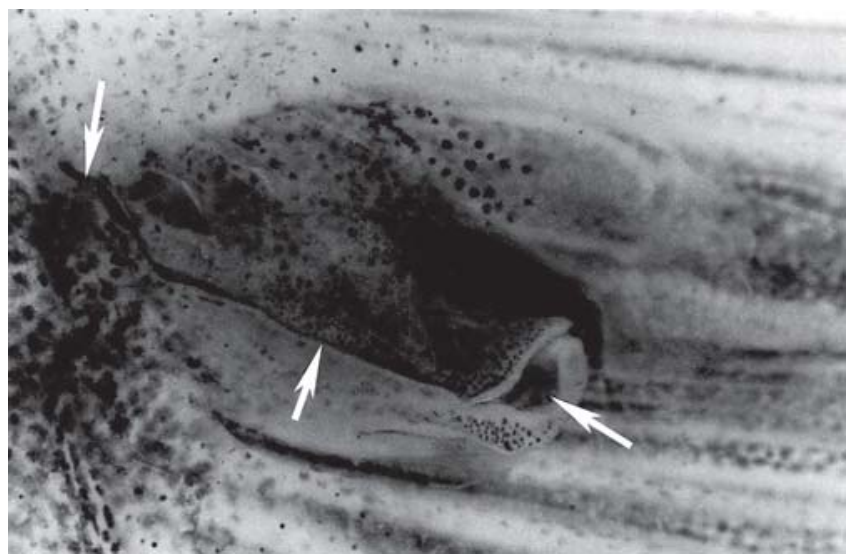

Fig. 80. Mimagoniates microlepis, male, USNM 279876, 51.7 mm SL; central basal region of caudal fin adjacent to caudal peduncle (at left), lateral view, left side, anterior at right. Illustrates external features of caudal organ including fin-ray pump chamber. Arrow at left indicates anterior intake opening, middle arrow points to lateral slit in pump chamber, and arrow at right designates posterior exit opening. Modified dorsal lobe caudal-fin squamations translucent and difficult to see but represented by light circular "ghost" images over the dorsal surface of pump chamber and posterior to chamber. Modified from Menezes \& weitzman (1990). first pectoral fin extends posteriorly slightly beyond origin of pelvic fin. Pelvic fin rays 7 in all specimens. Pelvic fin with first ray branched in adult males and females (Fig. 83), unbranched in juveniles of both sexes. Sexually mature, large adult males with over 200 hooks on each pelvic fin distributed as shown in Figs. 83 and 84.

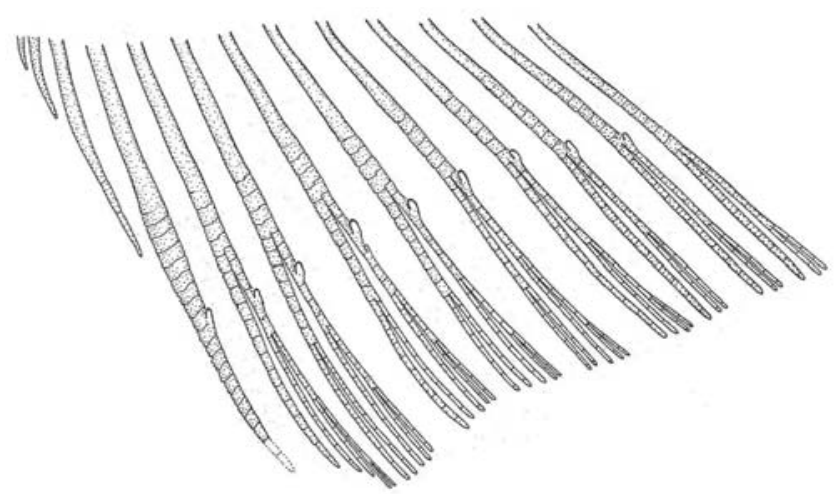

Fig. 81. Mimagoniates microlepis, large adult male, USNM 249876, $59.3 \mathrm{~mm}$ SL; anterior 13 anal-fin rays, lateral view, left side.

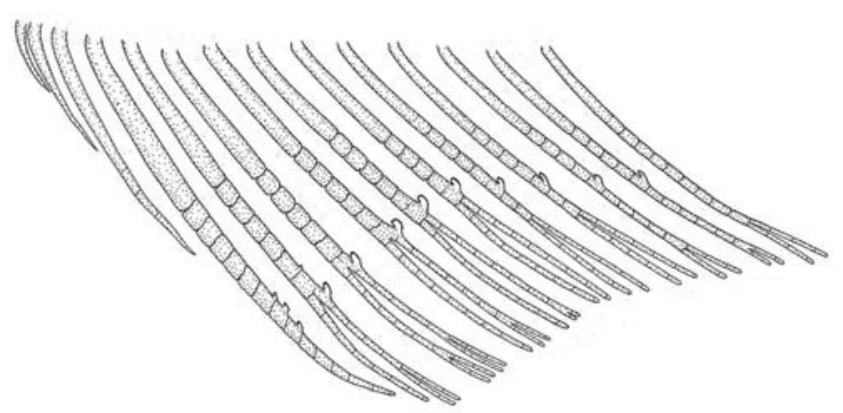

Fig. 82. Mimagoniates microlepis, adult male, USNM 249885, $41.2 \mathrm{~mm}$ SL; anterior 14 anal-fin rays, lateral view, left side.

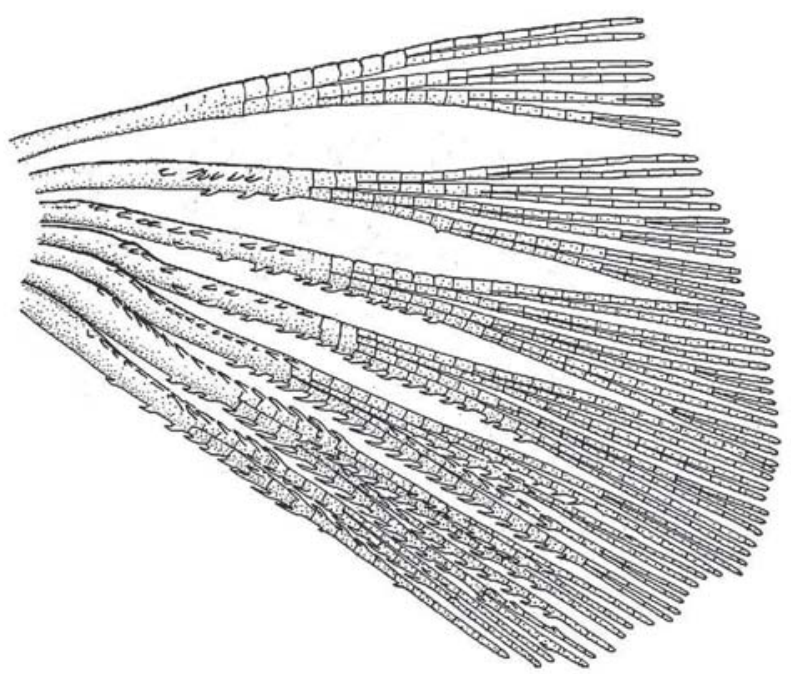

Fig. 83. Mimagoniates microlepis, large adult male, USNM 249876, 59.3 mm SL; pelvic-fin rays, ventral view, left side. 


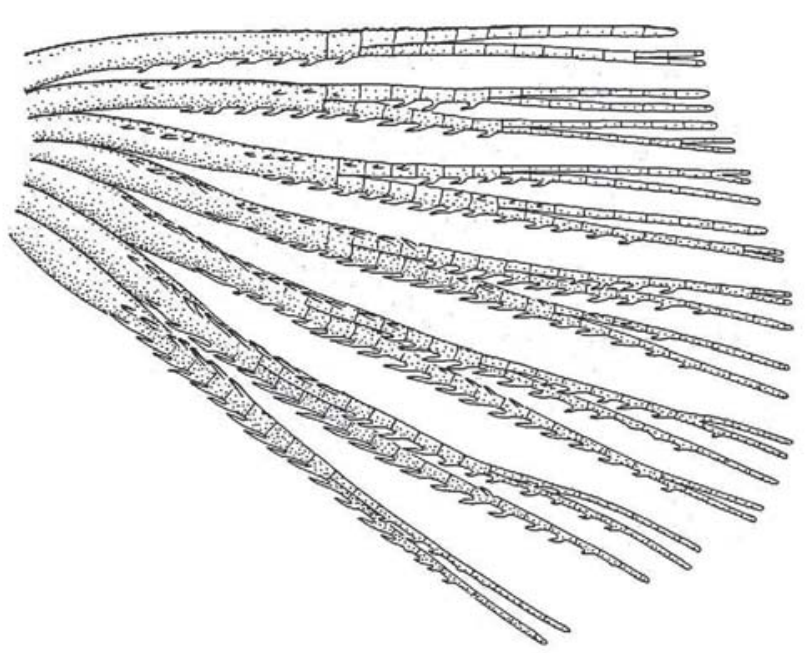

Fig. 84. Mimagoniates microlepis, adult male, USNM 249885, $41.2 \mathrm{~mm}$ SL; pelvic-fin rays, ventral view, left side. All rays with fewer branches compared to those of large adult male in Fig. 83.
Principal caudal-fin ray count 10/9 in all specimens, $n=42$. Fin rays modified in association with caudal pheromone pump as in Fig. 85. Caudal-fin rays 8 to 12 with small bony hooks.

Scales cycloid, with few radii along posterior border. Terminal scale of modified caudal-fin series without exaggerated radii (Fig. 85 ).

Lateral line incomplete, perforated scales $=6-9(6), 7.1, \mathrm{n}=$ 23. Lateral series scales $40-46$ (43), $42.7, n=21$. Predorsal scales 21-24 (23), 22.9, $\mathrm{n}=24$. Scale rows between dorsal- and anal-fin origins $13-16(14), 14.5, n=34$. Scale rows around caudal peduncle 15-17 (16), 16.3, $\mathrm{n}=12$.

Premaxillary teeth in 2 irregular almost undistinguishable rows and summary count for teeth on left premaxilla are given as a single count (Fig. 86). Larger and smaller teeth tricuspid in all large specimens, sometimes in smaller specimens small teeth bicuspid or conical. Total count premaxillary teeth 7-11 (9), 8.8, $\mathrm{n}=41$. Maxillary teeth 3-7 (5), 4.09, larger specimens usually with more teeth counts, $n=$ 41. All maxillary teeth tricuspid in large specimens; small specimens with posterior maxillary teeth often conical (Fig.

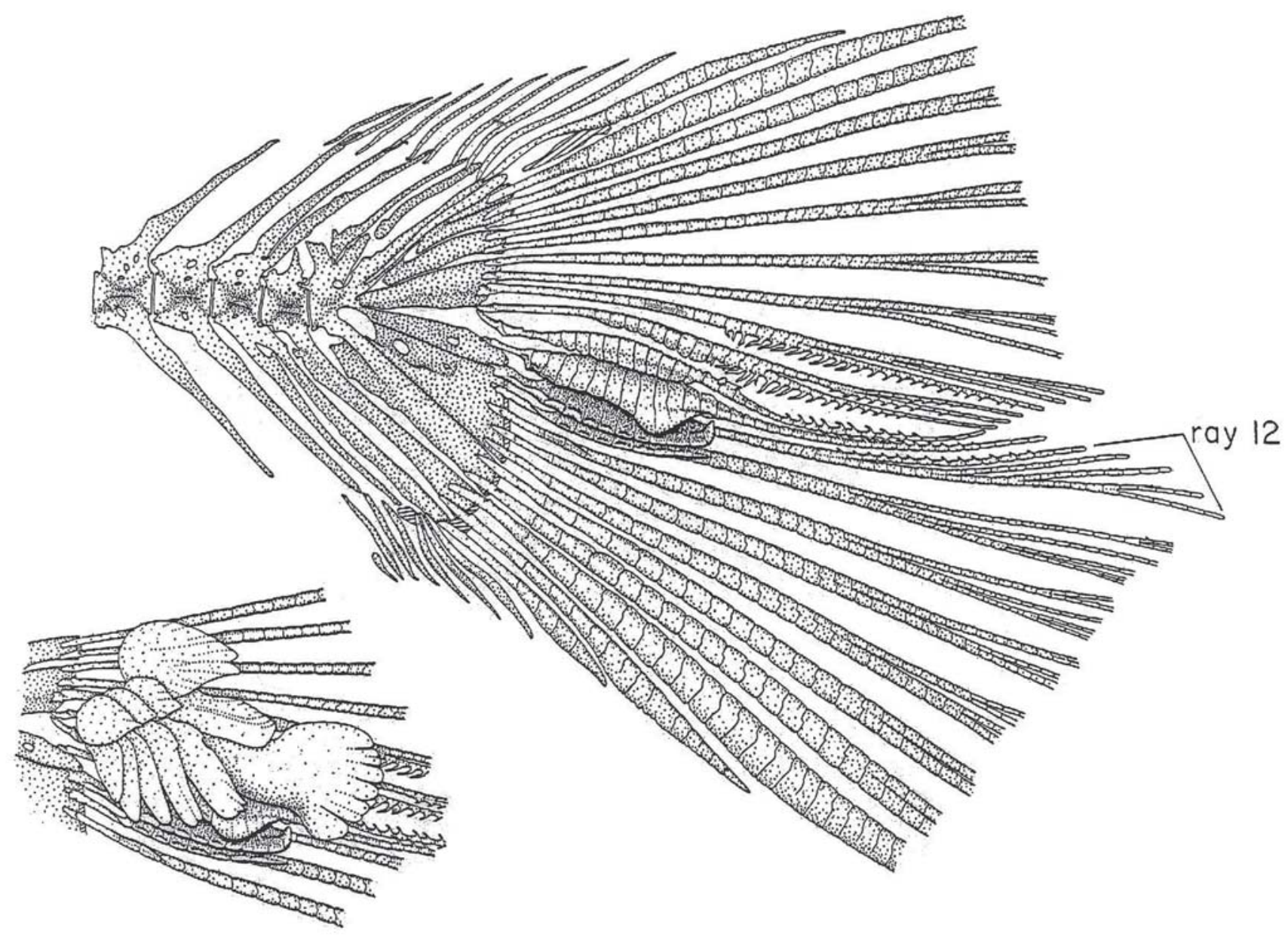

Fig. 85. Mimagoniates microlepis, adult male, USNM 236089, $45.3 \mathrm{~mm}$ SL; osteology of caudal skeleton and caudal-fin squamation (lower left), lateral view, left side. Principal caudal ray 12 indicated. Relationship of modified dorsal lobe caudal-fin squamation to caudal gland shown in inset at lower left. Distal regions of ventral and posterior scales and their epidermis form flap partly covering intake openings of pump chamber. Modified from Menezes et al. (1988). 
86). Dentary with 4 large anterior tricuspid teeth, followed by smaller posterior teeth 4-11 (9), 7.5, almost always more teeth in largest specimens; anterior small dentary teeth of posterior series tricuspid, posterior ones conical, $n=41$ (Fig. 86). Maxillary and dentary teeth shaped much like premaxillary teeth.

Vertebrae 37-39 (38), 38.2, $n=42$. Dorsal limb gill rakers 57 (6), 6.2, $n=41$; ventral limb gill rakers 10-12 (12), 11.2, $n=41$. Branchiostegal rays 4, in 11 cleared and stained specimens, 3 rays originating on anterior ceratohyal and 1 ray from posterior ceratohyal.

Color in alcohol. See Figs. 77-79 for preserved color pattern of males and females. Some variation occurs in color pattern of population samples from geographically isolated areas within species range. Following basic color pattern of specimens from the type locality characteristic of all specimens available. Body pale to medium brown, pale yellowish-brown ventrally, much darker dorsally. Humeral spot slightly vertically elongate, in both sexes, obscured by dark lateral stripe in some specimens. Dark lateral body stripe somewhat diffuse anteriorly, darker posteriorly, but uniformly dark in some specimens of both sexes. Stripe extending from humeral spot posteriorly onto dorsal region of ventral caudal-fin lobe and
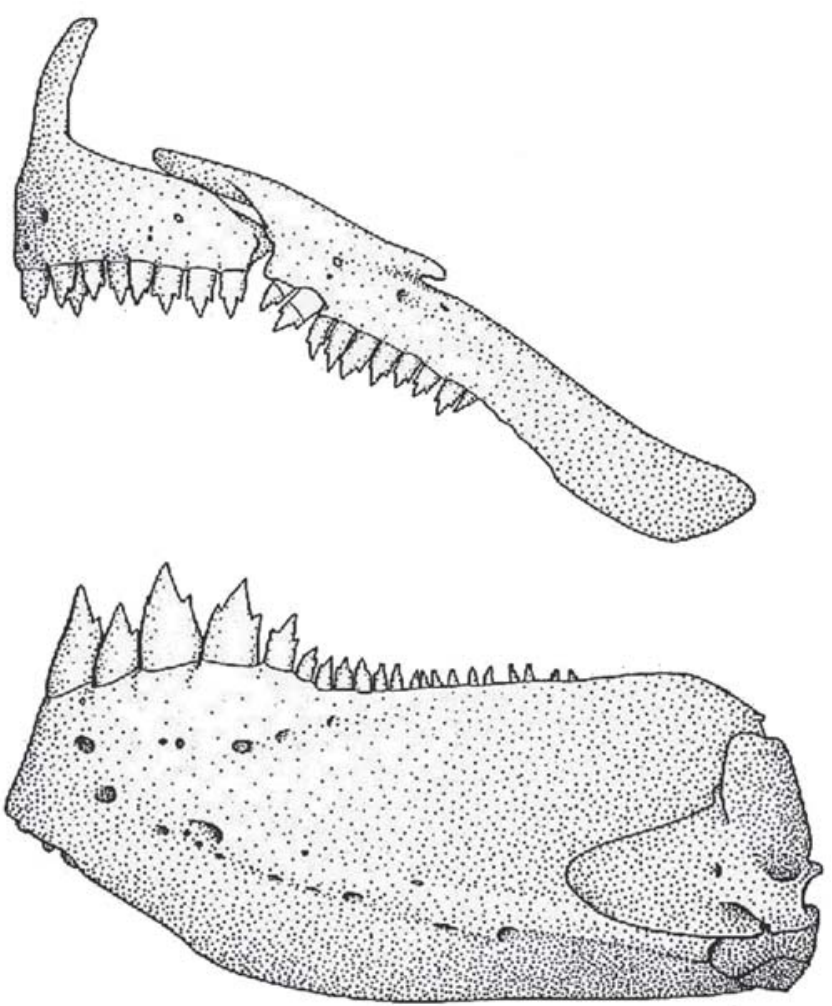

Fig. 86. Mimagoniates microlepis, adult male, USNM 249876, $59.3 \mathrm{~mm}$ SL; jaws and dentition, lateral view, right side, anterior at right. Compare number of maxillary teeth (10) in this specimen with that in Fig. 87 (6). Number of maxillary teeth varies considerably in specimens depending on their standard length. ventral portion of dorsal caudal-fin lobe. Lateral stripe extends over all caudal gland structures. Stripe especially dark on principal rays 10, 11 and 12 , less so on ray 13 . Remainder of caudal fin dusky due to presence of scattered dark chromatophores. Dorsal border of first principal caudal-fin ray and ventral border of nineteenth principal caudal-fin ray black. Middorsal body surface black, forming narrow stripe extending from supraoccipital region to base of dorsal procurrent rays of caudal fin. Indistinct narrow dark stripe between dorsal black stripe and lateral stripe posteriorly from dorsal-fin origin to caudal base. Remainder of dorsal body surface ventral to lateral body stripe pale brown.

Pectoral and pelvic fins dark, dorsal and anal dusky with scattered dark chromatophores along fin rays and membranes. Anal fin with dark elongate stripe running length of fin. Stripe width about one-third height of anal fin anteriorly and about one-fourth fin's height posteriorly; bordering edge of fin from sixth or seventh branched rays to posterior tip of last rays. Stripe of nearly uniform width throughout its length. Stripe somewhat darker anteriorly in sexually mature males, especially dorsal to relatively hyaline anterior tip of anal-fin lobe. Dorsalfin with horizontal dark stripe in adult males and females extending posteriorly from about mid-length of anterior elongate unbranched ray to posterior tips of two terminal dorsal-

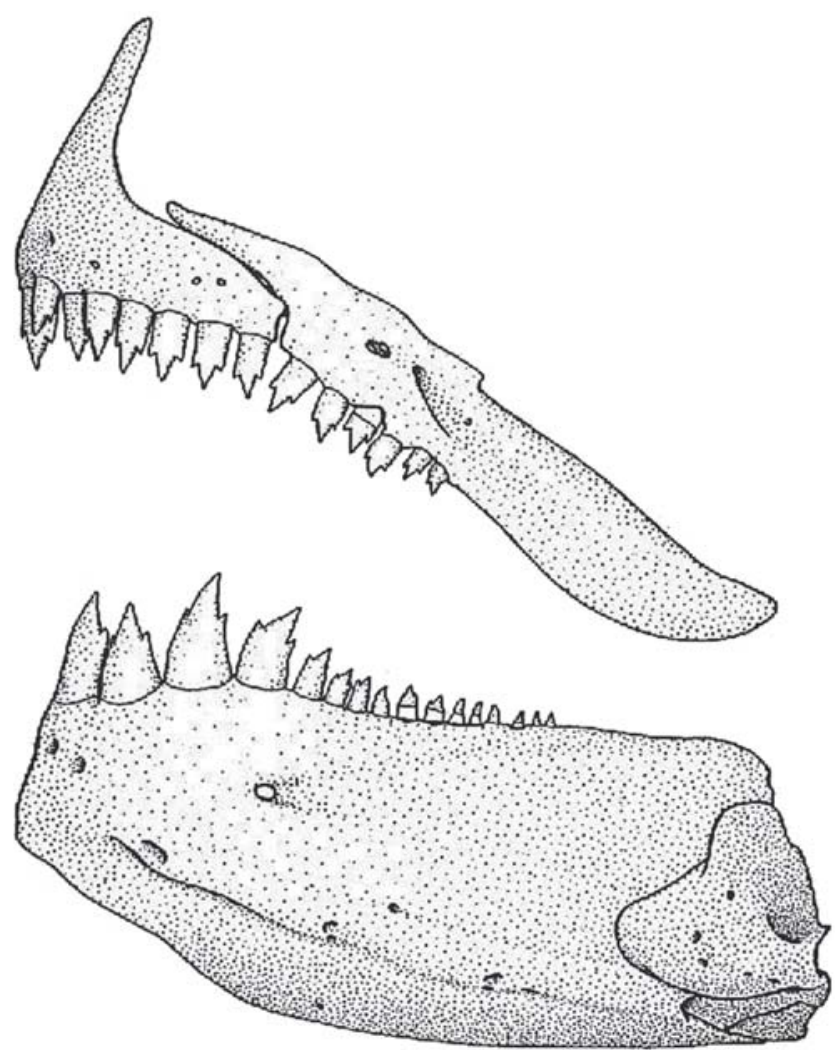

Fig. 87. Mimagoniates microlepis, adult male, USNM 249885, $41.2 \mathrm{~mm}$ SL; jaws and dentition, lateral view, right side, anterior at right. 
fin rays. Stripe usually narrow, less than one-eighth maximum height of dorsal fin. Width and intensity of stripe variable depending on sex and sexual maturity. Preserved males sometimes with anterior portion of stripe diffuse. Adipose fin dusky with scattered dark chromatophores.

Head light to dark brown around mouth and on dorsal surface of snout, between eyes, dorsal portion of cranium and nape. Tip of lower jaw light to dark brown. Portion of head posterior to infraorbitals and extending ventrally from parietal region across dorsal opercular region dark brown. Dark area continues ventrally across posterior region of opercle to just reach interopercle and looks similar in form as humeral spot. Iris dark brown, dorsal to pupil and silvery elsewhere. Infraorbitals silvery where guanine preserved, pale yellowish brown when guanine absent. Dark brown chromatophores scattered evenly through circumorbital area. Anterior area of opercle, all of preopercle, and branchiostegal rays silvery or pale brown, without much dark brown pigment.

Color in life. Life colors described here taken from a $35 \mathrm{~mm}$ color slide of an adult male collected in rio Sagrado system photographed just after capture from clear slightly turbid water stream, baía de Guaratuba, Paraná. Sides of body pale silvery blue. Broad lateral body stripe somewhat deeper silvery blue from humeral spot to caudal peduncle. Just dorsal to silvery blue color of body sides, dorsum with narrow dark brown line extending from parietal region of head to caudal peduncle, black with blue pigment on procurrent rays. Lateral portion of dorsum between narrow brown line and lateral body stripe light brown. Lower jaw and upper part of head above eye dark with blue pigment. Infraorbitals and ventral part of preopercle and opercle silvery white with scattered blue chromatophores. Dorsal part of preopercle and opercle dark with scattered blue and black chromatophores. Ventral portion of head from about vertical through anterior border of eye and abdominal region yellowish. Lower part of body ventral to lateral stripe silvery with scattered blue and yellow chromatophores. Basal part of anal fin yellow with scattered blue chromatophores. Caudal fin hyaline with blue pigmentation especially evident on middle caudal-fin rays. Ventral most unbranched principal caudal-fin ray distally black. Remainder of black pigment of caudal fin in preserved specimens. Anal fin with distal portion of fin rays posterior to anterior anal-fin lobe dark obscured by blue pigmentation, forming stripe along margin of fin. Distal region of anterior anal-fin lobe yellow, proximally bordered by black pigment mixed with yellow and blue. Approximately distal one-half of pelvic fin yellow; remaining proximal portion of fin hyaline. Distal one-half of pectoral fins yellow, proximal half hyaline. Dorsal fin hyaline distal and proximal to longitudinal black longitudinal stripe partly obscured by yellow and blue pigmentation.

Sexual dimorphism. Females lack a caudal pheromone pump organ and pelvic-fin and anal-fin hooks described above for males. Life colors of females more subdued than that of sexually mature males. Among the characters showing significant differences between males and females as indicated in Table 12, only dorsal-fin height proved to be statistically different through regression analysis. Figure 88 clearly shows a significant difference expressed by the slopes of males and females indicating a divergence at all sizes.

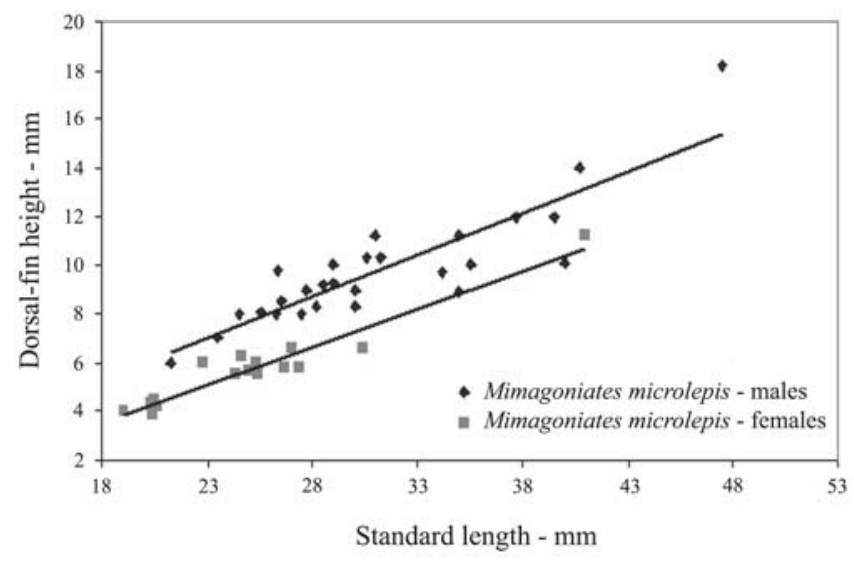

Fig. 88. Mimagoniates microlepis. Dorsal-fin height as function of SL by sex.

Distribution. Mimagoniates microlepis is widely distributed in the coastal area from southern Bahia to northern Rio Grande do Sul and also in the upper rio Iguaçu and rio Tibagi, upper rio Paraná basin, Brazil. See figure 3 in Menezes et al. (2008).

Ecology. Weitzman et al. (1988: 413) mentioned that $M$. microlepis occurs in clear running waters of small to large streams and is quite common and most abundant in forested areas near the shore. Subsequently Menezes \& Weitzman (1990: 423) pointed out that it is rarely found in black acid waters. More recent collections of this species obtained from eastern and southeastern Brazilian coasts, however, indicated that it is more common in blackwaters than previously thought. It has been recently collected in small black water streams with substrate consisting of clay, rocks and sand as well as in clear water streams in Santa Catarina. In most other places both in eastern and southern Brazil, M. microlepis was caught in slow moving clear water streams and small ponds, even in areas where the original Mata Atlântica vegetation was removed. In the small streams the water was cool and rocks, sand, mud and twigs fallen from isolated trees were usually found on the bottom.

Data from Costa (1987) indicate that M. microlepis lives near the surface and feeds mostly on terrestrial arthropods. Sabino \& Castro (1990) found that it is primarily insectivorous and that $73.6 \%$ of its diet consists of items that fall into the water, especially insects (63.15\%) and arachnids (10.5\%). Essentially the same results were obtained by Lampert et al. (2003) who concluded that M. microlepis is insectivorous regardless of size and sex.

Remarks. The discussion of meristic and morphometric differences as well as possible hybrid origins involving $M$. 
microlepis, M. rheocharis and M. inequalis in Menezes \& Weitzman (1990: 416-421) are not repeated here. For further comments on relationships of $M$. microlepis see the "Phylogeny" section.

Anal-fin branched ray counts, number of scales (horizontal scale rows on body, horizontal scale rows around caudal peduncle, lateral-series scales and predorsal scales), and number of vertebrae of Mimagoniates microlepis showed significant differences among population samples of the species (Figs. 89 and 90). For the purpose of comparison, the samples were grouped within the biogeographical coastal subregions defined by Menezes (1988: 300). Comparing only samples included in the North Coastal Subregion with the samples included in the more southern upland areas of Paraná the respective ranges and medians are significantly different, with very little overlap in some cases. However, the same values for the intermediate samples included in the South Coastal and in the two Central Coastal subregions bridge the gap. Thus there is a pattern of latitudinal variation of characters than sharp differences that would justify the recognition of more than one species. The recent discovery of specimens identified as M. microlepis from the rio Tibagi basin (Sant'Anna et al., 2006) flowing through the upper Paraná basin demonstrates that it is more widespread than previously indicated. The distribution of some isolated populations of $M$. microlepis is discussed by Menezes et al. (2008). Until a more detailed analysis of character variation within the range of $M$. microlepis can be performed, we prefer for the moment to consider it a widespread species represented by isolated populations.

No date of collection of the lectotype of M. microlepis, NMW 56534, was provided, but NMW catalog cites the collector as Steindachner and the date of receipt of specimens as 1874. Likely the specimens originated near town of Macacu (also called Cachoeiras de Macacu, approximately $22^{\circ} 26^{\prime} \mathrm{S}$ $42^{\circ} 49^{\prime} W$ ) in 1874 by Steindachner during Hassler Expedition, 1871-1872. Our observations indicate that species frequently occurs in small tributaries of rio Macacu and along shores of main river in emergent vegetation.

The holotype of Coelurichthys iporangae, USNM 92955 is apparently identical to that in photograph published by Miranda Ribeiro (1908: unpaginated). Both the specimen and photograph display the same bent body shape, the same wound to the upper portion of the abdominal cavity on the left body side. Miranda-Ribeiro's original description is in the singular as though he was describing one specimen. However the number of specimens he had at hand is in some question. In the introduction to his study Miranda Ribeiro (1908) states "Both the Museu de São Paulo and the Museu Nacional have the material evidences of these studies". We found a second specimen, MZUSP 408, $42.7 \mathrm{~mm}$ SL, collected by Krone from the ribeirão das Pedras, Iporanga, a tributary of the rio Ribeira de Iguape, São Paulo. No date of collection is given for this fish but we strongly suspect this specimen may have been collected with the type and probably sent to the Museu Paulista by Ricardo Krone, and subsequently transferred to the Departamento de Zoologia (now the Museu de Zoologia), Universidade de São Paulo. Miranda Ribeiro perhaps saw the specimen now at MZUSP but used only the specimen sent to the Museu Nacional, Rio de Janeiro in his original description. There is no absolute evidence that A. Miranda Ribeiro ever saw the MZUSP specimen. In any case this specimen appears not to have been previously discussed in the ichthyological systematic literature.

The fish here considered as holotype of $C$. iporangae, USNM 92955, cataloged on 11 Aug. 1933 as part of a collection donated to the USNM by George S. Myers. The fish had been obtained from the Museu Nacional, Rio de Janeiro by

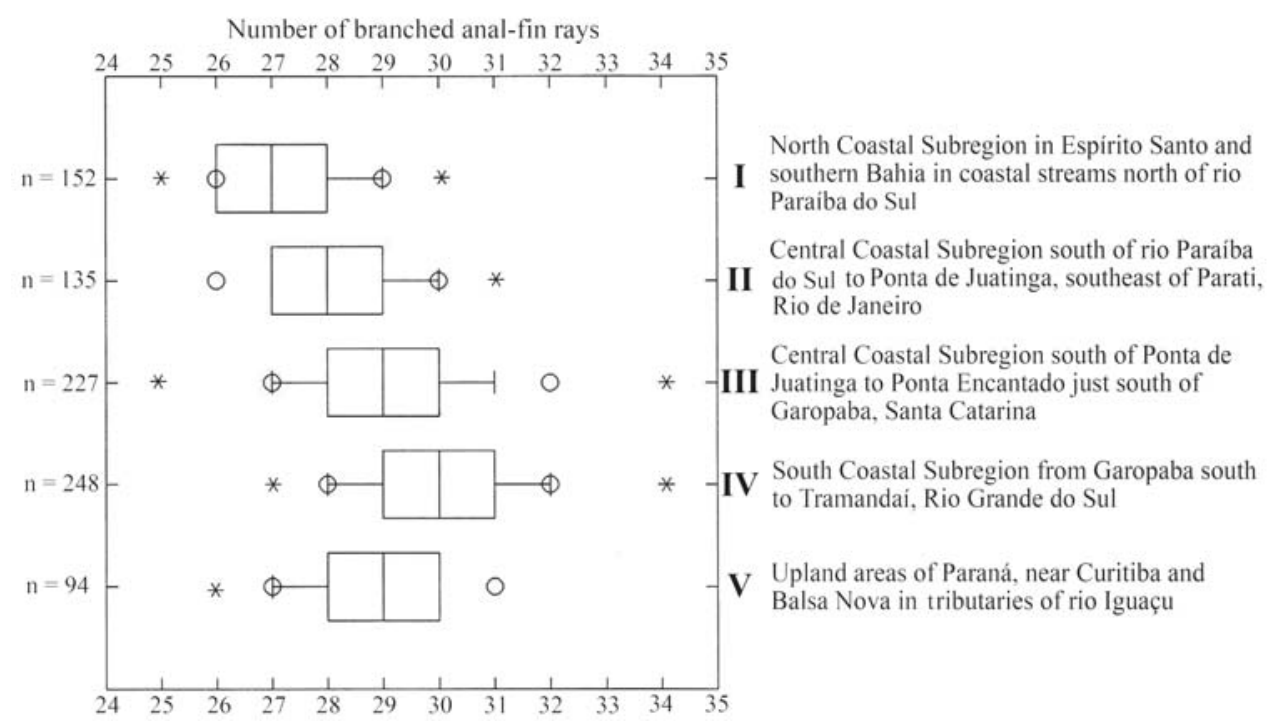

Fig. 89. Comparative plots of the number of branched anal-fin rays for population samples of Mimagoniates microlepis within range of species expressed by Tukey box plots based on percentiles. 

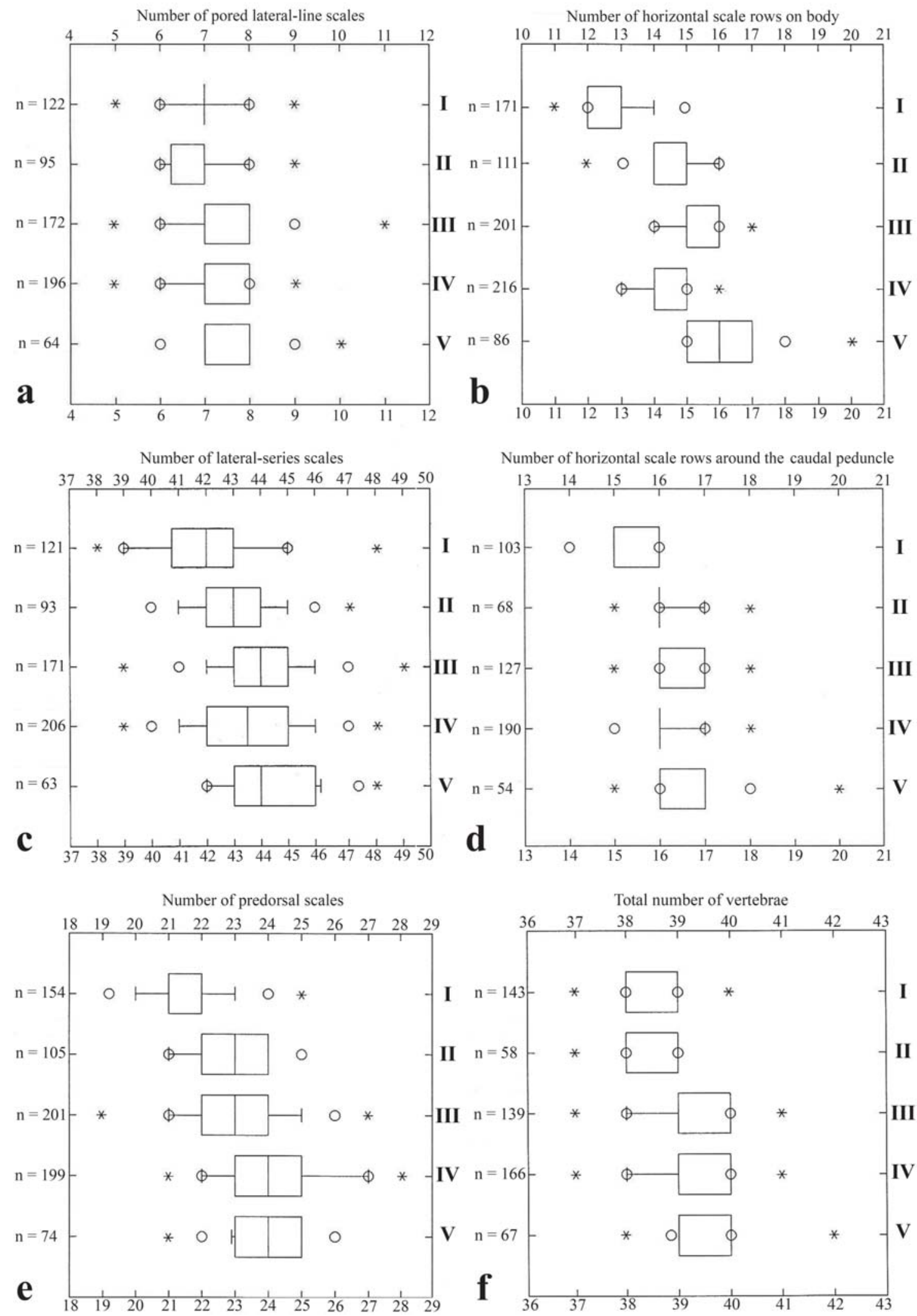

Fig. 90. Comparative plots of (a) Number of pored lateral-line scales; (b) Number of horizontal scale rows on body; (c) Number of lateral-series scales; (d) Number of horizontal scale rows around the caudal peduncle; (e) Number of predorsal scales; (f) Total number of vertebrae for samples of Mimagoniates microlepis within range of species expressed by Tukey box plots. For I, II, III, IV and V locations, see full legends at Fig. 89. 
Eigenmann for his studies. In the USNM accession papers, (accession 124667), Myers listed this fish as a paratype and noted that he had earlier received the specimen from Eigenmann on exchange. Myers erroneously listed the collector as Alipio de Miranda Ribeiro rather than Ricardo Krone. This specimen was in turn listed by Eigenmann \& Myers (1929: 491) as "Mus. Nac. Rio de Janeiro, type, number of specimens 1, size $51 \mathrm{~mm}$, locality Iporanga, collector Haseman". The references to Haseman and Miranda Ribeiro as collectors are clearly errors according to Myers in conversation with one of us (SW) in 1980. At the time of the publication of Eigenmann \& Myers (1929) and the cataloging of this specimen at USNM, Myers had not seen Miranda Ribeiro (1908). Furthermore Myers in 1980 agreed with us that USNM 92955 is the holotype of $C$. iporangae. Based on the accession papers by Myers there is a notation in the USNM catalog that this specimen is a paratype. Myers had USNM 92955 specimen when he revised Eigenmann's manuscript for publication in 1929 and kept the fish in his personal fish collections until he donated it to the USNM in 1933. The length of the specimen cited in Eigenmann \& Myers (1929), $51 \mathrm{~mm}$, is total length and agrees with the length of the holotype. This specimen was apparently not examined by L. P. Schultz.

Material examined. Lectotype. NMW 56534: 1, male, 47.5 mm SL, Brazil, Rio de Janeiro State, "Bäche in der Nähe von Rio de Janeiro, rio dos Macacos" (rio Macacu, a tributary to Baía de Guanabara on northeastern shore). Paralectotype. NMW 56534: 1, female, $41.0 \mathrm{~mm} \mathrm{SL}$, same data as lectotype. Topotypes from rio Macacu, Rio de Janeiro. MZUSP 14667, 13, young to juveniles, 19.0-30.0 mm SL, rio Guapiaçu, tributary of rio Macacu, near Cachoeiras de Macacu, R. M. C. Castro, 14 May 1977; MZUSP 14668, 7, males, SL 35.0-40.7 mm SL; MZUSP 14669, 13, young to small adults 12.5-37.7 mm SL; MZUSP 26895, 41, young to juveniles, 13.1-26.9 mm SL, small tributary of rio Macacu about 1-2 km from town of Cachoeiras de Macacu, S. Weitzman, C. A. Gonçalves de Cruz and O. L. Peixoto, 27 Nov. 1979; USNM 249896, 17, young to small adults, 22.0-35.4 mm SL; USNM 254255, 40, young-small adults, SL 12.0-30.8 mm. Holotype of Coelurichthys iporangae. USNM 92955, adult male with well-developed caudal organ, 37.2 mm SL, Brazil, São Paulo, "Ribeirão das Pedras, Iporanga”, rio Ribeira de Iguape system, approximately $24^{\circ} 36^{\prime} \mathrm{S} 48^{\circ} 34^{\prime} \mathrm{W}$. Topotypes. FMNH 54886, 7, young to small adult, 17.4 to $36.4 \mathrm{~mm}$ SL, Brazil, São Paulo, Iporanga, rio Ribeira de Iguape. Non-types. All collected in Brazil. Bahia State, município de Prado. USNM 279875, 6, young to immatures, 18.8-25.0 mm SL, first stream of rio Caí on dirt road between Cumuruxatiba and Itamaraju, stream locally called rio do Sul, $17^{\circ} 00^{\prime}$ 'S $39^{\circ} 12^{\prime} \mathrm{W}$; MZUSP 53278, 5, young to immatures, 17.1$23.2 \mathrm{~mm}$ SL; USNM 279874, 1, immature, $16.5 \mathrm{~mm}$ SL, $17^{\circ} 01^{\prime} \mathrm{S}$ $39^{\circ} 12^{\prime} \mathrm{W}$; MZUSP 53279, 1, immature, 23.9 mm SL; MZUSP 28814, 3 , immatures, $15.4-22.2 \mathrm{~mm} \mathrm{SL}$, fourth stream flowing east at $26 \mathrm{~km}$ on dirt road north from Prado, rio Japurá, $17^{\circ} 10^{\prime} \mathrm{S} 39^{\circ} 14^{\prime} \mathrm{W}$; MZUSP 28813, 26, young to small adults, 18.1-29.8 mm SL, stream $18 \mathrm{~km}$ north from Prado on road to Cumuruxatiba, $17^{\circ} 10^{\prime}$ S $39^{\circ} 14^{\prime}$ 'W; USNM 276549, 24, young to small adults, 17.4-33.1 mm SL; USNM 276550, 2, young adult female and male, $24.2-28.6 \mathrm{~mm}$ SL respectively; USNM 276548, 11, immatures to small adults, SL 19.3-27.7 mm SL. MUSP 28812, 11, immatures to small adults, small stream about $5 \mathrm{~km}$ north of Prado, on road to Cumuruxatiba, $17^{\circ} 18^{\prime} \mathrm{S} 39^{\circ} 14^{\prime} \mathrm{W}$; USNM
249895, 7, immatures to small adults, 24.9-32.0 mm SL, rio Jacurucu at Prado, $17^{\circ} 21^{\prime}$ S $39^{\circ} 13^{\prime} \mathrm{W}$; USNM 313657, 1, c\&s, mature male, SL $35.4 \mathrm{~mm}$. Following lots collected in Espírito Santo State. USNM 254257, 20 immatures, 21.7-31.6 mm SL, rio Itaúnas at Itaúnas, $18^{\circ} 26^{\prime}$ 'S 3940’W; MZUSP 26898, 17, immatures to small adults, 20.5-33.0 mm SL; MNRJ 5675, ribeirão do Engano, vale do Itaúnas, Instituto Oswaldo Cruz; MNRJ 5679, 82, immatures to adults, 18.241.3 mm SL; MNRJ 10853, 1, immature, SL 24.6 mm, rio Barra Seca, between Linhares and São Mateus, approximately $19^{\circ} 02^{\prime}$ S $40^{\circ} 05^{\prime} \mathrm{W}$; MNRJ 10855, 22, young to adults, 19.5-36.5 mm SL, município de Linhares, córrego Chumbado on road between Linhares and São Mateus; MZUSP 26894, 13, immatures to adults, 25.3-42.2 mm SL município de Linhares, Reserva Florestal da Companhia do Vale do Rio Doce; USNM 249885, 11, immatures to adults, 23.2-41.2 mm SL; USNM 313656, 2, c\&s, male, 41.2 mm SL, female, 26.4 mm SL; USNM 249891, 25, immatures to adults, 22.4-24.8 mm SL MZUSP 26893, 2, adults, female, $28.4 \mathrm{~mm}$ SL and male 28.5 mm SL; USNM 313655, 2, c\&s, immature female, adult male, 27.3-31.2 mm SL respectively; USNM 279873, immatures 7, 22.4-31.7 mm SL, blackwater creek in Reserva Florestal da Companhia do Vale do Rio Doce; MNRJ 10854, 20, immatures to small adults, 22.5-34.7 mm SL, Serra, town north of Vitória, 2008'S, 40¹8’W; FMNH 15004, 15005, 15006, 3, maturing to adult males, 31.5-36.6 mm SL, Muniz Freire, sandy rocky clearwater stream one mile below town, a tributary to rio Itapemirim, approximately $20^{\circ} 28^{\prime} \mathrm{S} 41^{\circ} 24^{\prime} \mathrm{W}$; FMNH 54885 , 6, maturing to adult males, 30.5-39.0 mm SL. Following lots collected in Rio de Janeiro State. See also lectotype, paralectotype and topotypes above. USNM 249884, 4 immatures, 26.6-32.0 mm SL, small stream tributary to rio Macaé, adjacent to ruins of fazenda Torreão, 22¹6'S 4203’W; MZUSP 26905, 4, small adults, 28.930.5 mm SL; USNM 249878, 51, immatures to fully mature adult females, males, 18.5-25.9 mm SL, município de Saquarema, small stream, rio Jundiá tributary to lagoa de Saquarema, on road Amaral Peixoto between Sampaio Correia and Bacaxá, 2251'S 42³4’W; MZUSP 26903, 51, young to mature adults, 16.8-22.6 mm SL; MNRJ 26619, 51, young to mature adults, 18.5-25.4 mm SL; USNM 249898, 6 immatures, 22.2-26.4 mm SL, município de Saquarema, rio Mato Grosso into lagoa Saquarema, $5 \mathrm{~km}$ east of Sampaio Correa, 2251'S $42^{\circ} 35^{\prime} \mathrm{W}$; USNM 257199, 1, adult female, $36.1 \mathrm{~mm}$ SL, aquarium fish grown up in aquarium; USNM 249877, 50 immatures, 13.7-33.2 mm SL, município de Saquarema, rio Seco, tributary to lagoa de Saquarema, along road Amaral Peixoto between Sampaio Correia and Bacaxá, 2251'S 42³2'W, MZUSP 26907, 50 immatures, young to mature adults, 16.3-28.5 mm SL; USNM 249875, 2, adult female, adult male, 29.0-39.3 mm SL respectively, município de Saquarema, rio do Mato Grosso, tributary to rio Roncador which flows to lagoa Saquarema, 2253’S 4244’W; MZUSP 26904, 3, adults, 30.0-38.5 mm SL; USNM 249900, 33, young to adults, 17.9-34.4 mm SL, município de Saquarema, small tributary of rio Fundo, about $1 \mathrm{~km}$ from town of Itapeba, near Maricá, 2254’S 4248’ W. The following lots have only "general" locality information but are cited here because they were referred to by Schultz (1959: 112, USNM 94147 and USNM 177701) or were used by Myers to identify species in the aquarium trade and for publication of scientific names in Innes (1935 and later editions), USNM 94147 and USNM 129922; USNM 94147 , 3, two females, one male, 29.4-40.5 mm SL, vicinity of Rio de Janeiro; USNM 129922, 1, adult male, 32.2 mm SL; USNM 177701, 39,young to adults, 19.4-33.1 mm SL, Rio de Janeiro to Macaé; USNM 249889, 2 immatures, 28.5-34.7 mm SL, município de Nova Iguaçu, Tinguá, $22^{\circ} 41^{\prime} \mathrm{S} 43^{\circ} 25$ 'W; USNM 254256, 10, small adults to adults, 27.134.2 mm SL; MZUSP 19501, 1, adult male, SL 30.8 mm, município de Itaguaí, old road between cities of São Paulo and Rio de Janeiro at 
km 48; MZUSP 19334, 5, small adults to adults, 25.7-35.3 mm SL,

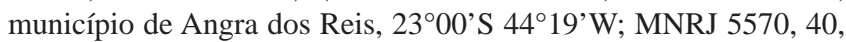
young to medium sized adults, 17.4-41.4 mm SL, município de Angra dos Reis, rio Ariró Pequeno; USNM 249874, 67, young- small adults, 24.3-35.0 mm SL, município de Angra dos Reis, rio da Areia, first small tributary to rio Jurumirim on right side of road BR 155, northeast

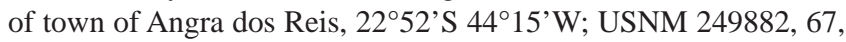
young-adults, 21.2-46.3 mm SL; MZUSP 26900, 67, young to small adults, 23.0-31.2 mm SL. Following lots collected in São Paulo State. Município de Ubatuba: USNM 249883, 48 immatures to large adults, SL 24.1-50.2 mm, rio Puruba, a small north branch about $5 \mathrm{~km}$ from

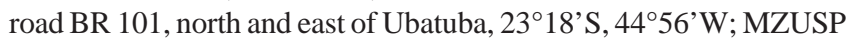
26901, immatures-medium adults 23.9-33.5 mm SL. USNM 249872, 15, immatures, 21.6-29.7 mm SL, small tributary of rio Itamambuca, about $3 \mathrm{~km}$ from road BR 101, 2323’S 4502’W; MZUSP 26901, immatures-medium adults 23.9-33.5 mm SL; MZUSP 20462, 5, juveniles, 24.7-28.5 mm SL, valley between Jardim Acaraú and road BR 101, approximately $23^{\circ} 26^{\prime} \mathrm{S} 45^{\circ} 05^{\prime} \mathrm{W}$; MZUSP 26896, 9, immatures to small adults, SL 20.4-31.5 mm; MZUSP 26897, 4, young to small adult, 12.9-32.2 mm SL; USNM 249873, 25 immatures to adults, SL $25.0-47.0 \mathrm{~mm}$ SL, south branch of rio Tavares, rio

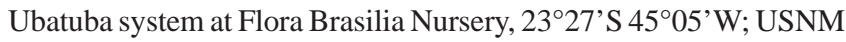
249876, 7 immatures to small adults, 30.5-41.0 mm SL, rio do Cemitério, tributary to rio Ubatuba, $23^{\circ} 25^{\prime} \mathrm{S} 45^{\circ} 07^{\prime} \mathrm{W}$; USNM 313675, 2, adult-large adult, c\&s, 1 female, 1 male, 37.2-57.3 mm SL; USNM 249879, 8 immatures to adults, 33.4-51.0 mm SL; USNM 254261, 8, adults to large adults, 34.4-60.9 mm SL, rio Silva, a tributary to rio Ubatuba along road between Ubatuba and Taubaté, $23^{\circ} 23^{\prime} \mathrm{S}$ $45^{\circ} 07^{\prime} \mathrm{W}$; USNM 313671, 2, adult to large adults, c\&s, 1 female, 1 male, 47.4-58.2 mm SL; MZUSP 26899, 10, adults-large adults, 42.0$61.0 \mathrm{~mm}$ SL; USNM 249880, adult to large adults 1 female, 1 male, 46.8-60.6 mm SL; MZUSP 19820, 02, adults, 38.1-48.9 mm SL, ribeirão Ipiranguinha; MZUSP 26909, 2, immature to small adult, 20.8-29.4 mm SL, stream on right side of the mouth of rio da Lagoa, Itaquá; USNM 326812, immature to adults 3, 36.0-48.0 mm SL, rio Indaiá, Fazenda Agricola Florestal Capricórnio Ltda. Município de Cananéia on road SP 193 km 56.:USNM 326748, immatures to adults 8, 28-43.3 mm SL; MZUSP 53280, immatures to adults 8, 31.0-42.3 mm SL. Município de Caraguatatuba: USNM 249881, 6, small adults to medium adults, 31.7- $48.8 \mathrm{~mm}$ SL, rio Escuro, 2328'S 4512' W; MZUSP 26906, 8, adults, 29.9 mm-44.1 mm SL; USNM 313684, 6, young to small adults, 24.2-32.1 mm SL, nameless stream $2.6 \mathrm{~km}$ up a dirt road from a point on road SP $5517 \mathrm{~km}$ south of town of Ubatuba, 2330'S 4512'W; MZUSP 53281 3, medium adults, 32.640.7 mm SL, rio de Ouro, Reserva Florestal Município de Bertioga: USNM 362366, 30, young to adults, 21.3-45.7 mm SL, município de Bertioga, approximately $10 \mathrm{~km}$ north of town of Bertioga on road SP 98 between Bertioga and Mogi das Cruzes, an unnamed stream, 234'ㅇ 4605'W; MZUSP 53282, 43, young-adults, 21.7-38.8 mm SL; FMNH 54887, 1, developing male, 37.8 mm SL. Município de Santos: Raiz da Serra, creek at base of mountains approximately 19 km from Santos, approximately 2350'S 46²3'W; CAS(SU) 33869, 18, young to developing males, 17.4-31.4 mm SL; USNM 249887, 2, females, 39.4-48.8 mm SL, rio Biguá near Biguá, approximately $24^{\circ} 15^{\prime}$ 'S $47^{\circ} 31$ 'W; USNM 249888, adults to large adults, 37.5-57.3 mm SL; USNM 254276, 2, adult female, adult male, 32.8-43.2 mm SL. Município de Iguape: ribeirão da Fazenda Cantagalo, Juquiá, approximately $24^{\circ} 19^{\prime} \mathrm{S} 47^{\circ} 36^{\prime} \mathrm{W}$; MZUSP 20218, 6, young to adults, 20.0-46.3 mm SL; MZUSP 53283, 4, adults, 34.2 mm,48.3 mm SL, ribeirão da Fazenda Poço Grande, Juquiá; USNM 254260, 3, adult males, 39.4-44.6 mm SL, Iguape, approximately 2443'S 47³3’ W. Following lots collected in Paraná State, município de Morretes (except where noted). USNM 177820, immatures 3, 23.5-27.8 mm SL, Morretes, on rio Marumbi, tributary of rio Nhundiaquara, $25^{\circ} 30^{\prime} \mathrm{S}$ $48^{\circ} 50^{\prime} \mathrm{W}$. USNM 249897, immatures to adults 4, 21.0-46.5 mm SL, rio Nhundiaquara at Morretes, 25²9'S 4849’W; USNM 257114, immatures to adults 6, 24.0-41.0 mm SL; USNM 236089, immature to adult 2, 34.3-45.8 mm SL, c\&s; USNM 257198, immature, 29 mm SL and adult (tail removed for histology, SL not recorded); USNM 249886, adults 2, 34.6-37.8 mm SL; MZUSP 40281, immatures to adults 28, 20.5-35.5 mm SL. MZUSP 53284, immatures to adults 21, 16-46.8 mm SL, município Porto de Cima, rio São João at first large bridge east of São João on road between BR 116 northeast of Curitiba and Paranaguá, 2523'S 4850'W. MZUSP 53285, immatures to adults, 22.5-43.0 mm SL, rio Sagrado east of Morretes, 253's $48^{\circ} 46^{\prime} \mathrm{W}$. Following lots collected rio Nhundiaquara, opposite and just downstream of Hotel Nhundiaquara, USNM 249890, 6 adults, 32.5-48.5 mm SL; USNM 249894, adults 2, 38.5-44.8 mm SL; USNM 257115, adults 9, 30.8-49.8 mm SL. Following lots from state of Paraná State, MZUSP 17838, immatures to adults 16, 15.3$24.5 \mathrm{~mm}$ SL, rio Iraí, $6 \mathrm{~km}$ east of Curitiba; USNM 270645, immatures to adults $28,20.0-45.3 \mathrm{~mm}$ SL, rio Iraí, tributary of rio Iguaçu along road BR-425 east of Curitiba. Unnamed blackwater stream crossing road "Elísio Pereira Alves Filho, about 15 km from road BR-227, southwest of Paranaguá, 2540'S 48³3’W. USNM 306378, immatures to adults, 62, 14.5-40.8 mm SL; MZUSP 40228, immatures to adults $62,14.3-38.2 \mathrm{~mm}$ SL. Ribeirão Amola Faca, tributary to rio Iguaçu, near Balsa Nova in fazenda Lara Maria, USNM 326811, 4 immatures to adults, SL 30.0-46.5 mm SL Note: field photo made of largest specimen; MZUSP 53286, 6 adults, 38.0-45.6 mm SL. Serrinha a small community between the towns of Contenda and Lapa, 1-2 km north of road BR-476, extending southwest from Curitiba. USNM 326810, 72 immatures to adults, 21.7-43.0 mm SL; MZUSP 53287, 71 immatures to adults, $19.5-44.4 \mathrm{~mm}$ SL. Following lots collected in Santa Catarina State. MNRJ 6004, immatures 13, 21.5-32.5 mm SL, unnamed tributary of rio Itapocuzinho, Guará Mirim; MNRJ 3760, immatures to adults 6, 37.0-55.0 mm SL, Joinville, date unknown. Rio Cubatão near Joinville, USNM 249893, immatures to adults 25, SL 16.3-51.3 mm; MZUSP 53288, immatures to adults 10, 32.0$45.0 \mathrm{~mm}$ SL. Rio Pique, Morro Cortado, off BR 101 at Meleiro near Limeira: USNM 254269, 4, 21.4-29.8 mm SL; USNM 249892, 10, 17.6-24.3 mm SL; MZUSP 19871, 9, 18.3-22.4 mm SL. Rio Jordão at Siderópolis, $28^{\circ} 38^{\prime}$ 'S $49^{\circ} 27^{\prime} \mathrm{W}$; USNM 249899 , immatures to adults 24, 15.8-46.6 mm SL and MZUSP 26902, immature to adults 24, 17.6-44.5 mm SL. Rio Faxinalzinho at Mãe dos Homens, near Praia Grande, approximately $29^{\circ} 15^{\prime}$ 'S 5006’W, USNM 279877, 1 adult 1 , 44.0 mm SL; MZUSP 53289, immature 1, 32.2 mm SL; MCP 13766, immature 1, $31.0 \mathrm{~mm}$ SL. Arroio Lindo on road BR-101, unnamed tributary of rio Cubatão, Joinville: USNM 326737, immatures to adults 3, 32.7-44.2 mm SL; USNM 326738, immature 1, 35.0 mm SL; MZUSP 53290, immatures to adults 3, 30.0-45.8 mm; MCP 21698, immatures 2, 36.4-39.0 mm SL. Unnamed stream tributary to rio Itapocu at Corupá: USNM 279876, immatures to adults 4, 34.351.0 mm SL; MZUSP 53291, immatures to adults 4, 27.5-48.3 mm SL; MCP 216699, immatures to adults 3, SL 22.0-46.3 mm SL Município de Praia Grande, a tributary of rio Grande about $3 \mathrm{~km}$ from Praia Grande: USNM 362362, immatures to adults 10, 27.5$42.7 \mathrm{~mm}$ SL; MZUSP 53292, immatures to adults 10, 28.8-38.0 mm SL. Município de Praia Grande 29²14’S 5001’W, rio Canoas, 8 km from Praia Grande: USNM 326747, 42 immatures to adults, 27.845.0 mm SL,; MZUSP 53293, immatures to adults, 42, 24.042 .5 mm SL; MCP 21701, immatures to adults 42, 25.3-48.0 mm SL; Rio Canoas 13 km above Praia Grande: USNM 326743, immatures 4, 30.0-37.2 mm SL; MZUSP 53294, immatures 3, SL 30.0-36.0 mm; 
MCP 21699, immatures 3, 29.8-33.5 mm SL. Following lots collected in Rio Grande do Sul State. MCP 10145, immatures 10, 16.3-20.0 mm SL, from lagoa Emboaba, Tramandaí. MAPA 2126, immatures to adult 8, 18.2-35.7 mm SL, from arroio Água Parada, Maquiné, tributary to rio Maquiné near town of Maquiné approximately $29^{\circ} 40^{\prime} \mathrm{S} 50^{\circ} 12^{\prime} \mathrm{W}$ : USNM 326746, immatures-adults 5, SL 27.5-45.3 mm SL; MZUSP 53295, immatures to adults 4, 31.0-41.0 mm SL; MCP 21702, immatures to adults 4, 30.8-41.5 mm SL. Rio Pinheiro above Maquiné: USNM 326745, immatures to adults 9, 28.8-49.5 mm SL; MZUSP 53296, immatures to adults 9, SL 33.4-54.2 mm; MCP 21703, immatures to adults 8, 33.0-52.0 mm SL, arroio Sanga do Icó tributary of rio Maquiné, about $2 \mathrm{~km}$ from town of Barra do Ouro,: USNM 326744, immatures to adults 9, 26.5-43.0 mm SL; MZUSP 53297, immatures to adults 9, 23.5-39.5 mm SL; MCP 21704, immatures to adults 9, 27.0-35.5 mm SL. Rio Três Pinheiros 8 km from road BR101 near Itati $29^{\circ} 32^{\prime} \mathrm{S} 50^{\circ} 06^{\prime} \mathrm{W}$, rio Três Forquilhas drainage: USNM 326740, immatures 3, 16.0-34.0 mm SL; MZUSP 53298, immatures 4, SL 14.7-30.0 mm; MCP 21705, immatures 4, 17.0-35.2 mm SL. Rio Mitmann in Vila Nova, about 10 km from road BR-101, rio Três Forquilhas drainage: USNM 326739, immatures-adults 21, 25.5-45.3 mm SL; MZUSP 53299, immatures to adults 20, 25.0-43.3 mm SL; MCP 21706, immatures to adults 21, 25.7-45.5 mm SL. município de Três Cachoeiras, rio das Pacas near Morro Azul 29²4'S 4957’ W: USNM 326736, immatures-adults 25, 15.7-33.5 mm SL; MZUSP 53300, immatures to adults 26, 19.0-35.6 mm SL; MCP 21707, immatures to adults 26, 16.8-36.0 mm SL. Município de Torres, rio dos Mengue between Morro Azul and Rua Nova 29¹7'S 4955'W: USNM 326742, immatures to adults 9, 24.5-42.5 mm SL; MZUSP 53301, immatures to adults 9, 20.5-36.7 mm SL; MCP 21708, immatures to adults 9, 20.3-38.0 mm SL. Canal between lagoa da Emboaba and lagoa Emboabinha on road between Tramandaí and Osório: USNM 326741, immatures-adults 27, 16.3-33.5 mm SL; MZUSP 53302, immatures to adults 24, 17.5-35.6 mm SL; MCP 21708, immatures to adults 24, 17.5- $41.3 \mathrm{~mm}$ SL.

\section{Phylogenetic biogeography}

The cladogram depicting the phylogenetic relationships of the genera and species of the group (Fig. 2) essentially confirms the results expressed in Menezes et al. (2008), the only difference being the lack of a sister group clade including Mimagoniates rheocharis and M. microlepis in the cladogram herein included. The conclusions concerning the evolutionary history and present distribution of Lophiobrycon, Glandulocauda and Mimagoniates and their respective species in that publication are here accepted and not repeated.

\section{Comments on conservation and ecology of the Glandulocaudinae}

Most species of the Glandulocaudinae are forest fishes and are subject to the usual ecological constraints affecting such fish species. Reports of $G$. caerulea up to very recently, were based on only the type specimens collected by John D. Haseman near Serrinha; see Eigenmann (1911a: 307). The specimens reported by Ingenito et al. (2004) were collected mainly in creeks surrounded by dense rainforest vegetation in the municípios of Balsa Nova, Lapa, and Quatro Barras east of Curitiba, isolated from the type locality but still belonging to the upper rio Iguaçu basin. We agree with these authors that $G$. caerulea might not be as rare as indicated by Rosa \& Menezes (1996) and is more widespread than our previous evidence indicated, but apparently restricted to patches where vegetation is still abundant. However it was considered threatened in Brazil (Duboc \& Menezes, 2008, as Glandulocauda melanopleura). We can even conceive of a more contiguous distribution in the past which was interrupted with the recent growth of Curitiba and smaller cities nearby.

Mimagoniates microlepis is widely distributed in the coastal streams of eastern and southern Brazil and appears to be in no danger of extinction. The other species in the genus, however, are more restricted with their habitat limited to black, acid water forest streams. For example, Mimagoniates inequalis occurs in lower elevation streams of the Guaíba basin in Rio Grande do Sul and northeastern Uruguay. Although it does well in clear black acid waters in areas of good secondary forest growth one of us (Menezes) failed to collect $M$. inequalis from various streams flowing into the Guaíba basin where it was formerly common. These areas have recently become more densely populated by humans, with apparent increases of pollution levels and of forest and native vegetation cover essential for the maintenance of black acid waters necessary for $M$. inequalis. Other species, for example Mimagoniates sylvicola, $M$. rheocharis, and $M$. lateralis are either ecologically restricted and/or now have such a narrow geographical distribution that habitat disturbance could lead to their extinction. They are included in the Red Book of the Brazilian fauna threatened with extinction (Rosa \& Lima, 2008). One species, Mimagoniates barberi is known from limited collections and little is known about its habitat. However, Jeffrey N. Taylor stated that this species is found in clear black to clear brown waters (J. Taylor, pers. comm.). However, successful attempts to breed this species, from specimens obtained from Paraguay, "50 miles from Asunción", show that although brown or black waters are not necessary for successful breeding and raising of the young, the species does require water of low mineral content, with a $\mathrm{pH}$ of 5.5-6.5 and a temperature of about $22-25^{\circ} \mathrm{C}$. These breeding efforts suggest that this species would be very sensitive to pollution of any kind, agricultural, residential or industrial.

Mimagoniates pulcher is known from only one collection taken in 1934 from the northern region of the Pantanal. Its precise locality remains unknown and despite two attempts to recollect this species we failed to find it. The fish may now be extinct from habitat alteration due to soy bean culture and/ or repeated clearing of vegetation over by fire.

Our field experiences corroborates our laboratory experiences with $M$. barberi and indicates that probably all species of the tribe require clear or in some cases black acid water with low mineral content for successful reproduction. Approximately 5.5 to $6.0 \mathrm{pH}$ waters may be best for the blackwater species and a 6.0-6.5 $\mathrm{pH}$ for clear water species. Streams, ponds and lakes that have water with a low mineral content and a somewhat acid $\mathrm{pH}$ are ordinarily poorly buffered. 
Thus pollution easily alters the chemical nature of such waters with quick and devastating effect on the native aquatic fauna and flora. Agricultural pollution by use of chemical pesticides and/or fertilizers can alter the chemical properties of ground water and therefore that of the adjacent streams they support. We therefore suspect that all species of the Glandulocaudinae are subject to local extinction from industrial, agricultural, or domestic pollution.

\section{Acknowledgements}

Much of the field work in Brazil and laboratory research in São Paulo and Washington D.C. for this study was supported by the Neotropical Lowland Research Program (NLRP), of the International Environmental Science Program of the Smithsonian Institution. We thank the late Clifford Evans, W. Ronald Heyer, and Richard P. Vari, former principal investigators of the NLRP for their support and encouragement. The Bacon Fund, Smithsonian Institution, provided funds for part of the field work in Rio Grande do Sul and Santa Catarina. The Conselho Nacional de Desenvolvimento Científico e Tecnológico (CNPq), Brazil also provided travel and per diem funds for laboratory research in São Paulo and Washington, D. C. to NAM. Field research was supported in part by a grant (\# 1797) from the National Geographic Society. Herbert R. Axelrod supported this research in part by providing payments for articles published in Tropical Fish Hobyist, TFH Publications Inc. New Jersey from 1995-1998. We are indebted to the Herbert R. and Evelyn Axelrod Revolving Chair of the Division of Fishes, National Museum of Natural History, Smithsonian Institution, for providing funds in support of this research. Many drawings were paid for by the Department of Vertebrate Zoology, Smithsonian Institution. Rosario LaCorte provided some of the color photographs of live fishes used in this publication. John R. Burns and Robert Javonillo provided information concerning and illustrations of the club cells of the male caudal glands of the three genera of the Glandulocaudinae.

The following individuals and institutions contributed much support for this study sometimes via loans of specimens, support for collecting efforts and often by personal collecting efforts or in some cases by all three: Donn E. Rosen, Carl J. Ferraris, Gareth Nelson, and Norma Feinberg (all AMNH); Eugenia B. Böhlke, James E. Böhlke, William Smith-Vaniz and Scott A. Schaefer (all ANSP); Gordon Howes, Peter Whitehead, Alwyne Wheeler, and especially P. Humphry Greenwood and Darrell Siebert (BMNH); William Eschmeyer and Pearl Sonoda (CAS); Carlos A. Gonçalves da Cruz and Oswaldo L. Peixoto (UFRRJ); Barry Chernoff (FMNH); Paulo Buckup (MNRJ); Carlos A. S. de Lucena, Zilda Margarete S. de Lucena, and Roberto E. Reis, (MCP); Gustavo W. Nunan (MNRJ); Heraldo A. Britski, Paulo E. Vanzolini and José Lima de Figueiredo (MZUSP); Harald Ahnelt and especially Barbara Herzig (NMW); Ierecê Rosa and Ricardo Rosa (UFPB); Leda F. A. Jardim and Luiz R. Malabarba (UFRGS); Julio C. Garavello (UFSC); Reeve M. Bailey, Sara V. Fink, William L. Fink, and
Gerald R. Smith (UMMZ); Ricardo M. Corrêa e Castro (USPRP). Sara V. Fink (UMMZ) prepared Figs.15-18, 32-35, 39-41, 56-59, 66-69, 73-76, and 81-87, Bonnie Bower-Dennis Figs. 24-28, Diane Mahaney Figs. 47 and 51, Tamara Clark Figs. 48-50, Kelly Mautari (MZUSP) Figs. 6 and 7, Eduardo Baena (MZUSP) Fig. 8, and Alexandre C. Ribeiro (MZUSP) Figs. 3-5. Field assistance was provided by N. Labbish Chao (FUA), Thomas Litz (Attenweiler, Germany), Luiz E. Macedo Cardoso (Rio de Janeiro), Rosario LaCorte (Berkeley Hills, New Jersey), Viggo Schultz (Porto Alegre), Alicido Witeck (Taim, Rio Grande do Sul), especially Marilyn Weitzman (USNM) and Luiz Pinni Netto (São Paulo). Anna L. Weitzman and Tom Orrell (USNM) and José L. O. Birindelli, André Mendonça and Eduardo Baena (MZUSP) provided computer assistance. Laboratory assistance in preparation of radiographs and propagation of glandulocaudines and other characids were provided by Antonio Machado-Allison, Lynn Norrod, and especially Lisa Palmer. Sandra Raredon, Ray Carthy, Jeffrey Clayton, Tom Orrell, and particularly Lisa Palmer provided curatorial assistance. Thomas A. Munroe, Marilyn Weitzman and especially Flávio C. T. Lima (MZUSP) provided constructive comments on all or parts of the manuscript. Special thanks are due to Richard P. Vari (USNM) for reviewing the entire manuscript and offering valuable comments, suggestions and additions.

\section{Literature Cited}

Axelrod, H. A. 1958. In passing. Tropical Fish Hobbyist, 7(4): 4-25. Axelrod, H. A.1959. In passing. Tropical Fish Hobbyist, 7(5): 24-40. Böhlke, J. E. 1954. Studies on fishes of the family Characidae. $N^{0} 7$. A new genus and species of glandulocaudine characids from central Brazil. Stanford Ichthyological Bulletin, 4(4): 265-274.

Böhlke, J. E. 1958. Studies of fishes of the family Characidae. $\mathrm{N}^{\mathrm{o}}$ 14. A report on several extensive recent collections from Ecuador. Proceedings of the Academy of Natural Sciences of Philadelphia, 110: 1-121.

Britski, H. A., K. Z. de Silimon \& B. S. Lopes. 2007. Peixes do Pantanal. Manual de identificação, 2 ed. rev. ampl., Brasília, Embrapa Informação Tecnológica, 227p.

Buckup, P. A., N. A. Menezes \& M. S. Ghazzi. 2007. Catálogo das espécies de peixes de água doce do Brasil. Rio de Janeiro, Museu Nacional, 195p.

Castro, R. M. C., A. C. Ribeiro, R. C. Benine \& A. L. A. Melo. 2003. Lophiobrycon weitzmani, a new genus and species of glandulocaudine fish (Characiformes: Characidae) from the rio Grande drainage, upper rio Paraná system, southeastern Brazil. Neotropical Ichthyology, 1(1): 11-9.

Costa, W. J. E. M. 1987. Feeding habits of a fish community in a tropical stream, rio Mato Grosso, Brazil. Studies on Neotropical Fauna and Environment, 22(3): 145-153.

Duboc, L. F. \& N. A. Menezes. 2008. Glandulocauda melanopleura Eigenmann, 1911. Pp. 63-65. In: Machado, A. B. M., G. M. Drummond \& A. P. Paglia (Eds.). Livro vermelho da fauna brasileira ameaçada de extinção. Brasília, MMA; Belo Horizonte, Fundação Biodiversitas, v. 2, 1420p.

Eigenmann, C. H. 1910. Catalog of the freshwater fishes of tropical and south temperate America. Report of the Princeton University Expedition to Patagonia, 1896-1899, 3(4): 375-511. 
Eigenmann, C. H. 1911a. The localities at which Mr. John D. Haseman made collections. Annals of the Carnegie Museum, 7(3-4): 299-314.

Eigenmann, C. H. 1911b. III. New characins in the collections of the Carnegie Museum. Annals of the Carnegie Museum, 8(1): 164-181.

Eigenmann, C. H. 1914. Some results from studies of South American fishes, II. The Glandulocaudinae (a new subfamily of characid fishes with innate potentialities for sexual dimorphism). Indiana University Studies, 20: 32-35.

Eigenmann, C. H. 1921. The American Characidae. Memoirs of the Museum of Comparative Zoology, 43(1): 209-310.

Eigenmann, C. H. \& R. S. Eigenmann. 1891. A catalog of the freshwater fishes of South America. Proceedings of the United States National Museum, 14: 1-81.

Eigenmann, C. H. \& G. S. Myers. 1929. The American Characidae, 5. Memoirs of the Museum of Comparative Zoology (Harvard College), 43(5): 429-515 plus supplement pages 516-558, plates 57, 70-74, 81-83, 94.

Ellis, M. D. 1911. On the species of Hasemania, Hyphessobrycon, and Hemigrammus collected by J. D. Haseman for the Carnegie Museum. Annals of the Carnegie Museum, 8(1): 148-163.

Eschmeyer, W. N. 1990. Catalog of the Genera of Fishes. San Francisco, California Academy of Sciences, 697p.

Fink, W. L. \& S. H. Weitzman. 1974. The so-called cheirodontin fishes of Central America with descriptions of two new species (Pisces: Characidae). Smithsonian Contributions to Zoology, (172): 1-46.

Fowler, H. W. 1948. Os peixes de água doce do Brasil. Arquivos de Zoologia do Estado de São Paulo, 6: 1-204.

Fowler, H. W. 1951. Os peixes de água doce do Brasil. Arquivos de Zoologia do Estado de São Paulo, 6: 405-628.

Géry, J. 1964. Glandulocauda terofali sp. nov., un nouveau poisson characoïde de la République Argentine, avec une note sur la “glande” caudale des Stevardiidi. Opuscula Zoologica, 78: 1-12.

Géry, J. 1966. A review of certain tetragonopterinae (Characoidei), with the description of two new genera. Ichthyologica, the Aquarium Journal, 37(5): 211-236.

Géry, J. 1977. Characoids of the World. New Jersey, TFH Publications, 672p.

Godoy, M. P. 1979. Rio Iguaçu, Paraná, Brasil, reconhecimento da ictiofauna, modificações ambientais e usos múltiplos dos reservatórios. Florianópolis, Eletrosul Centrais Elétricas do Sul do Brasil S.A., 33p.

Godoy, M. P. 1987. Peixes do Estado de Santa Catarina. Florianópolis, Universidade Federal de Santa Catarina, 571p.

Guimarães, I. N., L. F.Almeida-Toledo, C. Oliveira, F. Foresti \& S. A. Toledo Filho. 1995. Cytogenetic studies of three species of Glandulocaudinae (Pisces, Characiformes, Characidae). Revista Brasileira de Genética, 18: 185-189.

Henn, A. W. 1928. List of types in the collection of the Carnegie Museum on September, 1928. Annals of the Carnegie Museum, 19(4): 51-99.

Hennig, W. 1966. Phylogenetic Systematics. Urbana, University of Illinois Press, 263p.

Holly, M., H. Meinken \& A. Rachow. 1950a. Die Aquarienfische in Wort und Bild. Lieferung 73/74, Blatt.: 749-768, Stuttgart: Alfred Kernen Verlag.

Holly, M., H. Meinken \& A. Rachow.1950b. Die Aquarienfische in Wort und Bild. Lieferung 75/76, Blatt.: 769-788, Stuttgart: Alfred Kernen Verlag.

Holly, M., H. Meinken \& A. Rachow. 1950c. Die Aquarienfische in Wort und Bild. Lieferung, 79/80, Blatt.: 809-828, Stuttgart: Alfred Kernen Verlag.
Houtan, A. 1990a. (Color photograph of live Mimagoniates barberi). Characoids, Newsletter International Characin Association, Lancashire, England, 1990(4): 1-21.

Houtan, A.1990b. Mimagoniates barberi, Regan. Characoids, Newsletter International Characin Association, Lancashire, England, 1990(6): 1-21.

Hubbs, C. L. 1943. Criteria for subspecies, species and genera, as determined by researches on fishes. Annals of the New York Academy of Sciences, 44(2): 109-121.

Humphries, C. J. \& L. R. Parenti. 1986. Cladistic Biogeography. Oxford Monographs on Biogeography, 2: 1-98. Oxford, Clarendon Press.

Ibarra, M. \& D. J. Stewart. 1987. Catalogue of type specimens of Recent fishes in Field Museum of Natural History. Fieldiana Zoology (New Series), (33): 1-112.

Ingenito, L. F. S., L. F. Duboc \& V. Abilhoa. 2004. Contribuição ao conhecimento da ictiofauna da bacia do alto Rio Iguaçu, Paraná, Brasil. Arquivos de Ciências Veterinárias e Zoológicas UNIPAR, Umuarama, 7(1): 23-36.

Innes, W. T. 1935. Exotic Aquarium Fishes. Philadelphia, Innes Publishing Company, 463p.

Lampert, V. R., M. A. Azevedo \& C. B. Fialho. 2003. Hábito alimentar de Mimagoniates microlepis Steindachner, 1876 (Characidae: Glandulocaudinae) do canal de ligação entre as lagoas Emboaba e Emboabinha, Rio Grande do Sul, Brasil. Comunicações do Museu de Ciências e Tecnologia da PUCRS, Série Zoologia, 16(1): 3-16.

Langeani, F., R. M. C. Castro, O. T. Oyakawa, C. S. Pavanelli \& L. Casatti. 2007. Diversidade da ictiofauna do Alto Paraná: composição atual e perspectivas futuras. Biota Neotropica, 7(3): 181-195.

Lima, F. C. T., H. A. Bristki \& F. A. Machado. 2004. New Knodus (Ostariophysi: Characiformes: Characidae) from the upper Rio Paraguay Basin, Brazil. Copeia, 2004(3): 577-582.

López, H. S., C. C. Morgan \& M. J. Montenegro. 2002. Ichthyological ecoregions of Argentina. Probiota, (1): 1-68.

Mabee, P. 1987. Phylogenetic change and ontogenetic interpretation in the family Centrarchidae (Pisces: Perciformes). Unpublished Ph.D. Dissertation, Duke University, Durham, NC.

Machado, A. B. M., C. S. Martins \& G. M. Drummond. 2005. Lista da fauna brasileira ameaçada de extinção: incluindo as espécies quase ameaçadas e deficientes em dados. Belo Horizonte, Fundação Biodiversitas, 160p.

Maddison, W. P., M. J. Donoghue \& D. R. Maddison.1984. Outgroup comparison and parsimony. Systematic Zoology, 33: 83-103.

Malabarba, L. R. 1989. Histórico sistemático e lista comentada das espécies de peixes de água doce do sistema da laguna dos Patos, Rio Grande do Sul, Brasil. Comunicações do Museu de Ciências PUCRS, 2(8): 107-109.

Malabarba, L. R. 1998. Monophyly of the Cheirodontinae, characters and major clades (Ostariophysi: Characidae). Pp. 193-233. In: Malabarba, L. R., R. E. Reis, R. P. Vari, Z. M. S. Lucena \& C. A. S. Lucena (Eds.). Phylogeny and Classification of Neotropical Fishes. Porto Alegre, Edipucrs, 603p.

Malabarba, L. R., M. A. Azevedo \& N. A. Menezes. 2008. Mimagoniates rheocharis Menezes \& Weitzman, 1990. Pp. 7980. In: Machado, A. B. M., G. M. Drumond \& A. P. Paglia (Eds.). Livro vermelho da fauna brasileira ameaçada de extinção. Brasília, MMA; Belo Horizonte, Fundação Biodiversitas, 2: 1-907.

Malabarba, L. R. \& S. H. Weitzman. 1999. A new genus and new species of South American fishes (Teleostei: Characidae: Cheirodontinae) with a derived caudal fin, together with comments on internally inseminated cheirodontines. Proceedings of the Biological Society of Washington, 112(2): 410-432. 
Malabarba, L. R. \& S. H. Weitzman. 2000. A new genus and species of inseminating fish (Teleostei: Characidae: Cheirodontinae: Compsurini) from South America with uniquely derived caudal-fin dermal papillae. Proceedings of the Biological Society of Washington, 113(1): 269-283.

Malabarba, L. R. \& S. H. Weitzman. 2003. Description of a new genus with six new species from Southern Brazil, Uruguay and Argentina, with a discussion of a putative characid clade (Teleostei: Characiformes: Characidae). Comunicações do Museu de Ciências e Tecnologia, PUCRS, Série Zoologia, 16(1): 67-151.

Menezes, N. A. 1988. Implications of the distribution patterns of the species of Oligosarcus (Teleostei, Characidae) from Central and Southern South America. Pp.295-304. In: P. E. Vanzolini \& W. R. Heyer (Eds.). Proceedings of a workshop on neotropical distribution patterns. Rio de Janeiro, Academia Brasileira de Ciências, 448p.

Menezes, N. A. \& F. C. T. Lima. 2008. Glandulocauda melanogenys Eigenmann, 1911. Pp. 62-63. In: Machado, A. B. M., G. M. Drumond \& A. P. Paglia (Eds.). Livro vermelho da fauna brasileira ameaçada de extinção. Brasília, MMA; Belo Horizonte, Fundação Biodiversitas, 2: 1-907.

Menezes, N. A. \& S. H. Weitzman. 1990. Two new species of Mimagoniates (Teleostei: Characidae: Glandulocaudinae), their phylogeny and biogeography and a key to the glandulocaudin fishes of Brazil and Paraguay. Proceedings of the Biological Society of Washington, 103(2): 380-426.

Menezes, N. A., S. H. Weitzman, O. T. Oyakawa, F. C. T. de Lima, R. M. C. Castro \& M. J. Weitzman. 2007. Peixes de água doce da Mata Atlântica: lista preliminar de espécies e comentários sobre conservação de peixes de água doce neotropicais. São Paulo, Museu de Zoologia, Universidade de São Paulo, 408p.

Menezes, N. A., A. C. Ribeiro, S. H. Weitzman \& R. A. Torres. 2008. Biogeography of the Glandulocaudinae (Teleostei: Characiformes: Characidae) revisited: phylogenetic patterns, historical geology and genetic connectivity. Zootaxa, 1726: 33-48.

Miranda Ribeiro, A. de. 1908. Peixes da Ribeira: Resultados de excursão do Sr. Ricardo Krone, membro correspondente do Museu Nacional do Rio de Janeiro. Kosmos, Revista Artistica, Scientifica e Litteraria (Rio de Janeiro), 5(2): 5 unnumbered pages.

Miranda Ribeiro, P. de. 1955. Tipos das espécies e subspécies do Prof. Alipio de Miranda Ribeiro depositados no Museu Nacional (com uma relação dos gêneros, espécies subespécies descritos). Arquivos do Museu Nacional, 42(1): 389-417.

Mirande, J. M. 2009. Weighted parsimony phylogeny of the family Characidae (Teleostei: Characiformes). Cladistics, 25: 1-40.

Myers, G. S. 1928. The Characins. Aquatic Life and the Aquatic World, 12(7): 119, 120, 122, 134, 135.

Myers, G. S. 1952. Annual Fishes. The Aquarium Journal, 23(7): 125-141.

Myers, G. S. \& J. E. Böhlke. 1956. The Xenurobryconini, a group of minute South American characid fishes with teeth outside the mouth. Stanford Ichthyological Bulletin, 7(2): 6-12.

Nelson, K. 1964a. Behavior and morphology in the Glandulocaudine fishes (Ostariophysi, Characidae). University of California Publications in Zoology, 75(2): 59-152.

Nelson, K. 1964b. The temporal patterning of courtship behavior in the Glandulocaudine fishes (Ostariophysi, Characidae). Behavior, 14(1-2): 90-146

Nelson, K. 1964c. The evolution of a pattern of sound production associated with courtship in the characid fish Glandulocauda inequalis. Evolution, 18(4): 526-540.
Nichols, J. T. 1913. On two new characins in the American Museum. Proceedings of the Biological Society of Washington, 26: 151152.

Oyakawa, O. T. 1996. Catálogo dos tipos de peixes recentes do Museu de Zoologia da USP. I. Characiformes (Teleostei: Ostariophysi). Papéis Avulsos de Zoologia, São Paulo, 39(23): 443-507.

Oyakawa, O. T., A. Akama, K. C. Mautari \& J. C. Nolasco. 2006. Peixes de riachos da Mata Atlântica nas Unidades de Conservação do Vale do Ribeira de Iguape no Estado de São Paulo. São Paulo, Editora Neotrópica, 201p.

Pearson, N. E. 1937. The fishes of the Beni-Mamoré and Paraguay basins, and a discussion of the origin of the Paraguayan fauna. Proceedings of the California Academy of Sciences, Fourth Series, 23(8): 99-114.

Pecio, A. \& J. Rafiñski. 1994. Structure of the testes, spermatozoa and spermatozeugmata of Mimagoniates barberi Regan, 1907 (Teleostei: Characidae), an internally fertilizing, oviparous fish. Acta Zoologia, 75: 179-185.

Rachow, A. 1927. Tropical Aquariafish Catalogue. Aquarienfish IM-\& Export Co., Wandesbek (Hamburg) Germany, 35p.

Rachow, A. 1928. Handbuch der Zierfischkunde. Stuttgart: Verlag von Julius E.G. Wegner, 247p.

Regan, C. T. 1907. Description of two new characinid fishes from South America. Annals and Magazine of Natural History, ser. 7, 20: 402-403.

Reis, R. E., S. O. Kullander \& C. J. Ferraris Jr. (Eds.). 2003. Check list of the freshwater fishes of South and Central America. Porto Alegre, Edipucrs, 729p.

Ribeiro, A. C., F. C. T. Lima, C. Ricomini \& N. A. Menezes. 2006. Fishes of the Atlantic Rainforest of Boracéia: testimony of the Quaternary fault reactivation within a Neoproterozoic tectonic province in Southeastern Brazil. Ichthyological Exploration of Freshwaters, 17(2): 625-630.

Rosa, R. S. \& N. A. Menezes. 1996. Relação preliminar das espécies de peixes (Pisces, Elasmobranchii, Actinopterygii) ameaçadas no Brasil. Revista Brasileira de Zoologia, 13(3): 647-667.

Sabino, J. \& R. M. C. Castro. 1990. Alimentação, período de atividade e distribuição espacial dos peixes de um riacho da Floresta Atlântica (sudeste do Brasil). Revista Brasileira de Biologia, 50(1): 23-36.

Sant'Anna, J. M. F., M. C. de Almeida, M. R. Vicari, O. S. Shibata \& R. F. Artoni. 2006. Levantamento rápido de peixes em uma lagoa marginal do rio Imbituva, na bacia do alto rio Tibagi, Paraná, Brasil. Publicações da UEPG, Ciências Biológicas e da Saúde, Ponta Grossa, 12(1): 39-46.

Schaefer, S. A., S. H. Weitzman \& H. A. Britski. 1989. Review of the neotropical catfish genus Scoloplax (Pisces: Loricaroidea: Scoloplacidae) with comments on reductive characters in phylogenetic analysis. Proceedings of the Academy of Natural Sciences of Philadelphia, 141: 181-211.

Schultz, H. 1959. The Mimagoniates species. Tropical Fish Hobbyist, 7(10): 46-53.

Schultz, L. P. 1959. Generic status of Mimagoniates and Glandulocauda, South American characid fishes. Tropical Fish Hobbyist, 8(2): 6-10, 63, 64.

Schultze, H. \& G. Arratia. 1989. The composition of the caudal skeleton of Teleosts (Actinopterygii: Osteichthyes). Zoological Journal of the Linnean Society, 97: 189-231.

Steindachner, F. 1876a. Die Süwasserfische des südöstlichen Brasilien (III). Sitzungsberichte der kaiserliche Akademie der Wissenschaften, Wien, 74: 1-191. 
Steindachner, F. 1876b. Ichthyologische Beiträge (V.). II: Über einige neue Fischarten, insbesondere Characinen und Siluroiden aus dem Amazonenstrome. Zitzungsberichte der kaiserliche Akademie der Wissenschaften, Wien, 74: 73-167.

Sterba, G. 1987. Süsswasserfische der Welt. Leipzig, Urania-Verlag, 915p.

Stiassny, M. 1992. Atavisms, phylogenetic reversals, and the origin of evolutionary novelties. Netherlands Journal of Zoology, 42(2-3): 260-276.

Swofford, D. 1993. PAUP: phylogenetic analysis using parsimony. Version 3.1.1. Illinois Natural History Survey, Champaign , Illinois.

Torres, R. A., T. S. Motta, D. Nardino, M. L. Adam \& J. Ribeiro. 2007. Chromosomes, RAPDs and evolutonary trends of the neotropical fish Mimagoniates microlepis (Teleostei: Characidae: Glandulocaudinae) from coastal and continental regions of the Atlantic forest, southern Brazil. Acta Zoologica (Stockholm), 88: 1-7.

Travassos, H. 1951a. Catálogo dos gêneros e sub-gêneros da subordem Characoidei (Actinopterygii - Cypriniformes). Dusenia, 2(5): 341-360.

Travassos, H. 1951b. Catálogo dos gêneros e sub-gêneros da subordem Characoidei (Actinopterygii - Cypriniformes). Dusenia, 2(6): 419-434.

Travassos, H. 1952. Catálogo dos gêneros e sub-gêneros da subordem Characoidei (Actinopterygii - Cypriniformes). Dusenia, 3(2): 141-180.

Vari, R. P. \& C. Howe. 1991. Catalog of type specimens of Recent fishes in the National Museum of Natural History, Smithsonian Institution. 1. Characiformes (Teleostei, Ostariophysi). Smithsonian Contributions to Zoology, (517): 1-52.

Weitzman, S. H. 2003. Subfamily Glandulocaudinae (Characins, tetras). Pp. 222-230. In: Reis, R. E., S. O. Kullander \& C. J. Ferraris Jr. (Eds.). Check List of the Freshwater Fishes of South and Central America. Porto Alegre, Edipucrs, 729p.

Weitzman, S. H. \& S. V. Fink. 1985. Xenurobryconin phylogeny and putative pheromone pumps in glandulocaudine fishes (Teleostei: Characidae). Smithsonian Contributions to Zoology, (421): 1-121.

Weitzman, S. H., S. V. Fink, A. Machado Allison \& R. Royero. 1994. A new genus and species of Glandulocaudinae (Teleostei: Characidae) from southern Venezuela. Ichthyological Exploration of Freshwaters, 5(1): 45-64.

Weitzman, S. H. \& L. R. Malabarba. 1999. Systematics of Spintherobolus (Teleostei: Characidae: Cheirodontinae) from eastern Brazil. Ichthyological Exploration of Freshwaters, 10(1): 1-43.

Weitzman, S. H. \& N. A. Menezes. 1994. As especies de Glandulocauda e Mimagoniates, peixes glandulocaudíneos do Brasil, Paraguai e nordeste do Uruguai. Habitat, 1(1): 1-8.

Weitzman, S. H. \& N. A. Menezes. 1998. Relationships of the tribes and genera of the Glandulocaudinae (Ostariophysi: Characiformes: Characidae) with a description of a new genus, Chrysobrycon. Pp. 171-192. In: Malabarba, L. R., R. E. Reis, R. P. Vari, Z. M. S. Lucena \& C. A. S. Lucena (Eds.). Phylogeny and Classification of Neotropical Fishes. Porto Alegre, Edipucrs, 603p.

Weitzman, S. H., N. A. Menezes \& J. R. Burns. 1996a. Species of the glandulocaudine tetra tribe Glandulocaudini: the genus Mimagoniates (Part 3). Tropical Fish Hobbyist, 44(6): 195210.

Weitzman, S. H., L. Palmer, J. R. Burns \& N. A. Menezes. 1996b. Breeding and rearing species of Mimagoniates, internally fertilized tetras. (Part 2). Tropical Fish Hobbyist, 44(10): 196-205.
Weitzman, S. H., N. A. Menezes, J. R. Burns \& H-Georg Evers. 2005. Putative relationships among inseminating and externally fertilizing characids, with a description of a new genus and species of Brazilian inseminating fish bearing an anal-fin gland in males (Characiformes: Characidae). Neotropical Ichthyology, 3(3): 329-360.

Weitzman, S. H., N. A. Menezes \& M. J. Weitzman. 1988. Phylogenetic biogeography of the Glandulocaudini (Teleostei: Characiformes, Characidae) with comments on the distributions of other freshwater fishes in eastern and southeastern Brazil. Pp. 379-427. In: P. E. Vanzolini and W. R. Heyer (Eds.). Proceedings of a workshop on neotropical distribution patterns. Rio de Janeiro, Academia Brasileira de Ciências, 488p.

Weitzman, S. H., L. Palmer, J. R. Burns \& N. A. Menezes. 1996. Breeding and rearing Mimagoniates species, internally fertilized tetras. Tropical Fish Hobbyist, 44(12): 196-205.

Weitzman, S. H. \& R. P. Vari. 1988. Miniaturization in South American freshwater fishes; an overview and discussion. Proceedings of the Biological Society of Washington, 101(2): 444-465.

Wiley, E. O. 1981. Phylogenetics, the Theory and Practice of Phylogenetic Systematics. New York, John Wiley and Sons, 439p.

Zanata, A. M. \& R. P. Vari. 2005. The family Alestidae (Ostariophysi, Characiformes): A phylogenetic analysis of a trans-Atlantic clade. Zoological Journal of the Linnean Society, 145: 1-144.

Zarske, A. \& J. Géry. 2006. Beschreibung einer neuen Salmler-Gattung und zweier neuer Arten (Teleostei: Characidae) aus Peru und Brasilien. Zoologische Abhandlungen (Dresden), 55: 31-49.

Accepted March 26, 2009

Published September 30, 2009 